МIНІСТЕРСТВО ВНУТРІШНІХ СПРАВ УКРАЇНИ

ДОНЕЦЬКИЙ ДЕРЖАВНИЙ УНІВЕРСИТЕТ

ВНУТРІШНIX СПРАВ

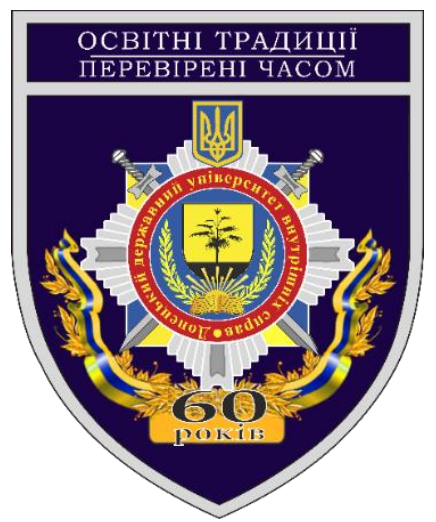

\title{
ПРАВОВИЙ ЧАСОПИС ДОНБАСУ
}

Збірник наукових праць

№ 2 (75) 2021

Виходить 4 рази на рік

Засновано в березні 1997 року

Наукове видання

включено до міжнародної наукометричної бази

«Index Copernicus International» 

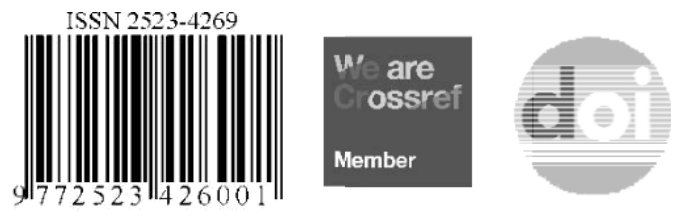

Рекомендовано до друку Вченою радою ДонДУВС

(протокол № 14 від 28.05.2021)

\section{ПРАВОВИЙ ЧАСОПИС ДОНБАСУ № 2 (75) 2021}

Виходить 4 рази на рік Засновано в березні $1997 \mathrm{p}$. Відповідно до наказу Міністерства освіти і науки України від 17.03.2020 № 409 «Про затвердження рішень Атестаційної колегії Міністерства щодо формування Переліку наукових фахових видань України від 26 лютого і 6 березня 2020 року та внесення змін до наказу Міністерства освіти і науки України від 11 липня 2019 року № 975» збірник включено до Переліку фахових видань України як друковане періодичне видання категорії «Б» у галузі юридичних наук (081 - Право)

У збірнику розглядаються загальнотеоретичні та історичні аспекти держави і права, висвітлюються актуальні питання конституційного, міжнародного, господарського, цивільного, трудового, адміністративного, фінансового, інформаційного, кримінального права, криміналістики, оперативнорозшукової діяльності Ø Відповідальність за точність поданих термінів, фактів, цитат, цифр і прізвищ несугь автори матеріалів

$\varnothing$ Редакційна колегія не завжди поділяє думку авторів

Ø Розсилається до державних установ та наукових бібліотек України

$\varnothing$ Електронна версія кожного випуску збірника безоплатно розміщується у відкритому доступі на сайті Національної бібліотеки України імені В. І. Вернадського НАН України в розділі «Наукова періодика України» та в архіві на вебсайті видання за адресою: https://ljd.dli.donetsk.ua Засновник та видавець: Донецький державний університет внугрішніх справ Свідоцтво про державну реєстрацію КВ № 22761-1 2661 ПР від 30.05.2017 p.

Адреса редакції: Дніпропетровська обл., м. Кривий Ріг, вул. Степана Тільги, 21

\section{Редакційна колегія}

Головний редактор - Бесчастний В. М., керівник Секретаріату Конституційного Суду України, доктор юридичних наук, доктор наук 3 державного управління, професор, заслужений юрист України;

заступник головного редактора - Зозуля Є. В., професор кафедри загально-правових дисциплін Донецького державного університету внутрішніх справ (далі - ДонДУВС), доктор юридичних наук, професор;

відповідальний секретар - Деревянко Б. В., провідний науковий співробітник відділу міжнародного приватного права i порівняльного правознавства Науково-дослідного інституту приватного права і підприємництва імені академіка Ф. Г. Бурчака Національної академії правових наук України, доктор юридичних наук, професор;

редактор - Рутвян О. І., завідувач редакційно-видавничого відділення відділу організації наукової роботи ДонДУВС;

илени редколегії:

Бурий В. Є. - начальник відділу кримінологічних досліджень Науковопрактичного центру 3 проблем зміцнення законності та правопорядку Генеральної прокуратури Республіки Білорусь, кандидат юридичних наук, доцент (Республіка Білорусь);

Наджафгулієв Рафіг Іслам огли - начальник кафедри адміністративної діяльності органів внутрішніх справ Академії Поліції МВС Азербайджанської Республіки, доктор філософії 3 права, доцент (Азербайджанська Республіка);

Одажіу Ю. М. - проректор Академії «Stefan cel Mare» МВС Республіки Молдова, доктор права (Республіка Молдова);

Вітвіцький С. С. - ректор ДонДУВС, доктор юридичних наук, професор, заслужений юрист України;

Волобуєв А. Ф. - професор кафедри кримінального процесу та криміналістики факультету № 1 ДонДУВС, доктор юридичних наук, професор;

Громенко Ю. О. - директор Навчально-наукового інституту права та кібербезпеки Одеського державного університету внутрішніх справ, кандидат юридичних наук, доцент;

Клемпарський М. М. - професор кафедри цивільного, трудового права та права соціального забезпечення факультету № 3 ДонДУВС, доктор юридичних наук, професор;

Короткова Ю. М. - професор кафедри соціально-гуманітарних дисциплін ДонДУВС, доктор педагогічних наук, професор;

Куракін О. М. - проректор ДонДУВС, доктор юридичних наук, доцент;

Лопатинська I. С. - доцент кафедри іноземних мов ДонДУВС, кандидат педагогічних наук, доцент;

Лоскутов Т. О. - професор кафедри організації досудового розслідування факультету № 1 КННІ ДонДУВС, доктор юридичних наук, доцент;

Мердова О. М. - завідувач кафедри адміністративно-правових дисциплін факультету № 2 ДонДУВС, кандидат юридичних наук, доцент;

Назимко Є. С. - перший проректор ДонДУВС, доктор юридичних наук, старший науковий співробітник;

Ніколенко Л. М. - завідувач кафедри господарсько-правових дисциплін та економічної безпеки факультету № 3 ДонДУВС, доктор юридичних наук, професор;

Одерій О. В. - професор кафедри кримінального процесу та криміналістики факультету № 1 ДонДУВС, доктор юридичних наук, професор;

Пайда Ю. Ю. - проректор Кам'янець-Подільського податкового інституту, доктор юридичних наук, доцент;

Пашутін В. В. - кандидат юридичних наук, доцент;

Санніков Д. В. - доцент кафедри земельного та аграрного права Національного юридичного університету ім. Ярослава Мудрого, кандидат юридичних наук, доцент;

Халимон С. І. - головний науковий співробітник науково-дослідного відділу Національної академії Державної прикордонної служби України ім. Богдана Хмельницького, доктор юридичних наук, професор.

(C Донецький державний університет внутрішніх справ, 2021 


\section{MICT}

РОЗДІЛ I

ГОСПОДАРСЬКЕ ПРАВО. ЦИВІЛЬНЕ ПРАВО. ТРУДОВЕ ПРАВО

Терехова Тамара Олексіївна

ПОНЯТТЯ ТА ОЗНАКИ КАДАСТРОВОЇ ДІЯЛЬНОСТІ. 9

\section{РОЗДІЛ ІІ \\ АДМІНІСТРАТИВНЕ ПРАВО І ПРОЦЕС. ФІНАНСОВЕ ПРАВО. ІНФОРМАЦІЙНЕ ПРАВО}

Голобутовський Роман Зіновійович ГРОМАДСЬКИЙ КОНТРОЛЬ ЗА ДІЯЛЬНІСТЮ ПУБЛІЧНИХ СЛУЖБОВЦІВ В ОРГАНАХ СУДОВОЇ ВЛАДИ

Спринцев Пилип Сергійович,

Червінчук Андрій Васильович

РЕАЛІЗАЦІЯ В УКРАЇНІ ГЛОБАЛЬНИХ ЦІЛЕЙ ДЕСЯТИЛІТТЯ ДІЙ

ІЗ ЗАБЕЗПЕЧЕННЯ БЕЗПЕКИ ДОРОЖНЬОГО РУХУ 2011-2020 РР.

Макарчук Віталій Володимирович

АДМІНІСТРАТИВНО-ПРАВОВИЙ СТАТУС ПРАВООХОРОННИХ ОРГАНІВ ЯК СУБ'ЄКТІВ ФОРМУВАННЯ ТА РЕАЛІЗАЦІЇ ДЕРЖАВНОЇ ПОЛІТИКИ У СФЕРІ НАЦІОНАЛЬНОЇ БЕЗПЕКИ І ОБОРОНИ

Цуркан Олексій Петрович

«ДОБІР» ЧИ «ВІДБІР» НА ПОСАДУ ПОЛІЦЕЙСЬКОГО:

ДО ПИТАННЯ ВИЗНАЧЕННЯ ПОНЯТЬ

Шеховцова Вікторія Володимирівна

СУЧАСНЕ БАЧЕННЯ ПРИРОДИ БЕЗПЕКИ ІНТЕЛЕКТУАЛЬНОЇ ВЛАСНОСТІ

ПІДПРИЕМСТВ УКРАЇНИ

\section{РОЗДІЛ ІІІ \\ КРИМІНАЛЬНЕ ПРАВО. КРИМІНОЛОГІЯ}

Данилевський Андрій Олександрович,

Данилевська Юлія Олександрівна

КРИМІНАЛЬНО-ПРАВОВА ОХОРОНА ЗЕМЕЛЬ, НА ЯКИХ ЗНАХОДЯТЬСЯ ОБ'ЄКТИ НЕРУХОМОЇ КУЛЬТУРНОЇ СПАДЩИНИ: АНАЛІЗ ОКРЕМИХ ЗАКОНОДАВЧИХ ІНІЦІАТИВ

Коміссаров Микола Леонідович, Коміссарова Наталя Олександрівна ТЕРМІНОЛОГІЯ КРИМІНАЛЬНОГО ПРАВА 
Назимко Сгор Сергійович,

Демчишин Дмитро Анатолійович

СОЦІАЛЬНА ОБУМОВЛЕНІСТЬ КРИМІНАЛЬНО-ПРАВОВОЇ ЗАБОРОНИ

ХУЛІГАНСЬКИХ ДІЙ

Пересада Ольга Михайлівна

ВІДМЕЖУВАННЯ УМИСНОГО ВБИВСТВА ВІД САМОГУБСТВА ТА

НЕЩАСНОГО ВИПАДКУ: ТЕОРЕТИКО-МЕТОДОЛОГІЧНІ ПІДХОДИ 88

Семенишина-Фіголь Богдана Миколаївна

ЗЕМЕЛЬНІ ВІДНОСИНИ ЯК ОБ’ЄКТ КРИМІНАЛЬНО-ПРАВОВОЇ

ОХОРОНИ В УКРАЇНІ ...... 96

Синюшко Дмитро Андрійович

ДОРЕВОЛЮЦИЙНИЙ ПЕРІОД РОЗВИТКУ ЗАКОНОДАВСТВА

3 ПРОТИДІЇ ЗЛОЧИННОСТІ У СФЕРІ ЛІСОВОГО ФОНДУ 105

Тіточка Тетяна Ігорівна

РОЛЬ НЕПОВНОЛІТНЬОЇ ЖЕРТВИ В МЕХАНІЗМІ ПЕРВЕРСИВНОЇ

КРИМІНАЛЬНО ПРОТИПРАВНОЇ ПОВЕДІНКИ

Щербіна Артем Валентинович

ГЕНЕЗА ТА ПЕРЕДУМОВИ РОЗВИТКУ АВТОМАТИЗОВАНОЇ СИСТЕМИ

ДОКУМЕНТООБГГУ СУДУ В УКРАЇНІ

\section{РОЗДІЛ IV \\ КРИМІНАЛЬНИЙ ПРОЦЕС ТА КРИМННАЛІСТИКА. ОПЕРАТИВНО-РОЗШУКОВА ДІЯЛЬНІСТЬ}

Воробей Андрій Олегович

ПРОБЛЕМНІ ПИТАННЯ ТА ПЕРСПЕКТИВИ ВДОСКОНАЛЕННЯ

СПРОЩЕНОГО ДОСУДОВОГО РОЗСЛІДУВАННЯ 132

Ковальов Костянтин Миколайович

СПЕЦІАЛЬНІ ЗНАННЯ В СУДОВІЙ ЕКСПЕРТИЗІ

ВИЗНАЧЕННЯ ДАВНОСТІ ДОКУМЕНТА .

Кубарєв Іван Володимирович,

Барган Сергій Сергійович

ТАКТИКА ДОПИТУ: ЗАКОРДОННИЙ ДОСВІД 153

Курнасва Катерина Генійовна

СЛІДЧИЙ ЕКСПЕРИМЕНТ У КРИМІНАЛЬНОМУ ПРОВАДЖЕННІ:

ІСТОРИЧНИЙ АНАЛІЗ

Савчук Марина Анатоліївна,

Шапарь Артем Олександрович

ОБГРУНТОВАНІСТЬ ПІДОЗРИ ЯК УМОВА ЗАСТОСУВАННЯ

ЗАХОДІВ ЗАБЕЗПЕЧЕННЯ КРИМІНАЛЬНОГО ПРОВАДЖЕННЯ 
Смирнов Максим Іванович

ВІДЕОКОНФЕРЕНЦІЯ ЯК ПРОЦЕСУАЛЬНА ФОРМА ВИКОРИСТАННЯ ІНФОРМАЦІЙНИХ ТЕХНОЛОГІЙ У КРИМІНАЛЬНОМУ ПРОВАДЖЕННІ УКРАЇНИ

\section{РОЗДІЛ V}

ПІДГОТОВКА ФАХІВЦІВ СИСТЕМИ ПРОФЕСІЙНОЇ ЮРИДИЧНОӤ ОСВІТИ В ЗАКЛАДАХ ВИЩОЇ ОСВІТИ ЗІ СПЕЦИФІЧНИМИ УМОВАМИ НАВЧАННЯ

Сальнікова Наталія Валеріївна

ЗАБЕЗПЕЧЕННЯ ЯКОСТІ ОСВІТИ У ВІДОМЧИХ ЗВО: СПІВПРАЦЯ 3

МІЖНАРОДНИМИ ГРОМАДСЬКИМИ ОРГАНІЗАЦІЯМИ 182

Уткіна Галина Анатоліївна,

Дацюк Тетяна Кузьмівна

ДЕЯКІ АСПЕКТИ РЕФОРМУВАННЯ ЮРИДИЧНОЇ ОСВІТИ В УКРАЇНІ 192

\section{РОЗДІЛ VI}

АКТУАЛЬНІ ПИТАННЯ ПОЛЦЕЙСЬКОЇ ДІЯЛЬНОСТІ ТА ПІДГОТОВКИ КАДРІВ ДЛЯ ПІДРОЗДІЛІВ НАЦІОНАЛЬНОЇ ПОЛЮЦЇ УКРАЇНИ

Мердова Ольга Миколаївна,

Філіпенко Анастасія Юріївна

МЕТОДИ ОЦІНЮВАННЯ ЕФЕКТИВНОСТІ ПОЛІЦЕЙСЬКОЇ ДІЯЛЬНОСТІ...... 201

ВИМОГИ ЩОДО ОФОРМЛЕННЯ ТА ПОДАННЯ СТАТЕЙ

ДО ЗБІРНИКА НАУКОВИХ ПРАЦЬ

«ПРАВОВИЙ ЧАСОПИС ДОНБАСУ»

ВІДОМОСТІ ПРО АВТОРІВ 


\title{
CONTENTS
}

\author{
SECTION I \\ COMMERCIAL LAW. CIVIL LAW. \\ LABOR LAW
}

Terekhova Tamara

THE CONCEPT AND FEATURES OF CADASTRAL ACTIVITY 9

\section{SECTION II}

ADMINISTRATIVE LAW AND PROCESS.

FINANCE LAW. INFORMATION LAW

\section{Holobutovskyi Roman}

PUBLIC CONTROL OVER THE ACTIVITIES OF PUBLIC OFFICIALS

IN THE JUDICIARY

Epryntsev Pylyp,

Chervinchuk Andriy

IMPLEMENTATION IN UKRAINE OF THE GLOBAL GOALS OF THE DECADE

OF ACTION TO ENSURE ROAD SAFETY 2011-2020

Makarchuk Vitalii

ADMINISTRATIVE AND LEGAL STATUS OF LAW ENFORCEMENT BODIES AS

SUBJECTS OF FORMATION AND IMPLEMENTATION OF STATE POLICY

IN THE FIELD OF NATIONAL SECURITY AND DEFENSE

Tsurkan Oleksiy

SELECTION FOR POLICE OFFICERS DUTY: THE QUESTION

OF THE DEFINITIONS

Shekhovtsova Victoria

THE MODERN VISION OF THE SYSTEM OF INTELLECTUAL PROPERTY RIGHTS

IN UKRAINE

\section{SECTION III \\ CRIMINAL LAW. CRIMINOLOGY}

Danylevskyi Andriy,

Danylevska Yuliya

CRIMINAL LEGAL PROTECTION OF LANDS ON WHICH THE OBJECTS

OF IMMOVABLE CULTURAL HERITAGE ARE LOCATED: ANALYSIS

OF CERTAIN LEGISLATIVE INITIATIVES

Komissarov Mykola,

Komissarova Natalia

TERMINOLOGY OF CRIMINAL LAW

Nazymko Yehor,

Demchyshyn Dmytro

SOCIAL CONDITIONALITY OF THE CRIMINAL-LEGAL PROHIBITION

OF HOOLIGAN ACTIONS 


\section{Peresada Olha}

DETERMINATION OF PREMEDITATED MURDER FROM SUICIDE AND

ACCIDENT: THEORETICAL AND METHODOLOGICAL APPROACHES.

Semenyshyna-Figol Bohdana

LAND RELATIONS AS AN OBJECT OF CRIMINAL LAW PROTECTION

IN UKRAINE

Sinyushko Dmytro

PREREVOLUTIONARY PERIOD OF DEVELOPMENT OF LEGISLATION

AGAINST CRIME IN THE FIELD OF FOREST FUND

Titochka Tetiana

THE ROLE OF A JUVENILE VICTIM IN THE MECHANISM OF PERSONAL

CRIMINAL ILLEGAL BEHAVIOR

Shcherbina Artem

GENESIS AND PREREQUISITES OF THE DEVELOPMENT OF THE

AUTOMATED COURT DOCUMENT SYSTEM IN UKRAINE

\section{SECTION IV \\ CRIMINAL PROCESS AND CRIMINALISTICS. OPERATIVE SEARCH ACTIVITY}

Vorobey Andriy

ISSUES AND PROSPECTS FOR IMPROVEMENT IN SIMPLIFYING

THE PRE-TRIAL INVESTIGATION

Kovalov Kostiantyn

SPECIAL KNOWLEDGE IN FORENSIC EXAMINATION DETERMINATION

OF THE LIMITATION PERIOD OF THE DOCUMENT

Kubariev Ivan,

Barhan Serhii

INTERROGATION TACTICS: FOREIGN EXPERIENCE. 153

\section{Kurnaieva Kateryna}

INVESTIGATIVE EXPERIMENT IN CRIMINAL PROCEEDINGS:

HISTORICAL ANALYSIS

Savchuk Maryna,

Shapar Artem

JUSTIFICATION OF SUSPICION AS A CONDITION FOR THE APPLICATION

OF CRIMINAL PROCEEDING MEASURES

Smyrnov Maksym

VIDEOCONFERENCE AS A PROCEDURAL FORM OF USING INFORMATION

TECHNOLOGIES IN CRIMINAL PROCEEDINGS OF UKRAINE 
SECTION V

TRAINING OF SPECIALISTS IN THE SYSTEM OF PROFESSIONAL LEGAL EDUCATION IN HIGHER EDUCATION INSTITUTIONS WITH SPECIFIC CONDITIONS OF EDUCATION

Salnikova Natalia

ENSURING THE QUALITY OF EDUCATION IN HIGHER EDUCATION INSTITUTIONS : THE INFLUENCE OF INTERNATIONAL

ORGANIZATIONS

Utkina Halyna,

Datsiuk Tetiana

SOME ASPECTS OF THE LEGAL EDUCATION REFORM IN UKRAINE

SECTION VI

ACTUAL ISSUES OF POLICE ACTIVITY AND TRAINING SPECIALISTS FOR UNITS OF THE NATIONAL POLICE OF UKRAINE

Merdova Olha,

Filipenko Anastasia

METHODS OF EVALUATION OF POLICY EFFICIENCY

REQUIREMENTS FOR THE REGISTRATION OF ARTICLES PUBLISHED IN THE COLLECTION OF SCIENTIFIC WORKS «LAW JOURNAL OF DONBASS» 211

INFORMATION ABOUT AUTHORS 213 


\title{
РОЗДІЛ I \\ ГОСПОДАРСЬКЕ ПРАВО. ЦИВІЛЬНЕ ПРАВО. ТРУДОВЕ ПРАВО
}

\author{
У ДК: 349.4 \\ DOI: https://doi.org/10.32366/2523-4269-2021-75-2-9-16 \\ Терехова Тамара Олексіївна, \\ аспірантка \\ (Національний юридичний університет \\ імені Ярослава Мудрого, м. Харків) \\ ORCID: https://orcid.org/0000-0001-5253-1098
}

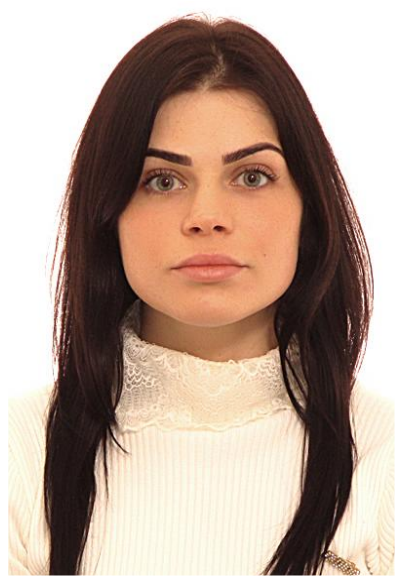

\section{ПОНЯТТЯ ТА ОЗНАКИ КАДАСТРОВОЇ ДІЯЛЬНОСТІ}

Статтю присвячено теоретичному облрунтуванню кадастрової діяльності як правової категорії, щзо надалі сприятиме поглибленому розумінню цього явища та захисту прав власників $i$ землекористувачів земельних ділянок як об'єктів такої діяльності. У статті з'ясовується, що земельно-кадастрова діяльність передбачає активні дії уповноважених органів, компетенція яких також пов'язана зі здійсненням кадастрової діяльності та забезпеченням функиій Державного земельного кадастру. Зроблено висновок, щьо земельно-кадастрову діяльність можна вважати актом прояву певних законодавчо визначених, науково обтрунтованих дій, спрямованих на забезпечення технічної, виробничої та управлінської діяльності відповідних суб'єктів, до яких належать органи державної влади ци місцевого самоврядування, наукові установи, землевпорядні організаџії тощьо, до компетенції яких входить ведення земельного кадастру, організація та виконання земельно-кадастрових робіт. На підставі аналізу законодавчих норм про кадастрову діяльність в Украӥні аргументується, що до земельно-кадастрової системи слід додатково включити інформачію про земельні ресурси, які з певних причин лишилися без власника або мають помилки в оформленні, а також земельні ділянки, що мають власника, але не використовуються чи неефективно використовуються в господарській діяльності. Це надасть змогу сформувати багаторівневу структуру ринку землі, підвищити ефективність державного управління земельними ресурсами в краӥні.

Ключові слова: кадастрова діяльність; Державний земельний кадастр; земельні ресурси; земельна ділянка; інформачія.

Постановка проблеми. У статті обгрунтовується необхідність удосконалення чинного земельного законодавства у сфері земельно-кадастрової діяльності шляхом внесення змін до Закону України «Про Державний земельний кадастр» (далі - Закон), а саме пропонується доповнити ст. 1 визначенням терміна «кадастрова діяльність» та 3'ясувати іiі роль у процесі 
обліку земель, контролю за якістю та кількістю земель, наданні інформації заінтересованим особам, організації раціонального використання та охорони земель, ефективного управління земельними ресурсами, проведення оцінки земель.

Аналіз останніх досліджень і публікацій. Зважаючи на актуальність питання визначення кадастрової діяльності, вибір теми дослідження обумовлено тим, що зазначений термін широко використовується як у спеціальній землевпорядній літературі, так й у практиці правозастосування. Проте в науці земельного права єдиного підходу до визначення цього поняття на сьогодні не існує. Окремі аспекти кадастрової діяльності були предметом вивчення таких учених, як Д. Бусуйок, Н. Грабовець, Д. Кондратенко, Т. Лісова, А. Мартин, А. Третяк, М. Шульга та інших. Їхні наукові пошуки були спрямовані лише на окремі аспекти кадастрової діяльності, однак визначення цієї категорії раніше надано не було. Ця проблематика актуалізується з огляду на те, що єдине уніфіковане тлумачення кадастрової діяльності могло б охоплювати всі її аспекти, що є надзвичайно важливим у практиці правозастосування.

Метою статті $є$ визначення юридичних ознак та формулювання категорії «кадастрова діяльність», а також з'ясування ролі такої діяльності у сфері державного управління земельними ресурсами.

Виклад основного матеріалу. У широкому розумінні поняття діяльності трактують у декількох аспектах. У психологічному аспекті діяльність визначається як специфічна форма активного ставлення людини до навколишнього середовища; процес взаємодії людини зі світом, процес активно свідомий, що веде до поставленої мети. Суть терміна «кадастрова діяльність» передбачає взаємодію відповідних державних органів і землекористувачів, що стосується вирішення питань у сфері землекористування.

У процесі дослідження взаємодії суб'єктом може бути заінтересована особа, яка звернулася до уповноваженого органу, а об'єктом - земля або земельна ділянка щодо надання інформації про неї. Згідно із Законом України «Про Державний земельний кадастр» однією із функцій, покладених на нього, є надання відповідної інформації про земельні ділянки тощо.

Визначаючи поняття кадастрової діяльності, насамперед слід скористатися літературою, у якій роз'яснюється поняття «діяльність» узагалі. Передусім варто звернути увагу на словникові джерела. Тлумачний словник так пояснює діяльність: це процес або процеси активної взаємодії суб' єкта з об' єктом, під час якого суб'єкт задовольняє будь-які свої потреби [1]. Отже, навіть на основі цього тлумачення можна в загальному вигляді виокремити певні ознаки діяльності, у тому числі й кадастрової.

Виникає запитання: що таке активні дії і як їх розуміти? Активні дії - акт вольової поведінки певного суб'єкта, спрямований на досягнення певного результату, що також можна застосувати і до визначення ознак кадастрової діяльності [1].

Діяльність як певне явище в суспільстві розглядалася протягом тривалого періоду часу вченими та філософами. Серед них І. Кант, Г. Гегель, Й.-Г. Фіхте, К. Маркс, М. Вебер та інші. Дослідники дійшли висновку, що діяльність становить четвертий елемент соціальної структури суспільства. Соціальна діяльність у всіх іiі різновидах являє собою той знаменник, до якого можна звести всю різнобічність форм громадського життя. У філософській літературі діяльність визначають як соціально-філософську категорію, що застосовується для позначення того чи іншого вияву соціальної активності, завдяки якій створюються умови громадського життя. 3 огляду на це можна стверджувати про певну суспільну корисність діяльності як суто людської форми активного ставлення до навколишнього світу. I це, у свою чергу, стосується не тільки діяльності в загальному розумінні, а й кадастрової діяльності також.

Слід звернутися до спеціальних джерел, які містять висновки фахівців у галузі землевпорядної та іншої специфічної діяльності. Як зазначає Н. Грабовець, Державний земельний кадастр - єдина система документованих відомостей про земельні ділянки. Ця думка не суперечить Закону України «Про Державний земельний кадастр», у якому також визначено, що Державний земельний кадастр $є$ геоінформаційною системою певних відомостей. Це свідчить про те, що ведення Державного земельного кадастру і все, що $з$ цим 
пов'язано, передбачає необхідність виконання таких дій, які мають юридичне значення. Тому маємо змогу узагальнити, що діяльність може бути спрямована на складання документації щодо відомостей, iї аналіз, внесення відповідної інформації про земельні ділянки до електронної системи. Тобто щоб дані потрапили до Державного земельного кадастру, їх спочатку необхідно отримати, проаналізувати, задокументувати, внести.

Закон України «Про державний земельний кадастр» указує на дії, що стосуються внесення відомостей про землі, їхнє цільове призначення, обмеження у їх використанні, даних про кількісну та якісну характеристику земель, їхню оцінку, про розподіл земель між власниками й користувачами. Проте Закон не вказує на активну участь у процесі виконання цих дій. Для створення ефективної законодавчої системи потрібна наявність конкретного визначення, у якому буде вказівка на активну діяльність органів щодо власників та користувачів з метою організації раціонального використання та охорони земель; здійснення землеустрою; проведення оцінки землі; формування та ведення містобудівного кадастру, кадастрів інших природних ресурсів; розрахунку плати за землю [2].

У загальному вигляді, грунтуючись на тому, що регламентовано в Законі й на тому, що вказує Н. Грабовець, можна стверджувати про певні напрями цієї самої кадастрової діяльності. На думку Н. Грабовець, земельно-кадастрова діяльність - це єдиний процес, у якому складові - основні види земельно-кадастрової діяльності - пов'язані між собою спільною метою забезпечити збір відомостей, необхідних для ведення Державного земельного кадастру [5].

Цю позицію можна підтримати лише частково, оскільки вона не охоплює всіх інших видів кадастрової діяльності. Для повної реалізації кадастрової діяльності необхідно забезпечувати оцінку земель, надавати повну інформацію стосовно якості та кількості земель. Учинення діяльності в межах певних активних дій щодо окремих видів процедур і процесів, які виконує та регулює Державний земельний кадастр, у результаті матиме негативні наслідки.

На думку М. Володіна, кадастрова діяльність здійснюється у дві черги. I первинними заходами є визначення розташування, розмірів, площі, конфігурації, показників природних і набутих властивостей земельної ділянки [6]. На цій підставі можна зробити висновок, що поняття кадастрової діяльності поділяється не лише на певні дії органів, а й на землекористування в цілому, що дає можливість розглядати зазначене поняття ширше. 3 цим важко погодитися, оскільки землекористування передбачає самостійний процес втілення суб'єктивних прав суб'єкта на земельну ділянку.

Землекористування можна розглядати в аспекті реалізації права власності, коли йдеться про одну з правомочностей власника, яку встановлено Земельним кодексом України щодо користування земельною ділянкою. Більш загально можна трактувати землекористування як землевикористання, у такому разі це вже буде вважатися самостійною категорією земельного права, яка стосується кадастрової діяльності дуже опосередковано, тому що землекористування і використання земель знаходить своє відображення лише у відповідному розділі Державного земельного кадастру. Але ототожнювати процес землекористування із кадастровою діяльністю не можна. Визначення М. Володіна дає змогу стверджувати, що існують заходи, серед яких і $є$ певна активна, вольова поведінка спеціально уповноваженого суб'єкта, який має повноваження розраховувати розмір площі, конфігурацію, показники. Така поведінка суб’єктів також і є ознакою кадастрової діяльності. Якщо проаналізувати Закон України «Про Державний земельний кадастр», то з'ясуємо, що зазначена діяльність зобов'язує вчиняти певні дії, які визначені законодавством і які мають специфічний суб'єктний склад.

Результатом кадастрового процесу $є$ інтегровані просторово-якісні характеристики, представлені в документах правового статусу об'єктів, реєстрах нерухомості, базах даних, тематичних земельно-інформаційних комплексах і т. п. [4]. Характеристика ознак кадастрової діяльності свідчить про те, що вони не суперечать законодавству, це ж саме стосується $\mathrm{i}$ землеустрою, який передбачає вольову законну поведінку.

Аналізуючи кадастровий процес, М. Володін робить певні висновки, пов'язані 3 кадастровою діяльністю [6]. Зокрема, кадастровий процес, як і кадастрова діяльність, має певний напрям руху. Він передбачає пізнання навколишнього середовища, тобто ознакою 
кадастрової діяльності $є$ певна мета, яка полягає у формуванні Державного земельного кадастру, наповненні бази даних, аналізі інформації тощо. Наведене $\epsilon$ ключовими особливостями кадастрового процесу як засобу цілеспрямованого пізнання навколишнього середовища. У цьому його найхарактерніша властивість, яка в поєднанні з іншими ознаками $\epsilon$ підгрунтям для відображення єдиної функціональної сутності кадастру через відповідно розроблене формулювання: кадастр - це система пізнання і документування середовища існування людини, побудована на основі вивчення атрибутів земельної ділянки 3 метою регулювання (створення) землекористування.

На думку Д. Бусуйок, вимоги щодо повноти інформації про об'єкти кадастрів, достовірності такої інформації доцільно поширити на діяльність із ведення усіх кадастрів [10]. Таким чином, кадастрова діяльність може розповсюджуватися не лише на земельний кадастр.

У своїй монографії Д. Бусуйок зазначає, що для більш ефективної та оперативної роботи кадастрів необхідно прийняти Закон України «Про кадастри» [10], у якому також можна буде зафіксувати діяльність органів, що буде розповсюджуватися не лише на земельний кадастр, а й на діяльність інших кадастрів - водного, лісового та ін. Необхідність ведення системи кадастрів пов'язана не з одним органом, а із спеціальними органами, компетенція яких стосується регулювання діяльності у відповідній сфері з використанням природних ресурсів, природних об'єктів тощо. Ці органи мають взаємодіяти, узгоджувати та координувати свою діяльність щодо ведення єдиної системи кадастрів.

Повноцінне дослідження довкілля стає головною умовою створення сучасного землекористування. Саме воно перешкоджає конфлікту навколишнього середовища iз способами його використання, дозволяючи обгрунтувати характер виробничих процесів найбільш прийнятними методами. Убачається, що формування такого знання можливе лише завдяки врахуванню повної сукупності властивостей середовища, яке утворюється через взаємодію всіх його компонентів, тобто на основі функціональності середовища. Цей термін $\epsilon$ зручним повномасштабним відображенням реального об'єкта кадастрової діяльності [6].

Для забезпечення законодавчих стандартів просторової ідентифікації кадастрової діяльності розроблено принципові засади формування дефініції центрального об'єкта зазначеної діяльності - земельної ділянки, яка створюється в результаті визначення основних рівнів організації об'єкта та відповідних груп суттєвих ознак, сприяючи однозначному тлумаченню цієї категорії.

Аналізуючи такий підхід, можна зробити висновок, що поняття кадастрової діяльності поділяється не лише на певні дії органів, а й на землекористування в цілому, що дає змогу розглядати його більш узагальнено.

Як зазначає Л. Перович, поняття кадастрів в Україні слід ідентифікувати як систему реєстрації земельних ділянок з усіма притаманними ім характеристиками, необхідними для соціально-економічного розвитку територій [7]. Проте для забезпечення більш ефективної роботи кадастру цього визначення буде недостатньо. Згідно із Законом України «Про Державний земельний кадастр» до його функцій також належить державний контроль за використанням земель, цільове призначення, управління земельними ресурсами. Уповноважені органи виконують й інші завдання, до того ж їх значно більше, ніж визначено Л. Перовичем, що й передбачено відповідними нормами Закону.

Ведення земельного кадастру, який варто розглядати як повну інформаційну базу, у котрій містяться відомості про цільове призначення і використання, кількісну та якісну характеристики земель, зумовлене об'єктивними потребами суспільства в оперативному отриманні точної і достовірної інформації про землю як джерело матеріальних благ та об'єкт права власності й оподаткування. Словосполучення «ведення земельного кадастру» вказує на вчинення певних дій спеціальними суб'єктами. Однак веденню передує така діяльність, як створення цього кадастру і його наповнення. Таким чином, передусім варто з'ясувати, що являє собою земельний кадастр. Згідно зі ст. 195 Земельного кодексу України основним завданням ведення Державного земельного кадастру є, серед іншого, забезпечення повноти відомостей про всі земельні ділянки. Повнота відомостей Державного земельного кадастру на 
сьогодні має опосередковуватися застосуванням новітніх інформаційних технологій обліку документів та відомостей, що в них вміщені. Це потребує внесення змін до Закону, щоб більш детально розглядати процеси діяльності. Необхідно запровадити нові конкретні терміни, які регулюватимуть дії щодо ведення Державного земельного кадастру.

Відповідно до Закону завданнями Державного земельного кадастру також є: регулювання земельних відносин; управління земельними ресурсами; організація раціонального використання та охорони земель; здійснення землеустрою; проведення оцінки землі; формування та ведення містобудівного кадастру, кадастрів інших природних ресурсів; розрахунок плати за землю.

Щодо повноти відомостей про земельні ділянки варто зауважити, що відомості Державного земельного кадастру на сьогодні мають опосередковане застосування. Закон України «Про Державний земельний кадастр» указує на конкретні дії, що вчиняє орган, проте не дає визначеної характеристики такої діяльності. Законом передбачена дія або бездіяльність уповноважених осіб, регулювання конкретної їхньої діяльності. Процес здійснення процедур $\epsilon$ активними діями, але потрібно регламентувати, що саме $\epsilon$ діяльністю у сфері регулювання земельних відносин.

Ідентифікація земельних ділянок, що забезпечувала б максимальну інформативність та відсутність помилок, дублювань, побудована на основі використання так званого кадастрового номера земельної ділянки відповідно до вказівки Державного комітету України по земельних ресурсах від 16.02.1998 р. № 9 «Про створення єдиної системи нумерації земельних ділянок для ведення державного земельного кадастру». Згаданий документ визначає, що кадастровий номер земельної ділянки - «унікальний (що не повторюється на всій території України) номер, який присвоюється під час формування земельної ділянки і зберігається за нею на весь час їі існування» [2].

Одним із головних недоліків наявного земельного кадастрового обліку слід уважати його статистичний характер. Починаючи з радянських часів, актуалізація кадастрових даних замінювалася веденням статистичної звітності з кількісного обліку земель (за формами № 6зем, № 6а-зем, № 2-зем, які сьогодні вже не діють), просторові характеристики обліковувалися 3 недостатньою точністю та ретельністю [8]. Варто звернути увагу на визначення у відомостях і документах даних, які характеризують кожну земельну ділянку, землі за площею і складом земельних угідь, а також розподіл їх за власниками й землекористувачами; про якісні параметри земель, які характеризують земельні угіддя за природними й набутими властивостями, що впливають на їхню продуктивність та економічну цінність, а також за ступенем техногенного забруднення грунтів. Облік земель як окремий напрям діяльності уповноважених органів щодо забезпечення раціонального й ефективного використання, охорони й відновлення земель традиційно визнавався самостійною функцією публічного управління в галузі земельних відносин [9].

3 огляду на визначення, яке надає Д. Кондратенко, можна стверджувати, що облік земель передбачає активні дії уповноважених органів, які також відносяться до здійснення кадастрової діяльності та виконання функцій Державного земельного кадастру. Отже, метою Державного земельного кадастру є забезпечення органів державної влади й місцевого самоврядування, фізичних і юридичних осіб інформацією про статус тієї чи іншої земельної ділянки, її якісні й кількісні характеристики, цільове призначення. Такі відомості їм необхідні для: регулювання земельних відносин; ефективного управління земельними ресурсами; раціонального використання та охорони земель; здійснення землеустрою; проведення оцінки землі; ведення містобудівного кадастру, кадастрів інших природних ресурсів; справляння плати за землю [9]. Кадастрова діяльність здійснюється для того, щоб фахівці в тій чи іншій сфері виконували певні завдання, забезпечуючи при цьому безперервність роботи інших спеціалістів. Вони працюють заради досягнення головної цілі - постійного оновлення Державного земельного кадастру, дотримання оперативності, вичерпності, правдивості відомостей, включених до нього, їх доступності. 
Висновки. Підсумовуючи, вбачаємо можливим визначити поняття «земельнокадастрова діяльність» як акт прояву певних законодавчо визначених, науково обгрунтованих дій, спрямованих на забезпечення технічної, виробничої та управлінської діяльності відповідних суб'єктів, до яких належать органи державної влади й місцевого самоврядування, наукові установи, землевпорядні організації та інші, компетенцією яких є ведення земельного кадастру, організація та виконання земельно-кадастрових робіт. На підставі викладеного можна зробити висновок про ознаки кадастрової діяльності, які притаманні саме їй.

По-перше, зазначена діяльність нормативно врегульована й законодавчо закріплена Законом України «Про Державний земельний кадастр», здійснення кадастрової діяльності відбувається відповідно до законодавчих норм, що забезпечують дотримання певних вимог та запобігають порушенню земельних прав як з боку землекористувачів і землевласників, так і 3 боку державних органів. По-друге, діяльність - сукупність дій, що забезпечує громадянам безперешкодний доступ до інформації, значно спрощує процедуру надання відомостей щодо земельних ділянок, регулюється законами України «Про Державний земельний кадастр» $\mathrm{i}$ «Про доступ до публічної інформації». По-третє, така діяльність передбачає виконання активних, визначених законодавством дій, що вчиняються суб'єктами, перелік яких також затверджено Законом.

Щоб наблизити вітчизняну кадастрову систему до європейської, досягти іiі відповідності світовим стандартам, необхідно домогтися повної реєстрації інформації про земельні ресурси з усіма притаманними їм характеристиками. Важливо при цьому пам'ятати, що збір даних, узагальнення інформації про стан, кількісні та якісні показники земельних ресурсів - це не кінцева мета створення кадастрових систем, головне - їхня зручність, затребуваність такої інформації і доцільність використання. Таким чином, для підвищення ефективності функціонування земельно-кадастрової системи в Україні до останньої слід включити інформацію про земельні ресурси, які з певних причин лишилися без власника або мають помилки в оформленні; ділянки, що мають власника, але не використовуються (або неефективно використовуються) в господарській діяльності. Це дасть змогу сформувати багаторівневу структуру ринку землі, вдосконалити державне регулювання.

Крім того, доцільно у структурі земельно-кадастрової системи об'єднати інформацію різних напрямів, що зробить ії комплексною, а також відповідатиме сучасним екологічним, економічним та юридичним вимогам. Забезпечення надання статистичної інформації в режимі реального часу дасть змогу вітчизняним органам державної влади приймати раціональні й оперативні рішення щодо управління земельними ресурсами, враховуючи актуальні й достовірні статистичні дані.

\section{Список використаних джерел}

1. Академічний тлумачний словник української мови (1970-1980). Том 2. 1971. $550 \mathrm{c}$.

2. Вказівка Державного комітету України по земельних ресурсах від 16.02.1998 p. № 9 «Про створення єдиної системи нумерації земельних ділянок для ведення державного земельного кадастру».

3. Данильян О. Г., Дзьобань О. П. Філософія : підручник. Харків : Право, 2018. $345 \mathrm{c}$.

4. Про Державний земельний кадастр : Закон України від 07.07.2011 р. № 3613-VI. Відомості ВерховноїРади України. 2012. № 8. Ст. 61.

5. Грабовець Н. О. Правове забезпечення основних видів земельно-кадастрової діяльності в Україні : автореф. дис. ... канд. юрид. наук : 12.00.06 / Нац. ун-т біоресурсів і природокористування України. Київ, 2011. 18 с.

6. Володін М. О. Теоретичні основи формування кадастрового забезпечення базових процесів використання земельних ресурсів : автореф. дис. ... д-ра техн. наук : 05.24.04. Київ, 2004. 36 с. 
7. Перович Л., Лудчак О. Кадастрова система України в контексті світового розвитку. Сучасні досягнення геодезичної науки та виробництва. 2015. Вип. 1. С. 15-19.

8. Мірошниченко А. М., Марусенко Р. I. Науково-практичний коментар до Земельного кодексу України. Київ : Правова єдність, 2009. 496 с.

9. Кондратенко Д. Ю. Окремі питання обліку земель як правової категорії. Підприємництво, господарство і право. 2020. № 3. С. 109-114.

10. Бусуйок Д. В. Управлінські та сервісні правовідносини в земельному праві України : монографія. Київ : Ніка-Центр, 2017. 352 с.

\section{References}

1. Akademichnyi tlumachnyi slovnyk ukrainskoi movy (1970-1980). Tom 2. 1971. $550 \mathrm{~s}$.

2. Vkazivka Derzhavnoho komitetu Ukrainy po zemelnykh resursakh vid 16.02.1998 r. № 9 «Pro stvorennia yedynoi systemy numeratsii zemelnykh dilianok dlia vedennia derzhavnoho zemelnoho kadastru».

3. Danylian, O. G., Dzoban, O. P. (2018). Filosofiia [Philosophy] : pidruchnyk. Kharkiv. 345 s. [in Ukrainian].

4. Pro Derzhavnyi zemelnyi kadastr : ZakonUkrainy vid 07.07.2011 r. № 3613-6 [About State Land Cadastra : Law of Ukraine dated 07.07.2011 № 3613-VI]. Vidomosti Verkhovnoi Rady Ukrainy. 2012. № 8. St. 61 [in Ukrainian].

5. Hrabovets, N. O. (2011). Pravove zabezpechennia osnovnykh vydiv zemelnokadastrovoi diialnosti v Ukraini [Legal support of the main types of land and cadastral activity in Ukraine] : avtoref. dys. ... kand. yuryd. nauk : 12.00.06 / Nats. un-t bioresursiv i pryrodokorystuvannia Ukrainy. Kyiv. 18 s. [in Ukrainian].

6. Volodin, M. O. (2004). Teoretychni osnovy formuvannia kadastrovoho zabezpechennia bazovykh protsesiv vykorystannia zemelnykh resursiv [Theoretical bases of the formation of cadastral provision of basic processes of use of land resources] : avtoref. dys. ... d-ra tekhn. nauk : 05.24.04. Kyiv. 36 s. [in Ukrainian].

7. Perovych, L., Ludchak, O. (2015). Kadastrova systema Ukrainy v konteksti svitovoho rozvytku [Cadastral system of Ukraine in the context of world development]. Suchasni dosiahnennia heodezychnoi nauky ta vyrobnytstva. Vyp. 1. S. 15-19 [in Ukrainian].

8. Miroshnychenko, A. M., Marusenko, R. I. (2009). Naukovo-praktychnyi komentar do Zemelnoho kodeksu Ukrainy [Scientific and practical commentary to the Land Code of Ukraine]. Kyiv : Pravova yednist. 496 s. [in Ukrainian].

9. Kondratenko, D. Yu. (2020). Okremi pytannia obliku zemel yak pravovoi katehorii [Separate land accounting questions as a legal category]. Pidpryiemnytstvo, hospodarstvo i pravo. № 3. S. 109-114 [in Ukrainian].

10. Busuiok, D. V. (2017). Upravlinski ta servisni pravovidnosyny v zemelnomu pravi Ukrainy [Management and service relations in land law of Ukraine] : monohrafiia. Kyiv : NikaTsentr. 352 s. [in Ukrainian].

Terekhova Tamara,

Postgraduate Student

(Yaroslav Mudryi National Law University, Kharkiv)

ORCID: https://orcid.org/0000-0001-5253-1098 


\section{THE CONCEPT AND FEATURES OF CADASTRAL ACTIVITY}

The article is devoted to the theoretical substantiation of cadastral activity as a legal category, which will further contribute to an in-depth understanding of this phenomenon and protection of the rights of owners and land users of land plots as objects of such activity. The article argues that the implementation of land cadastral activities involves active actions of authorized bodies, whose competence is also related to the implementation of cadastral activities and ensuring the functions of the State Land Cadastre. It is concluded that land cadastral activity can be considered an act of manifestation of legally defined, scientifically justified actions aimed at ensuring the technical, production and management activities of the relevant entities, which include public authorities and local governments, research institutions, land management organizations, etc., aimed at maintaining the land cadastre, organization and implementation of land cadastral works. It is substantiated that the maintenance of land cadastre, which should be considered as a complete information base, which contains information on the purpose and use, quantitative and qualitative characteristics of land, due to the objective needs of society in obtaining accurate and reliable information about land as a source of material goods and object property rights and taxation. Based on the analysis of legislative norms on cadastral activity in Ukraine, it is argued that the land cadastral system should additionally include information on resources that for some reason were left without an owner, or have errors in design; plots that have an owner, but are not used or inefficiently used in economic activities. This will allow to form a multilevel structure of the land market, increase the efficiency of state management of land resources in the country. The methodology of research of essence and signs of land cadastral activity is based on provisions of the general scientific dialectical method of scientific knowledge. In addition, formal-legal and formal-logical methods were used for full and comprehensive disclosure of the research topic.

Key words: cadastral activity; State land cadastre; land resources; land; information.

Надіслано до редколегії 05.04.2021

Рекомендовано до публікації 12.04.2021 


\title{
РОЗДІЛ ІІ \\ АДМІНІСТРАТИВНЕ ПРАВО І ПРОЦЕС. ФІНАНСОВЕ ПРАВО. ІНФОРМАЦІЙНЕ ПРАВО
}

УДК: 342.9

DOI: https://doi.org/10.32366/2523-4269-2021-75-2-17-24

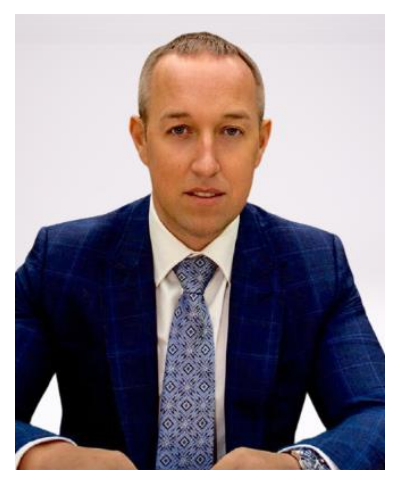

\author{
Голобутовський Роман Зіновійович, \\ доктор юридичних наук \\ (Дніпропетровський державний університет \\ внутрішніх справ, м. Дніпро) \\ ORCID: https://orcid.org/0000-0003-4720-9189
}

\section{ГРОМАДСЬКИЙ КОНТРОЛЬ ЗА ДІЯЛЬНІСТЮ ПУБЛІЧНИХ СЛУЖБОВЦІВ В ОРГАНАХ СУДОВОЇ ВЛАДИ}

У статті проаналізовано систему громадського контролю за діяльністю публічних службовців в органах судової влади. Досліджено поняття «громадський контроль» та «публічна служба в органах судової влади». На основі вказаних підходів запропоновано власне науково обтрунтоване визначення. 3'ясовано нормативно-правову основу здійснення громадського контролю за органами судової влади в Україні та особливості такої діяльності. Досліджено наукові положення щодо форм громадського контролю за публічними службовиями в органах судової влади, серед яких виділено соиіологічні та статистичні дослідження, громадські слухання, громадську експертизу актів органів публічної влади, перевірку діяльності будь-якої організачії або відповідальної особи, аналіз звернень громадян тощяо.

Ключові слова: громадськість; громадський контроль; суд; публічна служба; публічна служба в органах судової влади; форми контролю.

Постановка проблеми. Розвиток демократичної, правової та соціальної держави полягає в ефективній взаємодії всіх ii інститутів, а також активній участі громадянського суспільства в механізмі контролю і нагляду за діяльністю органів публічної влади. Одним 3 найважливіших аспектів побудови високорозвиненої держави $\epsilon$ функціонування незалежної та високоавторитетної судової влади, яка має фундаментальне значення в механізмі захисту прав і свобод людини та громадянина. Однак досягнення зазначеної мети неможливе без участі громадськості, яка є гарантом прозорості, об'єктивності та відкритості судів в Україні.

Сьогодні в нашій державі триває реформа розвитку органів правосуддя, що обумовлює необхідність у комплексному теоретико-правовому аналізі якості залучення громадян до роботи органів судової влади. Особливого значення набуває проблема законодавчої невизначеності форм громадського контролю за діяльністю публічних службовців в органах судової влади, оскільки нормативна невизначеність зумовлює неоднакове тлумачення меж такого контролю, а також можливість зловживання 3 боку інститутів громадянського суспільства та органів публічної влади. 
Аналіз останніх досліджень і публікацій. Значення контролю як соціального явища обгрунтовано в дослідженнях таких учених, як В. Авер'янов, І. Голосніченко, В. Горшеньов, О. Данільян, А. Карась, М. Кельман, В. Таран та ін. Державний контроль вивчали: С. Авакьян, Д. Бахрах, Ю. Битяк, В. Гаращук, Є. Додін, Р. Калюжний, С. Ківалов, В. Колпаков, А. Малишев, Н. Нижник, А. Селіванов, В. Семчик, В. Сіренко, В. Цвєтков, Ю. Шемшученко та ін. Проблему громадського контролю за діяльністю владних інституцій як невід'ємну складову гармонійного розвитку суспільства і держави розглянуто в контексті суб'єктного та об'єктного складу в роботах таких науковців: О. Бондарчук, А. Буханевич, Л. Гапоненко, В. Гаращук, А. Денисенко, С. Денисюк, М. Іжа, П. Каблак, Ю. Ковбасюк, С. Косінов, В. Кравчук, А. Крупник, С. Кушнір, О. Музичук, Л. Наливайко, Т. Наливайко, С. Прилуцький, Г. Пришляк, Л. Рогатіна, О. Савченко, В. Синчук, О. Сушинський, О. Хотинська-Нор та ін. Але більшість наукових розробок мають на меті дослідження взаємодії органів судової влади та інститутів громадянського суспільства, тоді як контрольна функція громадськості залишається недостатньо дослідженою.

Формування цілей статті (постановка завдання). Метою статті $є$ визначення поняття громадського контролю за діяльністю публічних службовців в органах судової влади, правовий аналіз його нормативного забезпечення, а також дослідження найбільш ефективних моделей такої взаємодії, адже принцип незалежності судової гілки влади зумовлює складність щодо розмежування легального контролю та незаконним втручанням у діяльність суду.

Виклад основного матеріалу. Характеристика громадського контролю за діяльністю публічних службовців в органах судової влади $\epsilon$ неможливою без визначення поняття «громадський контроль», який є одним з найбільш ефективних механізмів взаємодії інститутів громадянського суспільства та органів публічної влади, а також $\epsilon$ індикатором демократичності будь-якої соціально-орієнтованої держави.

Т. Наливайко пропонує досліджувати громадський контроль як один із видів соціального контролю, що здійснюється громадськими об'єднаннями та безпосередньо самими громадянами, $\epsilon$ важливим засобом реалізації народовладдя та дієвим способом залучення населення до управлінської діяльності. Функціонування громадського контролю в демократичному суспільстві розглядається як цілеспрямований та дієвий вплив соціальних суб' єктів на поведінку агентів соціальної взаємодії [9, с. 9]. О. Савченко трактує громадський контроль як активне спостереження представників громадськості (громадян та їх об'єднань) 3 використанням системи правових, організаційних, інформаційних та інших засобів (перевірки, порівняння, оцінювання) з метою забезпечення неухильного дотримання законності, реалізації прав і свобод населення [18, с. 46]. А. Крупник наголосив на характерних відмінностях громадського контролю від будь-якого іншого виду контролю і визначив громадський контроль як інструмент громадської оцінки ступеня виконання органами влади та іншими підконтрольними об’єктами їхніх соціальних завдань [8]. На думку О. Хотинської-Нор, такий контроль $є$ зовнішнім регулятором процесів розвитку судової системи, скеровуючи їх у русло відповідних суспільних очікувань, узгоджуючи їх 3 інтересами соціуму на кожному історичному етапі його розвитку і забезпечуючи в такий спосіб еволюцію судової системи та iii взаємозв'язок із суспільством [19, с. 110]. В. Кравчук переконаний, що громадський контроль за судовою владою може дати поштовх до створення ефективної та справедливої судової системи, забезпечити відкритість і прозорість функціонування судової влади, а це, у свою чергу, сприятиме збільшенню рівня довіри громадськості до судів [7, с. 12]. Попри деякі розбіжності лексичного значення поняття, у цілому автори займають єдину позицію щодо трактування громадського контролю як права та законної можливості суб'єктів здійснювати контрольні повноваження щодо державних органів i посадовців 3 метою розвитку громадянської активності та забезпечення дотримання принципів верховенства права, публічності й ефективності в роботі цих осіб.

Для розуміння сутності такої діяльності варто з'ясувати зміст поняття «публічна служба в органах судової влади». На законодавчому рівні визначення терміна «публічна служба» закріплено в п. 17 ст. 4. Кодексу адміністративного судочинства України, згідно 3 
яким публічна служба - діяльність на державних політичних посадах, у державних колегіальних органах, професійна діяльність суддів, прокурорів, військова служба, альтернативна (невійськова) служба, інша державна служба, патронатна служба в державних органах, служба в органах влади Автономної Республіки Крим, органах місцевого самоврядування [4]. Доцільно зауважити, що законодавче формулювання поняття не розкриває його сутності, а тільки перелічує види публічної діяльності. У зв'язку з цим слід дослідити доктринальні визначення.

Так, О. Попова тлумачить публічну службу як реалізацію народом влади через виконання завдань і функцій держави, спрямованих на забезпечення публічних інтересів особами на постійній професійній відплатній основі за рахунок бюджетних коштів в органах виконавчої влади, апаратах усіх гілок органів влади, органах місцевого самоврядування на підставі адміністративно-правового акта про призначення на посаду [12, с. 586]. Н. Рунова пропонує розглядати публічну службу як здійснення влади суспільством (народом) через професійну діяльність публічних службовців [17, с. 272]. Публічну службу в органах судової влади слід розуміти як політично-нейтральну професійну службу на посаді судді в судах, в інших органах суддівського врядування, державних органах та установах системи правосуддя задля організації та забезпечення діяльності судів та суддів.

Узагальнюючи зазначені підходи щодо визначення поняття, пропонуємо розглядати громадський контроль за діяльністю публічних службовців в органах судової влади як вид соціального контролю, що полягає у публічній перевірці результатів діяльності публічних службовців в органах судової влади з використанням відповідно до законодавства України комплексу правових та організаційних заходів 3 боку громадян та їх об'єднань для забезпечення ефективності, прозорості та об'єктивності їхньої роботи.

Інституційною складовою громадського контролю за діяльністю органів судової влади, від якого значною мірою залежить його ефективність, а також важливим елементом комунікації між судовою владою і громадськістю є засоби масової інформації, зокрема засоби електронної комунікації. Вони забезпечують інформування громадян про роботу судів та стан законності й правопорядку в державі, а суддів - про громадську думку з цих питань [6, с. 97]. Саме тому необхідною умовою діяльності засобів масової інформації є їхня свобода, політична незаангажованість, незалежність від монопольного впливу держави, політичних партій, фінансово-політичних груп тощо, а також транспарентність судової влади.

Громадський контроль забезпечує приватним особам можливість брати участь у реформуванні судової системи взагалі та судів зокрема шляхом виявлення нормативних, організаційних, технічних та інших недоліків у діяльності останніх [11, с. 122]. Важливо зауважити, що він повинен здійснюватися насамперед 3 метою захисту прав людини. Особистість, іï всебічний розвиток, добробут, права та свободи $\epsilon$ найвищою цінністю сучасного суспільного прогресу і будь-якої контрольної діяльності. На цій підставі цілком справедливо сучасними векторами функціонування інституту громадського контролю називають такі ціннісні орієнтири: екзістенціально значущий порядок у суспільстві, зростання масштабу свободи соціальних суб' єктів, формування соціально-конструктивних світоглядних орієнтацій особистості для розвитку ії ініціатив і реалізації творчих потенціалів [2, с. 30].

Ефективність контролю за діяльністю публічних службовців в органах судової влади забезпечується за умови неухильного додержання таких принципових вимог: контроль повинен бути об'єктивним та безстороннім; контроль передбачає відкритість та прозорість, адже це основні вимоги до ефективності державної влади, сформованої демократичним шляхом; контроль має бути публічним та гласним, що передбачає доведення отриманої підсумкової інформації, результатів контролю до громадськості та зацікавлених осіб; контроль повинен бути обгрунтованим i цілеспрямованим, що забезпечить його результативність та ефективність; науковість і професіоналізм як принципи громадського контролю, які передбачають залучення до здійснення контролю фахівців (правників, колишніх почесних суддів, науковців), що дозволить уникнути можливих зловживань, поверхового підходу до контролю, забезпечить детальну та професійну оцінку роботи судді та прийнятих 
ним правозастосовних актів [5, с. 60-61]. Крім зазначених основних засад громадського контролю, важливе значення під час його здійснення має громадянська активність та незалежність суб'єктів контролю, відповідність їхніх дій чинному законодавству, справедливість і обгрунтованість їхніх висновків, готовність до відповідальності за свої дії та рішення.

Нормативно-правову основу громадського контролю за публічними службовцями в органах судової влади становлять Конституція України, міжнародні договори, закони України та інші нормативно-правові акти. Зокрема, Закон України «Про судоустрій і статус суддів» (далі - Закон) упорядкував і вдосконалив можливості громадського контролю суддів та судової влади. Так, відповідно до п. 3 ч. 7 ст. 56 Закону кожен суддя зобов'язаний, окрім декларування свого майнового стану, подавати декларації про свою доброчесність та родинні зав'язки, які стають доступними для загалу через оприлюднення на офіційному вебсайті Вищої кваліфікаційної комісії суддів України. У декларації родинних зав'язків судді подаватимуть відомості про близьких осіб та родичів, які займають відповідальні державні посади. Ця інформація допомагає виявити конфлікт інтересів та попередити інші чинники можливої упередженості суддів під час виконання ними своїх повноважень. Відомості, що подані в декларації, після іiі опублікування стають предметом громадського контролю і за відсутності доказів іншого твердження судді вважаються достовірними, що засвідчує доброчесність судді та забезпечує йому громадську довіру [15]. Також Законом передбачено створення Громадської ради доброчесності з метою сприяння Вищій кваліфікаційній комісії суддів України у встановленні відповідності судді критеріям професійної етики та доброчесності для кваліфікаційного оцінювання, а також кандидатів на посаду судді. Поведінка судді стає предметом громадського контролю не лише під час виконання ним своїх функцій, а й в особистому житті. Це справедливо і не може розглядатися як порушення особистого простору судді, оскільки судді наділені широкими повноваженнями [15]. Також розроблено і прийнято за основу проєкт Закону України «Про інформаційну відкритість органів державної влади та вищих посадових осіб України» [14], який визначає умови та порядок забезпечення інформаційної відкритості в діяльності органів державної влади та вищих посадових осіб України.

Доброчесність та етична поведінка публічних службовців в органах публічної влади відповідає п. 20 Рекомендації CM/Rec (2010) 12, відповідно до якої судді не можуть ефективно здійснювати правосуддя без довіри громадськості, адже вони є частиною суспільства, якому служать [16]. Це гарантує первинну легітимність судді та в подальшому - функціональну. Формування громадської думки щодо переконання у правоті, незалежності та об'єктивності судової влади є запорукою стабільності в суспільстві та державі.

Формами здійснення громадського контролю вчені вважають соціологічні та статистичні дослідження, громадські слухання, громадську експертизу актів органів публічної влади та їхніх проєктів, публікації у пресі, випуски на радіо, телебаченні, оприлюднення інформації в інтернет-мережі; громадську експертизу, участь громадськості в роботі колегіальних органів влади, перевірку діяльності будь-якої організації або відповідальної особи, аналіз звернень громадян, результатів діяльності тощо [1, с. 114]. Громадський контроль судової влади, як зазначає П. Каблак, може здійснюватися методами спостереження, опитування, аналізу, прогнозування тощо, водночас дослідник звертає увагу на особливу результативність використання методу опитування за допомогою карток громадянського звітування [3, с. 99; 132]. Формами здійснення громадського контролю судової влади можуть бути: соціологічні та статистичні дослідження, діяльність громадських рад, рідко - оцінка винесених суддею рішень, їхньої відповідності принципам і нормам права, моральним засадам суспільства. До того ж громадський контроль за публічними службовцями в органах судової влади можна класифікувати за двома основними напрямами: за видом суду та за формою контролю.

Важливо зауважити, що громадський контроль жодним чином не є знаряддям примусу, 3 його допомогою неможливо керувати, наказувати судовій владі здійснювати певні дії. 
Разом із тим слід зазначити про відсутність чіткої процедурної регламентації механізмів контролю, що негативно позначається на поширенні закономірної тенденції, згідно 3 якою у процесі становлення і розвитку громадянського суспільства мала б зростати роль самоорганізації та організації як важливих процесів структуризації суспільних відносин [10, c. 45]. Для подолання вказаних недоліків у законодавстві народними депутатами було подано до Верховної Ради України законопроєкт № 9013 від 07.08.2018 року «Про громадський контроль», у якому було запропоновано такі форми контролю: поточний; перевірка за зверненнями громадян; громадська експертиза; громадські слухання [13].

Висновки. Отже, забезпечення ефективної та прозорої діяльності органів судової влади $\epsilon$ запорукою розвитку демократичного, правового й соціального суспільства та держави. Громадський контроль за діяльністю публічних службовців в органах судової влади може бути визначено як вид соціального контролю, що полягає в публічній перевірці результатів діяльності публічних службовців в органах судової влади 3 використанням відповідно до законодавства України комплексу правових та організаційних заходів з боку громадян та їх об'єднань для забезпечення ефективності, прозорості та об'єктивності їхньої роботи. Основними формами вказаної діяльності $є$ такі: соціологічні та статистичні дослідження, діяльність громадських рад, рідко - оцінка винесених суддею рішень, їхньої відповідності принципам і нормам права, моральним засадам суспільства.

Особливого значення в зазначеній сфері набуває питання закріплення організаційних форм такого контролю, однак сьогодні воно є законодавчо неврегульованим, що обумовлює необхідність розробки та прийняття спеціального законодавчого акта про діяльність уповноважених на здійснення громадського контролю суб’єктів і форм такої діяльності.

\section{Список використаних джерел}

1. Енциклопедія державного управління : у 8 т. / наук.-ред. колегія: Ю. В. Ковбасюк (голова), В. М. Князєв (співголова), І. В. Розпутенко (співголова) та ін.; Нац. акад. держ. упр. при Президентові України. К. : НАДУ, 2011. Т. 1: Теорія державного управління. 748 с.

2. Жуков С. В. Елементний склад адміністративно-правового забезпечення доброчесності суддів. Свропейські перспективи. 2019. № 1. С. 29-33.

3. Каблак П. І. Взаємовідносини судової влади та громадськості (правові і організаційні аспекти) : дис. ... канд. юрид. наук. Львів, 2015. 211 с.

4. Кодекс адміністративного судочинства : Закон України від 06.07.2005 року № 2747-IV (зі змінами і допов.). Відомості Верховної Ради України. 2005. № 35-36. № 37. Ст. 446.

5. Копетюк М. І. Адміністративний суд як суб’єкт адміністративного судочинства. Історико-правовий часопис. 2018. № 2. С. 58-62.

6. Кравченко I. М. Громадський контроль як окремий напрям взаємодії адміністративних судів із громадськістю. Актуальні проблеми вітчизняної юриспруденщї. 2019. № 5. С. 94-98.

7. Кравчук В. М. Громадський контроль судової влади як спосіб відновлення довіри суспільства до судів та суддів. Актуальні проблеми правознавства. 2016. Вип. 3 (7). C. $11-16$.

8. Крупник А. С. Громадський контроль: сутність та механізми здійснення. URL: http://novyi-stryi.at.ua/gromkontrol/KRUPNYK_A_pro_grom_kontrol.pdf (дата звернення: 16.04.2021).

9. Наливайко Т. В. Громадський контроль в Україні як інститут громадянського суспільства: теоретико-правовий аспект : автореф. дис. ... канд. юрид. наук / Львівський державний університет внутрішніх справ. Львів, 2010. 18 с.

10. Нестор Н. В. Поняття громадського контролю за діяльністю суддів і система суб' єктів його здійснення. Право і безпека. 2019. № 2 (73). С. 43-47. 
11. Поліщук А. О. Роль громадянського суспільства у запобіганні і протидії корупції у системі правосуддя України. Актуальні проблеми держави і права. 2017. С. 120127.

12. Попова О. В. Поняття та ознаки публічної служби в Україні. Форум права. 2011. № 4. C. $583-587$.

13. Про громадський контроль : проєкт Закону України від 07.08.2018 № 9013. URL: http://w1.c1.rada.gov.ua/pls/zweb2/webproc4_1?pf3511=64506 (дата звернення: 16.04.2021).

14. Про прийняття за основу проєкту Закону України про інформаційну відкритість органів державної влади та вищих посадових осіб України : Постанова Верховної

Ради України від 17.12.2004 № 2265-IV. URL: http://zakon4.rada.gov.ua/laws/show/2265-15 (дата звернення: 17.04.2021).

15. Про судоустрій та статус суддів : Закон України від 02.06.2016 року № 1402-VIII (зі змінами та допов.). Відомості Верховної Ради Украӥни. 2016. № 31. Ст. 545.

16. Рекомендація CM/Rec (2010) 12 Комітету міністрів Ради Свропи державамчленам щодо суддів: незалежність, ефективність та обов'язки : від 17 листоп. 2010 p. URL: http://zakon5.rada.gov.ua/laws/show/994_a38 (дата звернення: 17.04.2021).

17. Рунова Н. О. Публічна служба в Україні: проблеми дефініції. Публічне право. 2012. № 3. C. 269-273.

18. Савченко О. В. Громадський контроль як вид соціального контролю: підходи до визначення поняття. Науковий вісник Херсонського державного університету. Серія: Юридичні науки. 2014. Вип. 6 (2). Т. 1. С. 44-46.

19. Хотинська-Нор О. 3. Громадський контроль як фактор розвитку судової системи. Часопис ичивільного і кримінального судочинства. 2016. № 4 (31). С. 108-117.

\section{References}

1. Entsyklopediia derzhavnoho upravlinnia : u 8 t. [Encyclopedia of public administration : 8 volumes] / nauk.-red. kolehiia: Yu. V. Kovbasiuk (holova), V. M. Kniaziev (spivholova), I. V. Rozputenko (spivholova) ta in.; Nats. akad. derzh. upr. pry Prezydentovi Ukrainy. K. : NADU, 2011. T. 1 : Teoriia derzhavnoho upravlinnia. 748 s. [in Ukrainian].

2. Zhukov, S. V. (2019). Elementnyi sklad administratyvno-pravovoho zabezpechennia dobrochesnosti suddiv. Yevropeiski perspektyvy [Elemental composition of administrative and legal support for the integrity of judges. European perspectives]. № 1. P. 29-33 [in Ukrainian].

3. Kablak, P. I. (2015). Vzaiemovidnosyny sudovoi vlady ta hromadskosti (pravovi i orhanizatsiini aspekty) [Relationship between the judiciary and the public (legal and organizational aspects)] : dys. ... kand. yuryd. nauk. Lviv. 211 s. [in Ukrainian].

4. Kodeks administratyvnoho sudochynstva: Zakon Ukrainy vid 06.07.2005 roku № 2747-IV (zi zminamy i dopov.). Vidomosti Verkhovnoi Rady Ukrainy [Code of Administrative Justice : Law of Ukraine dated 06.07.2005 № 2747-IV (with changes and supplement). Information of the Verkhovna Rada of Ukraine]. 2005. № 35-36. № 37. St. 446 [in Ukrainian].

5. Kopetiuk, M. I (2018). Administratyvnyi sud yak subiekt administratyvnoho sudochynstva. Istoryko-pravovyi chasopys [An administrative court as a subject of administrative legal proceedings. Historical and legal magazine]. № 2. S. 58-62 [in Ukrainian].

6. Kravchenko, I. M. (2019). Hromadskyi kontrol yak okremyi napriam vzaiemodii administratyvnykh sudiv iz hromadskistiu. Aktualni problemy vitchyznianoi yurysprudentsii [Public control as a separate area of interaction of administrative courts with the public. Actual problems of domestic jurisprudence]. № 5. S. 94-98 [in Ukrainian].

7. Kravchuk, V. M. (2016). Hromadskyi kontrol sudovoi vlady yak sposib vidnovlennia doviry suspilstva do sudiv ta suddiv. Aktualni problemy pravoznavstva [Public control of the judiciary as a way to restore public confidence in the courts and judges. Actual problems of jurisprudence]. Vyp. 3 (7). S. 11-16 [in Ukrainian]. 
8. Krupnyk, A. S. Hromadskyi kontrol: sutnist ta mekhanizmy zdiisnennia [Public control: the essence and mechanisms of implementation]. URL: http://novyistryi.at.ua/gromkontrol/KRUPNYK_A_pro_grom_kontrol.pdf (data zvernennia: 16.04.2021) [in Ukrainian].

9. Nalyvaiko, T. V. (2010). Hromadskyi kontrol v Ukraini yak instytut hromadianskoho suspilstva: teoretyko-pravovyi aspekt [Public control in Ukraine as an institution of civil society: theoretical and legal aspect] : avtoref. dys. ... kand. yuryd. nauk / Lvivskyi derzhavnyi universytet vnutrishnikh sprav. Lviv. 18 s. [in Ukrainian].

10. Nestor, N. V. (2019). Poniattia hromadskoho kontroliu za diialnistiu suddiv i systema subiektiv yoho zdiisnennia. Pravo $i$ bezpeka [The concept of public control over the activities of judges and the system of subjects of its implementation. Law and security]. № 2 (73). S. 43-47 [in Ukrainian].

11. Polishchuk, A. O. (2017). Rol hromadianskoho suspilstva u zapobihanni i protydii koruptsii u systemi pravosuddia Ukrainy. Aktualni problemy derzhavy i prava [The role of civil society in preventing and combating corruption in the justice system of Ukraine. Current issues of state and law]. S. 120-127 [in Ukrainian].

12. Popova, O. V. (2011). Poniattia ta oznaky publichnoi sluzhby v Ukraini. Forum prava [Concepts and features of public service in Ukraine. Law Forum]. № 4. S. 583-587 [in Ukrainian].

13. Pro hromadskyi kontrol : proiekt Zakonu Ukrainy vid 07.08.2018 № 9013 [About public control: Project of the Law of Ukraine dated 07.08.2018 № 9013]. URL: http://w1.c1.rada.gov.ua/pls/zweb2/webproc4_1?pf3511=64506 (data zvernennia: 16.04.2021) [in Ukrainian].

14. Pro pryiniattia za osnovu proiektu Zakonu Ukrainy pro informatsiinu vidkrytist orhaniv derzhavnoi vlady ta vyshchykh posadovykh osib Ukrainy : Postanova Verkhovnoi Rady Ukrainy vid 17.12.2004 № 2265-IV [On the basis of the Project of the Law of Ukraine on Information Openness of the State Authorities and Higher Educational Persons of Ukraine : Resolution of the Verkhovna Rada of Ukraine dated December 17, 2004 № 2265-IV]. URL: http://zakon4.rada.gov.ua/laws/show/2265-15 (data zvernennia: 17.04.2021) [in Ukrainian].

15. Pro sudoustrii ta status suddiv : Zakon Ukrainy vid 02.06.2016 roku № 1402-VIII (zi zminamy ta dopov.). Vidomosti Verkhovnoi Rady Ukrainy [On the judiciary and the status of judges : Law of Ukraine dated 02.06.2016 No. 1402-VIII (with changes and supplement). Information of the Verkhovna Rada of Ukraine]. 2016. № 31. St. 545 [in Ukrainian].

16. Rekomendatsiia CM/Rec (2010) 12 Komitetu ministriv Rady Yevropy derzhavamchlenam shchodo suddiv: nezalezhnist, efektyvnist ta oboviazky : vid 17 lystop. $2010 \mathrm{r}$. [Recommendation CM / REC (2010) 12 of the Committee of Ministers of the Council of Europe Member States concerning judges: independence, efficiency and duties of 17 November 2010] URL: http://zakon5.rada.gov.ua/laws/show/994_a38 (data zvernennia: 17.04.2021) [in Ukrainian].

17. Runova, N. O. (2012). Publichna sluzhba v Ukraini: problemy definitsii. Publichne pravo [Public service in Ukraine: problems of definition. Public law]. № 3. S. 269-273 [in Ukrainian].

18. Savchenko, O. V. (2014). Hromadskyi kontrol yak vyd sotsialnoho kontroliu: pidkhody do vyznachennia poniattia. Naukovyi visnyk Khersonskoho derzhavnoho universytetu. Seriia: Yurydychni nauky [Public control as a type of social control: approaches to the definition. Scientific Bulletin of Kherson State University. Series: Legal Sciences]. Vyp. 6 (2). T. 1. S. 44-46 [in Ukrainian].

19. Khotynska-Nor, O.Z. (2016). Hromadskyi kontrol yak faktor rozvytku sudovoi systemy. Chasopys tsyvilnoho i kryminalnoho sudochynstva [Public control as a factor in the development of the judicial system. Journal of Civil and Criminal Procedure]. № 4 (31). S. 108-117 [in Ukrainian]. 


\section{Holobutovskyi Roman,}

Doctor of Law

(Dnipropetrovsk State University of Internal Affairs, Dnipro)

ORCID: https://orcid.org/0000-0003-4720-9189

\section{PUBLIC CONTROL OVER THE ACTIVITIES OF PUBLIC OFFICIALS IN THE JUDICIARY}

The article describes the general characteristics of public control over the activities of public servants in the judiciary. The concepts of «public control» and «public service in the judiciary» are studied. Based on these approaches, the proposed scientifically sound definition is proposed. The normative and legal basis for exercising public control over the judiciary in Ukraine is indicated. The peculiarities of such activity are determined. Scientific provisions on the forms of public control over public servants in the judiciary are studied, including the following: sociological and statistical surveys, public hearings, public examination of acts of public authorities and their projects, publications in the press, radio, television, online publications Internet; public examination, public participation in the work of collegial authorities, inspection of the activities of any organization or responsible person, analysis of citizens' appeals, results of activities, etc. It is concluded that highquality and effective activity of the judiciary is the key to the development of a democratic, legal and social society and the state. However, in order to ensure a high level of work of this branch of government, in particular public servants in the judiciary, it is advisable to have an institution of public control, which aims to verify the objectivity and transparency of the system through various techniques and measures. It is argued that public control is in no way an instrument of coercion, with its help it is impossible to control, to order the judiciary to take certain actions. Of particular importance in this area is the issue of consolidating organizational forms of such control, but today it is not regulated by law, which necessitates the development and adoption of a special legislative act on the activities of public control entities and forms of such activities. It is determined that the issue of consolidating organizational forms of such control is of special importance in this area, but today it is not regulated by law, which necessitates the development and adoption of a special legislative act on the activities of public control entities and forms of such activities.

Key words: public; public control; court; public service; public service in judicial authorities; forms of control. 
DOI: https://doi.org/10.32366/2523-4269-2021-75-2-25-34

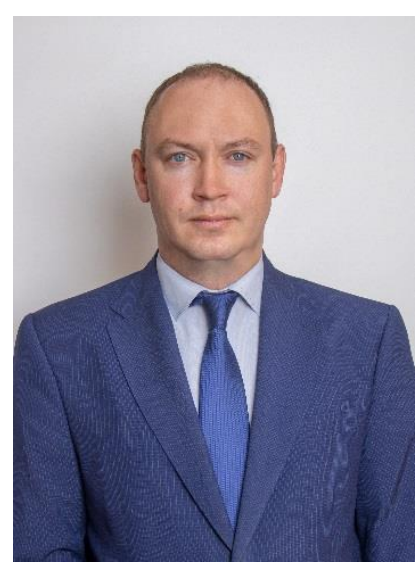

\section{Єпринцев Пилип Сергійович,}

кандидат юридичних наук, доцент

(Донецький державний університет

внутрішніх справ, м. Кривий Ріг)

ORCID: https://orcid.org/0000-0002-9790-9565

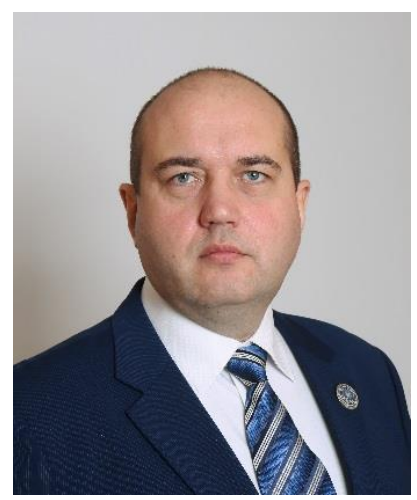

Червінчук Андрій Васильович,

кандидат юридичних наук

(Донецький державний університет

внутрішніх справ, м. Кривий Ріг)

ORCID: https://orcid.org/0000-0001-7893-6632

\section{РЕАЛІЗАЦІЯ В УКРАЇНІ ГЛОБАЛЬНИХ ЦІЛЕЙ ДЕСЯТИЛІТТЯ ДІЙ ІЗ ЗАБЕЗПЕЧЕННЯ БЕЗПЕКИ ДОРОЖНЬОГО РУХУ 2011-2020 РР.}

Статтю присвячено дослідженню питань реалізації в Украӥні глобальних иілей Десятиліття дій із забезпечення безпеки дорожнього руху 2011-2020 рр. Констатовано, щзо передумовою ухвалення резолючії Генеральної Асамблеї ООН № 64/2551, якою було проголошено проведення Десятиліття, було те, шэо відповідно до проведеного аналізу майже 1,3 мільйона людей щорічно стають жертвами дорожньо-транспортних пригод, а його метою визначено зменшення смертності від ДТП на 50 відсотків до 2020 року. Визначено ключові елементи діяльності національних $i$ місиевих органів державного управління, запропоновані у Глобальному плані проведення Десятиліття. Здійснено аналіз динаміки стану дорожньо-транспортного травматизму в Україні за 2010-2020 роки. Досліджено вплив запроваджених державою заходів на стан дорожньотранспортного травматизму $i$ з'ясовано реальні показники смертності та травматизму на автомобільних шляхах України. Доведено, щуо вжиті заходи не повною мірою відповідають змісту стратегічних рішень, щзо приймаються на міжнародному рівні. Результати запроваджених в Украӥні державних ініціатив хоч $i$ окреслили тенденцію до стабілізації дорожньо-транспортного травматизму, однак не забезпечили навіть середньоєвропейського рівня динаміки зменшення аварійності на автомобільних шляхах.

(c) Єпринцев Пилип Сергійович,

Червінчук Андрій Васильович, 2021 
Ключові слова: $\quad$ безпека дорожнього руху; дорожньо-транспортний травматизм; Десятиліття дій.

Постановка проблеми. У всьому світі понад 1,35 мільйона людей щороку втрачають життя в автомобільних аваріях, ще десятки мільйонів отримують різного ступеня травми. 3 початку 2000-х років питання безпеки дорожнього руху міжнародною спільнотою було визнано першочерговим. Організація Об’єднаних Націй (далі - ООН), Світова організація охорони здоров'я та Світовий банк поставили цю проблему на порядок денний. Керуючись цілями сталого розвитку з амбіційною метою зменшення смертності та травматизму внаслідок дорожньо-транспортних пригод (далі - ДТП) на 50 \%, Генеральною Асамблеєю ООН схвалено Глобальний план проведення Десятиліття дій із забезпечення безпеки дорожнього руху 20112020 pp. До впровадження запланованих заходів долучилася й Україна. Однак рівень смертності та травматизму внаслідок ДТП на автошляхах України залишається одним із найвищих серед європейський країн.

Аналіз останніх досліджень і публікацій. Питання забезпечення безпеки дорожнього руху неодноразово ставали предметом досліджень провідних вітчизняних ученихадміністративістів: В. Б. Авер'янова, О. Ф. Андрійко, О. М. Бандурки, В. М. Бевзенка, А. І. Берлача, Ю. П. Битяка, А. С. Васильєва, В. М. Гаращука, І. П. Голосніченка, Є. В. Додіна, Р. А. Калюжного, С. В. Ківалова, Т. О. Коломоєць, В. К. Колпакова, А. Т. Комзюка, С. Ф. Константінова, О. В. Кузьменко, Є. В. Курінного, В. І. Курила, М. В. Лошицького, Д. М. Лук'янця, Р. С. Мельника, О. М. Музичука, Н. Р. Нижник, В. І. Олефіра, О. І. Остапенка, В. П. Пєткова, С. В. Пєткова, Р. М. Пилипіва, О. П. Рябченко, С. Г. Стеценка, А. О. Собакаря, В. К. Шкарупи та інших.

Метою наукової статті $є$ визначення ефективності державної політики у сфері забезпечення безпеки дорожнього руху на основі аналізу запроваджених в Україні протягом Десятиліття дій із забезпечення безпеки дорожнього руху 2011-2020 рр. заходів, зарубіжного досвіду та реальних показників дорожньо-транспортного травматизму.

Виклад основного матеріалу. Десятиліття дій із забезпечення безпеки дорожнього руху 2011-2020 рр. (далі - Десятиліття) було проголошено 02 березня 2010 року резолюцією Генеральної Асамблеї ООН № 64/2551. Передумовою ухвалення цього важливого міжнародного документа стало те, що відповідно до проведеного аналізу майже 1,3 мільйона людей щорічно стають жертвами дорожньо-транспортних пригод. До того ж близько п'ятдесяти мільйонів людей отримують унаслідок аварій несмертельні травми, які $є$ основною причиною тимчасової непрацездатності. Дорожньо-транспортний травматизм є однією з трьох головних причин смерті осіб віком від 5 до 44 років.

Метою Десятиліття було визначено зменшення смертності від дорожньо-транспортних пригод на 50 відсотків до 2020 року [1].

Згідно з Глобальним планом здійснення Десятиліття дій із забезпечення безпеки дорожнього руху 2011-2020 pр. діяльність протягом Десятиліття має відбуватися на місцевому, національному, регіональному і глобальному рівнях, проте в центрі уваги насамперед будуть знаходитися заходи на національному та місцевому рівнях. У рамках правових механізмів національних i місцевих органів державного управління країн пропонується здійснювати діяльність за такими напрямами:

1) управління безпекою дорожнього руху - напрям, що передбачає приєднання до правових актів ООН та їх здійснення в повному обсязі, заохочення розробки регіональних актів з безпеки дорожнього руху, сприяння у створенні багатосекторальних партнерств i призначення головних установ, здатних розробити й очолити забезпечення національних стратегій, планів і цільових орієнтирів у сфері безпеки дорожнього руху, що спираються на збір даних i доказові дослідження, для оцінки організації контрзаходів і моніторингу здійснення та ефективності;

2) безпечніші дороги та мобільність - напрям, підгрунтям якого є посилення безпеки та захисних властивостей автомобільних доріг на благо всіх користувачів доріг, 
особливо найбільш вразливих з них, таких як пішоходи, велосипедисти та мотоциклісти. Це може бути досягнуто завдяки реалізації різних угод у сфері дорожньої інфраструктури в межах $\mathrm{OOH}$, проведенню оцінки дорожньої інфраструктури й удосконаленню планування, проєктування, будівництва та експлуатації доріг з урахуванням вимог безпеки;

3) безпечніші транспортні засоби - цей напрям передбачає заохочення повсюдного впровадження та вдосконалених технологій забезпечення безпеки дорожніх транспортних засобів стосовно як пасивної, так й активної безпеки шляхом гармонійного поєднання відповідних глобальних стандартів, програм інформування споживачів і стимулів для прискорення використання нових технологій;

4) безпечніша поведінка користувачів автомобільних доріг - згідно 3 цим напрямом мають бути розроблені комплексні програми поліпшення поведінки користувачів доріг, що передбачають послідовне або зростаюче забезпечення дотримання законів $\mathrm{i}$ стандартів у сфері безпеки руху в поєднанні з інформуванням та навчанням громадськості 3 метою підвищення показників користування ременями безпеки та шоломами, а також скорочення випадків керування транспортними засобами в нетверезому стані, перевищення швидкості та інших факторів ризику;

5) відповідні заходи після аварій - напрям, який передбачає підвищення оперативності реагування на екстрені ситуації, спричинені аваріями, і поліпшення здатності систем охорони здоров'я та інших систем забезпечення належної невідкладної медичної допомоги й більш тривалої реабілітації для постраждалих у ДТП [2].

Досягненню цілей Глобального плану здійснення Десятиліття дій із забезпечення безпеки дорожнього руху 2011-2020 pp. має сприяти державна політика у сфері безпеки дорожнього руху з притаманними їй формами та методами. На думку А. О. Собакаря, іiі реалізація постає водночас і як процес, і як результат науково обгрунтованої та системно організованої діяльності керівних органів держави й органів місцевого самоврядування щодо створення та вдосконалення ефективних і дієвих механізмів правового регулювання 3 подальшим втіленням у життя основних засад організації впорядкованості дорожнього руху. Вона охоплює заходи не лише правового, а й соціального, медичного, культурного, економічного та іншого характеру, і внаслідок цього передбачає участь в ії практичній реалізації широкого кола суб'єктів - центральних і галузевих органів виконавчої влади, закладів освіти, охорони здоров'я, правоохоронних органів та органів місцевого самоврядування [3].

Державне управління у сфері безпеки дорожнього руху становить організовану державою сукупність державних органів, громадських організацій, посадових осіб та окремих громадян, об'єднаних цілями та завданнями щодо забезпечення ефективного управління дорожнім рухом, мінімізації дорожньо-транспортних пригод та їх негативних наслідків, збереження життя та здоров'я учасників дорожнього руху, які здійснюють узгоджену діяльність у межах чинного законодавства України. Головною метою державного управління у сфері безпеки дорожнього руху $\epsilon$ створення ефективних державно-управлінських механізмів, що гарантовано забезпечуватимуть захист суспільства від ДТП та їх соціальних наслідків.

Державне управління у сфері забезпечення дорожнього руху, на думку Л. М. Корнути, має грунтуватися на засадах:

1) законодавчого забезпечення безпеки дорожнього руху;

2) ефективності та цілеспрямованості заходів з мінімізації дорожньо-транспортних пригод;

3) соціальної свідомості населення з питань необхідності неухильного дотримання правил дорожнього руху;

pyxy [4].

4) координації та контролю органів державної влади за станом безпеки дорожнього 
Однак нинішній стан закріплення повноважень органів державної влади у сфері забезпечення дорожнього руху не відповідає вимогам часу та своєчасності законодавчих ініціатив у сфері забезпечення безпеки дорожнього руху [5].

Як слушно зауважив В. В. Доненко, за роки незалежності в Україні сформовано відповідні нормативну базу та організаційну структуру, що забезпечують безпеку дорожнього руху. 3 моменту прийняття законів та створення організаційних структур внесено численні зміни та доповнення до чинного законодавства та у структуру й функціональну спрямованість органів, які забезпечують безпеку дорожнього руху. Здійснювалися спроби законодавця як лібералізувати, так і посилити адміністративну відповідальність за порушення у цій сфері, однак суттєвих позитивних зрушень це не дало [6].

Підсилює гостроту проблеми системна криза державної політики, що вже протягом багатьох років не дозволяє хоча б наблизитися до європейського рівня безпеки експлуатації транспортних засобів.

Прикро констатувати, що пріоритетні напрями державної політики забезпечення безпеки дорожнього руху, стратегічних орієнтирів розвитку сфери дорожньої безпеки на загальнодержавному рівні були обговорені лише на шостому році Десятиліття дій з безпеки дорожнього руху - 23 грудня 2015 року - під час парламентських слухань на тему «Стан i перспективи забезпечення в Україні безпеки дорожнього руху». Їх учасники ухвалили рекомендації Президентові України, Верховній Раді України, Кабінету Міністрів України, місцевим органам виконавчої влади та органам місцевого самоврядування. Стратегічною метою запропонованих заходів було встановлено комплексне реформування системи організації безпеки дорожнього руху в Україні, спрямованої на зменшення показників смертності та травмування людей на дорогах України до 2020 року на 30 відсотків порівняно з 2015 роком [7].

Незважаючи на визначену під час парламентських слухань особливу актуальність питань забезпечення в Україні безпеки дорожнього руху та невідкладність ухвалення управлінських рішень державного рівня, майже півтора року знадобилося Урядові України для схвалення Стратегії підвищення рівня безпеки дорожнього руху в Україні на період до 2020 року (далі - Стратегія) розпорядженням Кабінету Міністрів України від 14 червня 2017 p. № 481-p.

Головною метою Стратегії є зниження рівня смертності внаслідок ДТП щонайменше на 30 відсотків до 2020 року, ступеня тяжкості наслідків ДТП для учасників дорожнього руху та зменшення соціально-економічних втрат від дорожньо-транспортного травматизму, а також запровадження ефективної системи управління безпекою дорожнього руху для забезпечення захисту життя та здоров'я населення. Стратегія передбачає цілу низку заходів з удосконалення системи державного управління у сфері забезпечення безпеки дорожнього руху. Основними 3 них є:

$$
\text { утворення та визначення повноважень головного міжвідомчого органу з безпеки }
$$
дорожнього руху;

- $\quad$ запровадження основних засад системи управління безпекою дорожнього руху: державної програми, плану заходів, ключових складових, оцінки результатів тощо;

- удосконалення законодавства 3 питань безпеки дорожнього руху 3 метою врегулювання всіх сфер життєдіяльності та забезпечення відповідності нормативно-правової бази європейським стандартам;

- $\quad$ підвищення відповідальності злісних порушників правил дорожнього руху;

- створення єдиної національної бази даних, що об'єднує всі обліки: від отримання посвідчення водія та реєстрації транспортних засобів до накладення адміністративних стягнень;

- розроблення комплексної інформаційної системи моніторингу безпеки дорожнього руху та впровадження програм з безпеки дорожнього руху;

- $\quad$ проведення наукових досліджень у сфері дорожньої безпеки;

- $\quad$ поглиблення міжнародної співпраці у транспортній галузі; 
безпеки дорожнього руху;

- посилення ролі органів місцевого самоврядування в забезпеченні системи

- $\quad$ створення спеціального фонду з безпеки дорожнього руху та забезпечення ефективного використання його коштів;

- запровадження обов'язкового фінансування національних та регіональних програм з безпеки дорожнього руху за рахунок державного дорожнього фонду та фонду 3 безпеки дорожнього руху, ефективний розподіл ресурсів згідно з державними програмами та залучення місцевих бюджетів до виконання програм з безпеки дорожнього руху; інвалідністю;

- $\quad$ забезпечення доступності транспорту та транспортної інфраструктури для осіб 3

- $\quad$ удосконалення системи страхування у сфері безпеки дорожнього руху;

- $\quad$ підготовка фахівців з безпеки дорожнього руху, їх навчання;

- $\quad$ визначення економічної оцінки вартості втраченого життя та здоров'я, завданої економіці шкоди від дорожньо-транспортних пригод для прийняття відповідних управлінських рішень і визначення ефективності впровадження заходів з убезпечення дорожнього руху [8].

Схвалення Стратегії хоч і стало вагомим кроком на шляху досягнення успішного забезпечення безпеки дорожнього руху, однак цей крок має бути підкріплений імплементацією міжнародного досвіду в національне законодавство, адже вона дасть змогу вдосконалити реалізацію галузевих пріоритетів на національному, регіональному й місцевому рівнях, уникнути помилок, прорахунків, передбачити шляхи їх вирішення, обрати найбільш ефективні засоби для досягнення поставлених цілей та завдань [9].

План заходів щодо реалізації Стратегії підвищення рівня безпеки дорожнього руху в Україні на період до 2020 року був затверджений майже через рік, 28 березня 2018 року, рішенням Кабінету Міністрів України № 231-р, тобто за 2 роки 9 місяців до завершення Десятиліття дій з безпеки дорожнього руху. Він передбачав комплекс заходів, спрямованих на: дорожнього руху;

удосконалення системи державного управління у сфері забезпечення безпеки

- $\quad$ удосконалення ведення обліку та проведення аналізу даних стосовно дорожньотранспортних пригод;

- $\quad$ підвищення рівня безпечності доріг та дорожньої інфраструктури;

- підвищення рівня безпечності транспортних засобів;

- покращення медичного забезпечення у сфері безпеки дорожнього руху та підготовки водіїв;

- п підвищення рівня безпеки перевезення пасажирів та вантажів комерційним автомобільним транспортом;

- $\quad$ покращення безпечної поведінки учасників дорожнього руху;

- удосконалення здійснення заходів реагування та управління наслідками дорожньо-транспортних пригод;

- забезпечення дотримання Правил дорожнього руху [10].

Для реалізації зазначеного плану Постановою Кабінету Міністрів України від 25 квітня 2018 р. № 435 затверджено Державну програму підвищення рівня безпеки дорожнього руху в Україні на період до 2020 року, виконання якої мало б забезпечити:

- підвищення рівня безпеки дорожнього руху, зниження негативних наслідків (соціальних та економічних втрат і збитків) від аварійності на дорогах держави;

- $\quad$ підвищення ефективності державної системи управління безпекою дорожнього

pyxy;

- ефективне використання кадрового потенціалу та наявних технічних i фінансових ресурсів для реалізації заходів у сфері безпеки дорожнього руху; 
- покращення експлуатаційних показників автомобільних доріг і вулиць за параметрами безпечності та їх відповідність високим світовим та європейським стандартам безпеки;

- $\quad$ покращення умов руху транспортних засобів та інших учасників дорожнього руху на вулично-дорожній мережі;

- 3меншення кількості місць концентрації дорожньо-транспортних пригод та небезпечних для руху ділянок доріг;

- $\quad$ підвищення ефективності системи підготовки водіїв транспортних засобів та інших учасників дорожнього руху; відповідальності;

- $\quad$ дотримання правил дорожнього руху його учасниками, їх правової свідомості та

- $\quad$ безпеку експлуатації транспортних засобів та зменшення їх негативного впливу на довкілля, насамперед у населених пунктах;

- покращення роботи аварійно-рятувальних і медичних служб у разі настання дорожньо-транспортних пригод;

- $\quad$ належний рівень надання допомоги потерпілим у дорожньо-транспортних пригодах.

Програма передбачала залучення для іiі реалізації 7286,8491 млн гривень 3 коштів державного дорожнього фонду.

Результатом виконання Державної програми підвищення рівня безпеки дорожнього руху в Україні на період до 2020 року мало б стати зменшення кількості загиблих унаслідок дорожньо-транспортних пригод до 4 осіб на 100 тис. населення, зменшення кількості травмованих унаслідок дорожньо-транспортних пригод до 60 на 100 тис. населення та зменшення кількості загиблих унаслідок дорожньо-транспортних пригод до 9,3 осіб на 100 постраждалих [11].

Розглянувши динаміку дорожньо-транспортного травматизму в України за 2010-2020 роки, навряд чи можна вважати цілі Десятиліття досягнутими. Рівень аварійності в нашій країні залишається стабільно високим (рис.1).

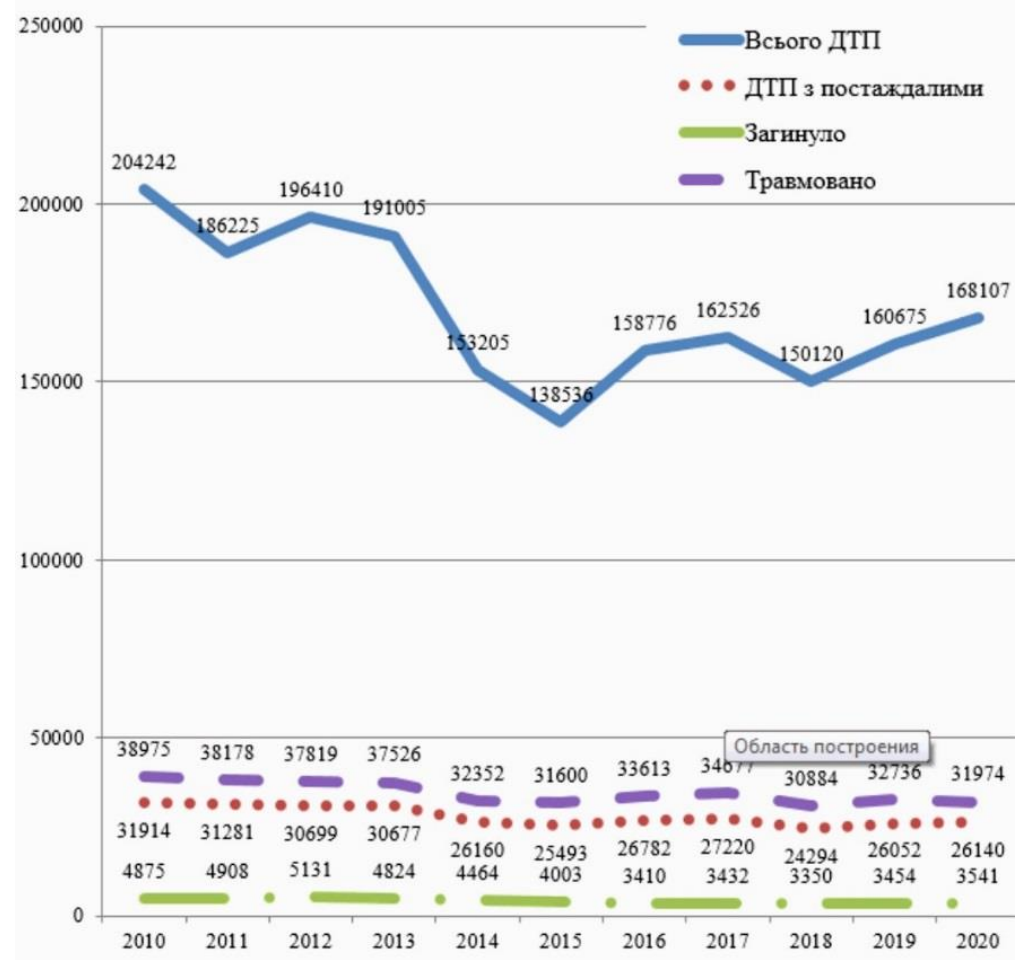

Рис.1. Динаміка стану дорожньо-транспортного травматизму в Україні за 2010-2020 роки 
Незначне зменшення облікованої кількості ДТП та постраждалих у 2014-2015 роках передусім пояснюється бойовими діями на Сході України та тимчасовою окупацією частини території нашої держави, і як наслідок - неможливістю враховувати до загальної статистики ті автопригоди, які скоєні на території окремих районів Донецької і Луганської областей та Автономної Республіки Крим. Навіть зважаючи на цей аспект, рівень смертності від ДТП за Десятиліття зменшився на 27,4 \%, тоді як глобальною ціллю було зменшення цього показника на $50 \%$.

Що ж стосується Стратегії щодо зменшення кількості загиблих на 30 \% порівняно 3 2015 роком, то за п’ятиріччя вдалося досягти зменшення смертності на автошляхах України лише на $11,5 \%$.

Не вдалося реалізувати й амбітну мету Державної програми підвищення рівня безпеки дорожнього руху в Україні на період до 2020 року - зменшення кількості загиблих унаслідок ДТП до 4 осіб на 100 тис. населення. Беручи до уваги постійне зменшення чисельності населення в Україні, цей показник становить 11,7 загиблих у ДТП на 100 тис. населення (за підсумками 2020 року) [12].

Як зазначається у Стокгольмській декларації, прийнятій за підсумками Третьої глобальної міністерської конференції з питань безпеки дорожнього руху, ціль 3.6 у сфері сталого розвитку щодо зменшення рівня смертності у ДТП не буде досягнута до 2020 року, а значний прогрес можливий тільки за умови політичного лідерства на національному рівні, глобального співробітництва, реалізації науково обгрунтованих стратегій і взаємодії з усіма відповідними сторонами, включаючи приватний сектор, та інші інноваційні підходи [13].

За підсумками Десятиліття серед європейських країн лише Греції вдалося зменшити кількість жертв на $52 \%$. Серед країн Свропейського Союзу цей показник становить у середньому $37,5 \%$.

Останнє десятиріччя продемонструвало певний прогрес у деяких країнах та регіонах, але існує нагальна потреба зробити більше, оскільки числові показники стабілізувалися, однак суттєвої тенденції до зниження поки що не спостерігається. Десятиліття дій щодо безпеки дорожнього руху (2011-2020 рр.) та цілі сталого розвитку, очевидно, помітно вплинули на країни, які вживають заходів, тому їх потрібно продовжити до 2030 р., щоб зберегти поточний рівень обізнаності.

Проте для того, щоб це відбулося протягом наступних десяти років, країнам потрібно запровадити системний підхід до безпеки дорожнього руху, збільшити потенціал та залучити кінцевих споживачів. Вони також повинні розширити свою правозастосовну діяльність, проєктувати «розумніші» дороги, продавати безпечніші транспортні засоби та проводити потужні соціальні маркетингові кампанії для підвищення обізнаності серед усіх учасників дорожнього руху [14].

Висновки. Реалізація в Україні заходів, спрямованих на досягнення глобальних цілей Десятиліття дій із забезпечення безпеки дорожнього руху 2011-2020 рр. не повною мірою відповідає змісту стратегічних рішень, що приймаються на міжнародному рівні. Результати запроваджених у країні державних ініціатив хоч і окреслили тенденцію до стабілізації дорожньо-транспортного травматизму, однак не забезпечили навіть середньоєвропейського рівня динаміки зменшення аварійності на автомобільних шляхах. Ураховуючи досвід минулого Десятиліття, необхідно впроваджувати комплексні підходи до безпеки дорожнього руху, здійснювати пошук довгострокових і стійких рішень у сфері безпеки дорожнього руху та зміцнення багатостороннього співробітництва між державним і приватним секторами, науковими колами, професійними об'єднаннями, неурядовими організаціями та засобами масової інформації з використанням сучасних вимог і технологій, які системно охоплюють усі ключові аспекти безпеки дорожнього руху, зокрема поведінку людини, дорожню інфраструктуру, конструкційну безпечність транспортних засобів, й одночасно застосовуються на етапі запобігання аварії, під час аварії та після неї відповідно до загальноприйнятих у світі підходів до формування та реалізації політики підвищення безпеки дорожнього руху. 


\section{Список використаних джерел}

1. Resolution adopted by the General Assembly on 2 March 2010 64/255. Improving global road safety. URL: https://undocs.org/en/A/RES/64/255 (дата звернення: 12.04.2020).

2. Global Plan for the Decade of Action for Road Safety 2011-2020. URL: https://www.who.int/roadsafety/decade_of_action/plan (дата звернення: 13.04.2020).

3. Собакарь А. О. Форми та методи реалізації державної політики України у сфері безпеки дорожнього руху. Науковий вісник Дніпропетровського державного університету внутрішніх справ. 2011. № 4. С. 226.

4. Корнута Л. М. Загальна характеристика концептуальних основ державного управління у сфері організації безпеки дорожнього руху. Митна справа. 2015. № 1. С. 135.

5. $\quad$ Гусаров С. М. Роль і вплив державних органів на безпеку дорожнього руху в Україні. Свропейські перспективи. 2017. № 1. С. 63.

6. Доненко В. В. Щодо системи публічного адміністрування безпеки дорожнього руху. Право і суспільство. 2012. № 4. С. 86.

7. Про схвалення Стратегії підвищення рівня безпеки дорожнього руху в Україні на період до 2020 року : розпорядження Кабінету Міністрів України від 14.06.2017 № 481-р. Урядовий кур’єр. 2017. 27 лип. (№ 138).

8. Бесчастний В. М. Актуальні питання реформування державної політики у сфері безпеки дорожнього руху. Безпека дорожнього руху: правові та організаційні аспекти: матеріали XII Міжнар. наук.-практ. конф. (в авторській редакції), м. Кривий Ріг, 17 листоп. 2017 р. Кривий Ріг, 2017. С. 22.

9. Лопатін С. В. Міжнародно-правові стандарти та досвід європейських країн у сфері правового регулювання безпеки дорожнього руху. Юридичний вісник. 2017. С. 270.

10. Про затвердження плану заходів щодо реалізації Стратегії підвищення рівня безпеки дорожнього руху в Україні на період до 2020 року : розпорядження Кабінету Міністрів України від 28.03.2018 № 231-р. Урядовий кур’єр. 2018. 14 квіт. (№ 72).

11. Про затвердження Державної програми підвищення рівня безпеки дорожнього руху в Україні на період до 2020 року : Постанова Кабінету Міністрів України від 5.04.2018 р. № 435. Урядовий кур’єр. 2018. 09 черв. (№ 108).

12. Чисельність населення та середня чисельність за періоди року. URL: http://www.ukrstat.gov.ua/operativ/operativ2020/ds/kn/kn_u/arh_kn2020_u.html (дата звернення: 14.04.2020).

13. Stockholm Declaration. URL: https://www.roadsafetysweden.com/about-theconference/stockholm-declaration (дата звернення: 15.04.2020).

14. Маргарет М Педен, Прасанті Пуваначандра. Озираючись на 10 років глобальної безпеки дорожнього руху. Міжнародне здоров'я. Том 11. Вип. 5, вересень 2019. С. 327-330. URL: https://doi.org/10.1093/inthealth/ihz042 (дата звернення: 16.04.2020).

\section{References}

1. Resolution adopted by the General Assembly on 2 March 2010 64/255. Improving global road safety. URL: https://undocs.org/en/A/RES/64/255 (data zvernennia: 12.04.2020).

2. Global Plan for the Decade of Action for Road Safety 2011-2020. URL: https://www.who.int/roadsafety/decade_of_action/plan (data zvernennia: 13.04.2020).

3. Sobakar, A. O. (2011). Formy ta metody realizatsii derzhavnoi polityky Ukrainy u sferi bezpeky dorozhnoho rukhu. Naukovyi visnyk Dnipropetrovskoho derzhavnoho universytetu vnutrishnikh sprav [Forms and methods of realization of state policy in the field of road safety. Scientific Bulletin of the Dnipropetrovsk State University of Internal Affairs]. № 4. S. 226 [in Ukrainian].

4. Kornuta, L. M. (2015). Zahalna kharakterystyka kontseptualnykh osnov derzhavnoho upravlinnia u sferi orhanizatsii bezpeky dorozhnoho rukhu. Mytna sprava [General characteristics of 
the conceptual foundations of public administration in the field of road safety organization. Customs business]. № 1. S. 135 [in Ukrainian].

5. Husarov, S. M. (2017). Rol i vplyv derzhavnykh orhaniv na bezpeku dorozhnoho rukhu v Ukraini. Yevropeiski perspektyvy [The role and influence of state authorities on road safety in Ukraine. European perspectives]. № 1. S. 63 [in Ukrainian].

6. Donenko, V. V. (2012). Shchodo systemy publichnoho administruvannia bezpeky dorozhnoho rukhu. Pravo i suspilstvo [Regarding the public administration system of traffic safety. Right and society]. № 4. S. 86 [in Ukrainian].

7. Pro skhvalennia Stratehii pidvyshchennia rivnia bezpeky dorozhnoho rukhu v Ukraini na period do 2020 roku : rozporiadzhennia Kabinetu Ministriv Ukrainy vid 14.06.2017 p. № 481-r. Uriadovyi kurier [On Approval of the Strategy for raising the level of road safety in Ukraine for the period up to 2020 : the order of the Cabinet of Ministers of Ukraine dated 14.06.2017 № 481-r. Government courier]. 2017. 27 lyp. (№ 138) [in Ukrainian].

8. Beschastnyi, V. M. (2017). Aktualni pytannia reformuvannia derzhavnoi polityky u sferi bezpeky dorozhnoho rukhu. Bezpeka dorozhnoho rukhu: pravovi ta orhanizatsiini aspekty: materialy XII Mizhnar. nauk.-prakt. konf. (v avtorskii redaktsii) [Actual issues of reforming state policy in the field of road safety. Road safety: Legal and organizational aspects : materials XII International sciences pract. a conf. (in the author's wording)], m. Kryvyi Rih, 17 lystop. $2017 \mathrm{r}$. Kryvyi Rih. S. 22 [in Ukrainian].

9. Lopatin, S. V. (2017). Mizhnarodno-pravovi standarty ta dosvid yevropeiskykh krain u sferi pravovoho rehuliuvannia bezpeky dorozhnoho rukhu. Yurydychnyi visnyk [International legal standards and experience in European countries in the field of legal regulation of road safety. Legal Bulletin]. S. 270 [in Ukrainian].

10. Pro zatverdzhennia planu zakhodiv shchodo realizatsii Stratehii pidvyshchennia rivnia bezpeky dorozhnoho rukhu v Ukraini na period do 2020 roku : rozporiadzhennia Kabinetu Ministriv Ukrainy vid 28.03.2018 № 231-r. Uriadovyi kurier [On approval of the plan of measures to implement a strategy for raising the level of road safety in Ukraine for the period up to 2020 : the order of the Cabinet of Ministers of Ukraine dated March 28, 2018 № 231-p. Government courier]. 2018. 14 kvit. (№ 72) [in Ukrainian].

11. Pro zatverdzhennia Derzhavnoi prohramy pidvyshchennia rivnia bezpeky dorozhnoho rukhu v Ukraini na period do 2020 roku : Postanova Kabinetu Ministriv Ukrainy vid 5.04.2018 r. № 435. Uriadovyi kurier [On Approval of the State Program for Raising Road Security in Ukraine for the period up to 2020 : Resolution of the Cabinet of Ministers of Ukraine from 5.04.2018 № 435. Government Courier]. 2018. 09 cherv. (№ 108) [in Ukrainian].

12. Chyselnist naselennia ta serednia chyselnist za periody roku [Population and average number for periods of the year]. http://www.ukrstat.gov.ua/operativ/operativ2020/ds/kn/kn_u/arh_kn2020_u.html (data zvernennia: 14.04.2020) [in Ukrainian].

13. Stockholm Declaration. URL: https://www.roadsafetysweden.com/about-theconference/stockholm-declaration (data zvernennia: 15.04.2020).

14. Marharet M Peden, Prasanti Puvanachandra. Ozyraiuchys na 10 rokiv hlobalnoi bezpeky dorozhnoho rukhu. Mizhnarodne zdorovia [Looking at 10 years of global road safety. International health]. Tom 11. Vyp. 5, veresen 2019. S. 327-330. URL: https://doi.org/10.1093/inthealth/ihz042 (data zvernennia: 16.04.2020) [in Ukrainian].

Epryntsev Pylyp,

$\mathrm{PhD}$ in Law, Associate Professor

(Donetsk State University of Internal Affairs, Kryvyi Rih)

ORCID: https://orcid.org/0000-0002-9790-9565 


\section{Chervinchuk Andriy,}

$\mathrm{PhD}$ in Law

(Donetsk State University of Internal Affairs, Kryvyi Rih)

ORCID: https://orcid.org/0000-0001-7893-6632

\section{IMPLEMENTATION IN UKRAINE OF THE GLOBAL GOALS OF THE DECADE OF ACTION TO ENSURE ROAD SAFETY 2011-2020}

The article is devoted to the study of the implementation of the global goals of the Decade of Action for Road Safety 2011-2020 in Ukraine. It is stated that the precondition for the adoption of the UN General Assembly resolution № 64/2551, which proclaimed the Decade, was that according to the analysis, almost 1.3 million people are victims of road accidents every year, and its goal is to reduce mortality from Accidents by 50 percent by 2020. The key elements of the activities of national and local government bodies proposed by the Global Plan for the Decade have been identified. An analysis of the dynamics of road traffic injuries in Ukraine for 2010-2020. The influence of the measures introduced by the state on the state of road traffic injuries is investigated and the real indicators of mortality and injuries on the highways of Ukraine are determined. It is established that the mortality rate from road accidents in Ukraine during the Decade decreased by $27.4 \%$, and during the implementation of the Strategy to increase road safety in Ukraine until 2020 managed to reduce mortality on Ukrainian roads by only $11.5 \%$. The ambitious goal of the State Program to increase the level of road safety in Ukraine for the period up to 2020 - reducing the number of deaths due to road accidents to 4 people per 100 thousand population - also failed to be achieved. Given the steady decline in the population of Ukraine, this figure is 11.7 deaths in road accidents per 100 thousand population in 2020. It is proved that the measures taken do not fully correspond to the content of strategic decisions taken at the international level. The results of the state initiatives introduced in Ukraine, although outlined the tendency to stabilize road traffic injuries, did not provide even the average European level of dynamics of reducing accidents on highways. The Decade of Action for Road Safety 2011-2020 and the goals of sustainable development, apparently significantly influenced countries that take measures, so they need to be continued until 2030 to maintain the current level of awareness.

Key words: road safety; road traffic injuries; decades of action.

Надіслано до редколегії 25.05.2021

Рекомендовано до публікації 27.05.2021 
DOI: https://doi.org/10.32366/2523-4269-2021-75-2-35-44

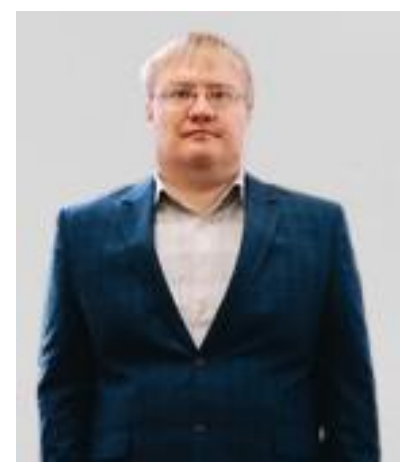

\title{
Макарчук Віталій Володимирович,
} кандидат юридичних наук

(Білочерківський національний аграрний університет, м. Біла Церква)

ORCID: https://orcid.org/0000-0002-9099-8921

\section{АДМІНІСТРАТИВНО-ПРАВОВИЙ СТАТУС ПРАВООХОРОННИХ ОРГАНІВ ЯК СУБ'СКТІВ ФОРМУВАННЯ ТА РЕАЛІЗАЦЇ̈ ДЕРЖАВНОӤ ПОЛІТИКИ У СФЕРІ НАЦІОНАЛЬНОЇ БЕЗПЕКИ І ОБОРОНИ}

\begin{abstract}
Стаття присвячена адміністративно-правовому статусу правоохоронних органів як суб'єктів формування та реалізачії державної політики у сфері національної безпеки $i$ оборони. У статті окреслено такі основні термінологічні поняття, як статус, правовий статус, адміністративно-правовий статус. Проаналізовано думки різних науковців щзодо тлумачення поняття правового статусу правоохоронних органів, його структури та елементів. Розглянуто адміністративно-правовий статус правоохоронних органів, які забезпечують формування та реалізацію державної політики у сфері національної безпеки $i$ оборони, зокрема ие адміністративно-правовий статус Національної поліції, органів прокуратури, Національного антикорупчійного бюро України, Державного бюро розслідувань, Служби правопорядку, Управління державної охорони України, органів охорони державного кордону.
\end{abstract}

Ключові слова: $\quad$ національна безпека і оборона; правоохоронні органи; суспільство; держава; державна політика; статус; правовий статус; адміністративно-правовий статус.

Постановка проблеми. Ураховуючи ситуацію, що склалася в Україні, для українського суспільства є дуже важливим питання забезпечення національної безпеки і оборони держави, що пояснюється насамперед необхідністю збереження та відновлення територіальної цілісності держави, подолання політичної та економічної кризи та дотримання прав і свобод людини і громадянина.

Держава як суб'єкт забезпечення національної безпеки і оборони сприяє формуванню та реалізації державної політики у сфері національної безпеки і оборони. Відповідно правоохоронні органи, забезпечуючи захист держави у сфері національної безпеки і оборони, призначені стримувати суспільство від учинення кримінальних правопорушень, які посягають на національну безпеку та оборону держави. Правоохоронні органи країни є ключовими в системі органів виконавчої влади та $є$ необхідною умовою захисту конституційного ладу і забезпечення законності та правопорядку, дотримання прав i свобод 
людини та громадянина й охорони внутрішньої безпеки від внутрішніх загроз.

Саме визначення адміністративно-правового статусу правоохоронних органів, що забезпечують формування та реалізацію державної політики у сфері національної безпеки і оборони, вказує на їхню роль у забезпеченні національної безпеки і оборони в державі та іiі окремих регіонах, охорони та захисту прав, свобод і законних інтересів громадян, а також допомагає протидіяти злочинності в цій сфері та підвищує ефективність діяльності відповідних суб'єктів.

Аналіз останніх досліджень і публікацій. Питання структури адміністративноправового статусу правоохоронних органів як загалом, так і окремих із них було об'єктом дослідження багатьох науковців, зокрема В. І. Бабенко, Л. М. Бахрах, Д.В.Власенко, В. К. Колпаков, Д. М. Ластович, С. П. Пономарьов та інших. Убачаємо доцільним комплексне дослідження адміністративно-правового статусу правоохоронних органів, які забезпечують формування та реалізацію державної політики у сфері національної безпеки і оборони, зокрема Національної поліції України, органів прокуратури, Національного антикорупційного бюро України, Державного бюро розслідувань, Служби правопорядку, Управління державної охорони України, органів охорони державного кордону.

Формування цілей статті (постановка завдання). Метою статті $\epsilon$ розгляд термінологічних особливостей таких понять, як «статус», «правовий статус», «адміністративно-правовий статус» та визначення структури адміністративно-правового статусу правоохоронних органів як суб'єктів формування та реалізації державної політики у сфері національної безпеки й оборони.

Виклад основного матеріалу. Перш ніж безпосередньо почати розгляд питання адміністративно-правового статусу правоохоронних органів як суб'єктів формування та реалізації державної політики у сфері національної безпеки і оборони, необхідно з'ясувати термінологічні особливості таких понять, як «статус», «правовий статус», «адміністративноправовий статус».

У перекладі з латинської «status» означає положення, стан чого-небудь або будь-кого $[1$, c. 578]. Юридична енциклопедія визначає статус як правове становище (сукупність прав та обов’язків) фізичної або юридичної особи [2, с. 626].

У філософії категорію «статус» розглядають у декількох аспектах: 1) як соціальне становище індивіда або соціальної групи в суспільстві, що визначається насамперед соціальними ознаками; 2) як сукупність прав та обов'язків індивіда або соціальної групи, яка виникає внаслідок виконання ними певної соціальної ролі, необхідної для розвитку й функціонування соціальної системи; 3) як позицію індивіда або соціальної групи, що оцінюється громадською думкою, шляхом порівняння їхнього соціального престижу [3, c. 259-260].

О. В. Зайчук та Н. М. Оніщенко зазначають, що юридичну категорію правового статусу характеризують такі ознаки: універсальний характер (правовий статус поширюється на всіх суб'єктів); правовий статус відображає індивідуальні особливості суб'єкта, його становище в системі суспільних відносин; забезпечує системність прав, свобод та обов'язків; основа правового статусу (права та обов'язки) не може реалізуватися без відповідальності; взаємозалежність елементів правового статусу; правовому статусу притаманна відносна стабільність [4, с. 366].

Варто звернути увагу на працю Б. М. Лазарєва, який наголошував, що правовий статус передбачає відповіді на питання: а) органом якого рівня $\epsilon$ цей орган: центральний, місцевий або міжтериторіальний; б) до якого виду органів належить за змістом своєї діяльності: орган влади, орган управління, правосуддя, яке офіційне найменування цього органу; в) хто його утворює, формує особовий склад; г) кому він підпорядкований, підзвітний, підконтрольний і хто може відміняти, призупиняти, змінювати й опротестовувати його акти; г) яка компетенція органу; д) хто йому підпорядкований, підзвітний, підконтрольний, чиї акти він може відміняти, призупиняти, змінювати і опротестовувати та інше; е) яка юридична сила актів 
цього органу; є) які джерела його фінансування; ж) чи наділений він правами юридичної особи [5, c. 124].

На підставі аналізу юридичної наукової літератури можемо стверджувати, що терміни «статус» та «правовий статус» вживаються щодо фізичних осіб (особа, громадянин, працівник правоохоронних органів, державний службовець, керівник), а також і щодо юридичних осіб (органи державної влади та місцевого самоврядування, об'єднання громадян, підприємства, установи, організації). Слід зауважити, що поняття «правовий статус» має загальний характер, який відображає загальні характеристики суб'єкта права (фізичної чи юридичної особи) щодо інших індивідів або органів держави в певній системі. Отже, термін «адміністративноправовий статус» є одним із видів загального поняття «правовий статус» та може бути конкретизований залежно від виду суб'єктів зазначених адміністративно-правових відносин.

А. М. Подоляка визначає, що поняття правового статусу складається iз правосуб'єктності разом з іншими правами та обов'язками, тому можна зробити висновок про складові адміністративно-правового статусу: компетенція, правозастосування, юридична відповідальність [6, с. 44].

В. Б. Авер'янов стверджував, що треба розрізняти правовий статус у широкому розумінні та у вузькому розумінні (співвідношення цілого та частини) [7, с. 156-162]. Так, компетенція (права та обов'язки) є головною складовою змісту правового статусу кожного органу, яка доповнюється такими важливими елементами: завдання, функції, характер взаємозв'язків 3 іншими органами (як «за вертикаллю», так і «за горизонталлю»), місце в ієрархічній структурі органів виконавчої влади, порядок вирішення установчих і кадрових питань тощо [7, с. 247].

Із зазначеного вище можна зробити висновок, що складова частина «статус» визначає становище, положення відповідного суб'єкта в соціальній системі, що виражається у правах та обов'язках, а елемент «правовий» вказує на те, що ці права та обов'язки містяться у відповідних нормативних актах, тобто отримали закріплення у нормах права.

Досліджуючи адміністративно-правовий статус правоохоронних органів, підтримуємо думку В. К. Колпакова, який зазначає, що адміністративно-правовий статус можна розуміти як послідовне та встановлене правове становище, що визначає конкретні особливості адміністративної діяльності правоохоронних органів як невід'ємного елементу системи державного управління, що встановлюється в законодавчих нормативно-правових актах, у сфері адміністративної діяльності правоохоронних органів [8, с. 138].

Зокрема, Л. М. Бахрах указує, що адміністративно-правовий статус державного органу складається з таких блоків: цільовий, організаційно-структурний та компетенція [9, с. 85].

Щодо зазначеного вище С. П. Пономарьов зауважує, що автором у цій структурі не враховано відповідальність і піднаглядність правоохоронних органів, які набувають особливого значення в умовах реалізації правоохоронними органами свого правового статусу $[10$, c. 123$]$.

Варто звернути увагу, що основою адміністративно-правового статусу правоохоронних органів є їхня адміністративна правосуб'єктність, тобто здатність мати права й обов'язки у сфері державного управління, це і є адміністративна правоздатність, а здатність реалізовувати надані права й обов'язки у сфері державного управління називають адміністративною дієздатністю.

Основою адміністративної діяльності є здійснення завдань і функцій контролю та нагляду за реалізацією прав та обов'язків суб'єктів правовідносин, притягнення до відповідальності осіб, винних у скоєнні правопорушень, повсякденне безпосереднє керівництво правоохоронними органами діяльністю підлеглих підрозділів, а також посадових осіб на основі й на виконання законів.

Беручи до уваги лише правоохоронні органи, слід зазначити, що характерна риса правової форми їхньої діяльності полягає в тому, що в ній найбільш чітко простежується державно-владний, виконавчо-розпорядчий, підзаконний характер повноважень правоохоронних органів [11, с. 156-161]. 
Підтримуємо думки науковців О. Є. Користіна та С. М. Бортника, які вказують, що нині актуалізація окремого й важливого напряму правоохоронної діяльності - захисту національної (економічної безпеки) - $є$ очевидною. I якщо раніше забезпечення безпеки держави передбачало передусім захист її території від зовнішнього нападу, то на сьогодні це поняття означає захист інтересів населення та держави від протиправних суспільнонебезпечних дій усередині держави. Саме цей напрям безпеки стає одним із головних у діяльності правоохоронних органів України [12, с. 118-125].

Варто також зауважити, що на формування та реалізацію державної політики у сфері національної безпеки і оборони впливає активна участь у ньому суб'єктів господарювання та самих громадян. Громадяни України реалізують національні інтереси через здійснення своїх конституційних прав та обов'язків щодо участі у виборах, референдумах, в інших формах безпосередньої демократії, у тому числі через обрані ними органи державної влади та місцевого самоврядування, здійснення інших заходів щодо забезпечення національної безпеки України, передбачених національним законодавством [13, с. 1-9].

Здійснюючи свою діяльність щодо забезпечення, формування та реалізації державної політики у сфері національної безпеки і оборони, правоохоронні органи (Національна поліція України, органи прокуратури, Національне антикорупційне бюро України, Державне бюро розслідувань, Служба правопорядку, Управління державної охорони України, органи охорони державного кордону) повинні орієнтуватися на Стратегію національної безпеки $\mathrm{i}$ оборони України від 14 вересня 2020 року. Вона визначає основні напрями державної політики у сфері національної безпеки [14].

Важливу роль у правовому та адміністративно-правовому регулюванні діяльності правоохоронних органів (Національна поліція України, органи прокуратури, Національне антикорупційне бюро України, Державне бюро розслідувань, Служба правопорядку, Управління державної охорони України, органи охорони державного кордону), які формують та реалізують державну політику у сфері національної безпеки і оборони, відіграють міжнародні акти, згода на які надана Верховною Радою України.

На думку О. М. Рєзніка, важливе місце в системі чинного національного законодавства належить підзаконним нормативним актам, які слід розуміти як акти, що видаються відповідно до закону, на підставі закону для конкретизації законодавчих розпоряджень та їх трактування або встановлення первинних норм [15, с. 489].

До того ж В.В. Ковальська наголошує на тому, що підзаконні нормативні акти забезпечують деталізацію застосування закону, регламентують порядок уведення його в дію, конкретизують механізм цієї дії, який вже визначений у законі, установлюють кількісні показники, норми, квоти, які швидко змінюються, містять рішення деяких конкретних питань, у тому числі процедурного і правоохоронного порядку [16, с. 237].

Крім того, підзаконні нормативні акти усувають недоліки чинного національного законодавства, що, безумовно, підтверджує доцільність їхнього існування.

Д. В. Власенко розглядає адміністративно-правовий статус Національної поліції України як закріплене адміністративно-правовими нормами положення зазначеного органу у взаємовідносинах внутрішнього характеру, а також із органами виконавчої влади, їхніми посадовими та службовими особами, громадськістю [17, с. 47].

Подібним є також визначення Д. М. Ластовича, який адміністративно-правовий статус Національної поліції України пропонує розуміти як визначене нормами адміністративного права його юридичне становище в механізмі держави та системі суспільних відносин [18, c. 74].

Крім того, Національна поліція України - це центральний орган виконавчої влади, який реалізує державну політику у сферах забезпечення охорони прав і свобод людини, інтересів суспільства та держави, протидії злочинності, підтримання публічної безпеки і порядку, а його діяльність спрямовується та координується урядом через міністра внутрішніх справ.

Отже, можна зробити висновок, що діяльність Національної поліції України як суб’єкта формування та реалізації державної політики у сфері національної безпеки й оборони держави 
регулюється адміністративно-правовими нормами Конституції України, міжнародних актів, законів України, зокрема нормами спеціалізованого нормативно-правового акта - Закону України «Про Національну поліцію», підзаконних актів, серед яких постанови уряду та накази Міністерства внутрішніх справ.

Діяльність органів прокуратури України як суб' єкта забезпечення національної безпеки і оборони держави регламентується нормами Конституції України.

Так, на думку В. І. Бабенко, адміністративно-правовий статус органів прокуратури утворюється врегульованим законодавством порядком створення, реорганізації, ліквідації цих органів, визначенням функцій та завдань прокуратури та наділенням їх необхідною компетенцією для виконання покладених державою прав і обов'язків. А тому в іiі статусі повинні бути закріплені цілі, завдання, функції, компетенція, організаційна структура та відповідальність [19, с. 55].

Адміністративно-правові норми, які регулюють діяльність Національного антикорупційного бюро України, містяться в Конституції України, міжнародних актах, законах і підзаконних актах, в актах Директора Національного антикорупційного бюро України, спільних актах бюро з іншими правоохоронними органами.

Здійснюючи свою діяльність у напрямку забезпечення, формування та реалізації державної політики у сфері національної безпеки й оборони, Державне бюро розслідувань (далі - ДБР) у свойй діяльності керується Законом України «Про Державне бюро розслідувань», Конституцією України, міжнародними договорами України, згода на обов'язковість яких надана Верховною Радою України, а також іншими нормативноправовими актами, прийнятими на їхній основі.

О. В. Ільченко вважає, що ДБР має складний правовий статус i належить до центральних органів виконавчої влади зі спеціальним статусом та до системи правоохоронних органів. До того ж науковець зауважує, що зазначене місце новоствореного ДБР у системі органів державної влади розширює сферу повноважень цього органу щодо антикорупційної політики і водночас може мати негативні аспекти щодо досягнення конкретних результатів діяльності ДБР [20, с. 282].

Військова служба правопорядку у Збройних силах України (далі - Служба правопорядку) як суб'єкт забезпечення національної безпеки і оборони держави призначена для забезпечення правопорядку і військової дисципліни серед військовослужбовців Збройних сил України у місцях дислокації військових частин, у військових навчальних закладах, установах та організаціях (далі - військові частини), військових містечках, на вулицях та у громадських місцях; для запобігання кримінальним та іншим правопорушенням у Збройних силах України, їх припинення; для захисту життя, здоров'я, прав і законних інтересів військовослужбовців, військовозобов'язаних під час проходження ними зборів, працівників Збройних сил України, а також для захисту майна Збройних сил України від розкрадання та інших протиправних посягань, а так само для участі у протидії диверсійним проявам i терористичним актам на військових об'єктах [21].

Отже, адміністративно-правовий статус Служби правопорядку можна тлумачити як сукупність юридично встановлених прав і обов'язків, що визначають іï місце в системі Збройних сил України, як правовий засіб (форму) розподілу діяльності зі зміцнення законності, правопорядку та військової дисципліни у Збройних силах України та забезпечення конституційних прав військовослужбовців, а повноваження - як право та можливості діяти в різних ситуаціях, відповідно до обставин, функції та завдання, спрямовані на виконання компетенції Служби правопорядку.

Головними елементами правового статусу Служби правопорядку є призначення, завдання, функції, конкретні владні повноваження і відповідальність, які є основою правового статусу.

Тому можемо зробити такий висновок, що головними елементами адміністративноправового статусу Служби правопорядку є призначення, завдання, функції, конкретні владні повноваження і відповідальність, які становлять основу правового статусу досліджуваного 
суб'єкта забезпечення законності, правопорядку, військової дисципліни та захисту конституційних прав військовослужбовців.

3 огляду на адміністративно-правовий статус Управління державної охорони України, здійснюючи свою діяльність у напрямі забезпечення, формування та реалізації державної політики у сфері національної безпеки і оборони, виконує такі завдання: здійснення державної охорони щодо органів державної влади України; забезпечення безпеки посадових осіб (визначених законом) за місцем їх перебування як на території України, так і за ії межами; забезпечення безпеки членів сімей посадових осіб, які проживають разом з ними або супроводжують їх; запобігання протиправним посяганням на посадових осіб і членів їхніх сімей та об'єкти, щодо яких здійснюється державна охорона, їх виявлення та припинення; охорони визначених об'єктів, забезпечення безпечної експлуатації транспортних засобів, призначених для посадових осіб, що охороняються; участі в заходах, спрямованих на боротьбу 3 тероризмом [22].

Виконуючи наділені державою функції стосовно забезпечення, формування та реалізації державної політики у сфері національної безпеки і оборони, органи охорони державного кордону безпосередньо виконують поставлені перед Державною прикордонною службою України завдання щодо забезпечення недоторканності державного кордону та охорони суверенних прав України в її виключній (морській) економічній зоні. Ураховуючи норми правового статусу, органам охорони державного кордону як суб'єктові забезпечення національної безпеки і оборони держави надаються відповідні повноваження: припинення будь-яких спроб незаконної зміни проходження лінії державного кордону України, здійснення прикордонного контролю і пропуску осіб та транспортних засобів через державний кордон, виявлення причин та умов, що призводять до порушень законодавства про державний кордон України, здійснення в межах своєї компетенції заходів щодо їх усунення [23].

Висновки. Адміністративно-правовий статус правоохоронних органів, що забезпечують формування та реалізацію державної політики у сфері національної безпеки і оборони, - це сукупність суб'єктивних прав i обов'язків, закріплених нормами адміністративного права за правоохоронними органами, які безпосередньо впливають на формування та реалізацію державної політики у сфері національної безпеки і оборони держави. Структура адміністративно-правового статусу правоохоронних органів України як суб'єктів забезпечення національної безпеки і оборони держави є такою: 1) мета, завдання та функції правоохоронних органів, що забезпечують національну безпеку i оборону; 2) повноваження правоохоронних органів, що забезпечують національну безпеку і оборону; 3) організаційно-штатна структура правоохоронних органів, що забезпечують національну безпеку і оборону; 4) юридичні гарантії та юридична відповідальність правоохоронних органів, що забезпечують національну безпеку і оборону.

\section{Список використаних джерел}

1. Большой юридический словарь / под ред. А. Я. Сухарева, В. Е. Крутских. Москва : ИНФРА-М, 2003. 704 с.

2. Юридична енциклопедія : у 6 т. / редкол.: Ю. С. Шемшученко та ін. Київ : Українська енциклопедія, 2003. Т. 5: П-С. 736 с.

3. Фиалковская И. Д. Сущность административного убеждения как метода государственного управления. Вестник Нижегородского университета им. Н. И. Лобачевского. 2012. № 1 (1). С. 259-264.

4. Зайчук О. В., Оніщенко Н. М. Теорія держави і права. Академічний курс : підручник. Київ : Юрінком Інтер, 2006. 688 с.

5. Лазарев Б. М. Компетенция органов управления. Москва : Юридическая литература, 1972. 472 с.

6. Подоляка А. М. Адміністративно-правовий статус Державної автомобільної інспекції МВС України : дис. ... канд. юрид. наук : 12.00.07. Харків, 2004. 204 с. 
7. Виконавча влада і адміністративне право / за заг. ред. В. Б. Авер'янова. Київ : Видавничий Дім «ІнЮре», 2002. 668 с.

8. Колпаков В. К. Адміністративне право України : підручник. Київ : ЮрінкомІнтер, 2004. $458 \mathrm{c}$.

9. Бахрах Д. Н. Административное право : учебник. Москва : Изд-во БЕК, 1997. $350 \mathrm{c}$.

10. Пономарьов С. П. Адміністративно-правовий статус органів Служби безпеки України. Право і безпека. 2012. № 3. С. 121-125.

11. Золотарьова Н. І. Форми адміністративної діяльності правоохоронних органів у сфері екологічної безпеки. Вісник НТУУ «КПІ». Політологія. Соціологія. Право. 2012. Вип. 2 (14). С. 156-161.

12. Користін О. Є., Бортник О. Є. Актуалізація окремих напрямів правоохоронної діяльності у протидії економічній злочинності. Науковий вісник Національної академії внутрішніх справ. 2013. № 4. С. 118-125.

13. Гбур 3. В. Основні функції держави у сфері забезпечення економічної безпеки. Актуальні проблеми державного управління. 2017. № 2 (25). С. 1-9.

14. Про рішення Ради національної безпеки і оборони України «Про Стратегію національної безпеки України» : Указ Президента України від 14.09.2020 р. № 392/2020. URL: https://zakon.rada.gov.ua/go/392/2020 (дата звернення: 11.05.2021).

15. Рєзнік О. М. Організаційні основи діяльності правоохоронних органів України iз забезпечення фінансово-економічної безпеки держави. Науковий вісник Міжнародного гуманітарного університету. Серія: Юриспруденція. 2018. № 34. С. 34-38.

16. Ковальська В. В. Поняття, ознаки та значення нормативно-правового акту МВС України. Форум права. 2008. № 2. С. 237-242.

17. Власенко Д. В. Адміністративно-правовий статус Національної поліції України. Национальный юридический журнал. 2016. № 5. С. 43-47.

18. Ластович Д. М. Поняття адміністративно-правового статусу поліції як суб'єкта надання поліцейських послуг. Наше право. 2015. № 6. С. 71-75.

19. Бабенко В. І. Адміністративно-правовий статус органів прокуратури України. Наше право. 2014. № 8. С. 55-57.

20. Ільченко О. В. Правові аспекти створення та діяльності Державного бюро розслідувань. Порівняльно-аналітичне право. 2017. № 4. С. 281-283.

21. Про Військову службу правопорядку у Збройних Силах України : Закон України від 07.03.2002 p. № 3099-III. URL: https://zakon.rada.gov.ua/go/3099-14 (дата звернення: 11.05.2021).

22. Управління державної охорони України. Ukrainian Military Pages. URL: https://www.ukrmilitary.com/p/department-of-state-guard-of-ukraine.html (дата звернення: 11.05.2021).

23. Про прикордонний контроль : Закон України від 05.11.2009 p. № 1710-VI. URL: https://zakon.rada.gov.ua/go/1710-17 (дата звернення: 11.05.2021). 


\section{References}

1. Suhareva, A. Ya., Krutskih, V. E. (2003). Bol'shoj yuridicheskij slovar' [Big Law Dictionary]. Moskva : INFRA-M. 704 s. [in Russian].

2. Shemshuchenko, Yu. S. (2003). Iurydychna entsyklopediia [Legal encyclopedia] : u 6 t. Kyiv : Ukrainska entsyklopediia. T. 5: P-S. 736 s. [in Ukrainian].

3. Fialkovskaya, I. D. (2012). Sushchnost' administrativnogo ubezhdeniya kak metoda gosudarstvennogo upravleniya [Essence of administrative belief as a method of government]. Vestnik Nizhegorodskogo universiteta im. N. I. Lobachevskogo. № 1 (1). S. 259-264 [in Russian].

4. Zaichuk, O. V., Onishchenko, N. M. (2006). Teoriia derzhavy i prava. Akademichnyi kurs : pidruchnyk. [Theory of state and law. Academic course : textbook]. Kyiv : Yurinkom Inter. 688 s. [in Ukrainian].

5. Lazarev, B. M. (1972). Kompetenciya organov upravleniya [Competence of governing bodies]. Moskva : Yuridicheskaya literatura. 472 s. [in Russian].

6. Podoliaka, A. M. (2004). Administratyvno-pravovyi status Derzhavnoi avtomobilnoi inspektsii MVS Ukrainy : dys. ... kand. yuryd. nauk : 12.00.07 [Administrative and legal status of the State Automobile Inspection of the Ministry of Internal Affairs of Ukraine : dissertation of the Candidate of Law Sciences : 12.00.07]. Kharkiv. 204 s. [in Ukrainian].

7. Averianov, V. B. (2002). Vykonavcha vlada i administratyvne pravo [Executive power and administrative law]. Kyiv : Vydavnychyi Dim «InIure». 668 s. [in Ukrainian].

8. Kolpakov, V. K. (2004). Administratyvne pravo Ukrainy : pidruchnyk [Administrative law of Ukraine : textbook]. Kyiv : Yurinkom-Inter. 458 s. [in Ukrainian].

9. Bahrah, D. N. (1997). Administrativnoe pravo : uchebnik. [Administrative law : textbook]. Moskva : Izd-vo BEK. 350 s. [in Russian].

10. Ponomarov, S. P. (2012). Administratyvno-pravovyi status orhaniv Sluzhby bezpeky Ukrainy. Pravo i bezpeka [Administrative and legal status of the Security Service of Ukraine. Law and security]. № 3. S. 121-125 [in Ukrainian].

11. Zolotarova, N. I. (2012). Formy administratyvnoi diialnosti pravookhoronnykh orhaniv u sferi ekolohichnoi bezpeky. Visnyk NTUU «KPI». Politolohiia. Sotsiolohiia. Pravo [Forms of administrative activity of law enforcement agencies in the field of environmental safety. Bulletin of NTUU «KPI». Politology. Sociology. Right]. № 2 (14). S. 156-161 [in Ukrainian].

12. Korystin, O. Ye., Bortnyk, O. Ye. (2013). Aktualizatsiia okremykh napriamiv pravookhoronnoi diialnosti u protydii ekonomichnii zlochynnosti. Naukovyi visnyk Natsionalnoi akademii vnutrishnikh sprav [Actualization of certain areas of law enforcement in the fight against economic crime. Scientific Bulletin of the National Academy of Internal Affairs]. № 4. S. 118-125 [in Ukrainian].

13. Hbur, Z. V. (2017). Osnovni funktsii derzhavy u sferi zabezpechennia ekonomichnoi bezpeky. Aktualni problemy derzhavnoho upravlinnia [The main functions of the state in the field of economic security. Actual problems of public administration]. № 2 (25). S. 1-9 [in Ukrainian].

14. Pro rishennia Rady natsionalnoi bezpeky i oborony Ukrainy «Pro Stratehiiu natsionalnoi bezpeky Ukrainy» : Ukaz Prezydenta Ukrainy vid 14.09.2020 r. № 392/2020 [On the decision of the National Security and Defense Council of Ukraine «On the National Security Strategy of Ukraine»]. URL: https://zakon.rada.gov.ua/go/392/2020 (data zvernennia: 11.05.2021) [in Ukrainian].

15. Rieznik, O. M. (2018). Orhanizatsiini osnovy diialnosti pravookhoronnykh orhaniv Ukrainy iz zabezpechennia finansovo-ekonomichnoi bezpeky derzhavy. Naukovyi visnyk Mizhnarodnoho humanitarnoho universytetu. Seriia: Yurysprudentsiia [Organizational bases of activity of law enforcement bodies of Ukraine on maintenance of financial and economic safety of the state. Scientific Bulletin of the International Humanities University. S.: Jurisprudence]. № 34. S. 34-38 [in Ukrainian]. 
16. Kovalska, V. V. (2008). Poniattia, oznaky ta znachennia normatyvno-pravovoho aktu MVS Ukrainy. Forum prava [The concept, features and significance of the legal act of the Ministry of Internal Affairs of Ukraine. Forum of law]. № 2. S. 237-242 [in Ukrainian].

17. Vlasenko, D. V. (2016). Administratyvno-pravovyi status Natsionalnoi politsii Ukrainy. Natsyonalnyi yurydycheskyi zhurnal [Administrative and legal status of the National Police of Ukraine. National legal journal]. № 5. S. 43-47 [in Ukrainian].

18. Lastovych, D. M. (2015). Poniattia administratyvno-pravovoho statusu politsii yak subiekta nadannia politseiskykh posluh. Nashe pravo [The concept of administrative and legal status of the police as a subject of police services. Our law]. № 6. S. 71-75 [in Ukrainian].

19. Babenko, V. I. (2014). Administratyvno-pravovyi status orhaniv prokuratury Ukrainy. Nashe pravo [Administrative and legal status of the prosecutor's office of Ukraine. Our law]. № 8. S. 55-57 [in Ukrainian].

20. Ilchenko, O. V. (2017). Pravovi aspekty stvorennia ta diialnosti Derzhavnoho biuro rozsliduvan. Porivnialno-analitychne pravo [Legal aspects of the establishment and operation of the State Bureau of Investigation. Comparative and analytical law]. № 4. S. 281-283 [in Ukrainian].

21. Pro Viiskovu sluzhbu pravoporiadku u Zbroinykh Sylakh Ukrainy : Zakon Ukrainy vid 07.03.2002 r. № 3099-III [About the Military Law Enforcement Service in the Armed Forces of Ukraine]. URL: https://zakon.rada.gov.ua/go/3099-14 (data zvernennia: 11.05.2021) [in Ukrainian].

22. Upravlinnia derzhavnoi okhorony Ukrainy [Department of State Protection of Ukraine]. Ukrainian Military Pages. URL: https://www.ukrmilitary.com/p/department-of-stateguard-of-ukraine.html (data zvernennia: 11.05.2021) [in Ukrainian].

23. Pro prykordonnyi kontrol : Zakon Ukrainy vid 05.11.2009 r. № 1710-VI [About border control]. URL: https://zakon.rada.gov.ua/go/1710-17 (data zvernennia: 11.05.2021) [in Ukrainian].

\author{
Makarchuk Vitalii, \\ $\mathrm{PhD}$ in Law \\ (Bila Tserkva National Agrarian University, Bila Tserkva) \\ ORCID: https://orcid.org/0000-0002-9099-8921
}

\title{
ADMINISTRATIVE AND LEGAL STATUS OF LAW ENFORCEMENT BODIES AS SUBJECTS OF FORMATION AND IMPLEMENTATION OF STATE POLICY IN THE FIELD OF NATIONAL SECURITY AND DEFENSE
}

The article is devoted to the administrative and legal status of law enforcement agencies as subjects of formation and implementation of state policy in the field of national security and defense. The article outlines the basic terminological concepts, such as: status, legal status, administrative and legal status. The opinions of various scholars on the interpretation of the concept of the legal status of law enforcement agencies, its structure and elements are analyzed. The administrative and legal status of law enforcement agencies that ensure the formation and implementation of state policy in the field of national security and defense, including the administrative and legal status of the National Police, Prosecutor's Office, National Anti-Corruption Bureau of Ukraine, State Bureau of Investigation, Law Enforcement Service, State Security Service of Ukraine, state border guards. It was established that the administrative and legal status is a systemic set of such administrative and legal properties of law enforcement agencies that implement state policy in the field of national security and defense, as: competence; the order of formation and acquisition of legal features; name; location; structure; goals of operation; responsibilities, which are directly regulated by current regulations, laws of Ukraine, and international agreements, the binding nature of which is given by the Verkhovna Rada of Ukraine. The presence of administrative and legal status means that law enforcement agencies have the competence defined by administrative and legal norms - subjects of 
jurisdiction, rights and responsibilities (powers), are responsible for actions or omissions within their own or delegated competence, perform public, executive, functions involved in administrative legal relations of a regulatory or protective nature. It was concluded that the administrative and legal status of law enforcement agencies (National Police, Prosecutor's Office, National Anti-Corruption Bureau of Ukraine, State Bureau of Investigation, Law Enforcement Service, State Security Service of Ukraine, state border guards) as subjects of state policy formation and implementation in sphere of national security and defense determines the main directions of influence on public relations in the state, and those that arise to protect the interests of national security and defense of the state. It was stated that the obligatory sign of acquisition by law enforcement bodies - subjects of administrativelegal status is the presence of specific subjective rights and obligations, which are realized both within the administrative legal relations and outside them.

Key words: national security and defense; law enforcement agencies; society; state; state policy; status; legal status; administrative and legal status.

Надіслано до редколегії 12.05.2021 Рекомендовано до публікації 19.05.2021 
DOI: https://doi.org/10.32366/2523-4269-2021-75-2-45-51

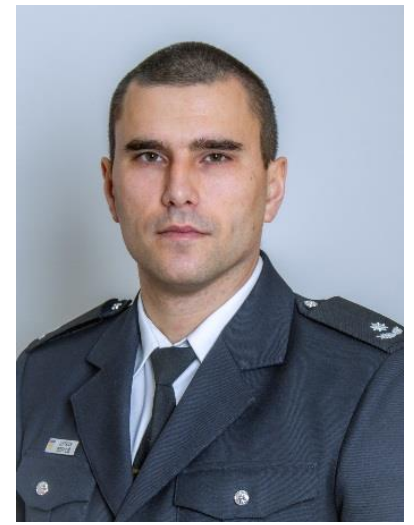

Цуркан Олексій Петрович, кандидат юридичних наук (Донецький державний університет внутрішніх справ, м. Кривий Ріг)

ORCID: https://orcid.org/0000-0002-0273-1902

\section{«ДОБІР» ЧИ «ВІДБІР» НА ПОСАДУ ПОЛІЦЕЙСЬКОГО: ДО ПИТАННЯ ВИЗНАЧЕННЯ ПОНЯТЬ}

Статтю присвячено дослідженню понять «добір» та «відбір», щุо використовуються на законодавчому рівні та під час наукових досліджень. Визначено особливості етимологічного походження та проведено розмежування термінів «добір» та «відбір». Надано пропозиції щзодо внесення змін до нормативно-правових актів 3 метою усунення прогалин у трактуванні понять.

Ключові слова:

добір; відбір; державна служба; поліџія; конкурс; кадри.

Постановка проблеми. Одним із найважливіших прийомів юридичної техніки $є$ юридична термінологія, яка передбачає застосування системи юридичних термінів у законодавстві. У юридичній літературі зазначається, що треба домогтися однозначності кожного терміна в законодавстві, прагнучи до мінімальної кількості термінів, але не доводячи, звісно, справу до втрати тих нюансів, що необхідні для практики державного управління. Термінологія повинна бути, за можливістю, стандартизована $[1$, с. 6]. Термінологічні неточності призводять до колізії норм, помилкових рішень у правозастосовній практиці [2, с. 93]. Після зміни законодавства, що визначає організаційно-правові засади служби в поліції, у Законі України «Про Національну поліцію» 3’явилися такі нові терміни, як «добір» та «відбір» осіб на службу в поліції, використання яких, на нашу думку, потребує уточнення для чіткості, зрозумілості та однозначності їх використання, що й обумовило здійснення наукового дослідження.

Аналіз останніх досліджень та публікацій. Питання «добору» та «відбору»на посади державних службовців, у тому числі в правоохоронній сфері, були предметом дослідження таких українських учених: О. М. Бандурки, В. І. Бондара, Х. З. Босак, К. Г. Гарбузюка, Н. Т. Гончарук, М. М. Дивака, О. П. Сфремової, М. А. Комзюка, А. М. Клочка, Н. П. Матюхіної, О. В. Негодченка, С. В. Сьоміна, І. Г. Сурай, В. Д. Поливанюка, В. В. Посметного, В. М. Плішкіна, О. С. Юніна та інших, однак розмежування зазначених термінів натепер усе ще залишається актуальним.

Формування цілей статті (постановка завдання). Для вирішення питання термінологічної уніфікації пропонується здійснити порівняльну характеристику понять «добір» та «відбір», чітко розмежувати визначення та особливості використання в чинному законодавстві.

Виклад основного матеріалу. Службова діяльність поліцейських, які є особами, що обіймають посади державних службовців, безумовно, неподільно пов'язана 3 нормативноправовими актами, що регламентують суспільні відносини в цій сфері. Саме тому на початку нами розглянуто деякі особливості проведення добору до лав поліції.

Так, Законом України «Про державну службу» визначено, що конкурс на зайняття посади державної служби особами, здатними професійно виконувати посадові обов'язки,

(C) Цуркан Олексій Петрович, 2021 
проводиться 3 метою «добору» (п. 1 ст. 22) [3]. Це ж саме значення зустрічаємо в п. 1 Загальних питань Порядку проведення конкурсу на зайняття посад державної служби, затверджених Постановою КМУ від 25 березня 2016 року № 246 [4].

Однак у Законі України «Про Національну поліцію» використання понять «добір» $\mathrm{i}$ «відбір» здійснюється одночасно, що, можливо, і не впливає на якість проведення конкурсу, але вносить деякі непорозуміння щодо їх застосування.

Насамперед необхідно розмежувати визначення зазначених понять, що використовуються законодавцем в розділі VI «Добір на посаду поліцейського», адже конкурс на посаду поліцейського проводиться відповідною комісією 3 метою «добору» (ст. 52), а одним із повноважень поліцейської комісії, що утворюється для забезпечення прозорого «добору» (ч. 1 ст. 51), є «проведення відбору» (ч. 4 ст. 51). У тому ж розділі йдеться про те, що під час засідання поліцейської комісії іï члени проводять «відбір» кандидатів (ч. 5 ст. 55), які проходять у встановленому порядку конкурсний «відбір» (ч. 3 ст. 55). I знову, але тепер в розділі VII «Загальні засади проходження служби в поліції», зустрічаємо порядок «добору», направлення та зарахування на навчання до вищих навчальних закладів із специфічними умовами навчання (нині - до закладів вищої освіти із специфічними умовами навчання. Прим. aвm.), які здійснюють підготовку поліцейських (ч. 6 ст. 74) [5].

Проведений системний аналіз свідчить, що за логікою викладення норм права в одних випадках термін «добір» включає в себе процедуру відбору та проведення конкурсу, а іноді використовується як синонім зазначених понять. Проте навіть узявши до уваги той факт, що поняття «добір», «конкурс» та «відбір» співвідносяться як видове і родове, вони все ж таки $\epsilon$ різними за ознаками й не можуть бути тотожними, що, у свою чергу, суперечить їх тлумаченню.

Зазначимо, що термінологічна невизначеність суперечить рішенню Конституційного Суду України від 22 вересня 2015 року, у якому, зваживши на конституційні принципи рівності і справедливості, прописана вимога щодо визначеності, ясності і недвозначності правової норми, оскільки за іншої умови не можна забезпечити ії однакове застосування, уникнути необмеженості трактування у правозастосовній практиці, що неминуче призведе до свавілля [6].

Така термінологічна підміна понять, на нашу думку, обумовлена запозиченням англомовної термінології у сферу національної законотворчої практики, адже слово «selection» має однаковий переклад українською: «добір» та «відбір».

Саме тому для уточнення потенційних розбіжностей та з метою розглянути етимологію слів «добір» і «відбір» та їхні дефініції звернулися до тлумачних словників.

Поняття «добір» [7, с. 320; 8; 9] є похідним від дії за значенням «добирати», яка, у свою чергу, передбачає таке тлумачення:

1) закінчувати брати, збирати; брати додатково до взятого, доповнювати;

2) вибираючи, знаходити найбільш відповідне:

- $\quad$ вибирати і компонувати за певним принципом, естетичними вимогами;

- $\quad$ вишукувати все необхідне для якої-небудь мети [7, с. 318; 8; 9].

Водночас термін «відбір», який використовується у законодавстві, має російськомовне походження.

Словник української мови розкриває поняття «відбір» як похідне від «відбирати»:

1) віднімати, забирати щось насильно:

- позбавляти права володіти чим-небудь, мати що-небудь;

- $\quad$ брати в когось те, що належить віддачі;

- $\quad$ брати що-небудь назад, забирати своє;

2) позбавляти когось яких-небудь якостей, властивостей, почуттів і т. ін.;

3) змушувати, заставляти витрачати час, енергію і т. ін.;

4) брати, вибирати, виділяючи із загальної маси за певною ознакою [8; 10, с. 557].

Як бачимо, поняття «відбір» має негативне стилістичне значення і позначає процес, коли відібрані речі, якості, властивості не повертаються їх «власникам». 
Як зазначає К. Г. Гарбузюк, відмінність понять «відбір» та «добір» пояснюється антонімією префіксальних морфем «від-» та «до-», яка зумовлена в основному й переважно семантикою коренів. Спільним між лексемами «відбір» та «добір»є лише словозміна кореня від дієслова «брати». «У такому разі, з огляду на антонімію префіксів у словотворенні іменників чи дієслів, використання префікса «від-» може означати виділення завдяки зменшенню чогось існуючого, а «до-» - додавання чогось існуючого завдяки збільшенню із заміщенням відсутнього. Тобто слова набувають протилежних значень як зменшеннязбільшення чи ділення-множення» [11, с. 63-64].

На жаль, у науковій літературі обидва поняття використовуються як синоніми. Автори численної кількості розвідок намагалися висвітлити своє бачення щодо роз'яснення використання зазначених понять, а отже в наукових дослідженнях сформовано різні підходи до їх розуміння саме в процесі комплектування кадрового апарату.

Розкриваючи процес «добору та відбору» кадрів на державну службу через принципи, що надають йому системного характеру, С. В. Сьомін розуміє його як процедуру диференціації людей за ступенем їхньої відповідності певному виду діяльності та прийняття рішення про придатність / непридатність кандидатів [12, с. 2].

Так, наприклад, I. Г. Сурай уважає «відбір» складовим елементом системи «добору» кадрів. Ураховуючи той факт, що «добір» кадрів (у широкому розумінні) $є$ процесом пошуку, відбору й прийняття працівників на вакантні або такі, що стануть вакантними, посади. «Добір» кадрів може проводитися на внутрішньому чи зовнішньому ринку праці, або на обох одночасно, періодично чи безперервно. На відміну від «добору», «відбір» кадрів полягає у визначенні конкретних персоналій 3 бази даних для висунення їм пропозицій щодо встановлення трудових та/або державно-службових відносин [13, с. 122-123].

При цьому авторка, посилаючись на М. Армстронга, зазначає, що процедура «добору» кадрів включає три стадії:

1) визначення вимог - підготовка посадових інструкцій і переліків вимог до кандидатів; ухвалення рішення про умови зайнятості;

2) залучення кандидатів - огляд та оцінка внутрішніх і зовнішніх джерел залучення кандидатів, розміщення оголошень про набір, звернення до агентств і консультантів;

3) відбір кандидатів - ретельний аналіз анкет, проведення співбесід, тестування, оцінка кандидатів, робота центру оцінювання, пропозиція щодо найму, отримання рекомендацій; підготовка трудового договору [14, с. 50].

Відбір, за твердженням В. І. Бондара, дозволяє не просто «набрати» кадри на службу до правоохоронних органів, а саме відібрати кращих із кращих, що, у свою чергу, дає змогу забезпечити ефективне виконання ними своїх завдань та функцій $[15$, с. 65$]$.

До системи «добору» кадрів державної служби України I. Г. Сурай відносить: визначення вимог для претендентів на конкретні вакантні посади державної служби; огляд та оцінку внутрішніх і зовнішніх джерел залучення кандидатів, розміщення оголошень про набір; конкурсний відбір; прийняття на посади поза конкурсом (за іншою процедурою, передбаченою чинним законодавством: система переведення; призначення на посаду; система обрання; за контрактом); формування кадрового резерву; стажування; оцінку кадрів [13, c. 122-123].

Підтримуючи необхідність розмежування понять «добір» та «відбір», К. Г. Гарбузюк зазначає, що вживання понять «добір» та «відбір» як тотожних або нетотожних у використаних словосполученнях, викладених в Законі України «Про Національну поліцію», поєднують в собі «відбір», «конкурс» та «атестацію», а іноді навіть є синонімами терміна «конкурс». Саме тому автор висловлює думку щодо необхідності звернення до законодавчої практики застосування терміна «відбір» [11, с. 65-68]. Однак, враховуючи семантику вживання зазначеної термінології, не погоджуємося 3 позицією науковця і наголошуємо на факті застосування цих понять у різних значеннях, а тому наполягаємо на необхідності використання поняття «добір». 
На відміну від позиції К. Г. Гарбузюка, А. М. Клочко стверджує, що поняття «добір» і «відбір» $є$ синонімами, посилаючись на словник синонімів, та наголошує, що поділ цих слів неможливий [16, с. 184].

Н. Т. Гончарук, I. Г. Сурай зауважують, що у широкому розумінні «добір кадрів» - це процес пошуку, «відбору» та прийняття працівників на вакантні або такі, що стануть вакантними, посади. Кінцева мета цього процесу полягає в тому, щоб з мінімальними витратами найняти певну кількість працівників відповідної якості для задоволення потреб організації (установи) у кадрах [17, с. 159].

Таким чином, здійснення аналізу законодавчих та наукових джерел дає можливість стверджувати про наявність одночасного вживання понять «добір» та «відбір». Ураховуючи антонімію префіксальних морфем «до-» та «від-» і той факт, що поняття «добір» і «відбір» не можуть бути визначені як синоніми, а також сталу позицію Конституційного Суду України, наголошуємо на необхідності обов'язкового використання поняття «добір».

Висновки. На підставі викладеного вище повністю погоджуємося із беззаперечним застосуванням європейського (за своїм змістом) підходу до проведення саме «добору» на службу в Національну поліцію України. Проведений аналіз наукових праць дав змогу акцентувати увагу на тому, що поняття «відбір» повинно розглядатися виключно як складова процесу добору на посаду поліцейського. Поняття «добір» має більш змістовне й узагальнене значення, що вказує на необхідність саме його використання в законодавстві. 3 огляду на це цілком логічним вважаємо необхідність застосування більш змістовного поняття «добір» як під час наукових досліджень, так і в законотворчій практиці, а також пропонуємо внести зміни до Закону України «Про Національну поліцію» шляхом подальшого вилучення поняття «відбір» та заміною останнього на поняття «добір».

\section{Список використаних джерел}

1. Лазарев Б. М. Компетенция органов управления. М. : Юрид. лит., 1972. 280 с.

2. Морозова Л. А. Юридическая техника: обзор материалов научно-методического семинара. Государство и право. 2000. № 12. С. 85-98.

3. Про державну службу : Закон України від 10.12.2015 р. № 889-VIII. Biдомості Верховної Ради України. 2016. № 4. Ст. 60.

4. Про порядок проведення конкурсу на зайняття посад державної служби : Розпорядження КМУ України від 25 березня 2016 р. № 246. Офіиіийний вісник Украйни. 2016. № 28. Ст. 1116.

5. Про Національну поліцію : Закон України від 02 липня 2015 року № 580-VIII. Відомості Верховної Ради Украӥни. 2015. № 40-41. Ст. 379.

6. Рішення КСУ від 22 вересня 2005 року № 5-рп/2005 у справі № 1-17/2005 за конституційним поданням 51 народного депутата України щодо відповідності Конституції України (конституційності) положень статті 92. URL: https://zakon.rada.gov.ua/laws/show/v005p710-05\#Text (дата звернення: 21.03.2021).

7. Словник української мови : в 11 т. / ред. кол.: І. К. Білодід (голова) та ін.; АН Української РСР, Ін-т мовознав. ім. О. О. Потебні. Київ : Наук. думка,1970-1980. Т. 2 : Г-Ж / ред. тому: П. П. Доценко, Л. А. Юрчук. 1971. 550 с.

8. Словник української мови. Академічний тлумачний словник (1970-1980). URL: http://sum.in.ua/s/dobir (дата звернення: 18.03.2021).

9. Словник UA. Портал української мови та культури. URL: https://slovnyk.ua/index.php?swrd=\%D0\%B4\%D0\%BE\%D0\%B1\%D1\%96\%D1\%80\#: :text=\%5E $\% 20 \% \mathrm{D} 0 \% 9 \mathrm{~F} \% \mathrm{D} 1 \% 80 \% \mathrm{D} 0 \% \mathrm{~B} 8 \% \mathrm{D} 1 \% 80 \% \mathrm{D} 0 \% \mathrm{BE} \% \mathrm{D} 0 \% \mathrm{~B} 4 \% \mathrm{D} 0 \% \mathrm{BD} \% \mathrm{D} 0 \% \mathrm{~B} 8 \% \mathrm{D} 0 \% \mathrm{~B} 9 \% 20$ $\% \mathrm{D} 0 \% \mathrm{~B} 4 \% \mathrm{D} 0 \% \mathrm{BE} \% \mathrm{D} 0 \% \mathrm{~B} 1, \% \mathrm{D} 0 \% \mathrm{BD} \% \mathrm{D} 0 \% \mathrm{~B} 0 \% 20 \% \mathrm{D} 0 \% \mathrm{BE} \% \mathrm{D} 1 \% 81 \% \mathrm{D} 0 \% \mathrm{BD} \% \mathrm{D} 0 \% \mathrm{BE} \%$ D0\%B2\%D1\%96\%20\%D1\%81\%D0\%BF\%D0\%B0\%D0\%B4\%D0\%BA\%D0\%BE\%D0\%B2\%D0 $\%$ BE\%D $1 \% 81 \% \mathrm{D} 1 \% 82 \% \mathrm{D} 1 \% 96 \% 20 \% \mathrm{D} 1 \% 96 \% 20 \% \mathrm{D} 0 \% \mathrm{BC} \% \mathrm{D} 1 \% 96 \% \mathrm{D} 0 \% \mathrm{BD} \% \mathrm{D} 0 \% \mathrm{BB} \% \mathrm{D} 0$ $\% \mathrm{~B} 8 \% \mathrm{D} 0 \% \mathrm{~B} 2 \% \mathrm{D} 0 \% \mathrm{BE} \% \mathrm{D} 1 \% 81 \% \mathrm{D} 1 \% 82 \% \mathrm{D} 1 \% 96$ (дата звернення: 18.03.2021). 
10. Словник української мови : в 11 т. / ред. кол.: І. К. Білодід (голова) та ін.; АН Української РСР, Ін-т мовознав. ім. О. О. Потебні; Київ : Наук. думка. 1970-1980. Т. 1: А-В / ред. тому: П. Й. Горецький та ін. 1970.799 с.

11. Гарбузюк К. Г. Адміністративно-правове забезпечення відбору кандидатів на службу в Національну поліцію : дис. ... канд. юрид. наук. Львів, 2016. 266 с.

12. Сьомін С. В., Стрілець М. І. Система управління якістю в органах державної влади : рекрутингова кадрова робота (на прикладі Французької Республіки). Державне управління: теорія та практика : електрон. наук. фах. вид. 2008. № 2. С. 1-9.

13. Сурай І. Г. Добір кадрів. Енциклопедія державного управління : у 8 т. / наук.ред. колегія : Ю. В. Ковбасюк (голова) та ін.; Нац. акад. держ. упр. при Президентові України. К. : НАДУ, 2011. Т. 6 : Державна служба / наук. ред. колегія: С. М. Серьогін (співголова), В. М. Сороко (співголова) та ін. 2011. С. 122-123.

14. Сурай I. Г. Добір і відбір кадрів як механізм формування й розвитку еліти в державному управлінні. Збірник наукових праџь Наџіональної академії державного управління при Президентові Украӥни / за заг. ред. Ю. В. Ковбасюка. К. : НАДУ, 2012. Вип. 2. С. 47-53.

15. Бондар В. І. До проблеми кадрового відбору на службу до правоохоронних органів. Прикарпатський юридичний вісник. 2018. Випуск 2 (23). Том 2. С. 65-68.

16. Клочко А. М. Кадрове забезпечення органів внутрішніх справ України: адміністративно-правові засади організації та функціонування : дис. ... доктора юрид. наук : 12.00.07. Харків, 2012. 481 с.

17. Гончарук Н. Т., Сурай I. Г. Добір як кадрова технологія формування управлінської еліти: досвід Франції. Актуальні проблеми європейської та євроатлантичної інтеграції України : матеріали 8-ї регіон. наук.-практ. конф. (м. Дніпропетровськ, 19 трав. 2011 р.) / за заг. ред. Л. Л. Прокопенка. Дніпропетровськ : ДРІДУ НАДУ. 2011. С. 159-161.

\section{References}

1. Lazarev, B. M. (1972). Kompetentsyia orhanov upravlenyia [Competence of the authorities]. M. : Yuryd. lyt. 280 c. [in Russian].

2. Morozova, L. A. (2000).Yurydycheskaia tekhnyka : obzor materyalov nauchnometodycheskoho semynara [Legal appliances: Review of the materials of the scientific and methodological seminar]. Hosudarstvo y pravo. № 12. S. 85-98 [in Russian].

3. Pro derzhavnu sluzhbu : Zakon Ukrainy vid 10.12.2015 r. № 889-VIII [About the service : Law of Ukraine vid 10.12.2015 r. № 889-VIII]. Vidomosti Verkhovnoi Rady Ukrainy. 2016. № 4. St. 60 [in Ukrainian].

4. Pro poriadok provedennia konkursu na zainiattia posad derzhavnoi sluzhby : Rozporiadzhennia KMU Ukrainy vid 25 bereznia 2016 r. № 246 [On the procedure for conducting a competition for the position of civil service : the Order of the Cabinet of Ministers of Ukraine dated March 25, 2016 № 246]. Ofitsiinyi visnyk Ukrainy. 2016. № 28. St. 1116 [in Ukrainian].

5. Pro Natsionalnu politsiiu : Zakon Ukrainy vid 02 lypnia 2015 roku № 580-VIII [About the National Police : Law of Ukraine of July 02, 2015 No. 580-VIII]. Vidomosti Verkhovnoi Rady Ukrainy. 2015. № 40-41. 1970 s. [in Ukrainian].

6. Rishennia KSU vid 22 veresnia 2005 roku № 5-rp/2005 u spravi № 1-17/2005 za konstytutsiinym podanniam 51 narodnoho deputata Ukrainy shchodo vidpovidnosti Konstytutsii Ukrainy (konstytutsiinosti) polozhen statti 92 [The decision of the CCU of September 22, 2005 № 5RP / 2005 in the case № 1-17/2005 under the constitutional representation of the 51 People's

Deputy of Ukraine regarding compliance with the Constitution of Ukraine (constitutionality) of the provisions of Article 92]. URL: https://zakon.rada.gov.ua/laws/show/v005p710-05\#Text (data zvernennia: 21.03.2021) [in Ukrainian].

7. Slovnyk ukrainskoi movy : v 11 t. [Ukrainian Dictionary : in 11 volumes] / red. kol.: I. K. Bilodid (holova) ta in.; AN Ukrainskoi RSR, In-t movoznav. im. O. O. Potebni. Kyiv : Nauk. 
dumka. 1970-1980. T. 2 : H-Zh / red. tomu: P. P. Dotsenko, L. A. Yurchuk. 1971. $550 \mathrm{~s}$. [in Ukrainian].

8. Slovnyk ukrainskoi movy. Akademichnyi tlumachnyi slovnyk (1970-1980) [Dictionary of the Ukrainian language. Academic Bloc (1970-1980)]. URL: http://sum.in.ua/s/dobir (data zvernennia: 18.03.2021) [in Ukrainian].

9. Slovnyk UA. Portal ukrainskoi movy ta kultury [Dictionary UA. The portal of the Ukrainian language and culture]. URL: https://slovnyk.ua/index.php?swrd=\%D0\%B4\%D0\%BE\%D0\%B1\%D1\%96\%D1\%80\#: :text=\%5E \%20\%D0\%9F\%D1\%80\%D0\%B8\%D1\%80\%D0\%BE\%D0\%B4\%D0\%BD\%D0\%B8\%D0\%B9\%20 $\% \mathrm{D} 0 \% \mathrm{~B} 4 \% \mathrm{D} 0 \% \mathrm{BE} \% \mathrm{D} 0 \% \mathrm{~B} 1, \% \mathrm{D} 0 \% \mathrm{BD} \% \mathrm{D} 0 \% \mathrm{~B} 0 \% 20 \% \mathrm{D} 0 \% \mathrm{BE} \% \mathrm{D} 1 \% 81 \% \mathrm{D} 0 \% \mathrm{BD} \% \mathrm{D} 0 \% \mathrm{BE} \%$ D0\%B2\%D1\%96\%20\%D1\%81\%D0\%BF\%D0\%B0\%D0\%B4\%D0\%BA\%D0\%BE\%D0\%B2\%D0 $\% \mathrm{BE} \% \mathrm{D} 1 \% 81 \% \mathrm{D} 1 \% 82 \% \mathrm{D} 1 \% 96 \% 20 \% \mathrm{D} 1 \% 96 \% 20 \% \mathrm{D} 0 \% \mathrm{BC} \% \mathrm{D} 1 \% 96 \% \mathrm{D} 0 \% \mathrm{BD} \% \mathrm{D} 0 \% \mathrm{BB} \% \mathrm{D} 0$ $\% \mathrm{~B} 8 \% \mathrm{D} 0 \% \mathrm{~B} 2 \% \mathrm{D} 0 \% \mathrm{BE} \% \mathrm{D} 1 \% 81 \% \mathrm{D} 1 \% 82 \% \mathrm{D} 1 \% 96$ (data zvernennia: 18.03.2021) [in Ukrainian].

10. Slovnyk ukrainskoi movy : v 11 t. [Ukrainian Dictionary : in 11 volumes] / red. kol.: I. K. Bilodid (holova) ta in.; AN Ukrainskoi RSR, In-t movoznav. im. O. O. Potebni. Kyiv : Nauk. dumka. 1970-1980. T. 1 : A-V / red. tomu: P. I. Horetskyi ta in. 1970. 799 s. [in Ukrainian].

11. Harbuziuk, K. H. (2016). Administratyvno-pravove zabezpechennia vidboru kandydativ na sluzhbu v Natsionalnu politsiiu [Administrative and legal support for the selection of candidates for service to the national police] : dys. ... kand. yuryd. nauk. Lviv. $266 \mathrm{~s}$. [in Ukrainian].

12. Somin, S. V., Strilets, M. I. (2008). Systema upravlinnia yakistiu v orhanakh derzhavnoi vlady: rekrutynhova kadrova robota (na prykladi Frantsuzkoi Respubliky) [Quality management system in public authorities: Recruiting personnel work (on the example of the French Republic)]. Derzhavne upravlinnia: teoriia ta praktyka : elektron. nauk. fakh. vyd. № 2. S. 1-9 [in Ukrainian].

13. Surai, I. H. (2011). Dobir kadriv. Entsyklopediia derzhavnoho upravlinnia : u 8 t. [Selection of frames. Encyclopedia of Public Administration: 8 volumes]. Nats. akad. derzh. upr. pry Prezydentovi Ukrainy; nauk.-ped. kolehiia: Yu. V. Kovbasiuk (holova) ta in. K. : NADU. 2011. T. 6 : Derzhavna sluzhba. nauk. red. kolehiia : S. M. Serohin (spivholova), V. M. Soroko (spivholova) ta in. S. 122-123 [in Ukrainian].

14. Surai, I. H. (2012). Dobir i vidbir kadriv yak mekhanizm formuvannia y rozvytku elity $\mathrm{v}$ derzhavnomu upravlinni [Selection and selection of frames as a mechanism for the formation and development of the elite in public administration]. Zbirnyk naukovykh prats Natsionalnoi akademii derzhavnoho upravlinnia pry Prezydentovi Ukrainy / za zah. red. Yu. V. Kovbasiuka. K. : NADU. Vyp. 2. S. 47-53 [in Ukrainian].

15. Bondar, V. I. (2018). Do problemy kadrovoho vidboru na sluzhbu do pravookhoronnykh orhaniv [To the problem of personnel selection for law enforcement]. Prykarpatskyi yurydychnyi visnyk. Vypusk 2 (23). Tom 2. S. 65-68 [in Ukrainian].

16. Klochko, A. M. (2012). Kadrove zabezpechennia orhaniv vnutrishnikh sprav Ukrainy: administratyvno-pravovi zasady orhanizatsii ta funktsionuvannia [Personnel provision of bodies of internal affairs of Ukraine: administrative and legal principles of organization and functioning] : dys. ... doktora yuryd. nauk : 12.00.07. Kharkiv. 481 s. [in Ukrainian].

17. Honcharuk, N. T. (2011).Dobir yak kadrova tekhnolohiia formuvannia upravlinskoi elity: dosvid Frantsii [Selection as a personnel technology of forming a management elite: the experience of France]. Aktualni problemy yevropeiskoi ta yevroatlantychnoi intehratsii Ukrainy : materialy 8-yi rehion. nauk.-prakt. konf. (Dnipropetrovsk, 19 trav. 2011 r.) / za zah. red. L. L. Prokopenka. Dnipropetrovsk : DRIDU NADU. S. 159-161 [in Ukrainian].

\section{Tsurkan Oleksiy,}

$\mathrm{PhD}$ in Law

(Donetsk State University of Internal Affairs, Kryvyi Rih)

ORCID: https://orcid.org/0000-0002-0273-1902 


\section{SELECTION FOR POLICE OFFICERS DUTY: THE QUESTION OF THE DEFINITIONS}

The level of trust of police service depends on objectively transparent and unprejudiced requirements. That's why we agree with necessity of using of the European approach in conducting «selection» for the duty in the National Police of Ukraine. It is because the main aim of creating a fundamentally new structure of the modern police of Ukraine starts directly with the selection for the service and be in accordance with European terms. The one of the most approaches of translation of legal terminology is the using of a system of law terms. There is mention in the jurisprudence that very necessary to achieve unambiguity of each term in the law texts and legislation. It is striving for the minimum required number of terms, but with the losing of those nuances that are necessary for public administration practice. The article focuses on the differences of the translation definitions of word «selection» that used in Ukrainian law texts and researches. Some researchers revealing the process of «selection» of personnel through the principles of systemic character as a procedure of differentiation staff according to their compliance with a certain type of activity and making the decision on the suitability or unsuitability of candidates. The author determinate etymological origin of the concepts «selection» in Ukrainian and differentiate the using of their translation. The research papers make a suggestion to putting forward changes in legal acts with the propose of remove the inaccuracy in the interpretation concepts. The system of «selection» of the staff of the civil service of Ukraine includes: defining the requirements for applicants for specific vacancy positions of the civil service; review and evaluation of internal and external sources of attraction of candidates, placement of ads on a set; competitive selection; acceptance for positions outside the competition (according to another procedure provided by the current legislation: the transfer system; appointment to the post; selection system; by contract); formation of personnel reserve; internship; assessment of frames. The notion of «selection» has a more meaningful and widespread value, indicating the need for its use in the legislation.

Key words: selection; state service; contest; police; staff.

Надіслано до редколегії 13.04.2021

Рекомендовано до публікації 20.04.2021 
УДК: 338.2:351

DOI: https://doi.org/10.32366/2523-4269-2021-75-2-52-59

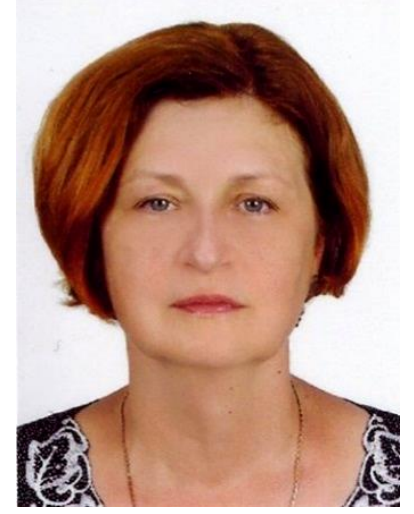

Шеховцова Вікторія Володимирівна, кандидат економічних наук (Донецький державний університет внутрішніх справ, м. Кривий Ріг)

ORCID: https://orcid.org/0000-0002-2207-9317

\section{СУЧАСНЕ БАЧЕННЯ ПРИРОДИ БЕЗПЕКИ ІНТЕЛЕКТУАЛЬНОЇ ВЛАСНОСТІ ПІДПРИЕМСТВ УКРАЇНИ}

Статтю присвячено дослідженню питань економічної сутності та природи безпеки інтелектуальної власності. Автором розглянуто такі категорії, як «інтелектуальна власність», «безпека інтелектуальної власності» та «право інтелектуальної власності». Проаналізовано принципи інтелектуальної власності та охарактеризовано систему прав інтелектуальної власності України. Визначено основні загрози, щчо можуть вплинути на ефективність функиіонування системи безпеки інтелектуальної власності. Запропоновано можливі шляхи зміцнення рівня безпеки інтелектуальної власності.

Ключові слова:

економічна безпека; безпека інтелектуальної власності; загрози інтелектуальній безпеці власності; право інтелектуальної власності.

Постановка проблеми. Економічна та політична нестабільність в Україні актуалізує проблеми забезпечення системи економічної безпеки підприємств держави. За умов невизначеності управлінський апарат кожного підприємства першочерговим визначає завдання сформувати достатньо розвинену систему економічної безпеки власного бізнессередовища. Унормоване управління елементами економічної безпеки забезпечує стабільність функціонування кожного підрозділу суб'єкта господарської діяльності. У цьому разі мова йтиме про одну 3 функціональних складових економічної безпеки підприємства інтелектуальну безпеку власності. Інтелектуальна власність - це результат творчої діяльності будь-якої людини, групи людей чи колективу.

Необхідно зауважити, що економіка швидкими темпами інтелектизується. Саме 3 цієї причини інтелектуальна безпека власності є однією з головних складових системи економічної безпеки як на рівні держави, так і на рівні системи економічної безпеки підприємства.

Актуальність дослідження полягає в тому, щоб на підставі проблемних питань щодо удосконалення системи інтелектуальної безпеки власності визначити основні напрями подолання інтелектуальної кризи, реалізації інтелектуального потенціалу, створення правових механізмів захисту об’єктів інтелектуальної власності.

Аналіз основних досліджень та публікацій. Більшість вітчизняних науковців приділяють увагу питанням безпеки інтелектуальної власності, досліджуючи різні аспекти системи економічної безпеки підприємств. Зважаючи на актуальність, варто наголосити на наукових доробках таких відомих учених, як Т. Васильців, О. Ілляшенко, О. Ляшенко, 
О. Сороківська та інші. У працях багатьох українських дослідників проаналізовано практичні аспекти складових системи економічної безпеки підприємства. Серед них можна виділити публікації О. Орлика [1], Ю. Ярової та Л. Артеменко [2]. Авторами розглянуто оцінювання структури економічної безпеки підприємства та їі складових, а також класифікацію загроз безпеки.

3 точки зору методології безпосередньо питання системи інтелектуальної безпеки підприємства висвітлювали І. Дубровіна, О. Марченко, А. Мокій, Н. Себерякова та інші. Однак у наукових вітчизняних виданнях економічного напрямку не сформовано єдиного підходу до визначення поняття «безпека інтелектуальної власності підприємства».

Право інтелектуальної власності $\epsilon$ об'єктом вивчення таких дослідників, як А. Аксютіна, Г. Андрощук, О. Бутнік-Сіверський, В. Дроб'язко, Р. Дроб'язко, Р. Еннан, О. Нестерцова-Собакарь, В. Тропін та багато інших. Зокрема, В. Дроб'язко та Р. Дроб'язко приділяли увагу історії права інтелектуальної власності. За визначенням авторів, термін «право інтелектуальної власності» 3'явився у французькому законодавстві наприкінці XVIII ст. Основою права інтелектуальної власності того часу була теорія природного права, яку досліджували французькі філософи-просвітителі: Вольтер, Дідро, Гольбах, Гельвецій, Руссо.

У ХХ ст., а саме у 1967 р., у Стокгольмі була підписана Конвенція про заснування Всесвітньої організації інтелектуальної власності (далі - Конвенція). Згідно зі ст. 2 цієї Конвенції термін «інтелектуальна власність» визначено як права щодо конкретних результатів творчої діяльності у виробничій, науковій та художній сферах. У нашій державі право інтелектуальної власності має свою історію та передумови виникнення [3].

А. Аксютіна, О. Нестерцова-Собакарь та В. Тропін указують на те, що інтелектуальна власність зараз охороняється в більшості країн світу і $є$ одним з найважливіших стимуляторів прогресу суспільства в усіх галузях розвитку. Так, психологи вивчають іï як результат розумової праці людини. Для економістів інтелектуальна власність - це можливість підвищити рівень ефективності виробництва. Правознавці вбачають у ній суспільну цінність $і$ об’єкт права [4].

До того ж деякі фахівці вважають право інтелектуальної власності комплексною галуззю вітчизняного законодавства, а інші - самостійною. Так, О. Орлюк зазначає, що наше законодавство у сфері інтелектуальної власності є комплексною галуззю законодавства. Тому для права інтелектуальної власності характерним $є$ використання прийомів і способів, що властиві іншим галузям права (цивільному, господарському, кримінальному, адміністративному, митному, податковому тощо) [5]. Р. Еннан має свою позицію щодо природи права інтелектуальної власності. Науковець стверджує, що право інтелектуальної власності є самостійною комплексною галуззю права, яка регулює суспільні відносини в інтелектуальній сфері діяльності людини [6].

У юридичній літературі стосовно питань інтелектуальної власності подано різні визначення поняття «право інтелектуальної власності». Із суб'єктивної точки зору - це суб' єктивне право, а з об'єктивної - цивільно-правовий інститут, сукупність правових норм, які регулюють відносини в системі створення та охорони інтелектуальної власності.

Позитивним є збільшення спеціалізованої літератури та видань у сфері інтелектуальної власності. Але проблеми все ж існують. Роль і значення інтелектуальної власності у всьому світі постійно зростають. Інтелектуальні досягнення суспільства сприяють науковому, технічному та культурному прогресу. Попри розгалужену структуру організації державного управління сферою інтелектуальної власності, остання не розвивається. Відсутність належного фінансування насамперед гальмує розвиток сфери інтелектуальної власності.

Більшість законодавчих та нормативних актів є недостатньо досконалими і здебільшого інертними щодо змін у системі державного управління сферою правової охорони інтелектуальної власності. Необхідні зміни, які відповідатимуть сучасним економічним та політичним умовам. 
Метою цієї статті $\epsilon$ дослідження питань сучасного стану системи безпеки інтелектуальної власності, визначення загроз інтелектуальній безпеці та формування напрямів їхнього подолання.

Виклад основного матеріалу. Інтелектуальна безпека підприємства - це достатньо складна та багатофакторна категорія, яка займає належне місце в системі економічної безпеки. До елементів інтелектуальної безпеки підприємства належать: інтелектуальний капітал, інтелектуальний потенціал та інтелектуальна власність.

Механізм інтелектуальної безпеки підприємства повинен гарантувати захист наукового потенціалу не тільки суб'єкта господарської діяльності, а й особистості. Людина, іï свободи та права є найважливішою цінністю еволюційного розвитку суспільства, що сприяє зростанню інтелектуального потенціалу населення кожної країни. Тільки людині притаманні інтелект, творчий потенціал та творчі здібності. Творча діяльність - найважливіший аспект життя людини, що дозволяє продемонструвати свій талант суспільству. Наслідком такої діяльності $\epsilon$ щось нове, неповторне, унікальне та оригінальне. Накопичені продукти діяльності людського розуму становлять спадок нації, обумовлюють її подальший розвиток.

Творчість - це цілеспрямований процес, який характеризується новизною та неповторністю. Матеріальні цінності - це водночас результат творчої праці, продукт діяльності людського розуму.

Конституція України гарантує громадянам держави свободу наукової, художньої, літературної та технічної творчості, захист права інтелектуальної власності, моральних і матеріальних інтересів, що виникають у зв'язку з різними видами інтелектуальної діяльності. Кожний громадянин має право на результати своєї інтелектуальної, творчої діяльності; ніхто не може використовувати або поширювати їх без його згоди, за винятками, встановленими законом (статті 41, 54 Конституції України) [7]. Інтелектуальний потенціал нації, особливо вдосконалення систем освіти, виробництва, культури, науки та техніки, потребує постійної підтримки з боку держави.

Об’ єктом інтелектуальної власності конкретної особистості є результат творчої діяльності, якому надається правова охорона. Але, на жаль, на сьогодні проблему в діяльності підприємств України становить забезпечення належної системи безпеки інтелектуальної власності. Керівники підприємств уважають, що варто більше зважати на фінансову складову економічної безпеки підприємства. Інтелектуальні, творчі та наукові здобутки, на їхню думку, не пов'язані з доходами підприємства. Навпаки, інколи наукові розробки потребують значних капіталовкладень, тоді як вигода від очікуваного результату не завжди чітко прораховується [8].

Необхідно звернути увагу на різне тлумачення науковцями поняття «інтелектуальна безпека»: як забезпечення захисту інтелектуальної власності або як ефективного використання інтелектуального продукту [9; 10]. Деякі дослідники переконані, що інтелектуальна безпека включає всі аспекти: від захисту інтелектуальної власності до формування та зростання інтелектуального капіталу підприємства. Капіталізація інтелектуального капіталу забезпечить підприємству високий рівень конкурентоспроможності та надасть можливість конкретизувати його подальший стратегічний розвиток. Крім того, інтелектуальний складник економічної безпеки підприємства гарантує технологічне вдосконалення виробництва.

Фахівці в галузі економічної безпеки розрізняють інтелектуальну безпеку за підсистемами, які тією чи іншою мірою впливають на конкурентоспроможність підприємства:

- безпека інтелектуальних трудових ресурсів;

- безпека нематеріальних активів;

- безпека інтелектуального капіталу;

- безпека руху знань в організації;

- кібербезпека.

Н. Серебрякова визначила безпеку інтелектуальних трудових ресурсів як носіїв знань. Згідно 3 матеріалами досліджень існує такий стан захищеності трудових ресурсів, який забезпечує ефективну реалізацію індивідуальних і колективних знань у процесі діяльності 
суб'єктів господарювання та запобігає втраті цих знань. Аналітичне дослідження стосувалося питання «розвитку інтелектуальної праці з метою забезпечення безпеки економіки» та «розвитку інтелектуального потенціалу, який включає захищену соціально-економічну інформацію, розроблену людиною або групою осіб, традиційні та інноваційні методи розвитку інтелектуальної праці, які впливають на забезпечення безпеки економіки» [11].

Підсистема «безпека нематеріальних активів» пов'язана 3 носіями організаційних знань. Нематеріальні активи є об'єктами права інтелектуальної власності підприємства i належать до носіїв організаційних знань. До того ж такими носіями є власно створена інтелектуальна база знань та права (майнові, немайнові). Існує низка зовнішніх і внутрішніх загроз, що можуть призвести до втрати підприємством організаційних знань (плагіат, виробничий шпіонаж та інше).

Слід зауважити, що інтелектуальний капітал потребує захисту. Якщо вважати, що формування та зростання інтелектуального капіталу відбувається завдяки інформаційному науковому поповненню, то можна стверджувати про інвестиції в інтелектуальний капітал. Підсистема «безпека інтелектуального капіталу» розглядається як різновид інвестиційної безпеки підприємства. Працівники підприємства інвестують свої знання для його подальшого ефективного розвитку. Таким знанням притаманно невпинно рухатися (створення оволодіння - розповсюдження - обмін - удосконалення - використання - перетворення зберігання). Підсистема «безпека руху знань в організації» має ще одну назву - «безпека організаційного власного капіталу».

Також варто звернути увагу на захищеність інформації, що є частиною визначення «інтелектуальний капітал підприємства». О. Янковий розглядає кібербезпеку як захищеність інформаційно-комунікаційних технологій (конфіденційність, доступність даних і систем) і на цій підставі виокремлює «правопорушення проти конфіденційності, цілісності та доступності комп'ютерних даних і систем; правопорушення, пов'язані з комп'ютерами; правопорушення, пов'язані зі змістом; правопорушення, пов'язані з порушенням авторських та суміжних прав» [12].

Систему безпеки інтелектуальної власності підприємства доцільно розглядати, враховуючи правові аспекти. Статтею 418 Цивільного кодексу України (далі - ЦК України) вперше в національному законодавстві було надано офіційне тлумачення права інтелектуальної власності як права особистості на результат інтелектуальної, творчої діяльності або інший об'єкт права інтелектуальної власності, визначений ЦК України та іншими законами України [13]. Варто зазначити, що право власності та право інтелектуальної власності не впливають та не залежать одне від одного. У статті 419 ЦК України наголошено, що право інтелектуальної власності та право власності на річ існують як самостійні правові категорії [13]. 3 огляду на правові норми інтелектуальна власність $є$ результатом творчої діяльності, яка відповідає вимогам чинного законодавства. Тільки в такому разі їй надається правова охорона.

Доцільно також охарактеризувати поняття «принципи інтелектуальної власності». Ці принципи тісно пов'язані з захистом суб'єктивних прав суб'єктів права інтелектуальної власності; до їх формування мають висуватися певні вимоги. Принцип - це вираження необхідності закону [14]. Принципи інтелектуальної власності засновані на об'єктивних законах розвитку суспільства та на спеціальних законах, що регулюють відносини у сфері інтелектуальної власності. Відповідно до Концепції розвитку національної системи правової охорони інтелектуальної власності основними принципами реалізації Концепції $є$ :

узгодження національного законодавства 3 нормами міжнародних договорів у сфері права інтелектуальної власності;

- $\quad$ нормативно-правове забезпечення прав інтелектуальної власності з урахуванням досвіду національної правової системи;

- $\quad$ формування єдиної політики щодо недопущення порушення прав на об'єкти інтелектуальної власності;

- $\quad$ удосконалення національної системи права інтелектуальної власності; 
- стимулювання інноваційної діяльності та стимулювання громадян, що займаються науковою і творчою діяльністю;

- $\quad$ співробітництво з міжнародними організаціями у сфері інтелектуального права [14].

Існування правових норм, об'єднаних спільними принципами, методами, метою, називають системою права, у нашому разі - системою права інтелектуальної власності. Норми права інтелектуальної власності знаходяться в тісному зв'язку з іншими галузями права i здебільшого належать до матеріальних норм.

Також звернемо увагу на загрози, що можуть вплинути на ефективність системи безпеки інтелектуальної власності. Загрози можуть бути зовнішніми та внутрішніми. До зовнішніх загроз безпеки інтелектуальної власності належать:

власності; відсутність належної системи державного регулювання інтелектуальної безпеки

- $\quad$ дестабілізація конкурентних відносин між підприємствами, між підприємствами та державою;

- н недосконалість національного господарства, що, у свою чергу, впливає на забезпечення безпеки кожного суб'єкта господарювання;

- $\quad$ відсутність управлінських механізмів стимулювання інтелектуальної діяльності;

- $\quad$ відтік інтелектуальних ресурсів за межі країни;

- недостатність фінансування науково-технічних розробок;

- $\quad$ заполітизованість економічних процесів;

- $\quad$ економічна та технологічна залежність України від передових країн світу;

- $\quad$ зневажливе ставлення до людей інтелектуальної праці та інші.

Внутрішні загрози більшою мірою пов'язані з людським фактором. На підприємстві зменшується кількість людей, які займаються наукою та творчістю, тому що керівництво підприємства фінансово не підтримує наукові розробки. Для багатьох підприємств «проблема виживання» не стосується питання інтелектуального розвитку та зростання інтелектуального капіталу. Крім того, переважно відсутній належний внутрішній контроль безпеки інтелектуальної власності на підприємстві.

Наявність структури внутрішнього контролю безпеки на підприємстві, на нашу думку, дозволить:

- оцінити важливість інтелектуального розвитку на підприємстві;

- $\quad$ підвищити рівень свідомості управлінців підприємства щодо формування інтелектуального капіталу та вдосконалення системи інтелектуальної безпеки власності;

- $\quad$ виявити недоліки в системі безпеки;

- $\quad$ спланувати роботу науковців підприємства щодо усунення проблем наукового характеру;

- оцінити дотримання всіх нормативних вимог щодо забезпечення інтелектуальної безпеки власності;

- $\quad$ провести правильний фінансовий розрахунок майбутніх витрат та прибутків від стимулювання інтелектуальної діяльності.

Висновки та перспективи подальших досліджень. Отже, підсумовуючи зазначене вище, можна зробити висновок, що проблемні питання стосовно інтелектуальної власності, безпеки інтелектуальної власності та права на інтелектуальну власність нині є актуальними. Держава не забезпечує належним чином (з позиції права) охорону інтелектуальної власності. На більшості підприємств немає управлінських механізмів стимулювання інтелектуальної діяльності. Тому необхідно сприяти вдосконаленню сфери інтелектуальної власності, що $є$ важливим елементом розвитку нашого суспільства. Питання інтелектуальної безпеки потребує комплексного вирішення як на рівні держави, так і на рівні кожного суб'єкта господарювання. 


\section{Список використаних джерел}

1. Орлик О. В. Економічна безпека підприємства: властивості, стратегія та методи забезпечення : колективна монографія : у 2 т. Дніпропетровськ : ФОП Дробязко С. І., 2014. Т. 2 : Економічна безпека в умовах глобалізації світової економіки. С. 176-182.

2. Ярова Ю. О. Структура економічної безпеки підприємства в умовах кризи. Економічний вісник НТУУ «КПІ». 2016. № 13. URL: http://ev.fmm.kpi.ua (дата звернення: 12.04.2021).

3. Дроб'язко В. С, Дроб'язко Р. В. Право інтелектуальної власності : навч. посібник. К. : Юрінком Інтер, 2004. 512 с.

4. Аксютіна А. В., Нестерцова-Собакарь О. В., Тропін В. В. І Інтелектуальна власність : навч. посібник для студ. вищ. навч. закл. / за заг. ред. О. В. НестерцовоїСобакарь. Дніпро : Дніпроп. держ. ун-т внутр. справ, 2017. 140 с.

5. Орлюк О. П., Андрощук Г. О., Бутнік-Сіверський О. Б. Право інтелектуальної власності: академічний курс : підруч. для студ. вищих навч. закладів / за ред. О. П. Орлюк, О. Д. Святоцького. К. : Видавничий Дім «Ін Юре», 2007. 696 с.

6. Еннан Р. Права на результати інтелектуальної діяльності: зміст та сутність. Теорія і практика інтелектуальної власності. 2011. № 6. С. 10.
7. Конституція
України.

URL: http://zakon4.rada.gov.ua/laws/show/254\%D0\%BA/96-\%D0\%B2\%D1\%80 (дата звернення: 12.04.2021).

8. Ілляшенко О. В. Методологічні засади формування та функціонування механізмів системи економічної безпеки підприємства : дис. ... д-ра екон. наук : 08.00.04; 21.04.02 / Східноукраїнський національний університет імені Володимира Даля. Сєвєродонецьк, 2016. 606 с.

9. Shirley Ann Jackson. Intellectual Security and the Quiet Crisis. Jan. 2017. URL: http://www.rpi.edu/president (дата звернення: 12.04.2021).

10. Мокій А. I., Дацко О. І., Шехлович А. М. Загрози інтелектуальній безпеці держави в умовах посилення еміграційних процесів. Соціально-економічні проблеми сучасного періоду Украӥни. 2013. Вип. 3. С. 283-301.

11. Serebryakova N. A., Ovchinnikova T. I., Bulgakova I. N., Sviridova S. V., Tolstykh T. O. Innovational methods of development of intellectual labor for economy's security. European Research Studies Journal. 2017. № 20 (3). P. 556-569.

12. Янковий О. Г. Конкурентоспроможність підприємства: оцінка рівня та напрями підвищення : монографія / за заг. ред. О. Г. Янкового. Одеса : Атлант, 2013. 470 с.

13. Цивільний кодекс України. Суми : ТОВ «ВВП НОТІС», 2018. 372 с.

14. Про схвалення Концепції реформування державної системи правової охорони інтелектуальної власності в Україні : розпорядження Кабінету Міністрів України від 01.06.2016 p. № 402-p. Офіційний вісник Украӥни. 2016. № 44. С. 48.

\section{References}

1. Orlyk, O. V. (2014). Ekonomichna bezpeka pidpryiemstva: vlastyvosti, stratehiia ta metody zabezpechennia : kolektyvna monohrafiia : u 2 t. [Economic security of the enterprise: Properties, strategy and methods of providing: collective monograph : 2 volumes]. Dnipropetrovsk : FOP Drobiazko S. I. T. 2: Ekonomichna bezpeka v umovakh hlobalizatsii svitovoi ekonomiky. S. 176-182 [in Ukrainian].

2. Yarova, Yu. O. (2016). Struktura ekonomichnoi bezpeky pidpryiemstva v umovakh kryzy. Ekonomichnyi visnyk NTUU «KPI» [The structure of the enterprise's economic security in a crisis. Economic Bulletin of NTUU «KPI»]. № 13. URL: http://ev.fmm.kpi.ua (data zvernennia: 12.04.2021) [in Ukrainian]. 
3. Drobiazko, V. S, Drobiazko, R. V. (2004). Pravo intelektualnoi vlasnosti : navch. posibnyk [The right of intellectual property : a manual]. K. : Yurinkom Inter. 512 s. [in Ukrainian].

4. Aksiutina, A. V., Nestertsova-Sobakar, O. V., Tropin, V. V. (2017). Intelektualna vlasnist : navch. posibnyk dlia stud. vyshch. navch. zakl. [Intellectual Property : tutorial for students of higher educational establishments] / za zah. red. O. V. Nestertsovoi-Sobakar. Dnipro : Dniprop. derzh. un-t vnutr. sprav. 140 s. [in Ukrainian].

5. Orliuk, O. P., Androshchuk H. O., Butnik-Siverskyi O. B. (2007). Pravo intelektualnoi vlasnosti: akademichnyi kurs : pidruch. dlia stud. vyshchykh navch. zakladiv [Intellectual property right: academic course : textbook for students of higher educational establishments] / za red. O. P. Orliuk, O. D. Sviatotskoho. K. : Vydavnychyi Dim «In Yure». 696 s. [in Ukrainian].

6. Ennan R. (2011). Prava na rezultaty intelektualnoi diialnosti: zmist ta sutnist. Teoriia i praktyka intelektualnoi vlasnosti [Rights to the results of intellectual activity: content and essence. The theory and practice of intellectual property]. № 6. S. 10 [in Ukrainian].

7. Konstytutsiia Ukrainy [Constitution of Ukraine]. URL: http://zakon4.rada.gov.ua/laws/show/254\%D0\%BA/96-\%D0\%B2\%D1\%80 (data zvernennia: 12.04.2021) [in Ukrainian].

8. Illiashenko, O. V. (2016). Metodolohichni zasady formuvannia ta funktsionuvannia mekhanizmiv systemy ekonomichnoi bezpeky pidpryiemstva [Methodological principles of formation and functioning of the mechanisms of the system of economic security of the enterprise] : dys. ... d-ra ekon. nauk : 08.00.04; 21.04.02 Skhidnoukrainskyi natsionalnyi universytet imeni Volodymyra Dalia. Sievierodonetsk. 606 s. [in Ukrainian].

9. Shirley Ann Jackson. Intellectual Security and the Quiet Crisis. Jan. 2017. URL: http://www.rpi.edu/president (data zvernennia: 12.04.2021).

10. Mokii, A. I., Datsko, O. I., Shekhlovych, A. M. (2013). Zahrozy intelektualnii bezpetsi derzhavy v umovakh posylennia emihratsiinykh protsesiv. Sotsialno-ekonomichni problemy suchasnoho periodu Ukrainy [Threats to intellectual security of the state in the conditions of strengthening of emigration processes. Socio-economic problems of the modern period of Ukraine]. Vyp. 3. S. 283-301 [in Ukrainian].

11. Serebryakova N. A., Ovchinnikova T. I., Bulgakova I. N., Sviridova S. V., Tolstykh T. O. Innovational methods of development of intellectual labor for economy's security. European Research Studies Journal. 2017. № 20 (3). P. 556-569.

12. Yankovyi, O. H. (2013). Konkurentospromozhnist pidpryiemstva: otsinka rivnia ta napriamy pidvyshchennia : monohrafiia [Competitiveness of the enterprise: Evaluation of the level and direction of increase : monograph] / za zah. red. O. H. Yankovoho. Odesa: Atlant. $470 \mathrm{~s}$. [in Ukrainian].

13. Tsyvilnyi kodeks Ukrainy [The Civil Code of Ukraine]. Sumy : TOV «VVP NOTIS», 2018. 372 s. [in Ukrainian].

14. Pro skhvalennia Kontseptsii reformuvannia derzhavnoi systemy pravovoi okhorony intelektualnoi vlasnosti v Ukraini : rozporiadzhennia Kabinetu Ministriv Ukrainy vid 01.06.2016 r. № 402-r. Ofitsiinyi visnyk Ukrainy [On approval of the concept of reforming the state system of legal protection of intellectual property in Ukraine : the order of the Cabinet of Ministers of Ukraine dated 01.06.2016 № 402-r. Official Bulletin of Ukraine]. 2016. № 44. S. 48 [in Ukrainian].

\author{
Shekhovtsova Victoria, \\ $\mathrm{PhD}$ in Economics \\ (Donetsk State University of Internal Affairs, Kryvyi Rih) \\ ORCID: https://orcid.org/0000-0002-2207-9317
}




\section{THE MODERN VISION OF THE SYSTEM OF INTELLECTUAL PROPERTY RIGHTS IN UKRAINE}

The article is devoted to the research of the intellectual property rights system in Ukraine. Intellectual property is the result of the creative activity of any person or group of people. The author studied the categories «intellectual property» and «intellectual property right», investigated the principles of intellectual property and the system of intellectual property rights of Ukraine. In Roman law, there was the term "property», because the "property right» in its classical meaning was formed in Rome, and related to private relationships. Intellectual property is the property of a person that arose as a result of her creativity. However, for our Ukrainian legislation, the expression «intellectual property» is «terra incognita». Yes, intellectual property is studied by such branch legal sciences as: civil law, administrative law, international law, and others. Formed the State Service of Intellectual Property, but the organization of the state system of legal protection of intellectual property, in our difficult times, wants a better one. In the legal literature on intellectual property issues various definitions of «intellectual property right» are given. From a subjective point of view - this is a subjective right, and from an objective point of view - a civil law institute, a set of legal norms that regulate relations in the system of creation and protection of intellectual property. Man, his freedom and rights are the most important value of evolutionary development of society, which manifests itself in the growth of the intellectual potential of the population of each country. Only man possesses intelligence, creative potential and creative abilities. In addition to it, on earth, no living creature can create. Creative activity is the most important aspect of human life, which allows you to convey your talent to society. The consequence of this activity is something new, unique, unique and original. The accumulated products of the human mind are the heritage of the nation, which determine its further development.The Constitution of Ukraine guarantees to the citizens of the state freedom of scientific, artistic, literary and technical creativity, protection of intellectual property rights, moral and material interests arising in connection with various types of intellectual activity. Every citizen has the right to the results of his intellectual, creative activity; no one can use or distribute them without his consent, with the exception of the statutory provisions. The intellectual potential of the nation, in the form of improving education, production, culture, science and technology, needs constant support from our state. The Civil Code of Ukraine for the first time in our national legislation was given a formal definition of the right of intellectual property, as the rights of the individual to the result of intellectual, creative activity or other object of intellectual property rights.

Key words: intellectual law; intellectual property; creative potential; creative abilities.

Надіслано до редколегії 17.05.2021 Рекомендовано до публікації 21.05.2021 


\title{
РОЗДІЛ ІІІ \\ КРИМІНАЛЬНЕ ПРАВО. КРИМІНОЛОГІЯ
}

\section{УДК: $343.3 / .7$}

DOI: https://doi.org/10.32366/2523-4269-2021-75-2-60-66

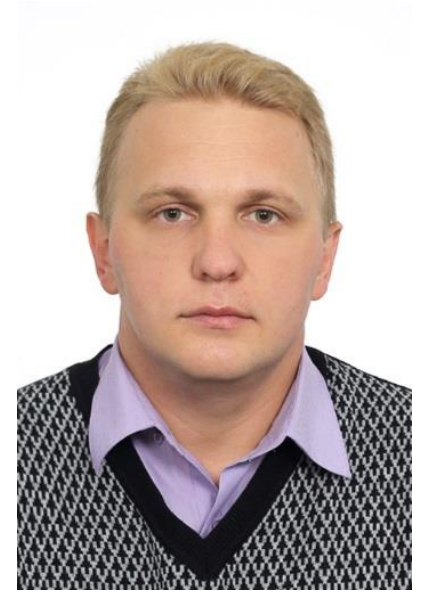

\author{
Данилевський Андрій Олександрович, \\ кандидат юридичних наук, доцент \\ (Донецьький державний університет \\ внутрішніх справ, м. Маріуполь) \\ ORCID: https://orcid.org/0000-0002-9315-9381
}

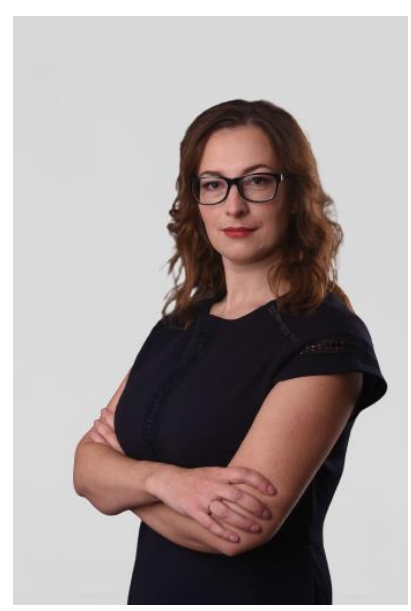

\section{Данилевська Юлія Олександрівна,} кандидат юридичних наук, старший науковий співробітник (Донецький державний університет внутрішніх справ, м. Маріуполь)

ORCID: https://orcid.org/0000-0002-1893-8473

\section{КРИМІНАЛЬНО-ПРАВОВА ОХОРОНА ЗЕМЕЛЬ, НА ЯКИХ ЗНАХОДЯТЬСЯ ОБ'СКТИ НЕРУХОМОЇ КУЛЬТУРНОЇ СПАДЩИНИ: АНАЛІЗ ОКРЕМИХ ЗАКОНОДАВЧИХ ІНІЦАТИВ}

У статті розглядаються проблеми кримінально-правової охорони земель історико-культурного призначення. 3 огляду на свою актуальність аналізуються окремі законодавчі інічіативи щуодо вдосконалення врегулювання питань, пов'язаних із кримінальноправовою охороною земель, на яких розташовані об'єкти нерухомої культурної спадщини. Зокрема, звертається увага на пропозиції щзодо доповнення та змін до ст. 197-1 Кримінального кодексу України. $У$ результаті дослідження норм регулюючого законодавства, положень Кримінального та Земельного кодексів України вказується на недосконалість окремих законопроєктів у uій сфрері.

Ключові слова: культурна спадщина; землі історико-культурного призначення; самовільне будівництво. 
Постановка проблеми. У ст. 54 Конституції України закріплено положення, згідно 3 яким культурна спадщина охороняється законом, а держава забезпечує збереження історичних пам'яток та інших об'єктів, що становлять культурну цінність. Як продовження цих конституційних приписів ухвалено Закон України від 8 червня 2000 року № 1805 «Про охорону культурної спадщини» (далі - Закон), відповідно до якого охорона культурної спадщини - це система правових, організаційних, фінансових, матеріально-технічних, містобудівних, інформаційних та інших заходів з обліку (виявлення, наукове вивчення, класифікація, державна реєстрація), запобігання руйнуванню або заподіянню шкоди, забезпечення захисту, збереження, утримання, відповідного використання, консервації, реставрації, ремонту, реабілітації, пристосування та музеєфікації об'єктів культурної спадщини. Система правових заходів закріплена в нормах охоронних галузей права адміністративного та кримінального, зокрема, Кодекс України про адміністративні правопорушення (далі- КУпАП) містить ст. 92 «Порушення вимог законодавства про охорону культурної спадщини» та ст. 188-33 «Невиконання законних вимог посадових осіб органів охорони культурної спадщини», а Кримінальний кодекс України (далі - КК України) у ст. 298 встановлює відповідальність за незаконне проведення пошукових робіт на об'єкті археологічної спадщини, знищення, руйнування або пошкодження об'єктів культурної спадщини.

Незважаючи на законодавче унормування охорони культурної спадщини, дослідники виділяють низку проблемних аспектів, які потребують негайного реагування з боку держави, серед яких: недосконалість системи управління охороною культурної спадщини; недоліки правових механізмів охорони культурної спадщини; проблеми узгодження потреб охорони культурної спадщини і будівельної діяльності [1]. Саме незаконні забудови земель, на яких розташовані об'єкти культурної спадщини, викликають найбільше занепокоєння у фахівців. Ідеться про землі історико-культурного призначення, що наразі займають більше 40 тис. га, на яких розміщені 140 тис. пам'яток культурної спадщини, що перебувають на державному обліку [2]. Зазначена категорія земель має особливий правовий режим: установлений нормами земельного права порядок регулювання відносин у сфері охорони та обмеженого використання земель історико-культурного призначення спрямований на збереження об'єктів культурної спадщини, які на них розташовані [3, с. 303].

Аналіз останніх досліджень і публікацій. Питання кримінально-правової охорони об'єктів культурної спадщини були предметом наукових розробок таких дослідників, як В. В. Базелюк, Т. Б. Герелюк, Н. В. Кулакова, М. О. Міщенко, В. М. Тертишник та інші. Проте кримінально-правовій охороні земель історико-культурного призначення увага вчених приділялася лише фрагментарно під час розгляду складів злочинів, передбачених ст. 197-1 КК України.

Актуальність дослідження саме цього питання підтверджується й експертами. На думку фахівців, важливою проблемою в галузі збереження культурної спадщини є узгодження інтересів, що стосуються ії охорони, та інтересів, пов'язаних із розвитком населених пунктів та економічною діяльністю, зокрема будівництвом і землекористуванням. Однак на практиці потребами збереження культурної спадщини часто нехтують на користь забудовників та інших суб’єктів економічної діяльності, відбувається це не лише шляхом порушення або маніпулювання чинним законодавством, а й завдяки його змінам, спрямованих на створення обмежень для пам'яткоохоронної та дослідницької діяльності [1].

На противагу цьому розроблена низка законопроєктів, якими посилюється відповідальність за руйнування та знищення нерухомої культурної спадщини й порушення традиційного характеру середовища. Підтримуючи такий крок законодавця, зупинимо увагу на одній 3 останніх законодавчих ініціатив. Зокрема, законопроєкт, зареєстрований Верховною Радою України IX скликання, присвячений цій тематиці, за реєстраційним № 4562 пропонує низку змін до КУпАП та КК України.

Формування цілей статті (постановка завдання). Метою цієї статті $\epsilon$ аналіз законодавчих ініціатив, закріплених у законопроєкті № 4562 «Про внесення змін до деяких 
законодавчих актів України щодо посилення відповідальності за руйнування та знищення нерухомої культурної спадщини і порушення традиційного характеру середовища», та співвідношення положень цього законопроєкту (далі - Проєкт) з положеннями КК України, Земельного кодексу України, Закону України від 8 червня 2000 року № 1805 «Про охорону культурної спадщини».

Виклад основного матеріалу. Проєктом передбачається змінити та доповнити ст. 197 1 КК України «Самовільне зайняття земельної ділянки та самовільне будівництво». По-перше, пропонується узгодити положення кримінального законодавства 3 нормами ЦК України (ст. 376) стосовно заміни словосполучення «самовільне будівництво» на «самочинне будівництво», що є логічним та необхідним.

По-друге, Проєктом пропонується доповнити ст. 197-1 КК України трьома новими частинами щодо самочинного будівництва будівель або споруд: в історичному ареалі історичних населених місць (ч. 5 ст. 197-1), на території історико-культурного заповідника, історико-культурної заповідної території, об'єкта всесвітньої спадщини або в його буферній зоні (ч. 6 ст. 197-1), дії, передбачені частиною п’ятою та шостою цієї статті, якщо вони вчинені повторно (ч. 7 ст. 197-1).

Для оцінки такої законодавчої ініціативи вбачаємо доцільним дослідити статус перелічених вище територій, що, на думку авторів Проєкту, відрізняється від статусу земель, які наразі зазначені в ст. 197-1 КК України. Так, згідно зі ст. 53 Земельного кодексу України «Склад земель історико-культурного призначення» території історико-культурного заповідника, історико-культурні заповідні території входять до складу земель історикокультурного призначення.

Що ж стосується земель об'єкта всесвітньої спадщини або його буферної зони, то їх, на перший погляд, не можна віднести до земель пам'ятки культурної спадщини, які так само $є$ землями історико-культурного призначення. Згідно зі ст. 1 Закону України «Про охорону культурної спадщини» пам'ятка культурної спадщини - це об'єкт культурної спадщини, який занесено до Державного реєстру нерухомих пам'яток України, а об'єкт всесвітньої спадщини - це об'єкт культурної спадщини, включений до Списку всесвітньої спадщини ЮНЕСКО відповідно до Конвенції про охорону всесвітньої культурної і природної спадщини. Тобто йдеться про два різні види реєстрів (списків). Проте ч. 1 ст. 37-2 Закону проголошує, що об'єкт всесвітньої спадщини має правовий статус пам'ятки національного значення з урахуванням особливостей, установлених Конвенцією, цим Законом і планом управління об'єктом всесвітньої спадщини.

Отже, незважаючи на юридичну казуїстику, фактично об’єкт всесвітньої спадщини можна вважати пам'яткою культурної спадщини.

У свою чергу, землі історико-культурного призначення відповідно до ст. 150 Земельного кодексу України належать до особливо цінних земель.

Кримінально-правова охорона особливо цінних земель наразі передбачена ч. 2 ст. 1971 КК України «Самовільне зайняття земельної ділянки та самовільне будівництво» та ч. 3 цієї ж статті щодо самовільного будівництва будівель або споруд на самовільно зайнятій земельній ділянці, у тому числі особливо цінних земель. Як бачимо, фактично у Проєкті пропонують криміналізувати діяння, за вчинення яких на сьогодні кримінальну відповідальність установлено.

За своїм змістом буферна зона як територія навколо об'єкта всесвітньої спадщини, що забезпечує охорону цілісності та автентичності видатної універсальної цінності цього об'єкта та в межах якої встановлюється відповідний режим використання, є тотожною зоні охорони пам'ятки -встановлюваної навколо пам'ятки охоронної зони, зони регулювання забудови, зони охоронюваного ландшафту, зони охорони археологічного культурного шару, в межах яких діє спеціальний режим їх використання (ст. 1 Закону України від 8 червня 2000 року № 1805 «Про охорону культурної спадщини»).

Так, відповідно до ст. 112 Земельного кодексу України охоронні зони створюються навколо, зокрема, об'єктів культурної спадщини. Водночас зони охорони пам'яток не 
належать до земель історико-культурного призначення. Але самовільне зайняття земель в охоронних зонах або самовільне будівництво на таких землях кваліфікується за ч. 2 або ч. 4 ст. 197 КК України.

Тобто Проєктом пропонується знову криміналізувати діяння, кримінальна відповідальність за вчинення яких уже передбачена ст. 197-1 КК України.

Крім того, термінологія, яка використовується в запропонованій редакції ст. 197-1 КК України, не повною мірою відповідає положенням Закону. Так, запропоноване у Проєкті словосполучення «історичний ареал історичних населених місць» є некоректним з огляду на те, що Закон оперує поняттями «історичне населене місце» та «історичний ареал населеного місця». Запропонований підхід позбавляє кримінально-правового захисту історичного ареалу населених місць, які не належать до історичних.

Відповідно до ст. 1 Закону історичне населене місце - це населене місце, яке зберегло повністю або частково історичний ареал і занесене до Списку історичних населених місць України; а історичний ареал населеного місця - це частина населеного місця, що зберегла об'єкти культурної спадщини і пов'язані з ними розпланування та форму забудови, які походять $з$ попередніх періодів розвитку, типові для певних культур або періодів розвитку. Таким чином, йдеться про земельну ділянку чи землі, на яких знаходяться об'єкти культурної спадщини, а отже й про землі історико-культурного призначення. Таке тлумачення підтверджується і судовою практикою.

Так, постановою Верховного Суду від 31 липня 2019 року у справі № 813/4701/16 (№ K/9901/43183/18) було встановлено, що оскільки земельна ділянка знаходиться в межах історичного ареалу відповідно до Генерального плану м. Львова, а будівля готелю, що розміщується на спірній земельній ділянці у м. Львові, є пам'яткою архітектури місцевого значення, до того ж у 2005 році було затверджено межі історичного ареалу та межі території історичної забудови, внесеної до списку всесвітньої спадщини ЮНЕСКО, то, зважаючи на імперативність правової норми, передбаченої у ч. 1 ст. 34 Закону, земельна ділянка належить до земель історико-культурного призначення за фактом знаходження на ній споруди (будівлі), яка є пам'яткою архітектури [4].

По-третє, у Проєкті пропонуються зміни до ст. 197-1 КК України з використанням понять «будівля», «споруда», «населене місце» у множині, що може призвести до того, що буквальне тлумачення норм кримінального законодавства позбавить можливості притягнути до кримінальної відповідальності особу, яка здійснила самочинне будівництво однієї будівлі чи споруди на землях історико-культурного призначення.

Оскільки й чинна редакція ст. 197-1 КК України оперує поняттями «будівля», «споруда» у множині, убачається правильною думка дослідників про необхідність використання замість формулювання «будівель або споруд» словосполучення «об'єкта нерухомого майна, який підлягає обов'язковій державній реєстрації», що підвищить ефективність кримінально-правової протидії суспільно небезпечним проявам, згаданим у ст. 197-1 КК України [5].

По-четверте, спірним уважаємо підхід до визначення розміру та видів покарань. Так, санкції частин 5-7 ст. 197-1 КК України в запропонованій Проєктом редакції містять лише два альтернативних види покарань: штраф та позбавлення волі. Ураховуючи той факт, що зазначені склади кримінальних правопорушень відносяться до нетяжких злочинів, подібний підхід видається дивним. Злочини невеликої тяжкості повинні мати більший арсенал альтернативних покарань для належної індивідуалізації покарання.

Викликають зауваження і розміри штрафів. Так, санкції зазначених частин містять вказівку на покарання у вигляді штрафу в розмірі від 100 тисяч до 500 тисяч неоподатковуваних мінімумів доходів громадян. 3 огляду на те, що йдеться про кримінальні правопорушення невеликої тяжкості, такий розмір покарання вбачаємо надмірним та таким, що не відповідає тяжкості діяння. Також слід ураховувати той факт, що суб'єктом цього злочину є фізична особа, у приватній власності якої навряд чи буде сума, достатня для виплати 
такого штрафу, тому цілком вірогідно, що основним видом покарання за це кримінальне правопорушення стане позбавлення волі.

Зважаючи на невеликий термін позбавлення волі, більшість суб'єктів цього кримінального правопорушення будуть прагнути приховати свій дійсний майновий стан, щоб їм призначили покарання у вигляді позбавлення волі, яке вони, найімовірніше, не будуть відбувати, адже переважно в таких ситуаціях покарання призначається з випробуванням.

По-п’яте, запропоновані Проєктом зміни до різних нормативно-правових актів характеризуються суперечливістю. Так, пропонується доповнити п. 3 ч. 1 ст. 96-3 КК України словосполученням «у частинах п’ятій-сьомій статті 197-1». Цей пункт передбачає таку підставу застосування заходів кримінально-правового характеру до юридичних осіб, як вчинення iї уповноваженою особою від імені юридичної особи певного кримінального правопорушення.

Водночас пропонується викласти ст. 43 Закону в редакції з вказівкою на можливість застосування заходів кримінально-правового характеру в разі вчинення від імені та в інтересах юридичної особи ії̈ уповноваженою особою злочину самостійно або у співучасті до юридичної особи. Така невідповідність може спричинити неоднозначне застосування норм кримінального законодавства.

Узагалі доповнення подібними нормами регулюючого законодавства вважаємо недоцільним, оскільки підставою для застосування будь-яких заходів кримінально-правового впливу є норми саме кримінального законодавства, вказівка на можливість їх застосування у Законі не має жодних юридичних наслідків.

Крім цього, запропонована у Проєкті редакція ст. 43 Закону щодо словосполучення «самостійно або у співучасті до юридичної особи» не тільки встановлює зайву ознаку, адже кримінальний закон не диференціює застосування заходів кримінально-правового характеру до юридичних осіб залежно від того, чи одноособово або у співучасті вчинене кримінальне правопорушення, але i $\epsilon$ некоректною, тому що припускає можливість учинення кримінального правопорушення уповноваженою особою в співучасті з юридичною особою, хоча положення статей 18 та 26 КК України чітко й однозначно встановлюють, що співучасть можлива тільки серед фізичних осіб.

Висновки та перспективи подальших розвідок. Проведений аналіз свідчить, що кримінально-правові норми, описані у ст. 197-1 КК України, здатні реалізувати охоронну функцію щодо незаконного зайняття чи самочинного будівництва на землях історикокультурного призначення, а тому необхідності у прийнятті недосконалого з точки зору юридичної техніки законопроєкту № 4562 «Про внесення змін до деяких законодавчих актів України щодо посилення відповідальності за руйнування та знищення нерухомої культурної спадщини і порушення традиційного характеру середовища» немає.

Перспективним напрямом наукових пошуків і можливих законодавчих ініціатив iз досліджуваного питання може бути розробка заходів кримінально-правового впливу щодо осіб, які незаконно забудовують землі, на яких розташовані об'єкти культурної спадщини.

\section{Список використаних джерел}

1. Інституційні та правові проблеми збереження культурної спадщини / Національний інститут стратегічних досліджень. URL: https://niss.gov.ua/doslidzhennya/gumanitarniy-rozvitok/instituciyni-ta-pravovi-problemizberezhennya-kulturnoi (дата звернення: 02.03.2021).

2. Як землеустрій пов'язаний із охороною культурної спадщини? / Національний університет біоресурсів і природокористування України. URL: https://nubip.edu.ua/node/84337 (дата звернення: 02.03.2021).

3. Гулкевич О. Правовий режим земель історико-культурного призначення. Юридичний вісник. 2020. № 2. С. 297-305. 
4. Постанова Верховного Суду від 31 липня 2019 року у справі № 813/4701/16 (№ K/9901/43183/18). URL: https://reyestr.court.gov.ua/Review/83379362 (дата звернення: 02.03.2021).

5. Мовчан Р. О. Кримінальна відповідальність за злочини у сфері земельних відносин: законодавство, доктрина, практика : монографія. Вінниця : «ТВОРИ», 2020. 1152 с.

\title{
References
}

1. Instytutsiini ta pravovi problemy zberezhennia kulturnoi spadshchyny [Institutional and Legal Problems of Preservation of Cultural Heritage] / Natsionalnyi instytut stratehichnykh doslidzhen. URL: https://niss.gov.ua/doslidzhennya/gumanitarniy-rozvitok/instituciyni-ta-pravoviproblemi-zberezhennya-kulturnoi (data zvernennia: 02.03.2021) [in Ukrainian].

2. Yak zemleustrii poviazanyi iz okhoronoiu kulturnoi spadshchyny? [How is land management associated with the protection of cultural heritage?] / Natsionalnyi universytet bioresursiv i pryrodokorystuvannia Ukrainy. URL: https://nubip.edu.ua/node/84337 (data zvernennia: 02.03.2021) [in Ukrainian].

3. Hulkevych, O. (2020). Pravovyi rezhym zemel istoryko-kulturnoho pryznachennia [Legal regime of land of historical and cultural purpose]. Yurydychnyi visnyk. № 2. S. 297-305 [in Ukrainian].

4. Postanova Verkhovnoho Sudu vid 31 lypnia 2019 roku u spravi № 813/4701/16 (№ K/9901/43183/18) [Resolution of the Supreme Court of July 31, 2019 in the case № 813/4701/16 (№ K/9901/43183/18)]. URL: https://reyestr.court.gov.ua/Review/83379362 (data zvernennia: 02.03.2021) [in Ukrainian].

5. Movchan, R. O. (2020) Kryminalna vidpovidalnist za zlochyny u sferi zemelnykh vidnosyn: zakonodavstvo, doktryna, praktyka [Criminal liability for crimes in the field of land relations: legislation, doctrine, practice] : monohrafiia. Vinnytsia : «TVORY». $1152 \mathrm{~s}$. [in Ukrainian].

\author{
Danylevskyi Andriy, \\ $\mathrm{PhD}$ in Law, Associate Professor \\ (Donetsk State University of Internal Affairs, Mariupol) \\ ORCID: https://orcid.org/0000-0002-9315-9381
}

Danylevska Yuliya,

$\mathrm{PhD}$ in Law, Senior Researcher

(Donetsk State University of Internal Affairs, Mariupol)

ORCID: https://orcid.org/0000-0002-1893-8473

\section{CRIMINAL LEGAL PROTECTION OF LANDS ON WHICH THE OBJECTS OF IMMOVABLE CULTURAL HERITAGE ARE LOCATED: ANALYSIS OF CERTAIN LEGISLATIVE INITIATIVES}

In connection with the numerous facts of violations of the special legal regime of historical and cultural lands, in particular, their illegal development, a number of draft laws have been developed, which increase the responsibility for the destruction of immovable cultural heritage and violation of the traditional nature of the environment. The presented work is devoted to the analysis of legislative initiatives enshrined in the draft law No. 4562 "On Amendments to Certain Legislative Acts of Ukraine Concerning Strengthening Responsibility for the Destruction of Immovable Cultural Heritage and Violation of the Traditional Nature of the Environment», and the correlation of the provisions of this draft law with the provisions of the Criminal Code of Ukraine, the Land Code of Ukraine, the Law of Ukraine "On the Protection of Cultural Heritage». Thus, the draft law is proposed to supplement Art. 197-1 of the Criminal Code of Ukraine «Unauthorized occupation of a 
land plot and unauthorized construction» with three new parts regarding the unauthorized construction of buildings or structures: in the historical area of historical settlements (Part 5 of Art. 197-1); on the territory of a historical and cultural reserve, a historical and cultural protected area, a world heritage site or in its buffer zone (Part 6 of Art. 197-1); and the acts provided for by parts five and six of this article, if they are committed repeatedly (Part 7 of Art. 197-1). In addition, it is proposed to determine the type and amount of punishment for these acts. The conducted research shows that the criminal law norms described in Art. 197-1 of the Criminal Code of Ukraine, are able to implement a protective function regarding illegal occupation or unauthorized construction on lands of historical and cultural purposes, and therefore there is no need to adopt the law draft No. 4562 «On Amendments to Certain Legislative Acts of Ukraine Concerning Strengthening Responsibility for the destruction of immovable cultural heritage and violation of the traditional character of the environment», which is imperfect in terms of legal drafting methodology. However, a promising direction of scientific research and possible legislative initiatives on the issue under consideration may be the development of measures of criminal legal action against persons who illegally build up the lands on which cultural heritage sites are located.

Key words: cultural heritage; lands of historical and cultural purposes; unauthorized construction.

Надіслано до редколегії 11.03.2021

Рекомендовано до публікації 19.03.2021 
DOI: https://doi.org/10.32366/2523-4269-2021-75-2-67-73

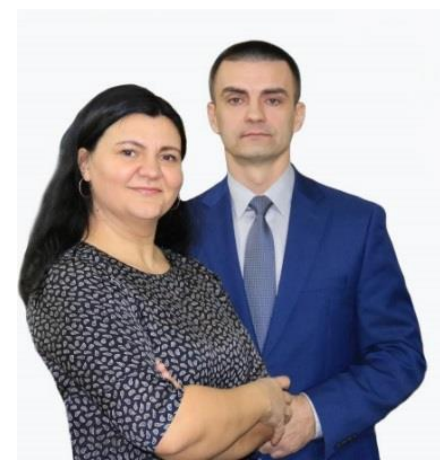

\section{Коміссаров Микола Леонідович,} кандидат юридичних наук, доцент (Донеиький державний університет внутрішніх справ, м. Кривий Ріг) ORCID: https://orcid.org/0000-0001-6828-7974

Коміссарова Наталя Олександрівна, кандидат юридичних наук, доцент (Донеиький державний університет внутрішніх справ, м. Кривий Ріг) ORCID: https://orcid.org/0000-0001-6895-6891

\section{ТЕРМІНОЛОГІЯ КРИМІНАЛЬНОГО ПРАВА}

У статті розглядаються питання доцільності використання у прочесі нормотворення семантично точних та зрозумілих термінів, щзо максимально правильно позначають діï, предмети чи осіб з огляду на протиправні дії або склад злочину, які описані у відповідній статті Кримінального кодексу Украӥни. На прикладі декількох статей чинного Кримінального кодексу Украӥни пропонуються підходи щзодо вдосконалення нормативно-правових актів шляхом використання вдалих термінів: юридичних $i$ загального вжитку. Аналізуються критерії, що могли б стати основою для формування та покращення законодавства взагалі та кримінального законодавства зокрема.

Ключові слова:

кримінальне право; термінологія; юридична термінологія; нормотворення; термінознавство; право.

Постановка проблеми. Спочатку було слово. За всіх часів значення слова чи терміна відігравало суттєву роль. Нині, в умовах перенасиченого інформаційного простору, недостовірної інформації та спотвореного контенту, сенс кожного слова, його тлумачення та розуміння набувають ще більшої ваги . Особливо важливо це враховувати в законотворчій діяльності, коли слово чи термін може вирішити подальшу долю людини.

Загальновідомо, що термін - це слово або словосполучення, яке узгоджується з чітко окресленим поняттям певної галузі науки, техніки, мистецтва, суспільно-політичного життя і вступає у системні відношення з іншими подібними одиницями мови, утворюючи разом 3 ними особливу систему - термінологію [1, с. 1444].

Варто зауважити, що лексема «термін» в українській мові має два значення: обмежений проміжок часу та слово чи словосполучення, яке точно позначає певне поняття в науці, техніці, мистецтві. Характерно, що обидві дефініції походять від латинського terminus - прикордонний (межовий) знак [2, с. 554]. Тобто за різного тлумачення сутність явища залишається незмінною - визначити межі. Саме тому важливо використовувати терміни, відповідні за змістом загальному контексту та конкретному завданню.

Мовознавці виділяють такі ознаки терміна:

(C) Коміссаров Микола Леонідович,

Коміссарова Наталя Олександрівна, 2021 
- має чітке визначення, зафіксоване у словнику;

- однозначний у межах певної термінологічної системи або має тенденцію до однозначності;

- точний і не залежить від контексту;

- стилістично нейтральний;

- системний (класифікаційна системність, словотвірна системність);

- відсутність синонімів у межах однієї терміносистеми;

- короткість (стислість) у плані вираження.

Терміни є не ізольованими одиницями загальнонаціональної мови, а частиною іiі словникового складу. Для правильного розуміння основних вимог до терміна впроваджено поняття «поля». Поле для терміна - це те саме, що контекст ${ }^{1}$ для звичайного слова чи

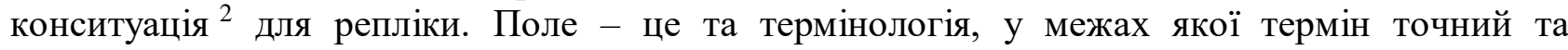
однозначний. Поза межами певного термінологічного поля він втрачає свою характеристику, набуває інших системних зв'язків. Отже, усі основні риси притаманні термінам лише в межах їхнього термінологічного поля. Наше дослідження спрямоване саме на термінологічне поле юриспруденції, зокрема кримінального права.

Аналіз останніх досліджень і публікацій. Аналіз українського кримінального законодавства показує, що інколи певні слова (терміни) використовуються законотворцем без урахування їх змістовного навантаження; або з урахуванням завчасно визначених самим законотворцем дій, які в нормах закону не відображаються, але позначаються невдалим терміном; або вживаються конкретизовані терміни там, де їхнє застосування взагалі не доречне. 3 огляду на це та зважаючи на поширеність юридичної термінології поза професійною сферою, особливо актуально постає питання про точність, зрозумілість, простоту, ясність юридичної мови, зокрема й термінології кримінального права.

Проблеми юридичного термінознавства вивчали В. В. Виноградов, Б. М. Головін, С. В. Гриньов, В. П. Даниленко, А. О. Дудка, Л. О. Симоненко та інші. Ураховуючи наявні напрацювання та успіхи в цьому питанні, варто звернути увагу на непоодинокі випадки невідповідного або недоречного використання термінів чи їх сполучень.

Метою цієї статті $\epsilon$ спроба авторів звернути увагу законотворців та залучених до цієї роботи фахівців на необхідність прискіпливого вибору семантично відповідних термінів під час створення законодавчих актів узагалі та вдосконалення деяких чинних кримінальноправових норм зокрема.

Виклад основного матеріалу. Розглянемо зазначене питання на прикладі декількох статей Кримінального кодексу України (далі - КК України), першою з яких проаналізуємо статтю 14 «Готування до кримінального правопорушення».

Частина перша цієї статті передбачає, що готуванням до кримінального правопорушення $\epsilon$ підшукування або пристосування засобів чи знарядь, підшукування співучасників або змова на вчинення кримінального правопорушення, усунення перешкод, а також інше умисне створення умов для вчинення кримінального правопорушення ${ }^{3}$.

На нашу думку, використаний у цій статті термін «підшукування» $є$ невдалим і не відображає об'єктивної сторони діяння, за яке згідно зі статтею 16 Кримінального кодексу України за певних умов передбачена кримінальна відповідальність.

\footnotetext{
${ }^{1}$ Контекст (семантичний аспект) - імпліцитно (приховано) або експліцитно (відверто) виражені смисли, що реально існують і є частиною ситуації, відображаються в дискурсі та є актуальними для цього комунікативного акту.

${ }^{2}$ Конситуація (екстралінгвальний аспект) - об'єктивно наявна екстралінгвальна (позамовна) ситуація спілкування; умови спілкування і його учасники (хто, що, де, коли).

${ }^{3}$ Кримінальний кодекс України. Відомості Верховної Ради Украӥни. 2001. № 25-26. CT. 131. URL: https://zakon.rada.gov.ua/laws/show/2341-14\#Text (дата звернення: 26.02.2021).
} 
У науково-практичному коментарі до частини 1 статті 14 КК України зазначено, що підшукування засобів чи знарядь для вчинення кримінального правопорушення - це будь-які дії з придбання, отримання, тимчасового позичення, купівлі, пошуку, засобів чи знарядь для вчинення кримінального правопорушення тощо. Підшукування ж співучасників - це будь-які дії з притягнення, залучення до вчинення кримінального правопорушення інших осіб: виконавця (співвиконавця), організатора, підбурювача або пособника [3, с. 38].

Важливо розуміти, що під час підготовки до кримінального правопорушення дії винного ще безпосередньо не спрямовані на охоронюваний кримінальним законом об'єкт і не становлять для нього прямої небезпеки. Суб'єкт ще не виконує того діяння, яке є необхідною ознакою об’єктивної сторони складу кримінального правопорушення. 3 об'єктивної сторони готування до кримінального правопорушення може проявлятися в різних діях, але спільним для них $є$ те, що всі вони полягають лише у створенні умов для вчинення кримінального правопорушення, яке, однак, не завершується 3 причин, що не залежать від волі винного (наприклад, винного затримали органи влади).

Із суб'єктивної сторони готування до кримінального правопорушення можливе тільки 3 прямим умислом, тобто особа усвідомлює, що створює умови для вчинення певного кримінального правопорушення і хоче створити такі умови. При цьому винний має умисел не обмежуватися лише готуванням до кримінального правопорушення, а вчинити такі дії, які призведуть до закінчення кримінального правопорушення.

Згідно з етимологічним словником української мови шукати - означає «намагатися знайти», що і є закінченням відповідної дії [4, с. 486]. Новий тлумачний словник української мови визначає, що термін «шукати» позначає дію щодо виявлення чогось, намагання дізнатися про наявність або місцезнаходження чогось або когось [5, с. 835]. Жодним чином термін «шукати» за своїм змістом не вказує на те, про що йдеться у коментарях до цієї статті, а саме придбання засобів і знарядь будь-яким способом (купівля, обмін, викрадення, отримання в борг тощо).

У певних випадках автори коментарів до Кримінального кодексу України уникають використання зазначеного в частині першій статті 14 терміна «підшукування», розкриваючи зміст діяння щодо створення сприятливих умов для вчинення кримінального правопорушення [6, с. 20].

Використання терміна «підшукування» із вказаним тлумаченням у кримінальному законодавстві дисонує i 3 термінологією кримінального процесуального законодавства. Прикладом може бути стаття 234 «Обшук» Кримінального процесуального кодексу України, у якій термін «обшук» визначається відповідно до свого смислового навантаження, бо в статті зазначено, що обшук проводиться з метою виявлення та фіксації відомостей про обставини вчинення кримінального правопорушення, відшукання знаряддя кримінального правопорушення або майна, яке було здобуте в результаті його вчинення, а також установлення місцезнаходження розшукуваних осіб [7, с. 109]. У контексті нашого дослідження ключовими словами, що розкривають сутність указаної слідчої дії, є виявлення, відшукання, встановлення місця знаходження. Жодним чином не придбання чи викрадення.

Вирішенням зазначеної вище проблеми могла б стати зміна тексту Кримінального кодексу України, робота над яким наразі триває. Проєкт нового Кримінального кодексу, оприлюднений на офіційній сторінці робочої групи з питань розвитку кримінального права Комісії з питань правової реформи, створеної відповідно до Указу Президента України № 584/2019 від 07.08.2019 р., містить статтю 2.4.2 «Готування до злочину», у першій частині якої зазначено: 1. Готування до злочину вчинила особа, яка, діючи 3 прямим умислом, створила умови для вчинення злочину, а саме: а) створила, підшукала або пристосувала засіб чи знаряддя вчинення злочину, б) підшукала співучасника чи досягла змови на вчинення злочину або в) усунула перешкоду для вчинення злочину (курсив наш. $-M . K ., H$. K.) [8].

Очевидно, що авторський колектив указаного проєкту Кримінального кодексу більш ретельно готував нову редакцію відповідної норми (як і всього проєкту), але уникнути використання терміна «підшукування» не вдалося. 
На нашу думку, термін «підшукування» варто вилучити зі статті 14 чинного КК України та статті 2.4.2 проєкту нового Кримінального кодексу, замінивши його термінами «купівля», «обмін», «викрадення», «отримання в борг», якщо йдеться про знаряддя злочину, та застосувавши лексеми «притягнення» i «залучення», якщо мова йде про участь співучасників. Названі терміни точніше передають зміст готування як умисного створення умов для вчинення кримінального правопорушення, при цьому уникаючи словосполучення «придбання... будь-яким способом».

Прикладом вдалого використання термінів «придбання» та «викрадення» є статті 262 та 263 Кримінального кодексу України, у яких придбання не ототожнюється, зокрема, 3 викраденням.

Однак згадана стаття 263 «Незаконне поводження зі зброєю, бойовими припасами або вибуховими речовинами» у другій частині ілюструє інший недолік законотворчості недоречне використання цілком конкретизованих термінів, а саме типів холодної зброї: кинджали, фінські ножі, кастети. Через застосування цих термінів друга частина статті 263 сприймається неоднозначно. Вона має такий зміст: носіння, виготовлення, ремонт або збут кинджалів, фінських ножів, кастетів чи іншої холодної зброї без передбаченого законом дозволу ${ }^{4}$. Відповідно до зазначеної редакції статті, на думку законотворця, будь-який кастет, кинджал чи фінський ніж є холодною зброєю. Проте це не обов'язково відповідає дійсності. Не вдаючись до технічних нюансів, зазначимо, що не всі фінські ножі та не всі кинджали $€$ холодною зброєю. Для уникнення непорозумінь щодо сприйняття і тлумачення частини другої статті 263 варто було б побудувати іï за зразком першої частини цієї ж статті, яка окреслює лише приналежність виробів до певного класу зброї - вогнепальної, хоча і цей термін, на наш погляд, є невдалим.

Терміном «вогнепальна зброя» в чинному законодавстві, у тому числі й кримінальному, позначається зброя, у якій для здійснення пострілу снарядом використовується енергія згорання пороху або речовини, що його замінює. Тому вважаємо, що варто замість цього терміна вжити термін «вогнестрільна зброя» як більш семантично точний - стріляти завдяки вогню. Його правильність підтверджується існуванням термінів «стрілецька зброя», «стріляти», «постріл», «стрілянина». Уживання поняття «вогнепальна зброя» було б більш доречним для зброї іншого класу - вогнеметів, які призначені для підпалу цілі 3 використанням струменя відкритого вогню або капсули із займистою сумішшю, що спалахує після потрапляння в ціль, однак з огляду на принципи роботи такої зброї - метати вогонь, більш точною буде дефініція «вогнеметна зброя». Тому пропонуємо термін «вогнепальна зброя» надалі не застосовувати, замінивши його запропонованими термінами відповідно до класу зброї. I хоча ця позиція висловлена достатньо давно як авторами, так й іншими дослідниками, законотворці наполегливо ігнорують і1і, що свідчить про поверховий підхід до вдосконалення законодавства. Прикладом цього можуть бути законопроєкти щодо обігу цивільної зброї, зареєстровані у Верховній Раді України в 2020 році, у яких автори знову вдаються до використання неточного терміна «вогнепальна зброя» [9].

Продовжуючи обрану тему, не можна залишити поза увагою спроби законотворців упровадити в кримінальне законодавство жаргонну лексику, зокрема таке поняття, як «злодій у законі». Підтримуємо думку О. О. Кваші про те, що буквальне тлумачення таких жаргонізмів нівелює фундаментальне значення слова «Закон» [10, с. 68]. Крім того, автори подібних новел через намагання дати пояснення згаданим «категоріям» ще більше погіршують ситуацію, пропонуючи такі конструкції, як «злочинний вплив», «здійснювати злочинний вплив», «суб'єкт підвищеного злочинного впливу», «встановлення або поширення злочинного впливу», «авторитет», «особисті якості чи можливості», «інший вплив на злочинну діяльність», які мають надто невизначений та оціночний характер [10, с. 70]. Слід погодитися, що такий підхід, зважаючи на незадовільний стан правоохоронної діяльності, призводить до

\footnotetext{
${ }^{4}$ Кримінальний кодекс України. Відомості Верховної Ради України. 2001. № 25-26. Ст. 131. URL: https://zakon.rada.gov.ua/laws/show/2341-14\#Tеxt (дата звернення: 26.02.2021).
} 
свавілля і необмежених суддівських повноважень. Про жодну уніфікацію судових рішень не може йтися.

Натомість є і вдалі приклади запровадження в кримінальне законодавство нових, точних, таких, що розкривають суть питання, термінів. Свідченням цього можуть бути статті КК України: $126^{1}$ «Домашнє насильство», 152 «Згвалтування» та 153 «Сексуальне насильство» (у редакції 2017 року), у яких уживаються терміни «подружжя» та «колишнє подружжя», які раніше в кримінальному законодавстві не використовувалися ${ }^{5}$. Варто зауважити, що поняття «подружжя» в українській мові означає як шлюбну пару, так й окремих iї членів: «дружина щодо свого чоловіка або чоловік щодо своєї дружини» [1, с. 1011]. Саме в останньому значенні термін «подружжя» застосовується у згаданій статті Кримінального кодексу України і його цінність полягає не тільки в тому, що він окреслює соціальний статус потерпілої сторони, а й формує специфічну групу учасників кримінально-правових відносин - «спеціальні потерпілі» та специфічну групу злочинів - «злочини, пов'язані 3 домашнім насильством» [11].

Висновки. Формування норм законів та їх прийняття - ретельний і відповідальний процес, який має бути спрямований на утворення доступного для сприйняття правового поля. Саме зрозумілість правової норми, зокрема кримінально-правової, дасть змогу уникати свавілля і зловживань з боку правозастосовних структур та ефективніше впроваджувати в суспільстві концепцію позитивної кримінально-правової відповідальності. Термін «відповідальність» у своїй етимологічній основі містить слова «знати» й «бачити», що вкотре підкреслює значущість і важливість порушеної нами теми. Звісно, для грунтовного розуміння законів необхідна юридична освіта, але i їхні положення повинні бути максимально зрозумілими для всіх громадян України.

\section{Список використаних джерел}

1. Великий тлумачний словник сучасної української мови (з дод., допов. та $\mathrm{CD}$ ) / уклад. і голов. ред. В. Т. Бусел. К. : Ірпінь : ВТФ «Перун», 2009. 1736 с.

2. Етимологічний словник української мови : у 7 т. / редкол.: О. С. Мельничук (голов. ред.) та ін. К. : Наук. думка, 1983. Т. 5 Р-Т / уклад.: Р. В. Болдирєв та ін. 2006. 704 с.

3. Кримінальний кодекс України : науково-практичний коментар. Видання восьме, перероблене та доповнене / відп. ред. Є. Л. Стрельцов. Х. : Одіссей, 2012. 904 с.

4. Етимологічний словник української мови : у 7 т. / редкол.: О. С. Мельничук (голов. ред.) та ін. К. : Наук. думка, 1983. Т. 6 У-Я / уклад.: Г. П. Півторак та ін. 2012. 568 с.

5. Новий тлумачний словник української мови : у 3 т. / редкол.: О. А. Аматуні (голов. ред.) та ін. К. : «Аконіт», 2008. Т. 3 П-Я / уклад.: В. В. Яременко, О. М. Сліпушко. 2008. $862 \mathrm{c}$.

6. Науково-практичний коментар Кримінального кодексу України / за заг. ред. О. М. Литвинова. К. : «Центр учбової літератури», 2016. 528 с.

7. Кримінальний процесуальний кодекс України : чинне законодавство України зі змінами та доповненнями станом на 11 червня 2018 р. (відповідає офіційному текстові). К. : «Центр учбової літератури», 2018. 268 с.

8. Текст проєкту нового Кримінального кодексу України. URL: https://newcriminalcode.org.ua/upload/media/2021/01/18/kontrolnyj-proekt-kk-17-01-2021.pdf (дата звернення: 26.02.2021).

9. Проєкт Закону № 4335 від 06.11.2020 «Про обіг цивільної вогнепальної зброї та бойових припасів до неї» та альтернативний Проєкт Закону № 4335-1 від 24.11.2020 «Про цивільну зброю та боєприпаси». URL: https://w1.c1.rada.gov.ua/pls/zweb2/webproc4_1?pf3511=70363 (дата звернення: 26.02.2021).

\footnotetext{
${ }^{5}$ Кримінальний кодекс України. Відомості Верховної Ради України. 2001. № 25-26. CT. 131. URL: https://zakon.rada.gov.ua/laws/show/2341-14\#Text (дата звернення: 26.02.2021).
} 
10. Кваша О. О. Кримінологічна теорія і практика: досвід, проблеми сьогодення та шляхи їх вирішення : матеріали міжвузів. наук.-практ. круглого столу : у 2 ч. / за ред. В. В. Чернєй, С. Д. Гусарєв, С. С. Чернявський та ін. Київ : Нац. Акад. внутр. справ, 2020. Ч. 1 : Легітимація статусу «злодій у законі» як панацея в протидії організованій злочинності в Україні. С. 68-70.

11. Харитонова О. В., Тітко I. М. Злочин, пов'язаний $з$ домашнім насильством: правові проблеми та практичні рекомендації. https://jurliga.ligazakon.net/ua/analitycs/192450_zlochin-povyazaniy-z-domashnm-nasilstvompravov-problemi-ta-praktichn-rekomendats (дата звернення: 26.02.2021).

\section{References}

1. Velykyi tlumachnyi slovnyk suchasnoi ukrainskoi movy (z dod., dopov. ta CD) [Large explanatory dictionary of the modern Ukrainian language (with appendix, supplement and CD)] / uklad. i holov. red. V. T. Busel. K. : Irpin : VTF «Perun», 2009. 1736 s. [in Ukrainian].

2. Etymolohichnyi slovnyk ukrainskoi movy : u 7 t. [Etymological dictionary of the Ukrainian language : in 7 vols.] / redkol.: O. S. Melnychuk (holov. red.) ta in. K. : Nauk. dumka, 1983. T. 5 R-T / uklad.: R. V. Boldyriev ta in. 2006. 704 s. [in Ukrainian].

3. Kryminalnyi kodeks Ukrainy : naukovo-praktychnyi komentar. Vydannia vosme, pereroblene ta dopovnene [Criminal Code of Ukraine : Scientific and practical commentary] / vidp. red. Ye. L. Streltsov. Kh. : Odissei, 2012. 904 s. [in Ukrainian].

4. Etymolohichnyi slovnyk ukrainskoi movy : u 7 t. [Etymological dictionary of the Ukrainian language : in 7 vols.] / redkol.: O. S. Melnychuk (holov. red.) ta in. K. : Nauk. dumka, 1983. T. 6 U-Ya / uklad.: H. P. Pivtorak ta in. 2012. 568 s. [in Ukrainian].

5. Novyi tlumachnyi slovnyk ukrainskoi movy : u 3 t. [New explanatory dictionary of the Ukrainian language : in 3 vols.] / redkol.: O. A. Amatuni (holov. red.) ta in. K. : «Akonit», 2008. T. 3 P-Ya / uklad.: V. V. Yaremenko, O. M. Slipushko. 2008. 862 s. [in Ukrainian].

6. Naukovo-praktychnyi komentar Kryminalnoho kodeksu Ukrainy [Scientific and practical commentary on the Criminal Code of Ukraine] / za zah. red. O. M. Lytvynova. K. : «Tsentr uchbovoi literatury», 2016. 528 s. [in Ukrainian].

7. Kryminalnyi protsesualnyi kodeks Ukrainy [Criminal Procedure Code of Ukraine] : chynne zakonodavstvo Ukrainy zi zminamy ta dopovnenniamy stanom na 11 chervnia $2018 \mathrm{r}$. (vidpovidaie ofitsiinomu testovi). K. : «Tsentr uchbovoi literatury», 2018. 268 s. [in Ukrainian].

8. Tekst proiektu novoho Kryminalnoho kodeksu Ukrainy [The text of the draft of the new Criminal Code of Ukraine]. https://newcriminalcode.org.ua/upload/media/2021/01/18/kontrolnyj-proekt-kk-17-01-2021.pdf (data zvernennia: 26.02.2021) [in Ukrainian].

9. Proiekt Zakonu № 4335 vid 06.11.2020 «Pro obih tsyvilnoi vohnepalnoi zbroi ta boiovykh prypasiv do nei» ta alternatyvnyi Proiekt Zakonu № 4335-1 vid 24.11.2020 «Pro tsyvilnu zbroiu ta boieprypasy» [Draft Law № 4335]. URL: https://w1.c1.rada.gov.ua/pls/zweb2/webproc4_1?pf3511=70363 (data zvernennia: 26.02.2021) [in Ukrainian].

10. Kvasha, O. O. (2020). Kryminolohichna teoriia i praktyka: dosvid, problemy sohodennia ta shliakhy yikh vyrishennia : materialy mizhvuziv. nauk.- prakt. kruhloho stolu : u $2 \mathrm{ch}$. [Criminological theory and practice: Experience, Problems of the present and ways to solve them : Materials of the interuniversity scientific and practical round table : $2 \mathrm{v}$.] / za red. V. V. Cherniei, S. D. Husariev, S. S. Cherniavskyi ta in. Kyiv : Nats. Akad. vnutr. Sprav. Ch. 1 : Lehitymatsiia statusu «zlodii u zakoni» yak panatseia v protydii orhanizovanii zlochynnosti v Ukraini. S. 68-70 [in Ukrainian].

11. Kharytonova O. V, Titko I. M. Zlochyn, poviazanyi z domashnim nasylstvom: pravovi problemy ta praktychni rekomendatsii [Crime related to domestic violence: Legal problems and practical recommendations]. URL: https://jurliga.ligazakon.net/ua/analitycs/192450_zlochin- 
povyazaniy-z-domashnm-nasilstvom-pravov-problemi-ta-praktichn-rekomendats (data zvernennia: 26.02.2021) [in Ukrainian].

Komissarov Mykola,

$\mathrm{PhD}$ in Law, Associate Professor

(Donetsk State University of Internal Affairs, Kryvyi Rih)

ORCID: https://orcid.org/0000-0001-6828-7974

Komissarova Natalia,

$\mathrm{PhD}$ in Law, Associate Professor

(Donetsk State University of Internal Affairs, Kryvyi Rih)

ORCID: https://orcid.org/0000-0001-6895-6891

\section{TERMINOLOGY OF CRIMINAL LAW}

In this article questions about the expediency of using semantically accurate and clear terms in normsetting that as correctly as possible denote acts, things, or persons because of the illegal actions or corpus delicti which are described in the relevant article of the Ukrainian Criminal Code are considered. On the example of several articles of current Ukrainian Criminal Code approaches of improving regulatory acts by using successful legal and common terms are being proposed. Criteria that could be a foundation when creating and improving legislation in general and criminal in particular being considered. Being proposed particular, more accurate, terms for replacement of the current, but not appropriate terms. Emphasis is placed on that each legal act should be write down very clear for ordinary people to increase the efficiency of positive criminal liability institution. Being determined main types of misuse of terms, which includes the use of terms without considering their content load by lawmakers; lawmakers' use of terms taking into account pre-determined actions that are not reflected in the body of the law but are marked by an unfortunate term, or use specific terms where their use is inappropriate. Taking everything above into account and considering the prevalence of legal terminology outside the professional community, questions related to the accuracy, intelligibility, simplicity, clarity of legal language are emphasized, in particular terminology of criminal law. Works of the most popular scientists whether in the field of legal terms or in the field of criminal law are analyzed. It is argued that the clarity of the legal norm, criminal law, in particular, will avoid arbitrariness and abuse by law enforcement agencies and more effectively implement the concept of positive criminal liability in society.

Key words: criminal law; terminology; legal terminology; rule-making; terminology; law.

Надіслано до редколегії 09.04.2021

Рекомендовано до публікації 16.04.2021 
УДК: 343.343.3

DOI: https://doi.org/10.32366/2523-4269-2021-75-2-74-87

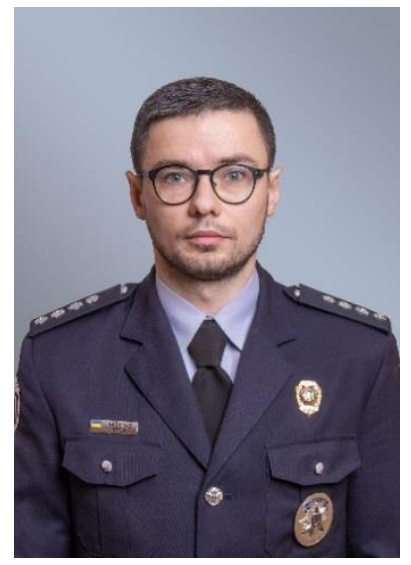

\title{
Назимко Єгор Сергійович,
}

доктор юридичних наук, старший науковий співробітник

(Донецький державний університет внутрішніх справ, м. Маріуполь)

ORCID: https://orcid.org/0000-0003-4949-4155

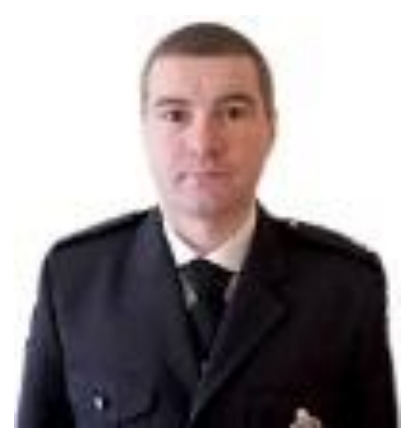

\author{
Демчишин Дмитро Анатолійович, \\ викладач \\ (Донецький державний університет \\ внутрішніх справ, м. Маріуполь) \\ ORCID: https://orcid.org/0000-0002-4172-1272
}

\section{СОЦІАЛЬНА ОБУМОВЛЕНІСТЬ КРИМІНАЛЬНО- ПРАВОВОЇ ЗАБОРОНИ ХУЛІГАНСЬКИХ ДІЙ}

У статті досліджено соціальну обумовленість кримінальноправової заборони хуліганських дій. Обтрунтовано доцільність аналізу сочіальної обумовленості кримінально-правової заборони хуліганських дій як наскрізної кримінально-правової категорії 3 урахуванням системних зв'язків між усіма складами злочинів, конструктивною ознакою яких є хуліганські діï. Визначено систему обставин соиіальної обумовленості кримінально-правової заборони хуліганських дій, яка передбачає історичні, прогностичні, технікоюридичні обставини. У результаті дослідження встановлено, шоо кримінально-правова заборона хуліганських дій на рівні ст. 296 КК України є не повною мірою сочіально обумовленою. Саме діяння «хуліганство»є шттучним для України з історичної точки зору, кримінально-правова заборона не відповідає украӥнській ментальності, пересічні громадяни переважно не сприймають хуліганство як злочин, хуліганство не узгоджується повністю із сучасною парадигмою розвитку суспільних відносин. Доведено, щуо через абстрактність розуміння громадського порядку існує складність його сприйняття як об'єкта хуліганства. Зауважено, щзо кваліфікуючі ознаки хуліганства не відповідають ознакам системності та нормативної несуперечливості. Констатовано, що редакиї ст. 296 КК України властиві неточності формулювань. Це в иілому призводить до наявності суперечностей між нормами КК України, наділяе суд та правоохоронні органи надмірними дискреційними повноваженнями.

(C) Назимко Єгор Сергійович,

Демчишин Дмитро Анатолійович, 2021 
Ключові слова: сочіальна обумовленість; кримінально-правова заборона; хуліганство; наскрізна категорія; обставина; очіночне поняття.

Постановка проблеми. Існування будь-якої правової норми має бути соціально обумовленим. У суспільства має бути сформована потреба, так зване «соціальне замовлення» на наявність у правовій системі певних правових норм. Зрозуміло, що людство за період свого існування сформувало ціннісні базові правові норми для регулювання суспільних відносин. В окремих суспільств (народів) $є$ правові норми, які не притаманні іншим суспільствам (народам). Однак правові норми в будь-якому суспільстві є завжди соціально обумовленими.

Що ж стосується кримінально-правових норм, то їм з огляду на правову природу кримінального права має бути властива виключна соціальна обумовленість. У правовій науці соціальна обумовленість найчастіше визначається як «відповідність абстрактних юридичних установлень об'єктивним закономірностям суспільного розвитку та визнається одним 3 показників досконалості законодавства. Останнє, у свою чергу, є важливою умовою ефективності правових норм та інститутів» [13, с. 30].

Суспільна небезпечність кожного кримінально караного діяння є тим критерієм, яким керується законодавець під час диференціації кримінальної відповідальності, а суб'єкти правозастосування - під час індивідуалізації. Як справедливо зазначає О. О. Пащенко, «обумовленість кримінального права законами суспільного розвитку, всією системою соціальних відносин знаходить вираз як у його фундаментальних принципах, так і в змісті конкретних заборон, які визначені кримінальним законодавством. Об'єктивні соціальні потреби формують зміст закону про кримінальну відповідальність не безпосередньо, а проходячи через свідомість і волю законодавця. Тому закони про кримінальну відповідальність можуть адекватно відображати суспільну потребу або недостатньо відповідати цій потребі, досягати чи не досягати поставлених законодавцем цілей» [20, с. 12]. Кримінальний закон уважається соціально обумовленим тільки в тому разі, коли відображає потреби суспільства в кримінально-правовій охороні умов свого розвитку, інакше кажучи, суспільну необхідність криміналізації певних діянь, які посягають на ці умови [7, с. 14].

У сучасній кримінально-правовій системі України хуліганські дії є наскрізною категорією, яка охоплює не тільки окремий склад злочину - ст. 296 Кримінального кодексу України (далі - КК України), але й кваліфікуючу ознаку умисного вбивства - вбивства 3 хуліганських мотивів (п. 7 ч. 2 ст. 115 КК України); кваліфікуючу ознаку наруги над могилою, іншим місцем поховання або над тілом померлого (ч. 3 ст. 297 КК України); ознаку альтернативного діяння основного складу злочину жорстоке поводження з тваринами (ст. 299 КК України). Хоча «в реальній дійсності з хуліганських мотивів учиняється значно більше видів злочинів, особливо таких, які раніше кваліфікувалися за складом хуліганства, але відповідно до чинного КК України підпадають під ознаки окремих самостійних статей: перешкоджання здійсненню релігійного обряду (ст. 180 КК України); завідомо неправдиве повідомлення про загрозу безпеці громадян, знищення чи пошкодження об'єктів власності (ст. 259 КК України); самовільне без нагальної потреби зупинення поїзда (ст. 283 КК України); наруга над державними символами (ст. 338 КК України) тощо» [18, с. 169-170].

Тому аналіз соціальної обумовленості кримінально-правової заборони хуліганських дій як наскрізної кримінально-правової категорії має відбуватися з урахуванням системних зв'язків між усіма складами злочинів, конструктивною ознакою яких є хуліганські дії.

Аналіз останніх досліджень та публікацій. Необхідно зазначити, що соціальна обумовленість кримінально-правових заборон стала предметом наукових досліджень у другій половині XX ст. У сучасній кримінально-правовій доктрині питання соціальної обумовленості кримінально-правових норм розглядалося такими вченими, як Д. С. Азаров, П. П. Андрушко, В. І. Борисов, В. В. Голіна, О. П. Горох, Н. О. Гуторова, О. О. Дудоров, М. Й. Коржанський, В. М. Кудрявцев, В. В. Кузнєцов, М. І. Мельник, В. А. Мисливий, А. А. Музика, В. О. Навроцький, А. М. Орлеан, О. О. Пащенко, В. В. Сташис, С. Л. Стрельцов, В. Я. Тацій, Є. В. Фесенко, М. І. Хавронюк та деякими іншими. 
Слід зауважити, що у сфері кримінально-правової заборони хуліганських дій бракує соціологічних досліджень. Так, ученими звертається увага на соціальну обумовленість криміналізації хуліганства. Однак криміналізація $\epsilon$ законодавчим процесом створення кримінально-правового припису. Соціальна ж зумовленість існування та застосування цього припису $\epsilon$ категорією більш широкою, оскільки вводить у дію прогностичні завдання криміналізації у процес регулювання суспільних відносин.

Метою статті $є$ дослідження соціальної обумовленості кримінально-правової заборони хуліганських дій та на цій основі встановлення відповідності суспільному запиту ст. 296 КК України.

Виклад основного матеріалу. Зазначені нами вище нормативні приписи кримінального законодавства спрямовані на забезпечення охорони суспільних відносин у сфері громадського порядку від хуліганських зазіхань, охорону моральності, життя, здоров'я людини тощо. Ці нормативні приписи $є$ охоронними 3 точки зору кримінально-правового регулювання та «слугують юридичною гарантією захисту відповідних регулятивних правовідносин. Для того, щоб виконувати роль такої гарантії, згадані норми повинні захищати лише ті суспільні відносини, рівень соціальної цінності яких $є$ достатнім для кримінально-правової охорони. У цьому простежується зв'язок даної обставини соціальної обумовленості з іншою - наявністю можливості боротьби з діянням завдяки кримінально-правовим засобам. Звичайно, йдеться про таку складову останньої, як «неможливість боротьби за допомогою інших заходів» [21, с. 180].

Щоб довести або спростувати соціальну обумовленість охоронних кримінальноправових норм, в «ідеалі» слід установити факт відповідності нормативних приписів КК України певним соціальним та техніко-юридичним критеріям. Стосовно кола таких критеріїв учені висловлюють різні думки. Згідно 3 позицією О. С. Іоффе та М. Д. Шаргородського, основи криміналізації в процесі правотворчості досить стабільні та передбачають: а) вивчення соціальних, економічних та інших об'єктивних процесів життя суспільства, що зумовлюють його поступальний розвиток; б) дослідження тенденцій, динаміки та структури антисуспільних явищ, у тому числі і злочинності; розгляд їх причин; прогнозування можливих змін у них; в) аналіз та оцінку ефективності заходів боротьби зі злочинністю, включаючи заходи кримінально-правового характеру; г) порівняльно-правове вивчення методів боротьби зі злочинністю в зарубіжних державах; г) забезпечення на цій основі послідовного перспективного планування законодавчої діяльності в галузі кримінального права, вдосконалення організації і діяльності правоохоронних органів [8, с. 1920]. В. І. Борисов наполягає на тому, що соціально-правова обумовленість кримінального закону визначається різноманітними за значущістю соціальними, економічними, політичними, психологічними, правовими та іншими чинниками, встановлення і розкриття яких дає можливість пояснити необхідність кримінально-правової охорони певних суспільних відносин, прогнозувати розвиток тих чи інших інститутів кримінального законодавства, підвищити обгрунтованість змісту закону [4, с. 28]. В. І. Осадчий виділяє кримінологічний, нормативно-правовий, історичний та міжнародний фактори соціальної обумовленості кримінально-правового захисту правоохоронної діяльності [19, с. 72-73]. С. В. Гізімчук називає факторами (а фактично - підставами) криміналізації порушення правил, норм, стандартів, що забезпечують безпеку дорожнього руху, такі: соціально-економічні, технічні, нормативні та кримінологічні [5, с. 5-6].

Зважаючи на погляди В. О. Навроцького, до соціальної обумовленості слід зараховувати соціальні та соціально-психологічні фактори, що обумовлюють суспільну необхідність і політичну доцільність установлення кримінальної відповідальності за те чи інше діяння (до них відносять суспільну небезпечність діяння, його значну поширеність, домірність позитивних і негативних наслідків криміналізації та кримінально-політичну адекватність криміналізації [16, с. 114]). Ю. Е. Пудовкін до системи соціальної обумовленості кримінально-правової заборони включає: соціально-кримінологічні засади кримінальноправової заборони; етичні засади кримінально-правової заборони; міжнародно-правові засади кримінально-правової заборони; культурно-історичні засади кримінально-правової заборони 
[24, с. 141-176]. В. В. Кузнєцов до факторів, що стали рушійними під час вдосконалення КК України, відносить: міжнародно-правовий, конституційно-правовий, судовий, економічний, політичний, кримінологічний, соціально-правовий і нормативний фактори [15, c. 38].

Як зазначає Т. В. Столяр, у науці кримінального права виділяють шість ключових підстав криміналізації: 1) несприятлива динаміка певного виду суспільно небезпечних діянь, які раніше не становили складу злочину; 2) виникнення або суттєвий розвиток нової групи суспільних відносин, що відбувається в результаті економічного чи технічного прогресу; 3) виявлення шкідливих наслідків господарської чи іншої діяльності людей, у зв'язку з чим виникає потреба в обмеженні форм і меж такої діяльності; 4) суттєва та раптова зміна соціального, економічного або політичного стану, що може зумовити превентивну криміналізацію, яка здійснюється ще до того, як можливі суспільно небезпечні дії набудуть реального поширення; 5) такий розвиток суспільства, що визначає нетерпимість, особливу небезпеку певних дій, з якими раніше доводилося (або була можливість) миритися, але за нових умов подібні дії суперечать панівному ладу суспільних відносин або отримано реальну базу для їх викорінення; 6) необхідність виконання зобов'язань за міжнародними угодами [25, с. 224]. М. М. Комарницький обмежується аналізом історичних, соціальнопсихологічних, нормативних, кримінологічних i міжнародних факторів соціальної обумовленості встановлення відповідальності за злочини проти осіб чи їх близьких родичів [13, с. 37]. I. М. Федулова виділяє такі ключові підстави криміналізації: суспільна небезпека, співвідношення позитивних і негативних наслідків криміналізації, можливість боротьби 3 діянням за допомогою кримінально-правових заходів і неможливість боротьби за допомогою інших [27, с. 89].

Варто звернути увагу, що розгляд соціальних факторів соціальної обумовленості кримінально-правової заборони в «чистому» вигляді порушує закони формальної логіки, оскільки частина (фактор) цілого (соціальна обумовленість), як стає зрозумілим, є більш широким поняттям. Тому розгляд соціальних факторів соціальної обумовленості кримінально-правової заборони хуліганських дій у цілому залишається за межами нашого дослідження.

Слід наголосити, що визначення соціальної обумовленості існування кримінальноправових норм через групування за факторами становить проблему, яка може бути досліджена в різних аспектах та за різними напрямами. Так, дослідники виділяють критерії, принципи, підстави, передумови, умови, приводи, способи цього виду законодавчої діяльності. Ці фактори тісно переплітаються та взаємодіють, однак часто є майже тотожними явищами [17, c. 154-155]. Окремі вчені до підстав кримінально-правової заборони відносять такі: 1) суспільну небезпечність - неможливо встановити універсальний критерій, за яким можна було б визначити достатній для криміналізації ступінь суспільної небезпечності. У ході обговорення кожної кримінально-правової новели необхідно вирішувати питання про наявність такої у конкретного виду діянь. Суспільною небезпечністю охоплюється наявність досить значної матеріальної або моральної шкоди, що завдається суспільству, яка, у свою чергу, впливає на пеналізацію і не є самостійною підставою криміналізації; 2) типовість та достатню розповсюдженість антисуспільної поведінки, але 3 урахуванням ступеня іï суспільної небезпечності; 3 ) динаміку суспільно небезпечних діянь 3 урахуванням причин та умов, що їх породжують; 4) необхідність впливу кримінально-правовими заходами, при цьому потрібно враховувати, що кримінальна репресія - це крайня форма протидії найбільш небезпечним формам девіантної поведінки. Криміналізація діяння доречна тільки тоді, коли немає та не може бути норми, яка б досить ефективно регулювала відповідні відносини методами інших галузей права; 5) врахування можливостей системи кримінальної юстиції в протидії тим чи іншим формам антисуспільної поведінки та наявність матеріальних ресурсів для реалізації кримінально-правової заборони; 6) співрозмірність позитивних та негативних наслідків криміналізації [3, с. 146-147]. 
Нам імпонує сучасний доктринальний підхід, запропонований О. О. Пащенком. Для охоронних кримінально-правових норм обов'язковими обставинами соціальної обумовленості $\epsilon$ такі: суспільна корисність, системно-правова несуперечливість, чіткість і ясність мови, відповідність історичним традиціям або змінам у суспільному житті (альтернативно), наявність можливості боротьби із суспільно небезпечним діянням кримінально-правовими засобами, наявність ресурсів для здійснення кримінального переслідування осіб, які вчинили суспільно небезпечні діяння, співрозмірність позитивних і негативних наслідків кримінальноправової заборони, повнота й ненадмірність кримінально-правової заборони [21, с. 376].

3 урахуванням предмета нашого дослідження та наведених вище поглядів учених пропонуємо виокремити такі обставини соціальної обумовленості кримінально-правової заборони хуліганських дій:

- $\quad$ історичні (відповідність історичним традиціям або змінам у суспільному житті);

- прогностичні (наявність можливості запобігання суспільно небезпечним діянням кримінально-правовими засобами, суспільна корисність та кримінально-політична адекватність криміналізації (співрозмірність позитивних і негативних наслідків кримінальноправової заборони), наявність ресурсів для здійснення кримінального переслідування осіб, які вчинили суспільно небезпечні діяння);

техніко-юридичні (системно-правова несуперечливість, чіткість і ясність мови, повнота й ненадмірність кримінально-правової заборони).

Спробуємо розглянути зазначені обставини більш детально.

Історичні обставини (відповідність історичним традиціям або змінам у суспільному житті) демонструють, наскільки у процесі існування та реалізації кримінально-правової заборони враховується рівень суспільної правосвідомості та психології, а також історичні традиції.

За справедливим твердженням правників, визнання діяння кримінально караним повинно бути схвалено суспільством. У кожному конкретному випадку перед уведенням чи відміною кримінально-правової заборони необхідним $є$ ретельне вивчення правових уявлень у суспільстві стосовно діяння, яке підлягає криміналізації. Однак оцінка суспільних поглядів не повинна обмежуватися тільки правовими ідеями. Важливим є вивчення історичних, моральних та інших уявлень, які є значущими для кожного конкретного випадку [3, с. 147]. Щодо історії відповідальності за хуліганство на українських землях, то нами встановлено, що саме діяння «хуліганство» $є$ штучним для України з історичної точки зору. Воно як окремий склад злочину офіційно виникло в радянський період, існувало протягом усього радянського часу та відобразилося в КК України 2001 р. Автентичності цієї заборони українській ментальності не простежується. Історичні традиції заборони бешкетницьких дій були, проте вони були пов'язані взагалі з правовим статусом особи, яка вчиняє подібне бешкетництво (відповідальне або особливо відповідальне становище), або з місцем вчинення такого діяння, що має особливе значення для громади. Необхідно зазначити, що вітчизняними вченими проводилося вивчення суспільної думки щодо сприйняття хуліганства. Так, за результатами проведеного українськими кримінологами опитування пересічних громадян, які не мають спеціальних знань у галузі права, було встановлено, що 75 \% респондентів розуміють поняття «хуліганство» саме як дрібне правопорушення, 14 \% як аморальні, антисуспільні дії, за вчинення яких в Україні не передбачена відповідальність, і лише 11 \% уважають хуліганство злочином [11, с. 94-97].

Тому маємо погодитися 3 тезою про те, що нині закріплення хуліганства у кримінальному законодавстві (на рівні ст. 296 КК України. - Є. Н., Д. Д.) не відповідає суспільній небезпеці такого діяння, оскільки в суспільстві відбулися зміни морально-етичних орієнтирів, через що типове хуліганство не становить тієї суспільної небезпеки для пересічного громадянина, якій слід запобігати кримінальними покараннями. До того ж відповідальність за подібні дії вже закріплена в інших статтях Особливої частини КК України [26, с. 157]. 
Звичайний громадянин не сприймає тієї суспільної небезпеки, яка закріплена за хуліганством у кримінальному законодавстві, і пояснення цьому знаходить своє відображення в історії. Хуліганство як окремий злочин набуло свого поширення в радянські часи, коли існувала потреба захищати інтереси громади та держави, а не індивіда, коли публічний інтерес мав значну перевагу над приватним. Нині така потреба зникла, боротьба з хуліганами не характеризується такими масштабами, як це було більше чверті століття тому [26, с. 159]. У зв'язку із зазначеним маємо констатувати відносну відповідність ст. 296 КК України історичним традиціям та групі обставин, що соціально зумовлюють наявність цієї кримінально-правової заборони.

Прогностичні обставини насамперед змушують знайти відповідь на питання про наявність можливості запобігання хуліганству кримінально-правовими засобами. Для цього слід установити, чи дійсно кримінально-правова заборона є запобіжним чинником учинення хуліганства, тобто чи усвідомлює особа на рівні сприйняття права те, що за вчинення хуліганства настає кримінальна відповідальність. Певні аргументи 3 цього приводу було наведено вище. Однак наявність ст. 296 КК України та відповідна правозастосовна практика засвідчує, що можливість запобігання кримінальними заборонами хуліганству є, вона існує. Тільки варто відповісти на запитання: 3 чим ми все ж таки боремося? Для цього маємо звернутися до питання суспільної небезпечності хуліганства.

У науці кримінального права $є$ усталеним підхід стосовно того, що суспільна небезпечність кримінального правопорушення залежить від двох основних критеріїв - об'єкта злочину та інтенсивності злочинного посягання. Об'єктом хуліганства є громадський порядок. Відповідно до ст. 3 Конституції України, людина, іiї життя і здоров'я, честь і гідність, недоторканність і безпека визнаються в Україні найвищою соціальною цінністю. Тому громадський порядок певним чином можна віднести до категорії безпеки, саме тієї категорії, що забезпечує безпеку членів суспільства. У загальному розумінні громадський порядок - це «сукупність суспільних відносин, що забезпечують нормальні умови життєдіяльності людини, діяльності підприємств, установ та організацій шляхом встановлення, дотримання і реалізації правових та етичних норм» [1, с. 654]. Вищий спеціалізований суд України з розгляду цивільних і кримінальних справ зазначає, що громадський порядок - це стан суспільних відносин, що виник, сформувався, змінюється та існує під впливом дії правових норм (значною мірою), моральних засад, звичаїв, етичних правил, традицій, інших позаюридичних чинників і знаходить свій вияв (відображення) у безпечності громадського спокою, охороні здоров'я, честі та гідності людини, іiї прав та свобод, зокрема: права на відпочинок, усталених правил співжиття, комунікації (спілкування), у поведінці в побуті, у повазі та ставленні членів спільноти один до одного, у нормальному функціонуванні органів державної влади, місцевого самоврядування, різних установ, організацій, громадських об'єднань, інших інституцій, які займаються корисною суспільною діяльністю [10]. Як бачимо, взагалі «кожне правопорушення посягає на громадський порядок і може завдати або завдає йому шкоди, адже ігнорування встановлених норм поведінки і $є$ порушенням цього громадського порядку» [26, с. 157]. Як зауважується в листі зазначеної вище судової установи, «за зовнішнім виявом (набором фактів) хуліганство певним чином схоже на ряд інших діянь, зокрема найбільше на ті 3 них, які посягають на здоров'я, честь та гідність людини, іiі майно» [10]. Тому існує складність сприйняття громадського порядку як об'єкта хуліганства, а надто - встановлення конкретної шкоди для суспільних відносин, що утворюють зміст цього об'єкта.

Щодо інтенсивності впливу вчинення хуліганства на громадський порядок маємо наголосити, що воно має найбільш негативну інтенсивність серед усіх правопорушень, що посягають саме на громадський порядок. Хуліганство здійснюється в активній формі, здебільшого з ініціативи правопорушника або через використання незначного (нікчемного) приводу, як правило, відбувається в публічних (громадських, людних) місцях, супроводжується ненормативною (брутальною, нецензурною) лексикою та/або фізичним насильством, зокрема із використанням травмуючих властивостей таких предметів, як вогнепальна зброя, і призводить до заподіяння моральної та матеріальної шкоди [10]. Ця 
інтенсивність також характеризується такими ознаками, як «грубе порушення», «явна неповага до суспільства», «зухвалість» та «винятковий цинізм». Слід продовжити наукову дискусію, яку розпочали вітчизняні вчені, про те, чи не скоюються ще злочини, що посягають на інші об'єкти кримінально-правової охорони, з притаманними ознаками грубого порушення, явної неповаги до суспільства, зухвалості та виняткового цинізму? Наприклад, чи не вчиняється опір представникові влади, працівникові правоохоронного органу, члену громадського формування 3 охорони громадського порядку i державного кордону або військовослужбовцеві (ст. 342 КК України) із зазначеними ознаками? Навіщо тоді в ч. 3 ст. 296 КК України передбачено такий кваліфікований склад, як хуліганство, «пов'язане з опором представникові влади або представникові громадськості, який виконує обов'язки з охорони громадського порядку, чи іншим громадянам, які припиняли хуліганські дії»? Певні слушні міркування щодо цього висловлює Г. І. Піщенко і наполягає на виключенні з кваліфікованого складу хуліганства опору представникові влади або представникові громадськості, які виконували обов'язки з охорони громадського порядку. Науковець наводить низку аргументів 3 цього приводу: «1) опір зазначеним особам свідчить про особливу зухвалість тих, хто його вчиняє; 2) родовим об'єктом опору є порядок управління, а хуліганства - громадський порядок. У свою чергу, різними є й безпосередні об'єкти. Дана обставина веде до змішування останніх; 3) хуліганством охоплюється багато інших складів злочинів, закріплених у КК України як самостійні, але законодавець їх не вніс як кваліфікуючі ознаки хуліганства; 4) опір указаним категоріям осіб може бути наданий у ході припинення будь-якого злочину, але в жодній статті КК України (крім хуліганства) він не закріплений як кваліфікуюча ознака») [28, c. 78-79].

Подібні твердження трапляються в науковій літературі і щодо інших кваліфікуючих ознак хуліганства. На думку О. О. Дудорова та М. І. Хавронюка, «стаття 296 КК України $є$ однією із тих статей, за якими суди найчастіше засуджують до реального позбавлення волі... Судячи із суворості покарання, що призначається судами від імені держави, хуліганство $є$ більш небезпечним для держави і суспільства злочином, ніж, скажімо, злочини у сфері службової діяльності і злочини проти довкілля... Найбільша проблема криміналізації хуліганства полягає в тому, що ст. 296 КК України перевантажена оціночними ознаками, які слідчі, прокурори й суди застосовують практично кожен на свій розсуд» [6, с. 708]. Тому й оцінити інтенсивність впливу хуліганства на наявний стан суспільних відносин у цілому неможливо. А кваліфікуючі ознаки хуліганства $\epsilon$, на наш погляд, випадковим набором найбільш розповсюджених характеристик учинення хуліганства. Так само можна було б включити до кваліфікуючих ознак вчинення хуліганства нанесення тілесних ушкоджень (середньої тяжкості та тяжких), незаконне заволодіння транспортним засобом тощо.

Щодо співрозмірності позитивних та негативних наслідків кримінально-правової заборони, то в цьому питанні також не все так однозначно. За наявності якісного та ефективного кримінального закону, за умови його правильного та об'єктивного застосування апріорі майже відсутні негативні наслідки криміналізації діяння [12, с. 112]. Як уже зазначалося, за хуліганство в нашій країні карають суворіше, ніж за злочини проти екології та корупційні злочини. Хуліганству як факту та як виду соціально негативної практики треба запобігати не покаранням, а іншими заходами соціального та правового впливу. Що ж стосується політичної адекватності, то аналізований склад злочину був політично відповідним у певний історичний період розвитку нашої держави у складі Союзу Радянських Соціалістичних Республік (далі - СРСР). Кримінальне законодавство зарубіжних країн узагалі не містить і ніколи не містило такого складу злочину, як хуліганство. Досліджувана стаття закріплює відповідальність за посягання на ті суспільні відносини, які вже охороняються кримінальним законом: життя, здоров'я, власність, довкілля [14, с. 114-115; 26, с. 158]. Щодо наявності ресурсів для здійснення кримінального переслідування осіб, які вчинили хуліганство, то, безумовно, в держави є необхідні ресурси в межах органів та підрозділів Національної поліції України або інших правоохоронних органів (з урахуванням статусу суб'єкта злочину). 
Окремі техніко-юридичні обставини соціальної обумовленості кримінально-правової заборони хуліганських дій (системно-правова несуперечливість, чіткість і ясність мови) було розглянуто вище. Тому звернемо увагу на найбільш важливі аргументи.

Маємо зауважити, що чинна редакція ст. 296 КК України характеризується окремими рисами суперечливості положень. У п. 4 постанови Пленуму Верховного Суду України «Про судову практику у справах про хуліганство» від 22 грудня 2006 р. № 10 вказується: «Дії, що супроводжуються погрозами вбивством, завданням побоїв, заподіянням тілесних ушкоджень, вчинені винним щодо членів сім’і, родичів, знайомих і викликані особистими неприязними стосунками, неправильними діями потерпілих тощо, слід кваліфікувати за статтями КК України, що передбачають відповідальність за злочини проти особи. Як хуліганство зазначені дії кваліфікують лише в тих випадках, коли вони були поєднані з очевидним для винного грубим порушенням громадського порядку 3 мотивів явної неповаги до суспільства та супроводжувалися особливою зухвалістю чи винятковим цинізмом» [23]. Сам суд не надає чіткого розмежування хуліганства від інших видів злочину. Навіть злочин, скоєний на фоні особистих неприязних стосунків, слід кваліфікувати як хуліганство у випадку встановлення ознак, які мають неприхований оціночний характер.

Учені неодноразово звертали увагу на неповноту та недоліки конструювання таких оціночних понять, як «грубе порушення», мотив «явної неповаги до суспільства», «особлива зухвалість» та «винятковий цинізм»; неможливість розмежування зухвалості та особливої зухвалості, цинізму та виняткового цинізму [26, с. 157]. Ще одним з негативних наслідків закріплення хуліганства у Кримінальному кодексі України $\epsilon$ можливе виникнення таких ситуацій, коли правоохоронні органи затримують порушника громадського порядку, але за відсутності в його діях складу будь-якого злочину особу все одно притягують до відповідальності за хуліганство. Така ситуація склалася через відсутність у статті 296 КК України переліку конкретних дій, які б дозволяли зробити обгрунтований висновок про вчинення особою саме хуліганства; у самій статті 296 КК України не визначено жодної реальної дії, яка б дозволила виділити хуліганство в окремий злочин із власним об'єктом посягання [26, с. 159]. Таким чином, доцільно констатувати, що редакції ст. 296 КК України властива неточність формулювань, що в цілому призводить до існування суперечності між нормами КК України, наділяє суд та правоохоронні органи надмірними дискреційними повноваженнями.

Щодо відповідності міжнародно-правовим договорам (зобов'язанням), то варто вказати на відсутність прямих міжнародно-правових актів, особливо зобов'язань України перед міжнародною спільнотою про встановлення кримінальної відповідальності за хуліганство. Зрозуміло, що існує низка міжнародних документів, які зобов'язують установлювати кримінальну відповідальність за посягання на додаткові соціальні цінності, яким опосередковано завдається шкода під час вчинення хуліганства. Однак жодним міжнародним документом не закріплено вимогу до національних законодавств щодо необхідності криміналізації хуліганства. Питання встановлення кримінальної відповідальності за хуліганські дії віднесено до внутрішніх національних питань кримінально-правової політики.

Висновки. Отже, нами було досліджено соціальну обумовленість кримінальноправової заборони хуліганських дій. Зважаючи на те, що в сучасній кримінально-правовій системі України хуліганські дії є не тільки складом злочину, а й ознаками інших складів злочину, обгрунтовано доцільність аналізу соціальної обумовленості кримінально-правової заборони хуліганських дій як наскрізної кримінально-правової категорії з урахуванням системних зв'язків між усіма складами злочинів, конструктивною ознакою яких $є$ хуліганські діï.

3 огляду на особливості призначення нормативних приписів КК України, що забороняють хуліганські дії, у системі кримінально-правового регулювання визначено систему обставин соціальної обумовленості кримінально-правової заборони хуліганських дій: історичні (відповідність історичним традиціям або змінам у суспільному житті); прогностичні (наявність можливості запобігання суспільно небезпечним діянням кримінально-правовими 
засобами, суспільна корисність та кримінально-політична адекватність криміналізації (співрозмірність позитивних i негативних наслідків кримінально-правової заборони), наявність ресурсів для здійснення кримінального переслідування осіб, які вчинили суспільно небезпечні діяння); техніко-юридичні (системно-правова несуперечливість, чіткість і ясність мови, повнота й ненадмірність кримінально-правової заборони).

У результаті дослідження встановлено, що кримінально-правова заборона хуліганських дій на рівні ст. 296 КК України не повною мірою є соціально обумовленою.

Щодо історичних обставин, то саме діяння «хуліганство» $є$ штучним для України 3 історичної точки зору, кримінально-правова заборона не відповідає українській ментальності, пересічні громадяни переважно не сприймають хуліганство як злочин, хуліганство не узгоджується повністю із сучасною парадигмою розвитку суспільних відносин.

Під час вивчення прогностичних обставин кримінально-правової заборони хуліганських дій дослідницьку увагу зосереджено на суспільній небезпечності цього діяння (на двох основних критеріях - об'єкт злочину та інтенсивність злочинного посягання). Доведено, що через абстрактність розуміння громадського порядку існує складність його сприйняття як об’єкта хуліганства. Стосовно інтенсивності хуліганських дій, то подібну інтенсивність (з притаманними ознаками грубого порушення, явної неповаги до суспільства, зухвалості та виняткового цинізму) мають й інші види споріднених злочинів. Тому оцінити цей показник суспільної небезпечності фактично неможливо. 3'ясовано, що кваліфікуючі ознаки хуліганства не відповідають ознакам системності та нормативної несуперечливості. За іншими елементами політичних обставин (крім наявності ресурсів) також установлюється неповна відповідність.

На підставі дослідження техніко-юридичних обставин кримінально-правової заборони хуліганських дій констатовано, що редакції ст. 296 КК України властиві неточності формулювань. Це в цілому призводить до наявності суперечностей між нормами КК України, наділяє суд та правоохоронні органи надмірними дискреційними повноваженнями.

\section{Список використаних джерел}

1. Азаров Д. С., Грищук В. К., Савченко А. В. та ін. Науково-практичний коментар Кримінального кодексу України / за заг. ред. О. М. Джужі, А. В. Савченка, В. В. Чернєя. К. : Юрінком Інтер, 2017. 1104 с.

2. Артюхова В. В. Хуліганство: кримінально-правове та кримінологічне пізнання : дис. ... канд. юрид. наук : 12.00 .08 / Інститут держави і права ім. В. М. Корецького Національної академії наук України. Київ, 2021. 301 с.

3. Балобанова Д. О. Загальні засади теорії криміналізації. Збірник наукових праць «Актуальні проблеми держави і права». 2009. № 47. С. 145-148.

4. Борисов В.И. Основные проблемы охраны безопасности производства в уголовном законодательстве Украины : автореф. дис. ... д-ра юрид. наук : 12.00 .08 / Украинская государственная юридическая академия. Х., 1993. 34 с.

5. Борисов В. И., Гизимчук С. В. Уголовная ответственность за нарушение правил, норм и стандартов, обеспечивающих безопасность дорожного движения : монография. Харьков : Консум, 2001. 160 с.

6. Дудоров О. О., Хавронюк М. І. Кримінальне право : навчальний посібник / за заг. ред. М. І. Хавронюка. Київ : Ваіте, 2014. 944 с.

7. Злобин Г. А., Келина С. Г. Некоторые теоретические вопросы криминализации общественно опасных деяний. Проблемы правосудия и уголовного права. 1978. № 1. С. 14-21.

8. Иоффе О. С., Шаргородский М. Д. Вопросы теории права. М. : Госюриздат, 1961. $381 \mathrm{c}$.

9. Івахненко О. А. Хуліганські діяння: загальне поняття та об'єкти злочинів. Часопис Київського університету права. 2015. № 1. С. 261-265. 
10. Інформаційний лист Вищого спеціалізованого суду України 3 розгляду цивільних і кримінальних справ від 30 січня 2013 р. № 223-192/0/4-13 «Про практику застосування судами при розгляді справ окремих норм матеріального права щодо кваліфікації хуліганства». URL: https://zakon.rada.gov.ua/laws/show/v0192740-13\#Text (дата звернення: 11.03.2021).

11. Книженко О. О., Іванцов В. О., Корнієць П. Ю. Актуальні питання відповідальності за вчинення хуліганства. Юрист Украӥни. 2013. № 1. С. 92-98.

12. Коломієць В. Ю. Соціальна обумовленість кримінальної відповідальності за посягання на тілесну недоторканність. Науковий вісник Дніпропетровського державного університету внутрішніх справ. 2018. № 3. С. 108-115.

13. Комарницький М. М. Кримінально-правова охорона осіб чи їх близьких родичів у зв'язку з виконанням ними свого службового чи громадського обов'язку : дис. ... канд. юрид. наук : 12.00.08 / Національна академія внутрішніх справ. К., 2017. 225 с.

14. Кришевич О.В. Міжнародно-порівняльний аспект кримінальної відповідальності за хуліганство. Кримінально-правові та кримінологічні засоби протидіі злочинам проти громадської безпеки та публічного порядку : зб. тез доп. міжнар. наук.-практ. конф. до 25-річчя ХНУВС (м. Харків, 18 квіт. 2019 р.) / МВС України, Харків. нац. ун-т внутр. справ; Кримінол. асоц. України. Харків : ХНУВС, 2019. С. 114-117.

15. Кузнєцов В. В. Сучасні фактори нормотворення у сфері кримінального права. Вісник Верховного Суду України. 2007. № 12. С. 37-40.

16. Навроцький В. О. Кримінальне право України. Особлива частина : курс лекцій. К. : Знання, 2000. 771 с.

17. Назимко Є., Коллер Ю. Використання напрацювань вчених-кримінологів під час визначення кола факторів, що обумовлюють встановлення адміністративної відповідальності за порушення у сфері безпеки дорожнього руху. Підприємництво, господарство і право. 2010. № 8. С. 153-156.

18. Налуцишин В. В. Кримінальна відповідальність за хуліганство (ст. 296 КК України) : дис. ... канд. юрид. наук : 12.00 .08 / Київський національний університет імені Тараса Шевченка. Київ, 2007. 266 с.

19. Осадчий В.І. Кримінально-правовий захист правоохоронної діяльності : монографія К. : Атіка, 2004. 336 с.

20. Пащенко О. О. Кримінальна відповідальність за порушення правил ядерної або радіаційної безпеки : дис. ... канд. юрид. наук : 12.00 .08 / Національна юридична академія України імені Ярослава Мудрого. Харків, 2004. 220 с.

21. Пащенко О. О. Соціальна обумовленість кримінально-правових норм : дис. ... дра юрид. наук : 12.00.08. / Національний юридичний університет імені Ярослава Мудрого, Міністерство освіти і науки України. Одеський державний університет внутрішніх справ, Міністерство внутрішніх справ України. Харків, Одеса, 2019. 446 с.

22. Піщенко Г. I. Попередження хуліганства (кримінально-правовий і кримінологічний аспекти) : автореф. дис. ... канд. юрид. наук : 12.00.08 / Національна академія внутрішніх справ України. К., 1999. 219 с.

23. Про судову практику у справах про хуліганство : постанова Пленуму $\begin{array}{lllll}\text { Верховного Суду України від } & 22.12 .2006 \text { p. № 10. } & \text { URL: }\end{array}$ https://zakon.rada.gov.ua/laws/show/en/va010700-06 (дата звернення: 02.03.2021).

24. Пудовкин Ю. Е. Учение об основах уголовного права : лекции. М. : Юрлитинформ, 2012. 240 с.

25. Столяр Т. В. Криміналізація умисного вбивства та умисного заподіяння тяжкого тілесного ушкодження в разі перевищення меж необхідної оборони. Науковий вісник Національної академії внутрішніх справ. 2016. № 1. С. 221-233.

26. Тадика Є. Д. Щодо декриміналізації хуліганства в Україні. Молодий вчений. 2019. № 4. C. 157-160. 
27. Федулова I. М. Соціальна обумовленість встановлення кримінальної відповідальності за протиправне заволодіння майном підприємства, установи, організації. Науковий вісник Херсонського державного університету. Серія: Юридичні науки. 2016. Вип. 3 (2). С. 88-91.

28. Шаблистий В. В., Галемін О. А. Кримінальна відповідальність за хуліганство, пов'язане 3 опором особам, наділеним владними повноваженнями під час виконання службових обов'язків чи іншим громадянам, що припиняли хуліганські дії : монографія / за заг. ред. д.ю.н., доц. В. В. Шаблистого. Дніпро : Дніпроп. держ. ун-т внутр. справ. Ліра ЛТД, 2017. $164 \mathrm{c}$.

\section{References}

1. Azarov, D. S., Hryshchuk, V. K., Savchenko, A. V. ta in (2017). Naukovopraktychnyi komentar Kryminalnoho kodeksu Ukrainy [Scientific and practical commentary of the Criminal Code of Ukraine] / za zah. red. O. M. Dzhuzhi, A. V. Savchenka, V. V. Chernieia. K. : Yurinkom Inter. 1104 s. [in Ukrainian].

2. Artiukhova, V. V. (2021). Khulihanstvo: kryminalno-pravove ta kryminolohichne piznannia [Hooliganism: Criminal and Legal and Criminological Cognition] : dys. ... kand. yuryd. nauk : 12.00.08 / Instytut derzhavy i prava im. V. M. Koretskoho Natsionalnoi akademii nauk Ukrainy. Kyiv. 301 s. [in Ukrainian].

3. Balobanova, D. O. (2009). Zahalni zasady teorii kryminalizatsii [General principles of the theory of criminalization]. Zbirnyk naukovykh prats «Aktualni problemy derzhavy i prava». № 47. S. 145-148 [in Ukrainian].

4. Borisov, V. I. (1993). Osnovnye problemy ohrany bezopasnosti proizvodstva v ugolovnom zakonodatel'stve Ukrainy [The main problems of production security in the criminal legislation of Ukraine] : avtoref. dis. ... d-ra yurid. nauk : 12.00.08 / Ukrainskaya gosudarstvennaya yuridicheskaya akademiya X. 34 s. [in Russian].

5. Borisov, V. I., Gizimchuk, S. V. (2001). Ugolovnaya otvetstvennost' za narushenie pravil, norm i standartov, obespechivayushchih bezopasnost' dorozhnogo dvizheniya [Criminal liability for violation of rules, norms and standards ensuring road safety] : monografiya. Har'kov : Konsum. 160 s. [in Russian].

6. Dudorov, O. O., Khavroniuk, M. I. (2014). Kryminalne pravo [Criminal Law] : navchalnyi posibnyk / za zah. red. M. I. Khavroniuka. Kyiv : Vaite. 944 s. [in Ukrainian].

7. Zlobin, G. A., Kelina, S. G. (1978). Nekotorye teoreticheskie voprosy kriminalizacii obshchestvenno opasnyh deyanij [Some theoretical issues of criminalization of socially dangerous acts]. Problemy pravosudiya i ugolovnogo prava. № 1. S. 14-21 [in Russian].

8. Ioffe, O. S., SHargorodskij, M. D. (1961). Voprosy teorii prava [Questions of law theory]. M. : Gosyurizdat. 381 s. [in Russian].

9. Ivakhnenko, O. A. (2015). Khulihanski diiannia: zahalne poniattia ta obiekty zlochyniv [Hooligan acts: general concept and crime objects]. Chasopys Kyivskoho universytetu prava. № 1. S. 261-265 [in Ukrainian].

10. Informatsiinyi lyst Vyshchoho spetsializovanoho sudu Ukrainy $\mathrm{z}$ rozghliadu tsyvilnykh i kryminalnykh sprav vid 30 sichnia 2013 r. № 223-192/0/4-13 «Pro praktyku zastosuvannia sudamy pry rozghliadi sprav okremykh norm materialnoho prava shchodo kvalifikatsii khulihanstva» [Information Letter of the High Specialized Court of Ukraine for the consideration of civil and criminal cases of January 30, 2013 No. 223-192/0/4-13 «On the practice of applying courts when considering cases of material law relative to the qualifications of hooliganism»]. URL: https://zakon.rada.gov.ua/laws/show/v0192740-13\#Text (data zvernennia: 11.03.2021) [in Ukrainian].

11. Knyzhenko, O. O., Ivantsov, V. O., Korniiets, P. Iu. (2013). Aktualni pytannia vidpovidalnosti za vchynennia khulihanstva [Actual questions of responsibility for the commission of hooliganism]. Yuryst Ukrainy. № 1. S. 92-98 [in Ukrainian]. 
12. Kolomiiets, V. Yu. (2018). Sotsialna obumovlenist kryminalnoi vidpovidalnosti za posiahannia na tilesnu nedotorkannist [Social conditionality of criminal liability for encroachment on bodily inviolability]. Naukovyi visnyk Dnipropetrovskoho derzhavnoho universytetu vnutrishnikh sprav. № 3. S. 108-115 [in Ukrainian].

13. Komarnytskyi, M. M. (2017). Kryminalno-pravova okhorona osib chy yikh blyzkykh rodychiv u zviazku z vykonanniam nymy svoho sluzhbovoho chy hromadskoho oboviazku [Criminal legal protection of persons or their close relatives in connection with their performance or public duty] : dys. ... kand. yuryd. nauk : 12.00.08 / Natsionalna akademiia vnutrishnikh sprav. K. 225 s. [in Ukrainian].

14. Kryshevych, O. V. (2019). Mizhnarodno-porivnialnyi aspekt kryminalnoi vidpovidalnosti za khulihanstvo [International-comparative aspect of criminal liability for hooliganism]. Kryminalno-pravovi ta kryminolohichni zasoby protydii zlochynam proty hromadskoi bezpeky ta publichnoho poriadku : zb. tez dop. mizhnar. nauk.-prakt. konf. do 25-richchia KhNUVS (m. Kharkiv, 18 kvit. 2019 r.) / MVS Ukrainy, Kharkiv. nats. un-t vnutr. sprav; Kryminol. asots. Ukrainy. Kharkiv : KhNUVS. S. 114-117 [in Ukrainian].

15. Kuznietsov, V. V. (2007). Suchasni faktory normotvorennia u sferi kryminalnoho prava [Modern factors of normoging in the field of criminal law]. Visnyk Verkhovnoho Sudu Ukrainy. № 12. S. 37-40 [in Ukrainian].

16. Navrotskyi, V. O. (2000). Kryminalne pravo Ukrainy [Criminal Law of Ukraine]. Osoblyva chastyna : kurs lektsii. K. : Znannia. 771 s. [in Ukrainian].

17. Nazymko, Ye., Koller, Yu. (2010). Vykorystannia napratsiuvan vchenykhkryminolohiv pid chas vyznachennia kola faktoriv, shcho obumovliuiut vstanovlennia administratyvnoi vidpovidalnosti za porushennia u sferi bezpeky dorozhnoho rukhu [Use of developments of scientists-criminologists when determining the circle of factors that determine the establishment of administrative responsibility for violations in the field of road safety]. Pidpryiemnytstvo, hospodarstvo i pravo. № 8. S. 153-156 [in Ukrainian].

18. Nalutsyshyn, V. V. (2007). Kryminalna vidpovidalnist za khulihanstvo (st. 296 KK Ukrainy) [Criminal liability for hooliganism (Article 296 of the Criminal Code of Ukraine)] : dys. ... kand. yuryd. nauk : 12.00.08 / Kyivskyi natsionalnyi universytet imeni Tarasa Shevchenka. Kyiv. 266 s. [in Ukrainian].

19. Osadchyi, V. I. (2004). Kryminalno-pravovyi zakhyst pravookhoronnoi diialnosti [Criminal defense of law enforcement] : monohrafiia K. : Atika. 336 s. [in Ukrainian].

20. Pashchenko, O. O. (2004). Kryminalna vidpovidalnist za porushennia pravyl yadernoi abo radiatsiinoi bezpeky [Criminal liability for violation of nuclear or radiation safety rules] : dys. ... kand. yuryd. nauk : 12.00.08 / Natsionalna yurydychna akademiia Ukrainy imeni Yaroslava Mudroho. Kharkiv. 220 s. [in Ukrainian].

21. Pashchenko, O. O. (2019). Sotsialna obumovlenist kryminalno-pravovykh norm [Social conditionality of criminal-law norms] : dys. ... d-ra yuryd. nauk : 12.00.08. / Natsionalnyi yurydychnyi universytet imeni Yaroslava Mudroho, Ministerstvo osvity i nauky Ukrainy. Odeskyi derzhavnyi universytet vnutrishnikh sprav, Ministerstvo vnutrishnikh sprav Ukrainy. Kharkiv, Odesa. 446 s. [in Ukrainian].

22. Pishchenko, H. I. (1999). Poperedzhennia khulihanstva (kryminalno-pravovyi i kryminolohichnyi aspekty) [Warning of hooliganism (criminal legal and criminological aspects)] : avtoref. dys. ... kand. yuryd. nauk : 12.00 .08 / Natsionalna akademiia vnutrishnikh sprav Ukrainy. K. 219 s. [in Ukrainian].

23. Pro sudovu praktyku u spravakh pro khulihanstvo : postanova Plenumu Verkhovnoho Sudu Ukrainy vid 22. 12. 2006 r. № 10. [On judicial practice in cases of hooliganism: a decision of the Plenum of the Supreme Court of Ukraine of 22.12.2006 № 10]. URL: https://zakon.rada.gov.ua/laws/show/en/va010700-06 (data zvernennia: 02.03.2021) [in Ukrainian].

24. Pudovkin, YU. E. (2012). Uchenie ob osnovah ugolovnogo prava [Treachers in the basics of the main law] : lekcii. M. : YUrlitinform. 240 s. [in Russian]. 
25. Stoliar, T. V. (2016). Kryminalizatsiia umysnoho vbyvstva ta umysnoho zapodiiannia tiazhkoho tilesnoho ushkodzhennia $\mathrm{v}$ razi perevyshchennia mezh neobkhidnoi oborony [Criminalization of intentional murder and deliberate infliction of severe bodily injury in case of exceeding the boundaries of the required defense]. Naukovyi visnyk Natsionalnoi akademii vnutrishnikh sprav. № 1. S. 221-233 [in Ukrainian].

26. Tadyka, Ye. D. (2019). Shchodo dekryminalizatsii khulihanstva v Ukraini [Regarding decriminalization of hooliganism in Ukraine]. Molodyi vchenyi. № 4. S. 157-160 [in Ukrainian].

27. Fedulova, I. M. (2016). Sotsialna obumovlenist vstanovlennia kryminalnoi vidpovidalnosti za protypravne zavolodinnia mainom pidpryiemstva, ustanovy, orhanizatsii [Social condition for the establishment of criminal liability for unlawful possession of the property of the enterprise, institution, organization]. Naukovyi visnyk Khersonskoho derzhavnoho universytetu. Seriia : Yurydychni nauky. Vyp. 3 (2). S. 88-91 [in Ukrainian].

28. Shablystyi, V. V., Halemin, O. A. (2017). Kryminalna vidpovidalnist za khulihanstvo, poviazane $\mathrm{z}$ oporom osobam, nadilenym vladnymy povnovazhenniamy pid chas vykonannia sluzhbovykh oboviazkiv chy inshym hromadianam, shcho prypynialy khulihanski dii [Criminal liability for hooliganism associated with resistance to persons endowed with power powers while performing official duties or other citizens who stopped hooligan actions] : monohrafiia / za zah. red. d.iu.n., dots. V. V. Shablystoho. Dnipro: Dniprop. derzh. un-t vnutr. sprav. Lira LTD. 164 s. [in Ukrainian].

\author{
Nazymko Yehor, \\ Doctor of Law, Senior Research Fellow \\ (Donetsk State University of Internal Affairs, Mariupol) \\ ORCID: https://orcid.org/0000-0003-4949-4155
}

\author{
Demchyshyn Dmytro, \\ Lecturer \\ (Donetsk State University of Internal Affairs, Mariupol) \\ ORCID: https://orcid.org/0000-0002-4172-1272
}

\title{
SOCIAL CONDITIONALITY OF THE CRIMINAL-LEGAL PROHIBITION OF HOOLIGAN ACTIONS
}

The article examines the social conditionality of the criminal-legal prohibition of hooligan actions. The expediency of analyzing the social conditionality of the criminal-legal prohibition of hooligan actions as a cross-cutting criminal legal category is substantiated, taking into account the systemic connections between all elements of crimes, a constructive feature of which is hooliganism. Taking into account the peculiarities of the appointment of normative prescriptions of the Criminal Code of Ukraine, prohibiting hooligan actions in the system of criminal law regulation, a system of circumstances of social conditionality of the criminal law prohibition of hooligan actions has been determined: historical; predictive; technical and legal. As a result of the study, it was established that the criminal-legal prohibition of hooligan actions at the level of the existence of Art. 296 of the Criminal Code of Ukraine, fully socially conditioned. With regard to historical circumstances, the same act of «hooliganism» is artificial for Ukraine from a historical point of view, the criminal law prohibition does not correspond to the Ukrainian mentality, ordinary citizens in most cases do not perceive hooliganism as a crime, hooliganism does not fully fit into the modern paradigm of the development of social relationship. During the study of the prognostic circumstances of the criminal law prohibition of hooligan actions, research attention is focused on the social danger of this act (two main criteria are the object of the crime and the intensity of the criminal encroachment). It has been proved that through the abstractness of understanding social order, there is a difficulty in its perception as an object of hooliganism. With regard to the intensity of hooligan actions, other types of related crimes have a similar intensity (with inherent signs of gross violation, obvious disrespect 
for society, insolence and exceptional cynicism). Therefore, it is virtually impossible to assess this indicator of public danger. It is proved that the qualifying signs of hooliganism do not correspond to the signs of consistency and normative consistency. For other elements of political circumstances (except for the availability of resources), it is also established in full compliance. Based on the study of the technical and legal circumstances of the criminal-legal prohibition of hooligan actions, it was stated that the wording of Art. 296 of the Criminal Code of Ukraine inherent inaccuracies in wording. This, in general, leads to the existence of a contradiction between the norms of the Criminal Code of Ukraine, endows the court and law enforcement agencies with excessive discretionary powers.

Key words: social conditioning; criminal law prohibition; hooliganism; cross-cutting category; circumstance; value concept.

Надіслано до редколегії 29.03.2021

Рекомендовано до публікації 05.04.2021 


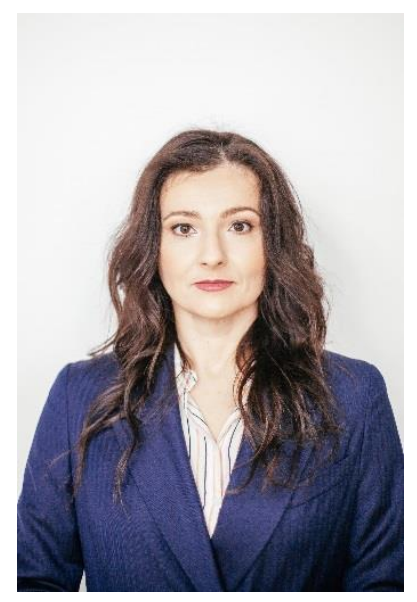

\section{Пересада Ольга Михайлівна,} кандидат юридичних наук, доцент (Донеиький державний університет внутрішніх справ, м. Маріуполь) ORCID: https://orcid.org/0000-0001-7199-1938

\section{ВІДМЕЖУВАННЯ УМИСНОГО ВБИВСТВА ВІД САМОГУБСТВА ТА НЕЩАСНОГО ВИПАДКУ: ТЕОРЕТИКО-МЕТОДОЛОГІЧНІ ПІДХОДИ}

У статті розглянуто актуальні питання визначення та кваліфікації умисного вбивства. Зазначено, щуо умисне вбивство слід відмежовувати від суміжних $і$ схожих за зовнішніми проявами таких подій, як самогубство та нещасний випадок. Автором виявлено низку спільних та відмінних ознак, які слід враховувати правоохоронним органам під час кваліфікачії події, щзо передбачає насильницьку смерть людини. Також проаналізовано окремі риси об 'єкта, суб'єкта, об 'єктивної та суб 'єктивної сторони умисного вбивства, які будуть ключовими під час вирішення питання кваліфікації. 3'ясовано певні ознаки нещасного випадку, за якими така подія відрізняється від умисного вбивства.

Ключові слова: життя; кримінальне право; кваліфікація; умисне вбивство; самогубство; склад кримінального правопорушення.

Постановка проблеми. Кваліфікація умисних вбивств у сучасних умовах розвитку кримінального законодавства спричиняє низку проблемних теоретико-методологічних $\mathrm{i}$ практично-прикладних питань. Зокрема, йдеться про проблеми розмежування вбивства, самогубства та нещасного випадку як суміжних понять у теорії та практиці сучасного кримінального права.

До того ж дослідження теоретико-методологічних засад визначення та юридичної кваліфікації умисних вбивств 3 точки зору їх розмежування 3 самогубством та нещасним випадком становить досить важливу наукову та практичну проблему сучасного кримінального права. Умисні вбивства можуть бути схожими на скоєння самогубства чи нещасний випадок або, навпаки, вказані події можуть за об'єктивною стороною нагадувати умисне вбивство, але відрізнятися за іншими елементами складу злочину, такими як об'єкт, суб'єкт та суб'єктивна сторона, що потребує встановлення теоретико-методологічних засад визначення наявності чи відсутності кожного з елементів складу злочину під час розгляду конкретного факту заподіяння людині насильницької смерті.

Аналіз останніх досліджень і публікацій. Слід зазначити, що проблематика визначення та кваліфікації умисних вбивств досить детально розглядається у вітчизняній юридичній літературі. Варто звернути увагу на праці С. В. Албула, Ю. В. Бауліна, С. В. Бородіна, О. П. Бугайчук, О. М. Костенка, Д. І. Лопащука, О. С. Сотули, А. В. Холостенко, О. М. Храмцова та інших дослідників. Водночас удосконалення потребують наявні теоретико-методологічні підходи до відмежування умисних вбивств від таких суміжних понять, як самогубство та нещасний випадок 3 урахуванням сучасних 
кримінально-правових доктринальних позицій та правозастосовної практики.

Мета цієї статті - розробити науково обгрунтовані теоретико-методологічні підходи до відмежування умисних убивств від самогубств та нещасних випадків, на підставі яких надати пропозиції щодо визначення критеріїв кваліфікації відповідних діянь.

Виклад основного матеріалу. Розглядаючи теоретико-методологічні засади визначення та класифікації злочинів проти життя в сучасному кримінальному праві, слід зазначити, що найтяжчим злочином проти життя особи в українській кримінально-правовій нормативній системі визнається вбивство, оскільки саме в цьому разі життя є безпосереднім об'єктом злочинного посягання, причому йдеться лише про життя іншої людини, адже скоєння самогубства не визнається злочином, а оцінка такого діяння має тільки морально-етичний характер.

Важливість правильної кваліфікації діяння полягає у необхідності притягнення винного (у разі його наявності) до відповідальності, яка передбачена законодавством України. Адже випадки, коли перед слідством постає проблема визначити, чи особа вчинила самогубство, чи було скоєне умисне вбивство, часто зустрічаються на практиці. Наприклад, у липні 2016 року у військовій частині поблизу Авдіївки помер військовослужбовець. Офіційно подія була кваліфікована як самогубство, проте родичі та знайомі загиблого категорично заперечують відповідну версію, вказуючи на те, що певні обставини смерті свідчать про інше [1]. У жовтні 2017 року поблизу Києва виявили тіло чоловіка з вогнепальним пораненням грудної клітки. Огляд місця події давав підстави вважати це самогубством, проте велика кількість інших доказів указувала на ймовірність факту умисного вбивства [2]. Цілком можливо, обстановка, яка означала, що особа самостійно вкоротила собі віку, була свідомо імітована. У слідчій практиці $\epsilon$ немало прикладів таких спроб зловмисника уникнути розслідування вбивства, а отже і загрози кримінального переслідування та покарання. Восени 2020 року біля Станиці Луганської один військовослужбовець убив іншого, а злочин хотів приховати, тому інсценував самогубство жертви [3].

Вирішуючи питання про кваліфікацію юридичного факту як умисного вбивства або самогубства, необхідно зважати на наявність чи відсутність елементів складу умисного вбивства як злочину, до яких належать об'єкт, об'єктивна сторона, суб'єкт та суб'єктивна сторона.

Безпосереднім об’єктом убивства є життя іншої людини незалежно від ії віку, статі, громадянства, національності, соціального стану та будь-яких інших індивідуальних чи колективних (групових) ознак. До того ж під «іншою людиною», яка має право на життя, що охороняється кримінально-правовим законодавством, у вітчизняній юридичній доктрині вважається фізична особа на всіх етапах іiї біологічного розвитку та існування: від початку фізіологічних пологів (у тому числі передчасних чи штучних) до біологічної смерті людини, під якою слід розуміти такий стан організму людини, коли зупиняється робота серця, унаслідок чого відбувається безповоротний процес розпаду клітин центральної нервової системи (при цьому слід пам'ятати, що «в умовах зупинки роботи серця і дихання можливе збереження життєдіяльності людського організму і людину за певних зусиль можна врятувати від смерті. Тому теоретично є можливим заподіяння біологічної смерті (вбивства) людини, яка знаходиться у стані клінічної смерті») [4, с. 36].

Водночас насильницький характер смерті є лише однією 3 ознак убивства, але притаманний також самогубству та нещасному випадку, які можна цілком справедливо віднести до суміжних юридичних фактів, за зовнішніми ознаками схожими на факт скоєння умисного вбивства, що потребує відповідної правильної кваліфікації та кримінально-правової оцінки.

За твердженням С. В. Бородіна, «спільним у скоєнні вбивства та самогубства є об'єкт посягання - життя людини, але під час учинення самогубства об'єкт та суб'єкт діяння співпадають» [5, с. 19]. 3 огляду на подібну методологічну конструкцію факт самогубства не призводить до будь-яких кримінально-правових наслідків для особи, яка залишилася живою внаслідок невдалої спроби скоєння означеної дії. 
На відміну від убивства, яке може бути як умисним, так і необережним, самогубство є тільки умисним та має додаткову обов'язкову ознаку - мету позбавити себе життя. У цьому разі індиферентне психічне ставлення особи у вигляді непрямого умислу, коли особа передбачає результат своїх дій та байдуже ставиться до їх можливих наслідків, виключає кваліфікацію такого юридичного факту, як самогубство. На наш погляд, такі дії можна визначити як надмірний ризик, на який умисно йде особа, але при цьому завжди зберігає певний ступінь внутрішньої надії залишитися живою. Водночас випадок, коли особа цілком розуміє невідворотність своєї загибелі внаслідок скоєння конкретної власної дії, можна справедливо вважати самогубством, тобто умисним позбавленням себе біологічного життя.

Особливість нормативно-правового регулювання самогубства полягає в тому, що зазначене поняття відсутне в чинному кримінальному законодавстві, крім юридичної конструкції «доведення до самогубства» як самостійного складу злочину проти життя людини, передбаченого ст. 120 Кримінального кодексу України (далі - КК України) [6], який розуміється як «доведення особи до самогубства або до замаху на самогубство, що $є$ наслідком жорстокого з нею поводження, шантажу, систематичного приниження ії̈ людської гідності або систематичного протиправного примусу до дій, що суперечать іiі волі, схиляння до самогубства, а також інших дій, що сприяють вчиненню самогубства», але у цій статті жодним чином не розкриваються ознаки чи способи скоєння власне самогубства, натомість ідеться тільки про протиправні дії винної особи, що призвели до скоєння самогубства іншою людиною.

Поняття «самогубство» можна знайти лише в деяких підзаконних актах, насамперед внутрішнього (відомчого) характеру. Так, у Правилах внутрішнього розпорядку в ізоляторах тимчасового тримання органів внутрішніх справ України самогубство згадується як особлива несприятлива обставина, що є підставою для скорочення часу прогулянки затриманих. Крім цього, указано, що працівники ізоляторів зобов'язані надавати медичну допомогу особам під час спроб самогубства [7].

До того ж Порядок та умови виплати одноразової грошової допомоги у разі загибелі (смерті), травми або поранення, захворювання чи інвалідності осіб рядового і начальницького складу служби цивільного захисту встановлює, що така допомога не виплачується, якщо смерть чи каліцтво настало внаслідок самогубства чи замаху на самогубство. Винятком $\epsilon$ ситуація, коли такі дії зумовлені хворобою чи особу довели до самогубства [8].

Серед наукових джерел, присвячених проблемі визначення поняття та ознак самогубства, слід окремо звернути увагу на праці В. Д. Воднік. Як слушно зауважує автор, «самогубство - це явище соціальної патології, умисні та свідомі дії, спрямовані на позбавлення себе життя» [9, с. 142].

Отже, самогубство має декілька основних ознак за умовною аналогією зі складами злочинів, передбаченими Особливою частиною чинного Кримінального кодексу України, що дозволяє розмежувати відповідно до таких ознак умисне вбивство та самогубство.

По-перше, суб'єктний склад самогубства завжди обмежений однією особою, тоді як умисне вбивство може мати й індивідуальний, і колективний (груповий) склад суб'єктів за його кількісним виміром.

По-друге, за суб'єктивною стороною учасник події самогубства усвідомлено бажає настання наслідку (своєї смерті), для чого вчиняє відповідні дії, тоді як умисел особи суб'єкта умисного вбивства - завжди спрямований на позбавлення життя іншої особи потерпілого. До того ж як самогубець, так і вбивця не намагаються запобігти наслідкам, а, навпаки, прискорюють їх настання, адже чітко усвідомлюють основний наслідок і розуміють значення та кінцевий результат своїх дій, що є спільною ознакою психічного ставлення особи до вчиненого діяння у двох випадках, розмежування яких розглядається. Також надзвичайно важливою складовою суб'єктивної сторони в цьому разі є мотив. Установлення мотиву вбивства $\epsilon$ обов'язковим, адже це елемент складу злочину. У разі самогубства визначення мотиву теж убачається необхідним, бо об'єктивно людина не може без причини прийняти рішення позбавити себе життя. Відсутність такої причини може розглядатися як підстава 
сумніватися у кваліфікації діяння як самогубства, проте лише в комплексі 3 іншими обставинами. Варто зазначити, що сама по собі незрозумілість причин самогубства не може бути підставою розглядати подію як умисне вбивство.

По-третє, за об’єктом самогубство з прямим умислом посягає на власне життя, а умисне вбивство - на життя іншої людини, що є основним критерієм відмежування цих двох юридичних фактів з метою їхньої правильної кримінально-правової кваліфікації.

Щодо об’єктивної сторони, то умисне вбивство та самогубство можуть мати дуже схожі характеристики. Наприклад, за об'єктивною стороною й умисне вбивство, і самогубство можуть вчинятися як через дію, так і через бездіяльність (в останньому випадку можна навести приклади свідомого ненадання допомоги зобов'язаною особою, якщо прямим умислом $\epsilon$ позбавлення життя іншої людини, i, навпаки, невиконання певних медичних рекомендацій самогубцем, якщо свідомим та невідворотним наслідком цього є власна біологічна смерть). Отже, аналіз цього елемента варто розглядати як допоміжний критерій відмежування умисного вбивства від самогубства.

Іншим суміжним 3 умисним вбивством поняттям, що безпосередньо впливає на складність кримінально-правової кваліфікації, є така подія, як нещасний випадок.

На відміну від умисного вбивства, у разі нещасного випадку не враховується суб'єктивна сторона у вигляді вини особи, тобто йдеться про випадковий збіг обставин, що призвів до трагічної події - насильницької смерті.

Нещасний випадок - це тілесні пошкодження або смерть, інколи пошкодження майна, причиною яких $\epsilon$ несподіваний збіг обставин. У цьому разі зазвичай мається на увазі, що негативного ймовірного результату можливо було уникнути або запобігти, якщо причини, що призвели до нещасного випадку, були б розпізнані раніше.

Типовими прикладами виробничих та невиробничих нещасних випадків у наявній слідчій та судовій практиці є автомобільна катастрофа, падіння 3 висоти, потрапляння предметів у дихальне горло, падіння предметів (цеглини, бурульки) на голову, ураження електричним струмом. Чинниками ризику можуть бути: недотримання техніки безпеки, вживання алкоголю, наркотичних засобів, внутрішній стан хвилювання, наявність хронічних захворювань (наприклад епілепсія) тощо.

Окремим видом нещасного випадку є заподіяння смерті самому собі внаслідок власної недбалості як на виробництві, так і в побутових умовах, що також виключає кримінальноправову оцінку за об'єктивною (зовнішньою) стороною випадкової трагічної події.

Нормативно-правове визначення нещасного випадку в чинному кримінальному законодавстві України відсутнє і знаходиться лише у сфері підзаконних актів адміністративноправового характеру. На підставі аналізу цих актів нещасні випадки можна умовно поділити на нещасні випадки виробничого та невиробничого характеру.

Достатньо розгорнуте визначення нещасного випадку виробничого характеру наведено в Порядку проведення розслідування та ведення обліку нещасних випадків, професійних захворювань та аварій на виробництві [11]. Згідно $з$ пунктом 7 цього Порядку розслідування проводиться у разі виникнення нещасного випадку, а саме обмеженої в часі події або раптового впливу на працівника небезпечного виробничого фактора або середовища, що сталися у процесі виконання ним трудових обов'язків, внаслідок яких зафіксовано шкоду здоров'ю, зокрема від одержання поранення, травми, у тому числі внаслідок тілесних ушкоджень, гострого професійного захворювання (отруєння) та інших отруєнь, одержання сонячного або теплового удару, опіку, обмороження, а також у разі утоплення, ураження електричним струмом, блискавкою та іонізуючим випромінюванням, одержання інших ушкоджень унаслідок аварії, пожежі, стихійного лиха (землетрусу, зсуву, повені, урагану тощо), контакту з представниками тваринного і рослинного світу, які призвели до втрати працівником працездатності на один робочий день чи більше або до необхідності переведення його на іншу (легшу) роботу не менш як на один робочий день, зникнення, а також настання смерті працівника під час виконання ним трудових (посадових) обов’язків. 
Для порівняння слід також навести визначення нещасного випадку, що міститься в Порядку розслідування та обліку нещасних випадків невиробничого характеру. Згідно з цим документом нещасні випадки невиробничого характеру слід розуміти як не пов'язані 3 виконанням трудових обов'язків травми, у тому числі отримані внаслідок заподіяних тілесних ушкоджень іншою особою, отруєння, самогубства, опіки, обмороження, утоплення, ураження електричним струмом, блискавкою, травми, отримані внаслідок стихійного лиха, контакту 3 тваринами тощо, які призвели до ушкодження здоров'я або смерті потерпілих [12].

Таке визначення є більш відповідним для узагальненого використання у сфері кримінального права, проте містить певні недоліки, зокрема намагання віднести травми, отримані під час скоєння самогубства, до категорії нещасних випадків, 3 чим важко погодитися, адже у цьому разі йдеться саме про замах на самогубство, а не про нещасний випадок, що має вирішальне значення, зокрема для кримінально-правової кваліфікації діяння за ст. 120 КК України як доведення до самогубства, у якій кримінально караним $є$ доведення до самогубства чи до замаху на самогубство, а не про нещасний випадок. Тобто практичне значення може мати не тільки відмежування умисного вбивства від нещасного випадку та самогубства, а й правильне розмежування самогубства та нещасного випадку між собою, що впливає і на правильну кримінально-правову кваліфікацію такого самостійного складу злочину, як доведення до самогубства.

Також варто зазначити, що хоча настання насильницької смерті особи є наслідком відповідних подій, проте в них немає складу кримінального правопорушення. Здебільшого йдеться про відсутність зв'язку між діями (бездіяльністю суб'єкта) та настанням негативних наслідків або ситуацію, у якій суб'єкт та постраждалий є тією самою особою. Остання ситуація відрізняється від самогубства відсутністю умислу щодо настання смерті.

Від умисного вбивства нещасний випадок відрізняється за такими основними ознаками. По-перше, учасники події, що трактується як нещасний випадок, не бажають настання його наслідків, при цьому постраждала особа намагається уникнути наслідків цього випадку, рятуючи себе та інших осіб, однак нещасний випадок відбувається проти волі особи. По-друге, умисне вбивство завжди за суб'єктивною стороною має форму умислу винної особи, а нещасний випадок завжди передбачає відсутність умислу як психічного ставлення особи до скоєної дії чи бездіяльності.

У разі наявності причинно-наслідкового зв'язку між діями особи та негативними наслідками, а також за умови, що винний у заподіянні насильницької смерті іншій людині не мав жодного наміру спричинити смерть і навіть не усвідомлював таку теоретичну можливість, не може йтися про умисне вбивство. Таку подію варто кваліфікувати як убивство через необережність, а у разі, якщо ій передувало порушення спеціальним суб'єктом правил та норм на виробництві, - за відповідною статтею розділу 10 Кримінального кодексу України.

Висновки. Отже, для остаточної та правильної кваліфікації події, у результаті якої настала насильницька смерть особи, як умисного вбивства необхідно детально з'ясувати всі обставини, що становлять склад відповідного злочину.

Об' єктом посягання умисного вбивства завжди є життя іншої людини, тоді як об'єктом посягання самогубства буде власне життя. Суб'єктно-об'єктний склад події нещасного випадку має винятково випадковий характер унаслідок збігу фактичних обставин, може частково співпадати або не співпадати з відповідними кваліфікаційними ознаками умисного вбивства.

Щодо об'єктивної сторони, то обставини умисного вбивства, самогубства та нещасного випадку можуть бути схожими та мати багато спільного. Проте істотним буде встановлення причинного зв'язку між діянням та наслідками. Якщо цей зв'язок відсутній, то можна стверджувати, що стався нещасний випадок. Якщо ж причинний зв'язок наявний, то особливої уваги заслуговує суб'єктивна сторона події, а саме наявність та форма вини особи. Умисне вбивство завжди характеризується умислом на позбавлення особи життя. Якщо ж винна особа не мала відповідного наміру та навіть не усвідомлювала можливості настання таких наслідків, 
діяння варто кваліфікувати за іншими статтями Кримінального кодексу України залежно від інших обставин (наприклад, ст. 119 «Вбивство через необережність» тощо).

Що ж стосується суб’єкта, то варто зазначити таке: якщо суб'єкт діяння та постраждала особа співпадають (у разі самогубства або заподіяння з необережності смерті самому собі), кваліфікацію діяння як умисного вбивства можна виключити.

\section{Список використаних джерел}

1. Вбивство чи самогубство? Досудова тяганина тривалістю в роки. Радіо Свобода. URL: https://www.radiosvoboda.org/a/29257895.html (дата звернення: 05.04.2021).

2. Вбивство чи самогубство? У Києві виявили тіло молодого чоловіка 3 простреленими грудьми. URL: https://www.facebook.com/watch/?v=2001891700022695 (дата звернення: 05.04.2021).

3. Вбивство 21-річного бійця на Луганщині спробували замаскувати під самогубство. URL: https://zaxid.net/na_luganshhini_vbivstvo_21_richnogo_viyskovogo_namagalis_zamaskuvati_pid_ samogubstvo_n1510648 (дата звернення: 05.04.2021).

4. Науково-практичний коментар до Кримінального кодексу України : у 2 ч. / під заг. ред. М. О. Потебенька, В. Г. Гончаренка. К. : Форум, 2001. Ч. 2 : Особлива частина. 944 с.

5. Бородин С. В. Квалификация преступлений против жизни. М. : Юридическая литература, 1977. 240 с.

6. Кримінальний кодекс України від 05 квітня 2001 р. Відомості Верховної Ради України. 2001. № 25-26. Ст. 131.

7. Про затвердження Правил внутрішнього розпорядку в ізоляторах тимчасового тримання органів внутрішніх справ України : наказ Міністерства внутрішніх справ України № 638 від 02 грудня 2008 p. URL: https://zakon.rada.gov.ua/laws/show/z0137-09 (дата звернення: 05.04.2021).

8. Про затвердження Порядку та умов виплати одноразової грошової допомоги у разі загибелі (смерті), травми або поранення, захворювання чи інвалідності осіб рядового i начальницького складу служби цивільного захисту : Постанова Кабінету Міністрів України № 908 від 11 липня 2007 p. URL: https://zakon.rada.gov.ua/laws/show/908-2007-\%D0\%BF\#Text (дата звернення: 05.04.2021).

9. Воднік В. Д. Самогубство: причини та шляхи профілактики. Вісник Наџіонального університету «Юридична академія України імені Ярослава Мудрого». Серія: «Філософія, філософія права, політологія, соціологія». 2013. № 3 (17). С. 140-160.

10. Про затвердження Положення про порядок розслідування нещасних випадків, що сталися із здобувачами освіти під час освітнього процесу : наказ Міністерства освіти $\mathrm{i}$ науки України від 16 травня 2019 p. URL: https://zakon.rada.gov.ua/laws/show/z0612-19\#n (дата звернення: 05.04.2021).

11. Про затвердження Порядку проведення розслідування та ведення обліку нещасних випадків, професійних захворювань і аварій на виробництві : Постанова Кабінету Міністрів України № 337 від 17 квітня 2019 p. URL: https://zakon.rada.gov.ua/laws/show/3372019-\%D0\%BF\#Text (дата звернення: 05.04.2021).

12. Про затвердження Порядку розслідування та обліку нещасних випадків невиробничого характеру : Постанова Кабінету Міністрів України № 270 від 22 березня 2001 p. URL: https://zakon.rada.gov.ua/laws/show/270-2001-\%D0\%BF\#Text (дата звернення: 05.04.2021). 


\section{References}

1. Vbivstvo chi samogubstvo? Sudova tiaganina trivalistiu v roky [Murder or suicide? Litigation lasting for years]. Radio Svoboda. URL: https://www.radiosvoboda.org/a/29257895.html (data zvernennia: 05.04.2021) [in Ukrainian].

2. Vbivstvo chi samogubstvo? U Kyevi vyavili tilo mololdogo cholovika z prostrelenimi grudmi [Murder or suicide? The body of a young man with a shot in the chest was found in Kyiv]. URL: https://www.facebook.com/watch/?v=2001891700022695 (data zvernennia: 05.04.2021) [in Ukrainian].

3. Vbivstvo 21-richnogo biytsia na Luganshini sprobuvali zamaskuvati pid samogubstvo [The murder of a 21-year-old soldier in the Luhansk region has been tried to disguise as suicide]. URL: https://zaxid.net/na_luganshhini_vbivstvo_21_richnogo_viyskovogo_namagalis_zamaskuvati_pid_ samogubstvo_n1510648 (data zvernennia: 05.04.2021) [in Ukrainian].

4. Naukovo-praktychnyi komentar do Kryminalnoho kodeksu Ukrainy : u 2 ch. [Scientific and practical commentary to the Criminal Code of Ukraine] / pid zah. red. M. O. Potebenka, V. H. Honcharenka. K. : Forum, 2001. Ch. 2 : Osoblyva chastyna. 944 s. [in Ukrainian].

5. Borodin, S. V. (1977). Kvalifikatsiya prestupleniy protiv zhizni [Qualification of crimes against life]. M. : Yuridicheskaya literatura. 240 s. [in Russian].

6. Kryminalnyi kodeks Ukrainy vid 05 kvitnia $2001 \mathrm{r}$. [The Criminal Code of Ukraine of April 05, 2001]. Vidomosti Verkhovnoi Rady Ukrainy. 2001. № 25-26. St. 131 [in Ukrainian].

7. Pro zatverdjennia Pravil vnutrishnogo rozporiadku v izoliatorach timchasovogo trimannia organiv vnutrishnikh sprav Ukraini : nakaz Ministerstva vnutrishnikh sprav Ukraini № 638 vid 02 grudnia 2008 r. [On approval of the Rules of Procedure in temporary detention facilities of the bodies of internal affairs of Ukraine : Order of the Ministry of Internal Affairs of Ukraine № 638 of December 2, 2008]. URL: https://zakon.rada.gov.ua/laws/show/z0137-09 (data zvernennia: 05.04.2021) [in Ukrainian].

8. Pro zatverdjennia Poriadku ta umov viplati odnorazovoi groshovoi dopomogi u razi zagibeli (smerti), travmi abo poranennia, zahvoriuvannia chi invalidnosti osib riadovogo i nachalnitskogo skladu sluzhbi civilnogo zahistu : Postanova Kabinetu Ministriv Ukraini № 908 vid 11 lypnia 2007 r. [On approval of the Procedure and conditions for payment of one-time financial assistance in case of death, trauma or injury, illness or disability of members of the rank and file and senior staff of the Civil Defense Service: Resolution of the Cabinet of Ministers of Ukraine № 908 of July 11, 2007]. URL: https://zakon.rada.gov.ua/laws/show/908-2007-\%D0\%BF\#Text (data zvernennia: 05.04.2021) [in Ukrainian].

9. Vodnik, V. D. (2013). Samogubstvo: prichinin ta shliakhi profilaktiki. Visnik Natsionalnogo universitetu «Yuridichna academia Ukraini imeni Yaroslava Mudrogo». Seria: «Filosofia, filosofia prava, politologia, sociologia» [Suicide: causes and ways of prevention. Bulletin of the National University «Yaroslav Mudriy Law Academy of Ukraine». Series: "Philosophy, philosophy of law, political science, sociology»]. № 3 (17). S. 140-160 [in Ukrainian].

10. Pro zatverdzhennya Polozhennya pro poryadok rozsliduvannya neshchasnykh vypadkiv, shcho stalysya iz zdobuvachamy osvity pid chas osvitn'oho protsesu : nakaz Ministerstva osvity i nauky Ukrayiny vid 16 travnya 2019 r. [On approval of the Regulations on the procedure for investigating accidents that occurred to students during the educational process : Order of the Ministry of Education and Science of Ukraine of May 16, 2019]. URL: https://zakon.rada.gov.ua/laws/show/z0612-19\#n (data zvernennia: 05.04.2021) [in Ukrainian].

11. Pro zatverdzhennya Poryadku provedennya rozsliduvannya ta vedennya obliku neshchasnykh vypadkiv, profesiynykh zakhvoryuvan' i avariy na vyrobnytstvi : Postanova Kabinetu Ministriv Ukrayiny № 337 vid 17 kvitnya 2019 r. [On approval of the Procedure for investigation and accounting of accidents, occupational diseases and accidents at work : Resolution of the Cabinet of 
Ministers of Ukraine № 337 of April 17, 2019]. URL: https://zakon.rada.gov.ua/laws/show/3372019-\%D0\%BF\#Text (data zvernennia: 05.04.2021) [in Ukrainian].

12. Pro zatverdzhennya Poryadku rozsliduvannya ta obliku neshchasnykh vypadkiv nevyrobnychoho kharakteru : Postanova Kabinetu Ministriv Ukrayiny № 270 vid 22 bereznya 2001 r. [On approval of the Procedure for investigation and accounting of non-productive accidents : Resolution of the Cabinet of Ministers of Ukraine № 270 of March 22, 2001]. URL: https://zakon.rada.gov.ua/laws/show/270-2001-\%D0\%BF\#Text (data zvernennia: 05.04.2021) [in Ukrainian].

Peresada Olha,

$\mathrm{PhD}$ in Law, Associate Professor

(Donetsk State University of Internal Affairs, Mariupol)

ORCID: https://orcid.org/0000-0001-7199-1938

\section{DETERMINATION OF PREMEDITATED MURDER FROM SUICIDE AND ACCIDENT: THEORETICAL AND METHODOLOGICAL APPROACHES}

The article considers topical issues of definition and qualification of premeditated murder. Intentional homicide has been shown to be distinguished from related and externally similar events, such as suicide and accident. This issue is especially relevant given the fact that a person who committed premeditated murder may knowingly seek to create an environment for incorrect classification of the act. Therefore, it is not possible and not necessary to draw unambiguous conclusions about the legal qualification of such an event solely due to objective circumstances, despite the sometimes obvious nature of the event. The author identified a number of common and distinctive features that should be taken into account by law enforcement agencies during the qualification of an event involving a violent death. An example is the presence and clarity of the reasons for which a person may have committed a probable suicide. However, it is stated that a person's subjective attitude to the act and external signs should be considered only in conjunction with other circumstances. The author also considers certain features of the object, subject, objective and subjective side of premeditated murder, which will be key in resolving the issue of qualification. It was found that the essential features of premeditated murder are its illegality and the intention to take the life of another person, is only in the presence of both of these factors can a legal fact be interpreted as premeditated murder. There are certain signs of an accident that distinguish such an event from premeditated murder. The key is the absence of any form of guilt on the part of the perpetrator. The author also identified a number of features in the presence of which the qualification of the act as premeditated murder should be excluded, for example, the case when the subject of the act and the victim are one and the same person.

Key words: life; criminal law; qualification; premeditated murder; suicide; corpus delicti.

Надіслано до редколегії 06.04.2021

Рекомендовано до публікації 13.04.2021 
DOI: https://doi.org/10.32366/2523-4269-2021-75-2-96-104

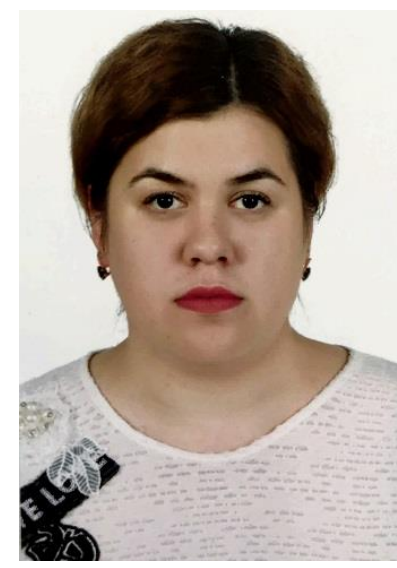

Семенишина-Фіголь Богдана Миколаївна, здобувач

(Донецький державний університет внутрішніх справ, м. Маріуполь)

ORCID: https://orcid.org/0000-0002-0585-9944

\section{ЗЕМЕЛЬНІ ВІДНОСИНИ ЯК ОБ'ЄКТ КРИМІНАЛЬНО- ПРАВОВОЇ ОХОРОНИ В УКРАЇНІ}

Статтю присвячено комплексному дослідженню земельних відносин як об'єкта кримінально-правової охорони й запобігання кримінальним правопорушенням у сфері земельних відносин. Автором сформульовано поняття «земельні відносини». Вивчено чинні законодавчі акти, наукові джерела, щзо дало можливість розкрити сутність та зміст земельних відносин, дослідити сучасний стан публічного управління ними. Запропоновано авторське розуміння сутності земельних відносин як об'єкта кримінально-правової охорони, сукупності відносин у сфері володіння, користування, розпорядження, охорони, ращіонального використання і відтворення земель у межах території Украӥни. На цій основі виокремлено похідні наслідки, що мають економічний характер (у разі заподіяння значної майнової (економічної) шкоди державі, народу Украӥни) та екологічний характер (якщо завдано шкоду довкіллю або створено небезпеку ї̈ заподіяння) $i$ впливають на визначення обсягу призначення покарання за такі кримінально протиправні діяння. Обтрунтовано, щуо співвідношення понять «землі» та «земельна ділянка» як иілого та частини впливає на характеристику об'єкта та предмета кримінальних правопорушень, передбачених відповідними статтями Кримінального кодексу України. Установлено, щуо поняття «землі» є складовою об'єкта кримінального правопорушення, а «земельна ділянка» - ие предмет кримінальних правопорушень.

Ключові слова: земля; земельні відносини; кримінально-правове забезпечення; кримінально-правова охорона.

Постановка проблеми. Згідно зі статтею 14 Конституції України земля є основним національним багатством, що перебуває під особливою охороною держави. Право власності на землю гарантується. Запорукою виконання цих конституційних положень $\epsilon$ встановлення державою ефективного механізму забезпечення права на землю, важливою складовою якого повинні бути й адміністративно-правові засоби, що передбачають відповідальність за порушення такого права. Відповідна норма має вагоме значення для України, аграрної держави, для якої «земельне питання» залишається одним із пріоритетних питань державної політики. Стрімкий розвиток земельних відносин в останнє десятиріччя характеризується не лише позитивними тенденціями, а й має певні негативні риси, пов'язані з неправомірною поведінкою осіб у сфері земельних відносин та збільшенням земельної деліктоздатності [1].

(C) Семенишина-Фіголь Богдана Миколаївна, 2021 
Аналіз останніх досліджень і публікацій. Питанням наукової розробки земельних відносин було присвячено праці таких вітчизняних i зарубіжних учених, як $\begin{array}{lll}\text { Г. М. Беженар, С. С. Бердніков, } & \text { В. К. Гуревський, }\end{array}$ А. М. Мірошниченко, А. А. Рускол, Н. І. Титова та ін. Водночас чимало аспектів залишаються дискусійними та неоднозначними. Зважаючи на це, комплексне дослідження земельних відносин убачається досить актуальним.

Автор ставить за мету на підставі здійсненого аналізу чинних законодавчих актів та наукових джерел розкрити сутність земельних відносин як об'єкта кримінально-правової охорони й запобігання кримінальним правопорушенням у сфері земельних відносин.

Виклад основного матеріалу. Незважаючи на закріплення на найвищому законодавчому рівні особливого статусу землі, стан земельних ресурсів України є близьким до критичного. Так, в ухваленій у 2019 р. Стратегії екологічної політики на період до 2030 р. наводяться дані про те, що: водною та вітровою ерозією уражено близько 57 \% території України; забрудненими є орієнтовно 20 \% земель України; більш як 150 тис. га земель порушені [2]. Природно, що за таких несприятливих обставин Україна як цивілізована держава намагається реагувати на нинішню ситуацію, зокрема, шляхом удосконалення механізму юридичного впливу на порушників земельного законодавства. Ураховуючи те, що останнє не містить усього арсеналу заходів, спрямованих впливати на суб'єктів земельних правопорушень, переважно відповідні правові заходи знаходять закріплення в нормах охоронних галузей права - адміністративного та кримінального. Так, чинний Кримінальний кодекс України (далі - КК України) відзначається наявністю досить розгалуженої системи норм, присвячених регламентації відповідальності за злочини у сфері земельних відносин. До того ж, узгоджуючись з відповідними приписами Конституції України, ця система враховує необхідність кримінально-правової охорони як «власницької» функції, що передбачено статтею 197-1 КК України, так і «екологічної» функції землі як основного національного багатства, що є прерогативою статей 239, 239-1, 239-2 та 254 КК України.

Перехід від адміністративно-директивної до ринкової економіки не може бути безболісним. Ситуація, яка складається на місцях у процесі реформування земельних відносин, зумовлює низку проблем, про що свідчать факти невпинного збільшення випадків незаконного заволодіння земельними ділянками (за показниками Держгеокадастру): здійснено 15594 перевірок дотримання вимог земельного законодавства, винесено 1932 клопотання, 5331 приписів, 4542 протоколи, 4149 постанов про накладення адміністративних стягнень на суму 1,3 млн грн, 1421 матеріал направлено до прокуратори [2]. Також недостатньо реалізується одне 3 головних завдань земельної реформи - раціональне використання та охорона земель. В Україні залишається найвищою у світі розораність сільськогосподарських угідь - 78 \%. Роботи щодо раціоналізації землекористування та охорони земель проводяться досить повільно, унаслідок чого деградація грунтового покриву деяких територій досягла критичного стану. Водночас сучасна система заходів запобігання не здатна вплинути на оптимізацію землекористування та охорони земель, що підтверджують конкретні статистичні дані (за 2015-2020 pp. на 27 \% зменшилася кількість осіб, притягнутих до кримінальної відповідальності за псування і забруднення сільськогосподарських та інших земель). Такі фактичні показники суперечать проголошеному Земельним кодексом України (далі - ЗК України) положенню, що використання власності на землю не може завдавати шкоди правам і свободам громадян, інтересам суспільства, погіршувати екологічну ситуацію і природні якості землі.

Небезпідставність зробленого висновку підтверджується, серед іншого, незначною кількістю осіб, яким вручалося повідомлення про підозру i, відповідно, засуджених за злочинні порушення земельного законодавства. Особливо це стосується земельних злочинів «екологічної» спрямованості: за 2013-2019 рр. повідомленням про підозру закінчилося досудове розслідування лише 84 кримінальних проваджень із 1709, відкритих за статтями 239, 
239-1, 239-2 і 254 КК України (за однією лише статтею 197-1 КК України за вказаний період повідомлення про підозру було вручено 538 особам). Із цією статистикою загалом корелюється і інформація про те, що у 2018-2019 pр. за вчинення злочинів зазначеної категорії було засуджено лише 28 осіб (за статтею 197-1 КК України - 109), що гостро дисонує 3 наведеними вище відомостями про стан дотримання законності у сфері земельних відносин, зайвий раз указуючи на вади кримінально-правової охорони земельних відносин, іiі неефективність [3].

Отже, сьогодні виникла нагальна потреба в детальному дослідженні природи земельних відносин та їх нормативно-правового регулювання, а також у вивченні змісту кримінальних правопорушень у цій сфері та особливостей застосування кримінальноправових санкцій за їх вчинення з метою вдосконалення та підвищення ефективності інституту кримінальної відповідальності.

Значна кількість норм кримінального права, що встановлюють відповідальність за посягання у сфері земельних відносин, вказує на важливість цього напряму. Тому земля як об'єкт охорони держави має надзвичайно важливе значення хоча б тому, що кількість ії не збільшується, а відкриття ринку землі без належного законодавчого врегулювання та відпрацювання схеми відповідальності за вчинені кримінальні правопорушення може призвести до збільшення їхньої кількості в цій сфері та нанесення збитків державним інтересам. Адже залучення землі до вільного обігу на ринку, зважаючи на недосконалість нормативно-правового регулювання таких відносин, спричинить різке збільшення зловживань у цій сфері.

Суттєвим аспектом кримінально-правової охорони земельних відносин $є$ правильне розуміння специфіки вчинення кримінальних правопорушень у цій сфері, їх тісне поєднання в різних складах кримінальних правопорушень, що на практиці створює певні складнощі у кваліфікації дій правопорушників, а це, у свою чергу, призводить до винесення виправдувальних вироків у судах.

Особливе місце в системі суспільних відносин посідають правові відносини. Їх суть полягає в тому, що це відносини, які врегульовані нормами права, їх учасники наділяються взаємними правами та обов'язками. Правові відносини становлять соціальний зв'язок; $\epsilon$ наслідком свідомої вольової діяльності; виникають, припиняються або змінюються, як правило, на основі норм права; вони мають здебільшого двосторонній характер і $є$ особливою формою взаємного зв'язку між конкретними суб'єктами через їхні права, обов'язки i відповідальність; охороняються державою і забезпечуються заходами державного впливу [4, c. 345-347].

Серед них виокремлюються правовідносини, об'єктом яких є землі. Згідно з пунктом 1 статті 2 ЗК України земельні відносини - це суспільні відносини щодо володіння, користування і розпорядження землею [5].

У наукових працях [6; 7] та ЗК України вживається термін «земельні відносини» як тотожний поняттю «земельні правовідносини», тобто використовується синонімічний ряд однотипних термінів. Водночас можна не погодитися з цією точкою зору, оскільки земельні відносини - це відносини загального плану, які не завжди врегульовані нормами права. Натомість земельні правовідносини - це суспільні відносини, що підлягають правовому регулюванню.

Земельні відносини регулюються переважно самостійною галуззю права - земельним правом. Щодо цього Д. М. Лук'янець звертає увагу на той факт, що в значній кількості сфер реалізації виконавчої влади існує, крім адміністративно-правового та кримінально-правового, ще й цивільно-правове регулювання. Це стосується насамперед транспортної, енергетичної, будівельної, аграрної, земельної, банківської та багатьох інших сфер. 3 огляду на це можна, поєднавши відповідні норми, отримати нові, так звані предметні галузі права з аналогічними назвами. Ці галузі права виникли внаслідок логічного розвитку двох зазначених фундаментальних галузей права. Їх (предметні галузі) не можна ставити поруч на один щабель 
у загальній структурі системи права з цивільним або адміністративним правом, оскільки вони $\epsilon$ результатом розвитку останніх $[8$, с. 101$]$.

У ЗК України закріплено, що земельні відносини - це суспільні відносини щодо володіння, користування і розпорядження землею [5]. У своїй сукупності повноваження щодо володіння, користування та розпорядження землею становлять зміст права власності, які мають свої особливості в кожній формі власності на землю (державній, комунальній, приватній).

Відповідно до реальних обставин право власності на землю може бути обмежене законодавством. Обмеження прав на землю викликано обмеженістю земельних ресурсів у природі й неможливістю їх заміни у процесі господарської діяльності [9, с. 125]. Основні обмеження прав на землю закріплені у статті 111 ЗК України, а саме: право на земельну ділянку може бути обмежене законом або договором шляхом встановлення: заборони на продаж або інше відчуження певним особам протягом установленого строку; заборони на передачу в оренду (суборенду); права на переважну купівлю у разі іiі продажу; умови прийняття спадщини тільки визначеним спадкоємцем; умови розпочати і завершити забудову або освоєння земельної ділянки протягом встановлених строків; заборони на провадження окремих видів діяльності; заборони за заміну цільового призначення земельної ділянки, ландшафту та зовнішнього виду нерухомого майна; умови здійснити будівництво, ремонт або утримання дороги, ділянки дороги; умови додержання природоохоронних вимог або виконання визначених робіт; умови надавати право полювання, вилову риби, збирання дикорослих рослин на своїй земельній ділянці в установлений час і в установленому порядку; інших зобов'язань, обмежень або умов. Ці обмеження мають переважно адміністративноправову природу, хоча в окремих випадках вони встановлюються нормами цивільного права. Лише адміністративно-правовими засобами здійснюється державна реєстрація обмежень використання земельної ділянки, що діє протягом терміну, встановленого законом або договором.

Повноваження щодо володіння і користування землею становлять зміст права землекористування. Ці повноваження мають постійні користувачі земельними ділянками державної або комунальної власності (пункт 1 статті 92 ЗК України), тимчасові землекористувачі на основі строкового платного користування на умовах оренди (пункт 1 статті 93 ЗК України) та ін. Землекористувач у процесі її застосування, самостійно здійснюючи ці повноваження, повинен раціонально використовувати земельну ділянку, здійснювати заходи щодо ії відтворення та охорони.

Крім цього, земельні правовідносини мають специфічні особливості залежно від цільового призначення земель. Так, відповідно до статті 19 ЗК України, землі в Україні за цільовим призначенням поділяються на такі категорії: сільськогосподарського призначення; житлової та громадської забудови; природно-заповідного та іншого природоохоронного призначення; оздоровчого призначення; рекреаційного призначення; історико-культурного призначення; лісового фонду; водного фонду; промисловості, транспорту, зв'язку, енергетики, оборони та іншого призначення.

Поняття «земля» у ЗК України не встановлено, однак закріплено в Законі України «Про охорону земель», зокрема, у статті 1 визначено, що земля - це поверхня суші з грунтами, корисними копалинами та іншими природними елементами, що органічно поєднані та функціонують разом з нею [10]. На нашу думку, це поняття не відображає поняття землі як об'єкта правових відносин, а характеризує їі лише як природний ресурс, тому спробуємо з'ясувати значення цього поняття у правовому аспекті.

Термін «земля» прийнято розглядати у двох аспектах. Земля як земна куля, частина космічної матерії, планета Сонячної системи. Вона має природне походження, створена без участі людини і як природний дар належить усьому людству. Земля в цьому розумінні охоплює не лише ії поверхню, а й надра та все з нею пов'язане (грунти, води (поверхневі та підземні), ліси, рослинний і тваринний світ та ін.) [11, с. 9]. 
У підручнику «Земельне право» (1949 р.) за редакцією Н. Д. Казанцева й А. А. Рускола висловлено думку про те, що земля $\epsilon$ всезагальною умовою праці, операційним базисом та основним засобом виробництва в деяких галузях народного господарства [12, с. 3-12].

У Державному стандарті «Земля. Терміни і визначення» земля трактується як найважливіша частина навколишнього природного середовища, що характеризується простором, рельєфом, грунтовим покривом, рослинністю, надрами, водами, є головним засобом виробництва в сільському господарстві, а також просторовою базою для розміщення галузей народного господарства» [13].

Особливе розуміння досліджуваного поняття наведене Н. І. Титовою. Вона зазначає, що категорія «земля» - це певною мірою особливий за походженням, різновид майна, частина матеріального світу, відокремлена від природного середовища працею людини. Категорія «землі» в іiї тлумаченні - це природний компонент, органічна частина довкілля. На іiі думку, лише як природний компонент і складова довкілля земля є об'єктом земельних відносин [14, c. 14]. Хоча ця позиція і не знайшла підтримки в наукових колах, на наш погляд, частіше термін «землі» вживається як узагальнене поняття об'єкта навколишнього природного середовища, а термін «земля» - коли йдеться про неї як об'єкт земельних, цивільних чи адміністративних правовідносин.

Таким чином, пропонуємо статтю 1 ЗК України доповнити пунктом 2 такого змісту: «земля - частина навколишнього природного середовища, яка розташована на поверхні земної кори і характеризується грунтовим покривом, рельєфом, простором, рослинністю, надрами, водними об'єктами, є основним засобом виробництва в сільському і лісовому господарстві та місцем розташування об'єктів нерухомого майна». При цьому пункти 2 та 3 вважати відповідно пунктами 3 та 4.

Земельне законодавство України містить велику кількість норм екологічної спрямованості (наприклад, стаття 167 ЗК України «Охорона земель від забруднення небезпечними речовинами», стаття 168 «Забруднення грунтів» [5], стаття 31 Закону України «Про охорону земель», яка визначає нормативи гранично допустимого забруднення грунтів [10] та ін.). Об'єктом відносин, що закріплені у вказаних статтях, є ні земельна ділянка, ні право на неї, ні на земельний пай. У цьому разі об'єктом є земля саме як природний об'єкт чи природний ресурс, що характеризується екологічними ознаками. У нормативних актах він позначений двома термінами: «землі» чи «грунти». Саме як природний об'єкт земля виконує найважливіші функції: є засобом виробництва в лісовому та сільському господарстві тощо.

Найбільш небезпечними юридичними правопорушеннями у сфері земельних відносин $\epsilon$ кримінальні правопорушення проти порядку охорони земель в Україні, до яких належать самовільне зайняття земельної ділянки (ч. 1, 2 статті 197-1 КК України), забруднення або псування земель (стаття 239 КК України), незаконне заволодіння грунтовим покривом (поверхневим шаром) земель (стаття 239-1 КК України), незаконне заволодіння землями водного фонду в особливо великих розмірах (стаття 239-2 КК України), безгосподарське використання земель (стаття 254 КК України).

Статтями 22-25-1 Закону України «Про охорону навколишнього природного середовища» визначено, що джерелами інформації про стан навколишнього природного середовища є дані моніторингу, кадастрів природних ресурсів, реєстри, автоматизовані бази даних [15].

Інформація як об'єкт земельних відносин має як кримінально-правову, так і цивільноправову природу. Законодавчо закріплено, що така інформація формується переважно спеціально уповноваженими органами управління (у земельних кадастрах, у реєстрах земельних ділянок, прав на них та обмежень на земельні ділянки тощо), а також міститься у цивільно-правових угодах (договорах купівлі-продажу, міни, оренди, земельного сервітуту, іпотеки тощо). Зміст правовідносин щодо інформації про землі та права на них становлять сукупність прав та обов'язків заінтересованих суб'єктів у цій інформації. До таких суб'єктів, наприклад, можуть належати органи земельних ресурсів, 
Суб’єктами земельних відносин в Україні, згідно з пунктом 2 статті 2 3К України, є громадяни, юридичні особи, органи місцевого самоврядування та органи державної влади. Тобто до кола суб'єктів ЗК України відносить осіб, які є суб'єктами права власності на землі й суб'єктами управлінських відносин та які наділені чинним законодавством відповідними правами й обов'язками [5].

Варто акцентувати увагу та погодитися з позицією А. М. Мірошниченка, що не можна обмежувати коло учасників земельних правовідносин суб'єктами права власності. За змістом прав та обов'язків їх поділяють на чотири категорії: органи державної влади та місцевого самоврядування, що мають право на регулювання використання земель; власники землі й землекористувачі - носії прав та обов'язків з раціонального використання й охорони земель; громадські екологічні об'єднання, наділені правом громадського контролю за використанням земель; органи судово-прокурорського нагляду, що здійснюють нагляд за законністю у сфері земельних правовідносин [7, с. 35-36].

Отже, коло суб'єктів правовідносин у сфері володіння, користування і розпорядження землею є вужчим, ніж коло суб'єктів земельних правовідносин.

Земельні ресурси України - найдорожче багатство іï народу. Цінність землі як національного багатства полягає в ії̈ багатофункціональному призначенні. Навкруги нас немає нічого більш вічного, необхідного і незамінного, як земля. Вона є головним засобом виробництва в сільському господарстві та просторовим базисом розміщення та розвитку всіх інших галузей господарства. Про величезне значення землі свідчить і те, що вона не $\epsilon$ продуктом людської діяльності, вона - творіння самої природи, а тому збільшити запаси земельних ресурсів за бажанням чи потребою людини неможливо. Збільшення населення світу вимагає особливої уваги до раціонального використання та охорони земельних ресурсів, оскільки потрібно буде задовольняти потреби населення в сільськогосподарській продукції i створювати сприятливі умови для проживання людей.

Земельні правовідносини - це суспільні відносини, що виникають у зв'язку зі здійсненням прав і законних інтересів власників землі та землекористувачів, їх обов'язків; діяльністю юрисдикційних органів та інших суб'єктів щодо володіння, користування i розпорядження землею, а також іiї раціонального використання, відтворення та охорони.

Земельні відносини становлять коло однорідних суспільних відносин: а) суб'єктами яких можуть бути фізичні, юридичні особи, органи державної влади та місцевого самоврядування, іноземні держави, міжнародні організації, громадські об'єднання та організації - носії суб'єктивних юридичних прав та обов'язків; б) загальним об'єктом яких є земля, а безпосередніми об'єктами можуть бути земельні ділянки, земля як природний ресурс, у тому числі грунти, інформація про землі; в) їх зміст становлять відносини права власності на землю та землекористування, їх раціонального використання, відтворення та охорони, діяльності органів публічного управління, відповідно до специфіки категорій земель, особливостей загального та безпосереднього об'єктів.

Висновки. Отже, варто констатувати, що на всіх етапах свого існування людство тісно пов'язане 3 навколишнім світом, важливим складником якого $є$ земля, що забезпечує задоволення матеріальних, духовних, естетичних, пізнавальних, оздоровчо-лікувальних, рекреаційних, історико-культурних та інших потреб індивіда. Проблеми, пов'язані зі створенням механізму належної охорони цього природного дару, накопичувалися протягом багатьох десятиліть. Вони були зумовлені розвитком науково-технічного прогресу, загальним зростанням чисельності населення планети, його нігілістичним ставленням до земельних ресурсів. У зв'язку з формуванням високоіндустріального суспільства різко посилилося навантаження на окремі об'єкти навколишнього природного середовища й на довкілля в цілому, що негативно впливає на сучасність і загрожує майбутньому кожної людини. Особливої гостроти й широкого масштабу проблема охорони земельних ресурсів набула в середині XX ст., коли суттєво зросла інтенсивність використання останніх, почали більш часто виявлятися негативні екологічні наслідки техногенного характеру: забруднення, засмічення, псування земель, опустелювання і засолення земель сільськогосподарського призначення, 
деградаційні процеси, виснаження грунтів та ін. Такий стан речей викликав потребу в розробці нових і вдосконалення наявних юридичних механізмів забезпечення охорони довкілля в цілому та окремих його елементів, у тому числі й земельних ресурсів.

\section{Список використаних джерел}

1. Конституція України : Закон від 28 черв. 1996 p. № 254к/96-BP. URL: http://zakon2.rada.gov.ua/laws/show/-254\%D0\%BA/96-\%D0\%B2\%D1\%80 (дата звернення: 29.04.2021).

2. Публічний звіт Держгеокадастру за 2015-2020 pp. Держгеокадастр. 2021. URL: http://land.gov.ua/wp-content/uploads (дата звернення: 29.04.2021).

3. Мовчан Р. О. Кримінальна відповідальність за злочини у сфері земельних відносин : автореф. дис. ... канд. юрид. наук : 12.00.08. Київ, 2020. 20 с.

4. Скакун О. Ф. Теорія держави і права : підручник. Харків : Консум, 2001. 656 с.

5. Земельний кодекс України : Закон від 25 жовт. 2001 р. № 2768-III. URL: https://zakon.rada.gov.ua/laws/show/2768-14 (дата звернення: 29.04.2021).

6. Гуревський В. К, Беженар Г. М, Бердніков С. С. Земельне право України : підручник / за ред. О. О. Погрібного, І. І. Каракаша. Київ : Істина, 2003. 448 с.

7. Мірошниченко А. М. Земельне право України : навч. посіб. Київ : Алерта, ЦУЛ, $2011.678 \mathrm{c}$.

8. Лук'янець Д. М. Адміністративно-деліктні відносини в Україні: теорія та практика правового регулювання : монографія. Суми : ВДТ «Університетська книга», 2006. $367 \mathrm{c}$.

9. Аграрное, земельное и экологическое право Украины. Общие части учебных курсов : учеб. пособ. / под ред. А. А. Погребного, И. И. Каракаша. Харьков : Одиссей, 2000. $368 \mathrm{c.}$

10. Про охорону земель : Закон України від 19 черв. 2003 р. № 962-IV. Верховна Рада Украӥни. URL: https://zakon.rada.gov.ua/laws/show/962-15 (дата звернення: 30.04.2021).

11. Шульга М. В. Актуальные правовые проблемы земельных отношений в современных условиях. Харьков : Фирма «Консум», 1998. 224 с.

12. Земельное право : учебник / под ред. Н. Д. Казанцева, А. А. Рускола (сост.). Москва : Госюриздат, 1949. 415 с.

13. ГОСТ 17.5.1.05-80. Охрана природы. Земля. Термины и определения [Утвержден и введен в действие Постановлением Государственного комитета СССР по стандартам от 28 окт. 1985 г.] № 3453.

C. $10-15$.

14. Титова Н. І. Землі як об’єкт правового регулювання. Право Украӥни. 1998. № 4.

15. Про охорону навколишнього природного середовища: Закон України від 25 черв. 1991 р. № 1264-XII. URL: https://zakon.rada.gov.ua/laws/show/1264-12 (дата звернення: 30.04.2021).

\section{References}

1. Konstytutsiia Ukrainy : Zakon vid 28 cherv. 1996 r. № 254k/96-VR. [Constitution of Ukraine : Law from 28 Jun. 1996 № 254K/96-VR]. URL: http://zakon2.rada.gov.ua/laws/show/254\%D0\%BA/96-\%D0\%B2\%D1\%80 (data zvernennia: 29.04.2021) [in Ukrainian].

2. Publichnyi zvit Derzhheokadastru za 2015-2020 rr. Derzhheokadastr [Public report of the State Committee for 2015-2020. State Council]. 2021. URL: http://land.gov.ua/wpcontent/uploads (data zvernennia: 29.04.2021) [in Ukrainian].

3. Movchan, R. O. (2020). Kryminalna vidpovidalnist za zlochyny u sferi zemelnykh vidnosyn : avtoref. dys. ... kand. yuryd. nauk : 12.00.08 [Criminal liability for crimes in the field of 
land relations : abstract of the thesis of the candidate of legal sciences : 12.00.08]. Kyiv. $20 \mathrm{~s}$. [in Ukrainian].

4. Skakun, O. F. (2001). Teoriia derzhavy i prava : pidruchnyk [Theory of State and Law : textbook]. Kharkiv : Konsum. 656 s. [in Ukrainian].

5. Zemelnyi kodeks Ukrainy : Zakon vid 25 zhovt. 2001 r. № 2768-III. [Land Code of Ukraine: Law of 25 October 2001 № 2768-III]. URL: https://zakon.rada.gov.ua/laws/show/2768-14 (data zvernennia: 29.04.2021) [in Ukrainian].

6. Hurevskyi, V. K, Bezhenar, H. M, Berdnikov, Ye. S. (2003). Zemelne pravo Ukrainy : pidruchnyk [Land Law of Ukraine : textbook] / za red. O. O. Pohribnoho, I. I. Karakasha. Kyiv : Istyna. $448 \mathrm{~s}$. [in Ukrainian].

7. Miroshnychenko, A. M. (2011). Zemelne pravo Ukrainy : navch. posib. [Land Law of Ukraine : Tutorial]. Kyiv : Alerta, TsUL. 678 s. [in Ukrainian].

8. Lukianets, D. M. (2006). Administratyvno-deliktni vidnosyny v Ukraini: teoriia ta praktyka pravovoho rehuliuvannia: monohrafiia [Administrative-Dilation Relations in Ukraine: Theory and Practice of Legal Regulation : monograph]. Sumy : VDT «Universytetska knyha». 367 s. [in Ukrainian].

9. Agrarnoe, zemel'noe i ekologicheskoe pravo Ukrainy. Obshchie chasti uchebnyh kursov : ucheb. posob. [Agricultural, Land and Environmental Law of Ukraine. General Parts of Training Courses : tutorial] / pod red. A. A. Pogrebnogo, I. I. Karakasha. Har'kov : Odissej, 2000. 368 s. [in Russian].

10. Pro okhoronu zemel : Zakon Ukrainy vid 19 cherv. 2003 r. № 962-IV [About Land Protection : Law of Ukraine from 19 Jun. 2003 № 962-IV]. URL: https://zakon.rada.gov.ua/laws/show/962-15 (data zvernennia: 30.04.2021) [in Ukrainian].

11. SHul'ga, M. V. (1998). Aktual'nye pravovye problemy zemel'nyh otnoshenij v sovremennyh usloviyah [Actual legal problems of land relations in modern conditions]. Har'kov : Firma «Konsum». 224 s. [in Russian].

12. Zemel'noe pravo : uchebnik [Land Law: textbook] / pod red. N. D. Kazanceva, A. A. Ruskola (sost.). Moskva : Gosyurizdat, 1949. 415 s. [in Russian].

13. GOST 17.5.1.05-80. Ohrana prirody. Zemlya. Terminy i opredeleniya [GOST 17.5.1.05-80. Protection of Nature. Land. Terms and Definitions] [Utverzhden i vveden v dejstvie Postanovleniem Gosudarstvennogo komiteta SSSR po standartam ot 28 okt. 1985 g.] № 3453 [in Russian].

14. Tytova, N. I. (1998). Zemli yak obiekt pravovoho rehuliuvannia. Pravo Ukrainy [Land as an object of legal regulation. The right of Ukraine]. № 4. S. 10-15 [in Ukrainian].

15. Pro okhoronu navkolyshnoho pryrodnoho seredovyshcha : Zakon Ukrainy vid 25 cherv. 1991 r. № 1264-XII [About the protection of the environment : the Law of Ukraine from 25 Jun. 1991 № 1264-XII]. URL: https://zakon.rada.gov.ua/laws/show/1264-12 (data zvernennia: 30.04.2021) [in Ukrainian].

\section{Semenyshyna-Figol Bohdana,}

Postgraduate

(Donetsk State University of Internal Affairs, Mariupol)

ORCID: https://orcid.org/0000-0002-0585-9944

\section{LAND RELATIONS AS AN OBJECT OF CRIMINAL LAW PROTECTION IN UKRAINE}

The article is devoted to a comprehensive study of land relations as an object of criminal law protection and prevention of criminal offenses in the field of land relations. The author formulated the concept of «land relations», and the study of current legislation, scientific sources provided an opportunity to reveal the essence and content of land relations, to explore the current state of public administration. Land legal relations are public relations that exist in connection with the exercise of 
the rights and legitimate interests of landowners and land users, their responsibilities; activities of jurisdictional bodies and other entities regarding the possession, use and disposal of land, its rational use, reproduction and protection. Analysis of current regulations, scientific sources made it possible to reveal the essence and content of land relations, to explore the current state of public administration. Land relations are a circle of homogeneous social relations: the subjects of which may be individuals, legal entities, public authorities and local governments, foreign states, international organizations, public associations and organizations - bearers of subjective legal rights and responsibilities; the common object of which is land, and the direct objects may be land, land as a natural resource, including soils, information about land; their content is the relationship of land ownership and land use, their rational use, reproduction and protection, the activities of public administration, in accordance with the specifics of land categories, features of common and direct objects. Based on modern legal understanding, the principles of criminal law protection of one of the fundamental elements of the environment - land resources as an object of the environment, legal relations of land ownership and agricultural activities. The concept of criminal-legal protection of land resources of Ukraine is developed, which is based on the results of a comprehensive study of the stated issues, taking into account modern views and recent achievements of legal doctrine, which includes the legislator, and man as an integral part of the unified system of the latter, and law enforcement - on the use of regulations not only of criminal law, but also a set of departmental legal acts in the process of criminal law protection of land resources of Ukraine.

Key words: land; land relations; criminal law support; criminal law protection.

Надіслано до редколегії 25.05.2021

Рекомендовано до публікації 27.05.2021 


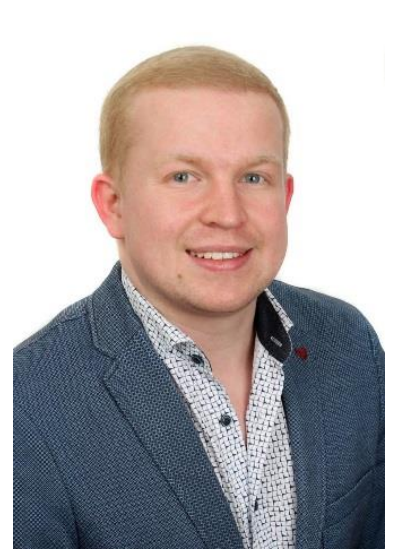

\author{
Синюшко Дмитро Андрійович, \\ аспірант \\ (Національна академія внутрішніх справ, м. Киї) \\ ORCID: https://orcid.org/0000-0003-4293-1105
}

\title{
ДОРЕВОЛЮЦЙНИЙ ПЕРІОД РОЗВИТКУ ЗАКОНОДАВСТВА 3 ПРОТИДІЇ ЗЛОЧИННОСТІ У СФЕРІ ЛІСОВОГО ФОНДУ
}

У статті на основі історично-правового аналізу досліджено еволюиійний розвиток кримінально-правового забезпечення протидії злочинності у сфері лісового фонду на території сучасної України. Автором визначено тендениії історично-правового розвитку кримінально-правової протидї лісопорушенням в Україні, щзо були пов'язані з особливостями становлення права власності на землю, політичного й сочіально-економічного стану суспільства. 3'ясовано, щуо кримінально-правова протидія лісопорушенням у незалежній Україні характеризується пошуком ефективної моделі, щзо значною мірою повинна включати історичний досвід. Здійснено узагальнення, надано рекомендащії щзодо вдосконалення протидіі злочинам у сфері лісового фонду.

Ключові слова:

злочини; злочинність; кримінально-правовий захист; ліс; лісовий фонд; лісопорушення; періодизащія; протидія; шкода.

Постановка проблеми. Людина як частина природи, з одного боку, існує в умовах навколишнього природного середовища, 3 іншого - у процесі своєї життєдіяльності використовує іiі окремі компоненти як ресурси. Тому з самого початку існування людського суспільства здійснювалися заходи, спрямовані на регламентацію використання окремих об'єктів природи.

В Україні сьогодні відбувається зміна так званого «споживацького» підходу щодо використання лісових ресурсів, у зв'язку з чим удосконалюються не тільки організація ведення лісового господарства на засадах сталого еколого-економічного розвитку, а й кримінально-правові заборони в цій галузі. Виникає потреба у вивченні впливу держави на відносини у сфері використання лісового фонду та впровадження історичного досвіду під час розробки подальших ефективних заходів кримінально-правового захисту лісу.

Аналіз останніх досліджень та публікацій. Теоретичні питання кримінальної відповідальності за лісопорушення були предметом досліджень дореволюційних правників, а саме: .В.Вєдрова, М. І. Фалєєва, М.В.Шелгунова. У радянській період вивченням кримінальної діяльності в лісовій сфері займалися В. М. Баландюк, С. О. Боголюбов, I. Ш. Борчашвілі,
Г. І. Вольфман,
В. К. Глистін,
П. С. Дагель,
О. Л. Дубовик,

А. Е. Жалінський, В. О. Лопатін, Ю. І. Ляпунов, В. Д. Пакутін, В. В. Петров та ін.

Після розпаду Союзу Радянських Соціалістичних Республік окремі аспекти цієї проблеми досліджувалися в працях Д. В. Басаєва, Н. В. Вірясової, С. Б. Гавриша, Б. М. Головкіна, О. О. Дудорова, В. П. Смельянова, . В. Кіндюка, І. О. Конфоркіна, $\begin{array}{lll}\text { 3. Г. Корчевої, } & \text { В. К. Матвійчука, Н. А. Мірошниченко, В. О. Навроцького, }\end{array}$ 
Е. І. Немировського, В. І. Осадчого, О. В. Сасова, М. О. Селякова, О. Г. Сімонова, О. В. Скворцової, М. О. Соколова, В. В. Сташиса, Є. Л. Стрельцова, А. Л. Сулейманова, В. Я. Тація, І. Г. Травіної, О. В. Шаріпової, Ю. С. Шемшученко, Д. Б. Чуракова та ін.

Результати досліджень цих авторів є важливими як для науки, так і для практики протидії злочинності у сфері лісового фонду. Проте зазначеними вченими недостатньо приділено уваги питанням щодо історичних періодів здійснення кримінально-правової протидії та факторів, які формували ії особливості в конкретну історичну епоху.

Метою статті $\epsilon$ 3'ясування історико-правових аспектів розвитку кримінально-правової протидії злочинності у сфері лісового фонду України для подальшого вдосконалення діяльності суб'єктів протидії.

Виклад основного матеріалу. Вивчення історичної та юридичної літератури дає змогу зробити висновок про те, що історія українського кримінального законодавства у сфері охорони лісу охоплює три хронологічних періоди: перший період (дореволюційний) - з часів «Руської Правди» й до 1917 р.; другий період (радянський) - з 1917 до 1991 рр.; третій період (пострадянський) - з 1991 р. і дотепер.

Розглядаючи перший період, необхідно зазначити, що особливістю природокористування в Київській Русі була майже невичерпність природних багатств за порівняно невеликої кількості населення. Якщо нині в Україні площі лісів становлять 15 \%, то за часів прийняття «Руської правди» цей природний ресурс займав 40-50 \% території країни $[10$, c. 53].

Природні умови склалися так, що межа між лісом та степом не була чітко вираженою. Розташування населених пунктів вирішувало цілу низку важливих питань. По-перше, ліс слугував об'єктом промислів, полювання, бортництва. По-друге, дерева вирубували, корчували для розширення сільськогосподарських площ, пасовищ для випасу худоби, луків для збирання сіна. По-третє, у лісі завжди можна було сховатися від набігів кочівників [9, с. 9].

Це був той історичний період, коли обсяг лісу надзвичайно перевищував потребу в ньому. Тому вогнищева заготівля деревини зовсім не впливала на стан екосистеми, а охорона навколишнього середовища не розглядалася як актуальна проблема. Захист закону поширювався на природні ресурси як об’єкти права власності феодалів, громади, а згодом і церкви.

Перші вітчизняні ранньофеодальні законодавчі акти з охорони природи з'явилися в XXI століттях. Літописи містять дані про те, що ще в середині X ст. на законодавчій основі відбувся розподіл земель і лісових угідь. Княгиня Ольга проголосила лісові мисливські угіддя недоторканною приватною власністю київського престолу. Князь Володимир Великий закріпив ці правові акти в «Уставі земельному» [14, с. 56].

«Руська Правда» Ярослава Мудрого (1016 р.) встановлювала стягнення (штраф) за крадіжку дров, а не за рубання лісу - власності всієї общини. Водночас передбачався штраф за пошкодження або знищення борті. Охорона лісів регламентувалася також у Статуті князя Ярослава Мудрого «Про церковні суди і земські справи».

Починаючи з XIV ст., частина українських земель потрапила у сферу політичного впливу Великого Князівства Литовського. Найважливішим джерелом доходів влади було використання лісів 3 метою вивозу деревини та продукції промислів за кордон. Незважаючи на наявність значного виробництва, кількість спалюваного лісу на початок XVI ст. не впливала на екологію. Цілком імовірно, ця обставина відобразилася в тому факті, що в Статуті Великого Князівства Литовського 1529 р. немає положень щодо захисту лісу від пожеж [15].

Ситуація змінюється за часів правління великого князя Сигізмунда-Августа II, який надавав велике значення розвитку лісової галузі. 3 ім'ям цього правителя пов'язане прийняття низки законодавчих актів, які тією чи іншою мірою стосуються збереження лісів: Уставу на волоки 1557 р., Лісового уставу 1567 р. і Статуту Великого Князівства Литовського 1566 p. Так, питання, пов'язані зі спалюванням лісів на поташ, закріплені в Лісовому уставі 1567 p. [10, с. 207] Один із пунктів документа регламентує суворий контроль великокнязівських 
лісничих за спалюванням лісу для виробництва поташу. Закон дозволяє виконувати ці роботи лише з особистого дозволу князя та з дотриманням заходів із захисту лісів від пожеж.

На значно вищому рівні юридичної техніки зафіксовані норми щодо охорони лісів у Статуті Великого Князівства Литовського 1566 р. (далі - Статут), який отримав назву Волинського. Розділ 10 арт. 17 Волинського статуту також установлював за пожежу в лісі смертну кару з відшкодуванням збитків [15, с. 365]. У Статуті було вказано досить широке коло людей, які можуть бути організаторами пожежі. Це торговці, які проїжджають через ліси та залишаються ночувати в них, пастухи, які пасуть коней, худобу на луках, розташованих поряд з лісами. При цьому Статут не поділяв причини займання лісу на умисні або випадкові, тому що прирівнював між собою ці діяння.

Подальший розвиток законодавства Великого Князівства Литовського тісно пов'язаний із прийняттям 10-12 квітня 1569 р. Люблінської унії. Складання цього документа й утворення єдиної держави порушили питання про уніфікацію чинного законодавства. У результаті було прийнято в 1588 р. Статут, який отримав назву Нового. У Статуті 1588 р. проблемам регламентації захисту лісів присвячений арт. 17 «Про пожежі в пущах і лісах» розділу 10 «Про пущі, про лови, про дерево бортне, про озера та сіножаті» [17, с. 14].

Слід зазначити, що лісове законодавство XV-XVI століть було непослідовним. Майже всі ліси, що не мали оборонного значення та не знаходилися особливо під охороною, перебували у вільному користуванні держави й громадян [9, с. 10]. Цей підхід застосовувався і в низці нормативних актів, які поширювалися на територію України навіть після її входження до складу Московії.

Основним джерелом права Московської держави на території Слобожанщини було Соборне Уложення 1649 р. Відповідно до нього було заборонено вирубування засічного лісу навіть людям, які перебували на військовій службі. У разі такого діяння створювалася комісія, що визначала розмір завданої шкоди. Лісовою охороною того часу був Помісний приказ, чиновники якого оцінювали розмір втрат і вживали заходів із розшуку винних [5, с. 231].

Також Соборне Уложення 1649 р. закріплювало право на земельну власність. При цьому до структури вотчин і помість, як правило, входили й ліси, але власникові було заборонено вирубувати їх, вивозити деревину, а також використовувати цей природний ресурс на свій розсуд. Соборне уложення 1649 р. передбачало відповідальність за знищення або пошкодження лісу пожежею [6, с. 11].

В Україні XVI-XVII століть особливість організації природоохоронної діяльності багато в чому визначалася автономною від держави юридичною практикою Запорозької Січі. Стосовно безпосередньої території сучасної України в період XVI-XIX століть, то аналіз архіву коша Запорозької Січі (документів центральних і місцевих органів влади Запорозької Січі XVI-XVIII століть) дає змогу стверджувати, що природоохоронні норми на цій території стосувалися насамперед збереження і раціонального використання лісових ресурсів [12, с. 27].

На території Запорозьких Вольностей, яка становила у XVIII ст. площу приблизно 11 млн десятин, лісові масиви займали близько 800 тис. десятин (близько 7 \%). Ліси росли переважно в долинах річок Дніпра, Орелі, Самари, Самоткані, Вовчої, а також у низинах уздовж берегів менших рік, озер, лиманів, на дніпровських островах, у байраках і плавнях. Найбільш залісеними були північні паланки: Орільська, Самарська і Протовчанська [8].

На території Запорозької Січі був установлений чіткий порядок користування лісами. За усними правилами дозволялося використовувати з господарською метою лише сухі дерева, а ліс рекомендувалося зберігати для нащадків. Для опалення можна було використовувати лише сухе чи лежаче дерево. Вирубування лісу не регламентувалося окремими правилами, але його пропонувалося застосовувати економно або, говорячи сучасною мовою, «бережливими методами» [7, с. 168]. Користуватися лісом у Запорозькій Січі для власних потреб без особливого дозволу мали право тільки козаки та піддані Війська Запорозького, а сторонні особи мали обов'язково отримати на це дозвіл коша або кошового отамана [4, с. 103]. Звертаючись за дозволом, потрібно було зазначити: скільки, якого саме лісу й для яких потреб 
необхідно. А для затримування осіб, що самовільно вирубують ліс, козаки організовували спеціальні команди. Також окремі лісові ділянки на основі «ордерів» віддавали під охорону козакам (наприклад, власникам слобод) на підставі спеціальних ордерів. Порушники підлягали арешту разом з тим майном, яке вони мали при собі (сокира, худоба, віз тощо), про що негайно сповіщали кіш. Затриманим загрожували санкції у вигляді втрати чину, тілесних покарань та конфіскації майна. У разі невиконання умов про охорону лісу від знищення власник ділянки позбувався права володіти нею, після чого лісову ділянку могли передати іншому козакові [4, с. 104].

Після остаточного переходу України під протекторат Росії російські закони поступово імплантувалися в українське правове поле. Так, правління Петра I супроводжувалося розширенням промисловості, торгівлі, транспорту, стрімкою розбудовою поселень. У цей період загострилися проблеми збереження природних ресурсів в освоєних районах як об'єктів права власності та сировини, необхідного для розвитку господарства, військової справи, виробництва продовольства.

Царськими указами були введені обмеження, а іноді й заборони рубок лісу в районах великих міст і в деяких інших частинах країни. Установлювалися водоохоронні заповідні зони. Так, А. Я. Антонович вказував: «У 1703 р. Петро наказав описати ліси на відстані 50 верств від великих річок і 20 верств від малих. На цьому просторі деякі лісові породи оголошені заповідними, тобто такими, що належать державі й не можуть бути вирубаними не тільки сторонніми людьми, а й самими власниками [2, с. 14-15]. Передбачалися суворі санкції за незаконну порубку заповідних дерев аж до смертної кари.

Крім того, законодавцем був передбачений механізм заохочення особи, яка виявила незаконну рубку, а також правило крайньої необхідності, що виключає кримінальну відповідальність за рубку дерев [2, с. 15].

Щодо українських земель, то у 1703 р. було видано указ, яким були заповідані дубові ліси, у тому числі Леонтіїв Яр у Харківській губернії, та визначалося, що всі ліси, включаючи й приватні, - надбання держави та їх використання має підпорядковуватися насамперед державним інтересам, а в 1710 р. вийшов указ про охорону лісів уздовж берегів річок.

Н. В. Вірясова зазначає, що проведена на законодавчому рівні за часів Петра I класифікація лісів (залежно від їхньої важливості й цінності) дозволила здійснити диференціацію кримінальної відповідальності за їх незаконну порубку. Вперше під час формулювання кримінально-правових норм законодавець чітко визначив і розкрив ознаки незаконності посягання [3, с. 29].

Важливим етапом розвитку українського законодавства стала підготовка кодексу, що отримав назву «Права, за якими судиться малоросійський народ» 1743 р. [13]. Незважаючи на те, що офіційно кодекс не вступив у дію, за ним вивчали українське право, робили окремі посилання в судовій практиці. Природним об'єктам присвячені відповідно такі розділи: 17 земельному праву; 18 - водному; 19 розділ містить норми, що стосуються лісів і лісових промислів та угідь, а також міських сервітутів [13, с. 335].

Артикул перший 19 розділу передбачав відповідальність у формі штрафу за свавільну (злодійську) порубку лісового або садового дерева. Артикул п'ятий регламентував відповідальність та відшкодування збитків за навмисне та ненавмисне пошкодження бортного дерева. Окрема стаття (артикул сьомий) визначала правозастосовні дії у разі навмисного та ненавмисного вчинення пожежі в пущах, лісах і в степу [13, с. 339].

Однак, незважаючи на певну специфіку вітчизняного правового поля в галузі охорони лісів, усі закони, починаючи з XVIII ст., мали загальноросійський характер. Природоохоронні укази Петра I виконувалися з великою суворістю, але за часів правління наступних царів увага до них послабла. Так, Катерина II видала указ від 22 вересня 1782 р., який віддавав у повну власність власникам маєтків усі ліси, що ростуть на дачах поміщиків, навіть якщо вони були раніше оголошені заповідними. Хоча пізніше Павло І знову ввів обмеження на рубку лісу.

Після затвердження в 1826 р. Положення «Про новий устрій лісової частини» особливу увагу звернули на з'ясування питань щодо провадження слідства з лісових порубок; про судові 
місця, що розглядали ці злочини; а також про обставини, що збільшують вину порубників, на які мали зважати під час ухвалення рішень. Ці норми широко застосовувалися 3 метою протидії злочинам. Згідно зі звітом Міністерства юстиції, протягом 1860 р. за незаконну порубку казенних (тобто державних) лісів було висунуто звинувачення 17641 особам, що становило $25 \%$ від загальної кількості всіх обвинувачених за різні злочини (72489 осіб), 5 винних було засуджено до заслання, 34 направлено в арештантські роти [1].

3 розвитком промисловості та через активне освоєння природних багатств починає усвідомлюватися екологічна функція лісових ресурсів, проте здебільшого пріоритет у захисті природи закріплювався за інтересами власників. Характерно, що кримінально-правові норми того періоду, в тому числі ті, які регламентують відповідальність за лісопорушення, розміщувалися в різних нормативних джерелах.

Так, Статут Лісовий, який увійшов до Зводу законів Російської імперії 1842 р., містив велику кількість норм, що регулюють як лісокористування, так і відповідальність за проступки і злочини в цій сфері, які мали невеликий ступінь суспільної небезпеки, а покараннями за їхнє вчинення визначалися переважно грошові стягнення [1].

Більш суворі санкції за злочинні лісопорушення були в Уложенні про покарання кримінальні і виправні 1845 р. (далі - Уложення 1845 р.), яке включало досить великий список злочинів і проступків проти природних об'єктів. Його норми передусім забезпечували охорону інтересів держави та приватних осіб як власників природних ресурсів.

Учені того часу зараховували лісопорушення до злочинів проти власності, а суспільну небезпечність таких діянь убачали лише в небезпеці для життя людини, але не для екологічної системи в цілому [11, с. 597].

В Уложенні 1845 р. охороні лісу вперше була присвячена окрема глава. Це дає підставу стверджувати про появу самостійного видового об'єкта - суспільних відносин, що забезпечують охорону й раціональне використання казенних лісів.

Так, у розділі 7 «Про злочини і проступки проти майна та доходів казни» в главі 9 «Про порушення статутів про казенні ліси» міститься 67 статей, присвячених незаконному використанню лісів. Статті згруповані в 4 відділи:

1) про покарання і стягнення за викрадення і самовільну порубку казенного лісу;

2) про покарання і стягнення за пошкодження лісів, самовільний видобуток в лісах смоли та дьогтю, пошкодження дерев та інші порушення правил Статуту Лісового;

3) про особливі покарання і стягнення за викрадення, порубку та пошкодження лісів корабельних;

4) про покарання і стягнення за злочини та проступки лісових чинів і служителів.

Основний склад незаконної порубки розкритий у ст. 941 Уложення 1845 р. Для визначення покарання за злочин законодавець посилається на ст. 2159 Уложення 1845 р., в якій розкривається санкція за вчинення крадіжки. Покарання у вищевказаній статті диференціювалося залежно від розміру шкоди й кількості притягнень до відповідальності за аналогічні діяння.

Як покарання застосовуються: позбавлення всіх прав; заслання; направлення в робочий будинок; різки; направлення у виправні арештантські роти цивільного відомства. Додатково до цього на винного накладається грошове стягнення, яке дорівнює ціні викраденого лісу. Незаконно заготовлений ліс вилучається. Якщо селянин, який вчинив незаконну рубку, не в змозі виплатити грошове стягнення, таке зобов'язання в багатьох випадках могло бути перекладене на громаду.

До обтяжуючих обставин законодавець відносив: 1) незаконну рубку дубових, саджених і сіяних лісів; 2) вчинення спротиву лісовій сторожі без насильства; 3) вчинення спротиву сторожі із застосуванням насильства (у такому разі покарання призначаються як за злочини проти влади).

У систему лісових проступків поряд 3 незаконною рубкою були включені також: свідоме укриття викраденого лісу або його переробка, переруб понад встановлену кількість, 
рубка на відстані до річки ближче, ніж зазначено в квитку, рубка на невідведеній для цього ділянці, рубка в неналежний строк, розчищення лісових угідь під ріллю або випас без дозволу, пошкодження дерев.

Значна кількість норм, спрямованих на охорону лісу від злочинних посягань, встановлювали відповідальність за пошкодження та знищення лісу вогнем. До того ж Уложення 1845 р. зазнало казуального опису норм і диференціювало покарання залежно від способу діянь, що викликали однакові негативні наслідки. Так, була низка однорідних статей за необережне поводження з вогнем у лісах, де склади розрізнялися лише дією, яка, на думку законодавця, 3 більшою або 3 меншою ймовірністю (ступенем небезпеки) могла через необережність призвести до пошкодження і знищення лісу: за випалювання рослинності, за розпалювання вугілля, приготування поташу, куріння тютюну та ін. Передбачалася відповідальність також і за бездіяльність: той, хто помітив пожежу та не вжив заходів для гасіння вогню біля лісу, підлягав штрафу в розмірі 15 коп.

Суворі заходи відповідальності встановлювалися щодо чиновників лісового господарства і службовців за дозвіл самовільної порубки лісу або за участь у таких діяннях (штрафи, ув'язнення, заслання до Сибіру).

Уложення 1845 р. стало суттєвим кроком вперед у розвитку норм кримінально-правової протидії лісовим злочинам, оскільки заклало підвалини для сучасного уявлення про об’єктивну сторону таких злочинів.

Подальше дореволюційне законодавство не містило кардинальних змін. Уложення 1845 р. зазнало безліч змін і кілька видань, які відбулися в 1857, 1866 і 1885 роках.

У 1903 р. було частково введено в дію нове Кримінальне Уложення. Більшість статей, які охороняють природні ресурси, були згруповані в одній новій главі 11 «Про порушення постанов про захист народного добробуту», що було досить прогресивним кроком, однак вона так і не набула чинності до 1917 р.

Висновки. У підсумку зауважимо, що дореволюційний період умовно поділяють на чотири етапи розвитку кримінально-правової протидії злочинам у сфері лісового фонду:

1) «звичаєвий період»: коли панувало звичаєве право, а ліс не був специфічним об’єктом правового захисту. Були лише заборони через релігійні мотиви;

2) «початковий період»: поява письмових джерел права, що регламентують відповідальність за лісопорушення. Предметом охорони були окремі бортні дерева і право власності на них;

3) «функціональний період»: захисту підлягали ліси 3 метою збереження виконуваних ними корисних для людини функцій - як місця проживання тварин, військових цілей, стратегічної сировини, об'єкта власності. Виникнення відповідальності за лісові пожежі як стихійного лиха;

4) 《прогресивний період»: відбувається розвиток інститутів кримінально-правової охорони лісу як майна і частково як елемента природного середовища від розкрадання, пошкодження і знищення. Розділена відповідальність за порубку й розкрадання лісу. Зазначений період заклав основу сучасної кримінально-правової протидії злочинам у сфері лісового фонду.

Крім того, актуальним нині $\epsilon$ історичний досвід формулювання норм, що регламентують відповідальність за злочинні лісопорушення:

- шляхом уведення в норми таких елементів, які максимально мотивують лісопорушників до утримання від злочинних посягань та спричиняють моральний осуд таких діянь;

застосування заходів стимулювання порубників до сумлінного лісокористування, навіть у разі скоєння порушення, шляхом повідомлення про нього i включення посиленого покарання за приховування такого порушення;

небезпеки в лісах; шляхом диференціації відповідальності залежно від ступеня пожежної

- віднесення до ознак складу злочину, скоєного шляхом знищення або 
пошкодження пожежею лісових насаджень, місця скоєння таких діянь поблизу населених пунктів.

\section{Список використаних джерел}

1. Автономов С. В., Соболь И. А. Развитие российского уголовного законодательства в сфере противодействия экологическим преступлениям: историческая динамика и тенденции. Вестник Санкт-Петербургского университета МВД России. 2009. T. 43. C. 27-34.

2. Антонович А. Я. Курс государственного благоустройства (полицейского права). Ч. 2. Киев, 1890.320 с.

3. Вирясова Н. В. Уголовно-правовые меры борьбы с незаконной рубкой лесных насаждений : дис. ... канд. юрид. наук. М., 2007. 197 с.

4. Грозовський І. Охорона природи в Запорозькій Січі. Право України. 1997. № 12. C. 103-105.

5. Киндюк Б. В. Правові засади охорони лісів на Слобожанщині. Право $і$ безпека. 2009. № 1. С. 231-234.

6. Киндюк Б. В. Правові засади охорони лісів у Соборному уложенні 1649 р. Підприємництво, господарство і право. 2009. № 9. С. 11-13.

7. Кіндюк Б. В. Правові засади охорони лісів на землях Козацької України. Право України. 2009. № 8. С. 166-170.

8. Кіндюк Б. В., Патлачук В. Н., Патлачук О. В. Природокористування та охорона навколишнього середовища на землях Запорізького козацтва. Український географічний журнал. 2019. № 4. С. 49-56.

9. Лазаренко Я. Розвиток лісового законодавства України. Право Украӥни. 2003. № 2. C. 131-135.

10. Логвиненко О. Н. Лісоохоронна справа в Україні: історико-правовий аспект (IX ст. - 1990 р.) : автореф. дис. ... канд. юрид. наук : 12.00.01 / Київ. нац. ун-т внутр. справ. К., 2006. 19 c.

11. Лохвицкий А. В. Курс русского уголовного права. СПб. : Издание журнала Министерства юстиции, 1867. 662 с.

12. Повелицына П. Ф. Уголовно-правовая охрана природы в СССР. М. : Юридическая литература, 1981. 88 с.

13. Права, за якими судиться малоросійський народ. 1743 р. / відп. ред. Ю. С. Шємшученко; упоряд. К. А. Вислобоков. К. : «Пам’ятники політико-правової культури України», 1997. 547 с.

14. Российское законодательство X-XX веков : в 9 т. М. : Юридическая литература, 1984. Т. 1 : Законодательство Древней Руси. 432 с.

15. Статути Великого князівства Литовського : у 3 т. / за ред. С. Ківалова, П. Музиченка, А. Панькова. О. : Юрид. літ., 2002. Т. I : Статут Великого князівства Литовського 1529 року. 464 с.

16. Статути Великого князівства Литовського : у 3 т. / за ред. С. Ківалова, П. Музиченка, А. Панькова. О. : Юрид. літ., 2002. Т. II : Статут Великого князівства Литовського 1566 року. 560 с.

17. Харитонов С. О., Харитонова О. І. Рецепція римського права у Статутах Великого князівства Литовського: чинники, передумови та деякі результати. Актуальні проблеми держави і права. 2009. № 49. С. 14-23.

\section{References}

1. Avtonomov, S. V., Sobol', I. A. (2009). Razvitie rossijskogo ugolovnogo zakonodatel'stva $\mathrm{v}$ sfere protivodejstviya ekologicheskim prestupleniyam: istoricheskaya dinamika $\mathrm{i}$ 
tendencii [Development of Russian criminal legislation in the field of countering environmental crimes: historical dynamics and trends]. Vestnik Sankt-Peterburgskogo universiteta MVD Rossii. T. 43. S. 27-34 [in Russian].

2. Antonovich, A. YA. (1890). Kurs gosudarstvennogo blagoustrojstva (policejskogo prava) [Course of state improvement (police law)]. CH. 2. Kiev. 320 s. [in Russian].

3. Viryasova, N. V. (2007). Ugolovno-pravovye mery bor'by s nezakonnoj rubkoj lesnyh nasazhdenij [Criminal legal measures to combat illegal logging of forest plantations] : dis. ... kand. yurid. nauk. M. 197 s. [in Russian].

4. Hrozovskyi, I. (1997). Okhorona pryrody v Zaporozkii Sichi [Nature Protection in Zaporozhye Sich]. Pravo Ukrainy. № 12. S. 103-105 [in Ukrainian].

5. Kyndiuk, B. V. (2009). Pravovi zasady okhorony lisiv na Slobozhanshchyni [Legal principles of forest protection in Slobozhanshchyna]. Pravo $i$ bezpeka. № 1. S. 231-234 [in Ukrainian].

6. Kyndiuk, B. V. (2009). Pravovi zasady okhorony lisiv u Sobornomu ulozhenni 1649 r. [Legal principles of forest protection in Cathedral Election 1649]. Pidpryiemnytstvo, hospodarstvo i pravo. № 9. S. 11-13 [in Ukrainian].

7. Kindiuk, B. V. (2009). Pravovi zasady okhorony lisiv na zemliakh Kozatskoi Ukrainy [Legal principles of forest protection on the lands of Cossack Ukraine]. Pravo Ukrainy. № 8. S. 166170 [in Ukrainian].

8. Kindiuk, B. V., Patlachuk, V. N., Patlachuk, O. V. (2019). Pryrodokorystuvannia ta okhorona navkolyshnoho seredovyshcha na zemliakh Zaporizkoho kozatstva [Environmental protection and environmental protection on the lands of Zaporozhye Cossacks]. Ukrainskyi heohrafichnyi zhurnal. № 4. S. 49-56 [in Ukrainian].

9. Lazarenko, Ya. (2003). Rozvytok lisovoho zakonodavstva Ukrainy [Development of forest legislation of Ukraine]. Pravo Ukrainy. № 2. S. 131-135 [in Ukrainian].

10. Lohvynenko, O. N. (2006). Lisookhoronna sprava v Ukraini: istoryko-pravovyi aspekt (IX st. - 1990 r.) [Forestry Case in Ukraine: Historical and Legal Aspect (IX Art. - 1990)] : avtoref. dys. ... kand. yuryd. nauk : 12.00.01 / Kyiv. nats. un-t vnutr. sprav. K. 19 s. [in Ukrainian].

11. Lohvickij, A. V. (1867). Kurs russkogo ugolovnogo prava [Russian criminal law]. $\mathrm{SPb}$. : Izdanie zhurnala Ministerstva yusticii, $662 \mathrm{~s}$. [in Russian].

12. Povelicyna, P. F. (1981). Ugolovno-pravovaya ohrana prirody v SSSR [Criminal legal protection in the USSR]. M. : YUridicheskaya literatura, $88 \mathrm{~s}$. [in Russian].

13. Prava, za yakymy sudytsia malorosiiskyi narod $1743 \mathrm{r}$. [The rights under which the Little Russian people are sued] / vidp. red. Yu. S. Shiemshuchenko; uporiad. K. A. Vyslobokov. K. : «Pamiatnyky polityko-pravovoi kultury Ukrainy», 1997. 547 s. [in Ukrainian].

14. Rossijskoe zakonodatel'stvo $\mathrm{X}-\mathrm{XX}$ vekov [Russian legislation of the $\mathrm{X}-$ XX centuries] : v 9 t. M. : YUridicheskaya literatura, 1984. T. 1 : Zakonodatel'stvo Drevnej Rusi. 432 s. [in Russian].

15. Statuty Velykoho kniazivstva Lytovskoho [Statutes of the Grand Duchy of Lithuanian] : u 3 t. / za red. S. Kivalova, P. Muzychenka, A. Pankova. O. : Yuryd. lit., 2002. T. I : Statut Velykoho kniazivstva Lytovskoho 1529 roku. 464 s. [in Ukrainian].

16. Statuty Velykoho kniazivstva Lytovskoho [Statutes of the Grand Duchy of Lithuanian] : u 3 t. / za red. S. Kivalova, P. Muzychenka, A. Pankova. O. : Yuryd. lit., 2002. T. II : Statut Velykoho kniazivstva Lytovskoho 1566 roku. 560 s. [in Ukrainian].

17. Kharytonov, Ye. O., Kharytonova, O. I. (2009). Retseptsiia rymskoho prava u Statutakh Velykoho kniazivstva Lytovskoho: chynnyky, peredumovy ta deiaki rezultaty [Reception of Roman law in the statutes of the Grand Duchy of Lithuania: Factors, Prerequisites and some results]. Aktualni problemy derzhavy i prava. № 49. S. 14-23 [in Ukrainian]. 
Sinyushko Dmytro,

Postgraduate student

(National Academy of Internal Affairs, Kyiv)

ORCID: https://orcid.org/0000-0003-4293-1105

\section{PREREVOLUTIONARY PERIOD OF DEVELOPMENT OF LEGISLATION AGAINST CRIME IN THE FIELD OF FOREST FUND}

The article, based on historical and legal analysis, examines the evolutionary development of criminal law support for combating crime in the field of forest resources in modern Ukraine. The author identifies trends in the historical and legal development of criminal law counteraction to forest violations in Ukraine, which were associated with the peculiarities of land ownership, political and socio-economic status of society. The study found that criminal law counteraction to forest violations in independent Ukraine is characterized by the search for an effective model, which should largely include historical experience. Generalizations were made, recommendations were given to improve the fight against crimes in the field of forest resources. The study of historical and legal literature makes it possible to conclude that the history of Ukrainian criminal law in the field of forest protection covers three chronological periods: the first period (pre-revolutionary) - from the times of «Ruska Pravda» and until 1917; second period (Soviet) - from 1917 to 1991; third period (post-Soviet) since 1991. It is important to note that natural conditions have developed so that the boundary between the forest and the steppe was not clearly expressed. The location of settlements has solved a number of important issues. First, the forest served as an object of crafts, hunting, boarding. Secondly, the trees were cut down, cocturns for expansion of agricultural areas, pastures for grazing livestock, meadows for harvesting hay. Thirdly, in the woods could always be hiding from raids of nomads. So in addition, can conclude that the historical experience of the formulation of norms regulating the responsibility for criminal offices is now relevant: by introducing in the norm of such elements, which maximally motivate the foresters to hold from criminal encroachments and cause moral condemnation of such acts; use of stimulating the rails to conscientious forest use, even in the case of committing a violation, by reporting it and the inclusion of an enhanced punishment for concealing such a violation; by differentiation of responsibility, depending on the degree of fire hazard in forests; introduction to the signs of a crime committed by destroying or damaging forest plantations, the location of such acts near settlements.

Key words: counteraction; crimes; criminal legal protection; criminality; damage; forest fund; forest violations; forest; periodization. 
УДК: 343.135 (477)

DOI: https://doi.org/10.32366/2523-4269-2021-75-2-114-123

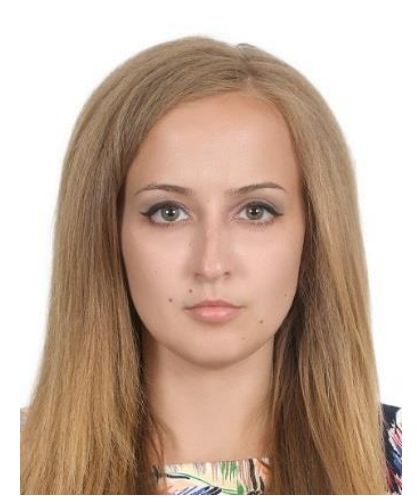

Тіточка Тетяна Ігорівна, кандидатка юридичних наук

(Донецький державний університет

внутрішніх справ, м. Маріуполь)

ORCID: https://orcid.org/0000-0002-5924-614X

\section{РОЛЬ НЕПОВНОЛІТНЬОЇ ЖЕРТВИ В МЕХАНІЗМІ ПЕРВЕРСИВНОЇ КРИМІНАЛЬНО ПРОТИПРАВНОЇ ПОВЕДІНКИ}

У статті автор розглядає роль неповнолітньої жертви в механізмі перверсивної кримінально протиправної поведінки. Указується, щчо перверсивна поведінка апріорі свідчить насамперед про втрату особою моральних иінностей та викривлення адекватного світосприйняття, щуо відбувається внаслідок певних психічних / психологічних відхилень. Перверсія не завжди стає першопричиною кримінально протиправної поведінки та за своєю сутністю є лише збоченим уявленням про статеві взаємовідносини. Однак окремі види сексуальних відхилень вимагають від особи вчинення протиправних дій, які дозволять йому отримати статеве збудження та його логічний фінал. У иъьому контексті мова йде про педофілію (у т. ч. інцестного типу), некрофілію, примушування до вступу у статеві відносини (згвалтування, сексуальне насильство тощо). Автор доводить, щзо кримінально протиправна поведінка особи, яка вчиняє щзодо неповнолітнього сексуальне кримінальне правопорушення, здебільшого мотивована фізіологічною та психічною потребою задовольнити статевий потяг. Більшість таких протиправних діянь вчиняються у стані алкогольного сп'яніння, котре полегшує насильнику процес усвідомлення свого протиприродного бажання, остаточно формуючи виникнення прямого умислу. Якщо мова йде про психічнохвору людину, то в неї ией умисел сформований та повторюваний (багатоактний). Жертва є чентром мотивації, формуючи та обумовлюючи ї̈ реалізацію. Тому неповнолітній віктим інтегрований $у$ суб'єктивний компонент поведінки насильника.

Ключові слова: інцест; жертва; неповнолітній; перверсї; кримінальне правопорушення; механізм кримінально протиправної поведінки; сексуальне насильство.

Постановка проблеми. У сучасній Україні інцест - достатньо розповсюджене, хоч $\mathrm{i}$ латентне явище, оскільки більшість його «прибічників» (якщо мова йде про добровільну форму) або жертв (у разі сексуального насильства) не бажають розголошувати свою проблему на широкий загал. Звичайно, коли йдеться про інцестуальні стосунки, то охоплюється значна кількість родичів, які вступають у нездоровий статевий контакт. При цьому найнебезпечніша, найбільш кримінальна його форма - насильницькі сексуальні стосунки 3 неповнолітніми - залишається поза увагою, що призводить до зростання

(C) Тіточка Тетяна Ігорівна, 2021 
чисельності подібних випадків та створення у правопорушників хибного уявлення про безкарність та вседозволеність. На нашу думку, першопричиною будь-якого кримінального правопорушення, у тому числі й проти статевої свободи та статевої недоторканності, $є$ апріорі його суб'єкт. Однак неправильним буде не визнати, що основним детермінантом суспільно небезпечної поведінки часто стає іï жертва. Особливої актуальності ця теза набуває в контексті насильницького інцесту щодо підлітків. Отже, ураховуючи викладене вище, вважаємо за доцільне більш детально розглянути роль неповнолітньої жертви в механізмі перверсивної кримінально протиправної поведінки правопорушника.

Аналіз останніх досліджень і публікацій. Дослідженню особливостей сексуального насильства приділяли увагу такі вчені, як I. О. Бандурка, I. Бретертон, О. I. Бугера, Д. О. Гниліцька, А. О. Джужа, М. О. Ковальова, С. С. Косенко, Л. Г. Козлюк, Л. В. Левицька, Т. Д. Лисько, А. С. Лукаш, Л. М. Ларченко, І. МакКрорі, О. Ю. Мошицька, С. П. Репецький, О. В. Синєокий, М. О. Семикіна, О. С. Рябчук, Е. Уотерс, С. В. Чмут, О. Б. Шигоніна, Т. Г. Шувалова та інші.

Метою цієї статті $є$ визначення ролі неповнолітньої жертви в механізмі перверсивної кримінально протиправної поведінки.

Виклад основного матеріалу. Механізм дії факторів, що впливають на механізм злочинної поведінки особи, вітчизняні автори (О. М. Джужа, В. В. Василевич, А. М. Кирилюк) визначають умовно за такою схемою: а) спотворена система цінностей, гіпертрофовані потреби та викривлені ціннісні орієнтації окремих категорій громадян (або вакуум у системі цінностей) приводять у дію механізми, що руйнують систему соціальних інститутів, призводять до заміни соціальних норм «псевдонормами», порушують соціальні відносини у сфері правопорядку; б) у свою чергу, завдяки неефективності, деформації соціальних норм, які повинні регулювати процеси боротьби зі злочинністю, відокремленості останніх від конкретних кримінальних реалій, нестабільності, невизначеності, послабленості ïх фактичного застосування (що спричинюе безкарність, безвідповідальність правопорушників), порушенні зв'язку між елементами системи правового регулювання, спрацьовує механізм деформації та викривлення системи соціальних цінностей у свідомості певної частини громадян, а також у системі функціонування державних і громадських інститутів, призначених протидіяти злочинності [1, с. 66-67]. Перверсивна поведінка свідчить насамперед про втрату особою моральних цінностей та викривлення адекватного світосприйняття, що відбувається внаслідок певних психічних / психологічних відхилень. Перверсія не завжди стає першопричиною кримінально протиправної поведінки та за своєю сутністю є лише неадекватним, збоченим уявленням про статеві взаємовідносини. Однак окремі види сексуальних відхилень вимагають від особи вчинення протиправних дій, які дозволять їй отримати статеве збудження та його логічний фінал. У цьому контексті мова йде про педофілію (у т. ч. інцестного типу), некрофілію, примушування до вступу у статеві відносини (згвалтування, сексуальне насильство тощо). Саме тому першочергова роль жертви в механізмі перверсивної протиправної поведінки достатньо банальна - формальна відповідність потребам правопорушника за фізіологічними ознаками (стать, вік, зовнішність тощо).

Механізм дії факторів, що впливають і на механізм злочинної поведінки особи, згадані вище вітчизняні автори також визначають як: ...в) аналогічно деформації та дисфункції соціальних інститутів щодо забезпечення безпеки та організації законослухняної поведінки громадян i підтримання громадського порядку, здійснення соціального контролю спотворюють механізми соціальної напруженості та конфліктних ситуацій, спричиняють заміну державних інституцій неформальними, у т. ч. злочинними, засобами, негативно впливають на свідомість, нормативно-правову систему та деформують суспільні відносини у вигляді кримінальних явищ та процесів; г) деформовані соціальні відносини можуть, у свою чергу, бути дієвими механізмами як у вигляді початкових етапів, так і кінцевої ланки викривлення системи ціннісних орієнтацій громадян, порушень системи функціонування соціальних інститутів, дефектів та дисфункцій у правозастосовній діяльності судових та 
правоохоронних органів, що призводять до заміни орієнтацій, збільшення кількості конфліктів (у т. ч. пов'язаних із злочинами), підміни норм «тіньовою нормотворчістю» та неформальними зв'язками (корупцією) і втрати соціального контролю за злочинністю [1, с. 66-67]. Механізм учинення злочину є сукупністю фактів та елементів, що відбуваються послідовно. За таких умов розвиток причинних зв'язків взаємодіє з двома іншими компонентами будь-якої форми поведінки: а) особою злочинця; б) зовнішнім соціальним середовищем, у якому перебуває суб'єкт. У сукупності ці зв'язки та компоненти й утворюють генезис злочину [1, с. 66-67]. Тому можна стверджувати, що для реалізації протиправного умислу на вчинення насильницького інцесту щодо неповнолітнього необхідно: 1) особа, яка страждає на певні сексуальні відхилення (перверсії), а також не має остаточно сформованої системи цінностей та не наділена моральними якостями, здатними попередити девіантну поведінку; 2) неповнолітній, котрий через свої фізіологічні, психологічні або поведінкові особливості відповідає потребам правопорушника; 3) обстановка, яка сприяє та спрощує вчинення сексуального насильства.

Учені слушно зауважують, що саме діти володіють підвищеною віктимною схильністю до вчинення щодо них сексуального насильства, яка обумовлюється комплексом особистісних якостей. На думку О. М. Гуміна, ці якості умовно можна поділити на три групи: психологічні - особистісна незрілість, підпорядкованість авторитету дорослого, довірливість, нездатність повно, всебічно оцінити характер передкримінальної ситуації, неспроможність прогнозувати наслідки своїх дій, а також дій інших осіб, що поєднується з цікавістю та жагою до пригод, невмінням підлаштовуватися до нових умов, безпорадністю у складних ситуаціях, необізнаністю у сфері статевих стосунків; соціальні - соціально-педагогічна занедбаність, відсутність належного контролю з боку батьків та оточення дитини; біофізичні - рання або занадто рання сексуальність, фізична слабкість дітей, пов'язана з неможливістю фізичного опору сексуальному злочинцю [2, с. 132]. Г.Б. Дерягін виокремлює особливий вид віктимності - сексуальну віктимність, а жертв сексуального насильства поділяє на такі групи: 1) особи, яким притаманна особистісна сексуальна віктимність, - сексуальні девіанти 3 наявністю або відсутністю відхиленої соціальної поведінки; 2) особи, яким притаманна рольова сексуальна віктимність, - особи без вираженої сексуальної девіантності з високим соціоекономічним статусом, мешканці соціального «дна», діти, безпорадні особи, випадкові жертви-фетиші; 3) особи, яким притаманна ситуативна сексуальна віктимність, - ті, хто випадково опинився у раптовій віктимно несприятливій (криміногенній) ситуації [3, с. 237]. Убачаємо доцільним погодитися з позицією вченого. Про місце неповнолітньої жертви в механізмі протиправної поведінки йдеться лише тоді, коли дитина знаходиться у віці, що дозволяє ӥй хоча б частково оцінювати ситуацію. Тільки в такому разі можна визначити, що саме спровокувало суб'єкта: активна, агресивна / провокуюча чи зваблююча поведінка жертви; іiі беззахисність та пасивність, нездатність чинити опір або, навпаки, повне розуміння протиправності діяння та бажання припинити його. Коли жертвою є маленька дитина (що, на жаль, не є на сьогодні рідкісним явищем) або підліток, який через свої інтелектуальні відхилення не здатний оцінити ситуацію, на нашу думку, недоцільно говорити про ії фактичну роль у механізмі протиправної поведінки.

Ю. В. Антонян також здійснює типологію жертв сексуальних злочинів за характером їхньої поведінки, а саме: 1) поведінка яких має провокуючий характер, що переважно має вияв у встановленні контакту із зовсім незнайомими або малознайомими людьми, у відвідуванні їхнього житла або усамітнення з ними в інших затишних місцях, у спільному вживанні спиртних напоїв, некритичному сприйманні відкритих бажань майбутніх гвалтівників, у демонстрації некритичного ставлення до ймовірного сексуального зближення. Показник потерпілих 3 такою поведінкою сягає 10-15\% від загальної кількості жертв сексуального насильства; 2) поведінка яких не є провокуючою, однак об'єктивно обумовлює вчинення злочину. Це найчастіше необережні вчинки, наприклад поява жертви в темному місці, де існує велика вірогідність нападу на неї. Потерпілі з такою поведінкою становлять 35-40 \%; 3) поведінка яких може бути розцінена як позитивна або нейтральна. У таких випадках майбутні 
потерпілі не могли передбачити те, що вони можуть стати жертвою насильства. До них передусім належать діти та люди літнього віку. Ця категорія жертв становить 45-60 \% серед усіх потерпілих від насильників [4, с. 167]. Що ж стосується інцесту, то необхідно звернути увагу на те, що роль неповнолітньої жертви часто провокуюча, особливо, коли мова йде про стосунки між батьком та донькою. Дитина не завжди допускає думку про те, що надмірна сексуально-агресивна поведінка, яка виражається в демонструванні оголених частин тіла, жестикуляції тощо може викликати в рідного батька прагнення вчинити щодо неї протиправний насильницький акт. Саме в цьому контексті можна говорити про перверсивну поведінку суб'єкта кримінального правопорушення, котра обумовлена тим, що особа відчуває сексуальний потяг до власної дитини. Цікавим також $є$ і випадок, коли такі взаємовідносини $є$ добровільними та підліток сам прагне вступити у статевий контакт з одним зі своїх батьків. Для останнього така поведінка $є$ і де-факто, і де-юре кримінально караною, оскільки чинне кримінальне законодавство передбачає відповідальність за статеві зносини з особою, яка не досягла шістнадцятирічного віку, незважаючи на взаємну згоду партнерів. До того ж ч. 2 ст. 155 Кримінального кодексу України (протиправні дії, вчинені близькими родичами або членами сім'ї, особою, на яку покладено обов'язки щодо виховання потерпілого або піклування про нього, або якщо вони спричинили безплідність чи інші тяжкі наслідки) встановлює кваліфіковані межі покарання суб’єкта. Однак питання полягає в тому, яка роль у цій ситуації підлітка та чи можна його вважати жертвою. У загальному розумінні жертва - це особа, якій кримінальним правопорушенням завдано певну шкоду (фізичну, психологічну тощо). 3 погляду медицини статевий акт до настання статевої зрілості має серйозні загрози як фізичному (захворювання, що передаються статевим шляхом, небажані вагітності тощо), так і психічному (перверсії, депресії тощо) здоров'ю, у зв'язку з чим таке діяння було криміналізовано. Проте все це - лише умовні, імовірні негативні наслідки. Основною вимогою для підтвердження факту віктимної поведінки є усвідомлення особою завданої шкоди, іiі дійсне страждання від отриманих збитків. Коли підліток свідомо вступає у статевий контакт 3 повнолітньою особою, особливо близьким родичем, він фактично не є жертвою (навіть добровільною). Тому в такому разі стверджувати про роль у механізмі протиправної поведінки суб'єкта недоцільно, оскільки, якщо відійти від норм кримінального права та проаналізувати проблему з психологічної точки зору, у цій ситуації є дві особи з відхиленнями в сексуальній сфері, котрі на добровільній основі вирішили вступити у статевий контакт. Кримінальним законодавством це заборонено лише з огляду на можливі негативні наслідки для здоров'я особи, яка не досягла 16 років (16 років - вік статевої зрілості. Ураховуючи те, що після закінчення періоду статевого дозрівання особі фактично не може бути завдано шкоди (у разі добровільного акту), законодавець передбачив у нормі не вік повноліття, а вік статевої зрілості).

Ю. В. Александров неповнолітніх жертв статевих злочинів поділяє на такі види: 1) потерпілі, які своєю поведінкою ані до початку вчинення злочинних дій, ані під час їх здійснення жодною мірою не давали злочинцю підстави для виникнення в нього рішучості на вчинення злочину або його продовження; 2) потерпілі, які своєю поведінкою до початку вчинення злочинних діянь або під час їх здійснення дали злочинцю підстави для виникнення в нього рішучості на вчинення злочину або його продовження (так звана криміногенна поведінка потерпілих) [5, с. 61]. Беручи за основу цей розподіл, С. С. Косенко уточнила, що до першої групи належать неповнолітні жертви, які своєю поведінкою ні до початку, ні під час здійснення статевого насильства не давали злочинцю підстав для вчинення щодо них статевого злочину, їхня поведінка відповідає нормам моралі (це нейтральні потерпілі); а до другої групи - неповнолітні жертви, які своєю поведінкою до початку або під час здійснення статевого насильства давали злочинцю підстави для вчинення щодо них статевого злочину. Такі жертви можуть бути: активними та своїми діями сприяти вчиненню щодо них злочину (встановлення контакту 3 незнайомими людьми, відвідування їхнього житла тощо); некритичними, які вчасно не оцінюють життєву ситуацію, некритично сприймають бажання майбутніх гвалтівників та демонструють некритичне ставлення до ймовірного статевого 
зближення; провокуючими, які своєю поведінкою створюють об'єктивні підстави чи сприятливі умови для вчинення щодо них статевого злочину. Також автор зауважує, що інколи наявна так звана змішана поведінка дітей-жертв статевих злочинів. Вони не бажали вступати у статеві відносини зі злочинцем, але не чинили належного опору й не виявляли відмови на пропозиції злочинця. Таких жертв можна назвати пасивними [6, с. 18]. У цьому контексті цікавим є механізм взаємодії між особою, яка має перверсивну поведінку, та підлітком, стосовно якого вчиняється насильство. Зазначені вище вчені розглядали стандартні ситуації протиправних дій сексуального характеру щодо неповнолітніх. При цьому такі дії з боку кримінального правопорушника здебільшого обумовлені відсутністю іншої людини, здатної задовольнити його сексуальні потреби.

Сексуальні девіації не є хворобами, тому допомога лікаря таким людям потрібна тільки в тому разі, коли усвідомлення власних особливостей викликає в них психологічний дискомфорт. Проте межі й характеристики нормальних сексуальних проявів і поведінки точно не встановлено. У ситуаціях, що вимагають медичного втручання, людина втрачає контроль над своїми діями. Сексуальні переживання набувають характеру нездоланної болісної звички, нав'язливості, подібної до таких нездорових захоплень, як потяг до алкоголю чи наркотиків. У людей із сексуальними відхиленнями поступово зростає соціальна непристосованість, ізоляція від навколишнього світу. Вони можуть відчувати свою неповноцінність, неспроможність, внутрішнє роздвоєння переживань. Наростаючий і нерозв'язний конфлікт між способами статевого задоволення і загальноприйнятими сексуальними нормами в таких людей часто призводить до важких невротичних розладів, спроб самогубства. Однак у багатьох людей із різними варіантами психосексуального розвитку не виникає почуття провини і серйозних душевних переживань. У такому разі вони не потребують медичної допомоги. Але слід додати: окремим випадком є сексуальні відхилення, пов'язані із заподіянням фізичних чи моральних незручностей іншим людям без їхньої згоди. Подібна поведінка регулюється правовими нормами. У широкому сенсі сексуальним відхиленням уважають сексуальну поведінку, що відрізняється від прийнятих у певному суспільстві норм. За конкретним сексуальним злочином на психологічному рівні приховується неусвідомлене прагнення суб'єкта стати таким, яким йому хотілося б себе бачити, але яким він не $є$. В іншому випадку, коли злочин має захисно-компенсаторний характер, суб'єкт нібито захищає таким своєрідним способом наявні уявлення про себе 3 метою недопущення заниження самосприйняття [7, с. 130]. Варто звернути увагу, що в сучасних умовах погляди на нормальну та здорову статеву поведінку значно змінилися, як і реакція держави. Це досить яскраво ілюструє історичний процес еволюції кримінально-правової заборони. Так, наприклад, ще в минулих століттях одностатеві контакти каралися відповідно до норм кримінального законодавства незалежно від волевиявлення особи. Уже сьогодні вони повністю дозволені та визнані Всесвітньою організацією охорони здоров'я такими, що не пов'язані з психічними відхиленнями (що підтверджується виключенням гомосексуалізму 3 Міжнародної статистичної класифікації хвороб та проблем, пов'язаних зі здоров'ям). Проте більшість психіатрів продовжує співвідносити гомосексуалізм із девіантною поведінкою. Слушно зауважити, що аналогічний зв'язок простежується і між ювенальною гомосексуальністю та віктимністю.

До того ж необхідно зазначити й про інші важливі аспекти внутрішньої детермінації насильницької сексуальної поведінки. Їй часто сприяє сформоване нерідко цинічне уявлення про жінок, негативне та презирливе ставлення до їхньої особистої волі, гідності, статевої недоторканності. Для сексуального злочинця цінність жінки досить велика, але водночас надзвичайно низька ії статева недоторканність. Чим глибші та більш травматичні переживання в сексуальній сфері й міжстатевих відносинах, чим менше вони усвідомлюються, тим стабільніші установки на заперечення статевої недоторканності жінки, тим вища ймовірність учинення сексуальних злочинів, у тому числі повторних. Усі ці риси морально-психологічної характеристики особи сексуального злочинця виникають не відразу. Навпаки, вони формуються, розвиваються і закріплюються 3 перших років життя індивіда. Тому 
згвалтування, як і всі інші навмисні злочини, не можуть бути випадковими. Насильницька сексуальна поведінка внутрішньо закономірна, підтверджена всім ходом життя, $є$ ніби його підсумком. Зовнішні обставини, зокрема неналежна поведінка жертви, сп'яніння злочинця, виконують лише роль умов. Це стосується і тих випадків групових злочинів, коли сексуальний злочинець діє під впливом співучасників: він потрапляє у психологічну залежність від них, від сформованої ситуації. I якщо він учинив такі дії, це для нього закономірно [7, с. 131]. Взаємозв'язок правопорушника з неповнолітньою жертвою прямо пропорційно залежить від двох чинників: попередній досвід сексуальних взаємовідносин (часто - травматичний) та поведінкова реакція дитини. Крім того, очевидним є й обрання статі та віку жертви, що обумовлюється потребами (хворобливим станом тощо) девіанта.

Діти здебільшого стають жертвами насильства в батьківській родині, процес їх гендерної соціалізації відбувається в несприятливих, а іноді навіть у небезпечних умовах. За результатами психологічних досліджень установлено, що діти - жертви жорстокого поводження і зневаги - мають цілий набір специфічних психологічних рис, головною особливістю яких $є$ їхня амбівалентність (наявність та взаємодія одночасно двох антагоністичних, протилежних почуттів, думок або бажань, наприклад любов та ненависть) [8] як реакція на суперечливі вимоги батьків. Підлітки, які зазнали зловживання, не сприймають батьків як референтну групу, характеризуються поєднанням імпульсивності та довготерпіння; підозрілістю i недовірливістю 3 одночасною ірраціональною вірою в можливість поліпшення внутрішньої родинної ситуації. Вони емоційно залежні і почуваються винними за інциденти насильства, самотність, ізольованість, страх перед майбутнім і впевненість у відсутності перспектив, мають занижену самооцінку. У них спостерігається сплутаність ідентичності, розмитість, нечіткість Я-концепції, конформність, схильність до прийняття ролей, які нав'язуються оточенням, нерозвинене уявлення про потреби власного «Я». Підлітки, які живуть в умовах сімейного насильства, демонструють схильність до депресій, високий рівень схильності до стресу; явні депресивні та/або істеричні симптоми, симптоми деперсоналізації і реактивних розладів; вони часто пропускають шкільні заняття через нездужання психосоматичного характеру. Такі підлітки характеризуються високим ступенем ризику алкоголізації i наркотизації, передделінквентною i делінквентною поведінкою, зухвалою сексуальною поведінкою, дромоманією (потягом до втеч 3 дому, поневірянь і зміни місць) [9, с. 57]. За даними цього дослідження, у багатьох дітей - жертв насильства в сім'ї - були зафіксовані ознаки різного рівня відставання в інтелектуальному $(16,4 \%)$, фізичному $(11,5 \%)$, психічному розвитку (6\%), зміни особистості дитини за кримінальним типом 3 бродяжництвом і крадіжками (3\%) та за примітивним типом 3 бродяжництвом і жебрацтвом (6\%). Навіть у проаналізованих цивільних справах (про розірвання шлюбу, про позбавлення батьківських прав) указувалося на такі характеристики дітей-жертв сімейного насильства: «дитина вкрай налякана та не дозволяє до себе підходити, лякається всіх, часто плаче» [10]; «у хлопчика низький рівень розвитку, на заняттях неуважний, слабко розвинуто логічне мислення» [11]; «у дітей було виявлено обмороження кінцівок, вони виснажені, потребують лікування» [12]. Ще однією формою деструктивного впливу сімейного насильства на формування особистості дитини $є$ споглядання за його постійними проявами, яке дослідники вважають настільки ж травматичним, як і безпосереднє переживання насильства [13, с. 114]. Перебування дитини в несприятливій обстановці формує 3 неї не тільки жертву, а й часто кримінального правопорушника. Споглядання насильства має лише два наслідки: дитина стає або емоційно лабільною, або агресивною.

Група британських учених із Лондонського університетського коледжу та Центру Анни Фрейд провела дослідження 20 мешканців Лондона у віці близько 12 років, які стали об'єктами або свідками домашнього насильства. Активність різних ділянок мозку дітей вивчалася за допомогою функціональної магнітно-резонансної томографії під час показу чоловічих та жіночих облич $з$ різними виразами - сумними, задуманими й агресивними. Показники мозкової активності порівнювалися з контрольною групою з 23 дітей, що живуть у спокійній домашній обстановці. Мозок дітей з неблагополучних сімей реагував на зображення облич, 
що виражають агресію, інакше, ніж мозок дітей, яких не торкнулося домашнє насильство. Томограф зафіксував у таких дітей підвищену активність у передній частині острівної частини й мигдалині - двох ділянках головного мозку, пов'язаних із виявленням зовнішньої загрози і реакцією на неї. Попередні дослідження засвідчили аналогічну аномальну активність у головному мозку солдатів, які брали участь у бойових діях. Як припустили автори дослідження, побачені сцени жорстокості й насильства налаштовують мозок на надмірну реакцію на потенційну загрозу. За твердженням лікаря Імони МакКрорі, керівника цієї групи вчених, подібна реакція дитячого мозку є природною адаптивною відповіддю на небезпечну ситуацію. Однак у більш дорослому віці в таких дітей підвищується ризик різних психічних захворювань, зокрема тривожних станів, неврозів, депресії [14]. Якщо мова йде про домашнє насильство, особливо сексуальне, необхідно звернути увагу на те, що в цьому контексті роль неповнолітньої жертви в механізмі перверсивної поведінки дуже часто обумовлюється притаманними для цієї вікової категорії протестними вчинками, які викликають агресію в насильника.

У віктимологічному розумінні до основних елементів механізму злочинної поведінки належать: особистісні властивості, мотивація, конкретна обстановка, прийняття рішення про вчинення злочину і сам процес його вчинення (акт поведінки). Перераховані елементи можна поділити на дві групи: складові психологічної структури поведінки (мотивація і прийняття рішення про вчинення акту поведінки) та продукти взаємодії об'єктивного й суб' єктивного в поведінці (особистісні властивості, конкретна обстановка й акт поведінки). Що стосується взаємодії згаданих елементів механізму злочинної поведінки, то в більшості кримінологічних досліджень головна роль у структурі системи, що вивчається, відведена мотивації, яка вважається внутрішнім стрижнем генезису цього механізму. Водночас мотивація розглядається як процес і як сукупність мотивуючих факторів. Як процес вона є спонуканням до конкретної поведінки, у якій беруть участь такі утворення, як потреби, ціннісні орієнтації, особисті властивості індивіда, емоційні переживання та ін., що формують у динаміці і взаємозв'язку певні стадії процесу мотивації. Якщо з певних причин усвідомлення потреб, цілеутворення, вибір конкретного способу здійснення запланованого тощо стають неможливими, то діяльність не починається, а отже й мотив залишається в потенційному стані. Інакше кажучи, якщо не буде завершений процес мотивації і сформоване спонукання до конкретної поведінки, то оперативні мотиваційні настанови, наявні в особи, так і не будуть реалізовані [15, с. 111]. Кримінально протиправна поведінка особи, яка вчиняє щодо неповнолітнього сексуальне кримінальне правопорушення, переважно мотивована фізіологічною та психічною потребою задовольнити статевий потяг. Більшість таких протиправних діянь здійснюються у стані алкогольного сп'яніння, котре полегшує насильнику процес усвідомлення свого протиприродного бажання, остаточно формуючи виникнення прямого умислу. Якщо мова йде про психічнохвору людину, то в неї цей умисел сформований та повторюваний (багатоактний). Жертва $є$ центром мотивації, формуючи та обумовлюючи іiі реалізацію. Отже, неповнолітній віктим інтегрований у суб'єктивний компонент поведінки насильника.

До того ж необхідно пам'ятати, що результатом процесу мотивації є не сама діяльність, а деяке психічне утворення, що відображає і потреби, і мотиви, і цілі, і способи їх досягнення, тобто всі основні елементи, що безпосередньо ініціюють діяльність і входять до структури процесу мотивації. Отже, найбільш вдалим терміном для позначення результату процесу мотивації $\epsilon$ «спонукання», що розуміють як психічне утворення, сформоване в процесі мотивації, яке відображає його основні елементи та безпосередньо ініціює конкретну діяльність індивіда, підтримуючи ії під час здійснення. Зміст спонукання визначається змістом потреби, що є джерелом активності людини, а його характер повністю залежить від характеру мотиву, що орієнтує. Мотив $є$ центральною ланкою мотивації поведінки й бере участь у ній доти, доки не наблизиться настільки, наскільки дозволять умови ситуації, або цільовий стан не перестане загрозливо віддалятися, або умови, що змінилися, не зроблять інший мотив більш вагомим, як наслідок, останній актуалізується і стане домінуючим [15]. Мотивація пояснює 
цілеспрямованість поведінки, що особливо помітна, коли та сама людина намагається досягти тієї самої мети в різний спосіб. Якщо ж при цьому особа натрапляє на перешкоду, то обирає інший шлях. Таким чином, суть мотивації полягає у виборі між різними можливостями. Прийняття рішення про вчинення акту поведінки виконує прогностичну та спонукальну функції, що мають вирішальний вплив на обрану модель поведінки. Об'єктивні соціальні умови формування особистості, до яких належать спосіб життя і мікросередовище (соціальні групи), є основоположним чинником у структуруванні рис характеру, світогляду, навичок та іншого досвіду, які, зрештою, визначають структуру особистості та іï зміст. Конкретна обстановка включає специфіку взаємодії особистості й соціального середовища та особливості суб'єктивного відображення об'єктивної дійсності [15, с. 111]. Звичайно, доцільно зазначити, що механізм перверсивної поведінки насильника $\epsilon$ стійким комплексом взаємозалежних елементів суб'єктивних та об'єктивних чинників. Однак, коли йдеться про останні, роль неповнолітньої жертви полягає лише в учиненні дій, які спрощують реалізацію правопорушником кримінально протиправного умислу.

Висновки. Отже, на сьогодні віктимологічна наука не має ефективного комплексу заходів та засобів протидії кримінально небезпечній сексуальній поведінці. До того ж кримінологія також не може запропонувати дієву стратегію боротьби з такими кримінальними правопорушеннями. Насправді ж учені вже давно зробили єдиний правильний висновок, що жодне кримінально протиправне діяння не можливе без активної участі та сприяння обох сторін - правопорушника та потерпілого. Перверсивна кримінально протиправна поведінка дещо відрізняється від аналогічних за окремими ознаками: 1) обмеження кола потерпілих відповідно до сексуальних переваг насильника; 2) визначений перелік способів учинення суспільно небезпечного діяння; 3) наявність лише прямого умислу на вчинення правопорушення. Неповнолітня жертва в механізмі перверсивної кримінально протиправної поведінки відтворює суб' єктивну сторону насильника, відіграючи ключову роль у формуванні мотивації, а також певним чином сприяє іiї реалізації шляхом створення умов, які допомагають правопорушнику реалізувати свій умисел.

\section{Список використаних джерел}

1. Джужа О., Василевич В., Кирилюк А. Щодо механізму злочинної поведінки. Право Украӥни. 2005. № 6. С. 66-70.

2. Гумін О. М. Кримінальна насильницька поведінка проти особи : монографія. Львів : ЛьвДУВС, 2009. 360 с.

3. Дерягин Г.Б. Криминальная сексология : курс лекций для юридических факультетов. М., 2008. 552 с.

4. Антонян Ю. М., Ткаченко А. А. Сексуальные преступления. Чикатило и другие. М. : Фирма «Амальтея», 1993. 320 с.

5. Александров Ю. В. Половые преступления: преступники и потерпевшие : учеб.практ. пособие. К. : КВШ МВД СССР, 1975. 91 с.

6. Косенко С. С. Віктимологічна профілактика статевих злочинів щодо неповнолітніх : автореф. дис. ... канд. пед. наук : 12.00.08. К., 2004. 21 с.

7. Тичина Д. М. Біологічні та психологічні детермінанти сексуальності. Правовий часопис Донбасу. 2018. № 2. С. 129-134.

8. Амбівалентність. URL: http://uk.wikipedia.org/wiki/Амбівалентність (дата звернення: 21.04.2021).

9. Кочемировская Е. А. Психологические особенности понимания и переживания насилия младшими подростками и юношами (психосемантический подход) : дис. ... канд. психол. наук : 19.00.01. Харьков, 2001. 248 с.

10. Ухвала Хмільницького міськрайонного суду Вінницької області від 22.03.2013 : архівна справа № 149/567/13-ц. URL: http://reyestr.court.gov.ua/Review/30162807 (дата звернення: 21.04.2021). 
11. Ухвала Василівського районного суду Запорізької області від 22.03.2013 : архівна справа № 2/802/656/2012. URL: http://reyestr.court.gov.ua/Review/24985098 (дата звернення: 21.04.2021).

12. Рішення Тиврівського районного суду Вінницької області від 20.02.2012 : архівна справа № 2/223/511/2012. URL: http://reyestr.court.gov.ua/Review/21734313 (дата звернення: 21.04.2021).

13. Блага А. Б. Насильство в сім’ї (кримінологічний аналіз і запобігання) : монографія. Х. : ФОП Макаренко, 2014. 360 с.

14. Психологи: Домашнє насильство i війна однаково впливають на мозок людини. URL: http://ua.korrespondent.net/tech/science/1291195/print (дата звернення: 21.04.2021).

15. Бандурка О. М., Литвинов О. М. Механізм злочинної поведінки. Вісник Кримінологічної асоціачії України. 2016. № 3 (14). С. 110-119.

\section{References}

1. Dzhuzha, O., Vasylevych, V., Kyryliuk, A. (2005). Shchodo mekhanizmu zlochynnoi povedinky [Regarding a mechanism for criminal behavior]. Pravo Ukrainy. № 6. S. 66-70 [in Ukrainian].

2. Humin, O. M. (2009). Kryminalna nasylnytska povedinka proty osoby : monohrafiia [Criminal violent behavior against a person : monograph]. Lviv : LvDUVS, 360 s. [in Ukrainian].

3. Deryagin, G. B. (2008). Kriminal'naya seksologiya: kurs lekcij dlya yuridicheskih fakul'tetov [Criminal Sexology: course of lectures for law faculties]. M. 552 s. [in Russian].

4. Antonyan, YU. M., Tkachenko, A. A. (1993). Seksual'nye prestupleniya. CHikatilo i drugie [Sexual crimes. Chicatilo and others]. M. : Firma «Amal'teya», 320 s. [in Russian].

5. Aleksandrov, YU. V. (1975). Polovye prestupleniya: prestupniki i poterpevshie : ucheb.-prakt. posobie [Sexual crimes: criminals and victims: educational and practical allowance]. K. : KVSH MVD SSSR. 91 s. [in Russian].

6. Kosenko, S. S. (2004). Viktymolohichna profilaktyka statevykh zlochyniv shchodo nepovnolitnikh : avtoref. dys. ... kand. ped. nauk : 12.00.08 [Victimologic prevention of sex crimes for minors: the dissertation of the candidate of pedagogical sciences: 12.00.08]. K. $21 \mathrm{~s}$. [in Ukrainian].

7. Tychyna, D. M. (2018). Biolohichni ta psykholohichni determinanty seksualnosti [Biological and psychological determinants of sexuality]. Pravovyi chasopys Donbasu. № 2. S. 129134 [in Ukrainian].

8. Ambivalentnist [Ambivalence]. URL: http://uk.wikipedia.org/wiki/Амбівалентність (data zvernennia: 21.04.2021) [in Ukrainian].

9. Kochemirovskaya, E. A. (2001). Psihologicheskie osobennosti ponimaniya i perezhivaniya nasiliya mladshimi podrostkami i yunoshami (psihosemanticheskij podhod) : dis. kand. psihol. nauk : 19.00.01 [Psychological features of understanding and experiences of violence with junior teenagers and young men (psychosemantic approach) : dis. ... cand. psychologist. sciences : 19.00.01]. Har'kov. 248 s. [in Russian].

10. Ukhvala Khmilnytskoho miskraionnoho sudu Vinnytskoi oblasti vid 22.03.2013 : arkhivna sprava № 149/567/13-ts [The ruling of the Khmilnitsky City Court of Vinnytsia region from 22.03.2013 : Archival case № 149/567/13ts]. URL: http://reyestr.court.gov.ua/Review/30162807 (data zvernennia: 21.04.2021) [in Ukrainian].

11. Ukhvala Vasylivskoho raionnoho sudu Zaporizkoi oblasti vid 22.03.2013 : arkhivna sprava № 2/802/656/2012 [The decree of the Vasiliv district court of Zaporozhye region from 03.22.2013 : Archival case № 2/802/656/2012]. URL: http://reyestr.court.gov.ua/Review/24985098 [in Ukrainian].

12. Rishennia Tyvrivskoho raionnoho sudu Vinnytskoi oblasti vid 20.02.2012 : arkhivna sprava № 2/223/511/2012 [The decision of the Tyvrivsky District Court of Vinnytsia region from 
02.2012 : Archival case № 2/223/511/2012]. URL: http://reyestr.court.gov.ua/Review/21734313 (data zvernennia: 21.04.2021) [in Ukrainian].

13. Blaha, A. B. (2014). Nasylstvo v simi (kryminolohichnyi analiz i zapobihannia) : monohrafiia [Family violence (criminological analysis and prevention) : monograph]. Kh. : FOP Makarenko. 360 s. [in Ukrainian].

14. Psykholohy: Domashnie nasylstvo i viina odnakovo vplyvaiut na mozok liudyny [Psychologists: domestic violence and war equally affect the brain of a person]. URL: http://ua.korrespondent.net/tech/science/1291195/print (data zvernennia: 21.04.2021) [in Ukrainian].

15. Bandurka, O. M., Lytvynov, O. M. (2016). Mekhanizm zlochynnoi povedinky [A mechanism of criminal behavior]. Visnyk Kryminolohichnoi asotsiatsii Ukrainy. № 3 (14). S. 110119 [in Ukrainian].

Titochka Tetiana,

$\mathrm{PhD}$ in Law

(Donetsk State University of Internal Affairs, Mariupol)

ORCID: https://orcid.org/0000-0002-5924-614X

\section{THE ROLE OF A JUVENILE VICTIM IN THE MECHANISM OF PERSONAL CRIMINAL ILLEGAL BEHAVIOR}

In the article the author considers the role of a minor victim in the mechanism of perverse criminal illegal behavior. It is pointed out that perverse behavior a priori indicates, first of all, the loss of a person's moral values and distortion of adequate worldview, which occurs due to certain mental / psychological disorders. Perversion does not always become the root cause of criminally illegal behavior and is essentially an inadequate, perverted notion of sexual intercourse. However, certain types of sexual deviations require a person to commit illegal acts that will allow him to obtain sexual arousal and its logical ending. In this context, we are talking about pedophilia (including incest), necrophilia, forced sexual intercourse (rape, sexual violence, etc.). That is why the primary role of the victim in the mechanism of perverse illegal behavior is quite banal-formal compliance with the needs of the offender on physiological grounds (sex, age, appearance, etc.). Emphasis is placed on the fact that in order to commit unlawful intent to commit violent incest against a minor, it is necessary to: 1) a person suffering from a certain kind of sexual deviations (perversion), and also does not have a finally formed system of values and is not endowed with moral qualities capable of warning deviant behavior; 2) a juvenile who, due to his physiological, psychological or behavioral characteristics, meets the needs of the offender; 3) an environment that promotes and facilitates the commission of sexual violence. The author argues that the criminally illegal behavior of a person who commits a sexual criminal offense against a minor is most often motivated by a physiological and mental need to satisfy sexual desire. Most of these illegal acts are committed in a state of intoxication, which facilitates the perpetrator's process of realizing his unnatural desire, ultimately forming the emergence of direct intent. If we are talking about a priori mentally ill person, then this intention is formed and repeated in him (multi-act). The victim is the center of motivation, shaping and determining its implementation. Thus, the juvenile victim is integrated into the subjective component of the abuser's behavior.

Key words: incest; victim; juvenile; perversions; criminal offense; mechanism of criminally illegal behavior; sexual violence.

Надіслано до редколегії 13.05.2021 Рекомендовано до публікації 17.05.2021 


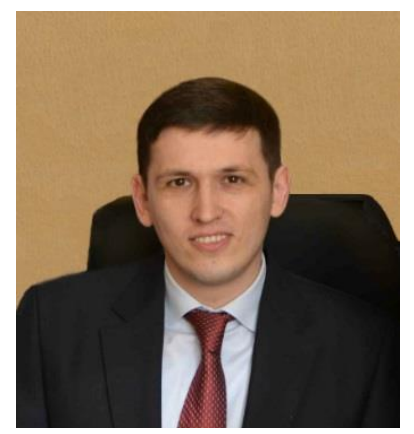

\title{
Щербіна Артем Валентинович,
} аспірант

(Донецький державний університет внутрішніх справ, м. Маріуполь)

ORCID: https://orcid.org/0000-0001-8600-1829

\section{ГЕНЕЗА ТА ПЕРЕДУМОВИ РОЗВИТКУ АВТОМАТИЗОВАНОЇ СИСТЕМИ ДОКУМЕНТООБІГУ СУДУ В УКРАЇНІ}

\begin{abstract}
У статті розглядаються особливості розвитку автоматизованої системи документообігу суду в Україні. Зазначається, що процес становлення досліджуваного феномену можна умовно поділити на кілька етапів. Звертається увага на те, щзо розвиток автоматизованої системи документообігу суду став одним із напрямів удосконалення процесу інформатизації та комп'ютеризачії діловодства в державі, підтвердженням стрімкої еволючії технічного прогресу. На сьогодні зазначена система надає можливість не тільки прискорити прочес роботи, а й дозволяє отримати швидкий доступ до необхідних документів, які знаходяться у вільному користуванні в інтернет-мережі. Однак саме спрощчення інформаційної взаємодії призвело до виникнення низки ситуацій, які становлять загрозу кримінологічній безпеці України, у зв'язку з чим у 2009 рочі було прийнято рішення про криміналізацію незаконного втручання в роботу автоматизованої системи документообігу суду. Захист інформації, яка належить судовій системі, є не менш важливим та може розглядатися як один із напрямів захисту нашої держави.
\end{abstract}

Ключові слова: інформачійна безпека; інтернет-мережа; кримінальне законодавство; кримінальне правопорушення; автоматизована система документообігу суду; діджиталізація.

Постановка проблеми. Історія кримінального законодавства починається майже одночасно з історією виникнення людства, а тому і їх розвиток відбувається синхронно та поетапно. Звичайно, це здебільшого стосується підходів до визнання того чи іншого діяння протиправним та кримінально караним, установлення меж кримінальної відповідальності тощо. Очевидним є той факт, що Особлива частина кримінального законодавства створена дійсно раніше, ніж Загальна, що обумовлено тривалим прогресом суспільства, а тому i, відповідно, тривалим визнанням необхідності структурованого та єдиного бачення схеми взаємодії з особою, яка вчинила суспільно небезпечне діяння. Більшість таких діянь уперше були визнані протиправними ще в давні часи та каралися згідно з тогочасним «законом». При цьому не можна залишити без уваги й те, що чинний Кримінальний кодекс України 2001 року (далі - КК України) має низку абсолютно нових кримінальних правопорушень, які з'явилися внаслідок зміни суспільного менталітету, технічного прогресу тощо. Одним із 
таких кримінальних правопорушень $\epsilon$ незаконне втручання в роботу автоматизованої системи документообігу суду, кримінальна відповідальність за яке передбачена ст. 376-1 КК України. Ураховуючи, що вказане діяння є абсолютно новим, уважаємо доцільним дослідити основні історичні передумови його виникнення та кримінально-правового захисту.

Аналіз останніх досліджень та публікацій. На сьогодні кримінальне правопорушення, передбачене ст. 376-1 КК України, залишається не достатньо дослідженим. Окремі аспекти висвітлено в працях таких учених, як В. І. Саранюк, В. А. Козак, О. В. Федорчук та ін.

Метою статті $є$ дослідження генези та передумов розвитку автоматизованої системи документообігу суду в Україні та визначення перспектив подальшого розвитку й удосконалення вітчизняного кримінального законодавства.

Виклад основного матеріалу. На нашу думку, початком криміналізації досліджуваного феномену є прагнення законодавця до захисту інформації та закріплення дефініції «інформаційна безпека», що було вдало реалізовано шляхом внесення до Конституції України ст. 17, у якій установлено, що захист суверенітету й територіальної цілісності України, забезпечення іiї економічної та інформаційної безпеки є найважливішими функціями держави, справою всього Українського народу [1]. Тому на конституційному рівні в державі було визнано пріоритетом забезпечення інформаційної безпеки. Варто зазначити, що на сьогодні підходи до вказаного поняття як в загальному, так і в кримінально-правовому сенсі $\epsilon$ не повністю однозначними, що можна пояснити неповноцінною узгодженістю положень відповідних нормативно-правових актів.

Так, у Законі України «Про Концепцію Національної програми інформатизації» від 4 лютого 1998 року вказано, що інформаційна безпека є невід’ємною частиною політичної, економічної, оборонної та інших складових національної безпеки. До об'єктів інформаційної безпеки цей закон відносить: інформаційні ресурси, канали інформаційного обміну й телекомунікації, механізми забезпечення функціонування телекомунікаційних систем і мереж та інші елементи інформаційної інфраструктури країни. Отже, інформаційна безпека в цьому нормативно-правовому акті розуміється як комплекс заходів, спрямованих на забезпечення захисту інформації від неправомірного витоку, перекручення, знищення тощо [2]. Зазначений нормативно-правовий акт визначає, що посягання на інформаційну безпеку $є$ передусім кримінально караним діянням з огляду на рівень суспільної небезпечності, котра вимірюється державними масштабами. При цьому не можна не вказати, що досліджуваний феномен захищається і суміжними галузями права.

Приблизно той самий зміст досліджуване поняття має і в Рішенні Ради голів урядів Співдружності Незалежних Держав (далі - СНД) про Концепцію інформаційної безпеки держав-учасниць Співдружності Незалежних Держав у військовій галузі. Хоча термін «інформаційна безпека» визначається в цьому документі як «стан захищеності інформаційного середовища суспільства, який забезпечує його формування, використання $\mathrm{i}$ розвиток в інтересах громадян, організацій, держави», але використовується як близький за змістом до поняття «захист інформації». Про це насамперед свідчить визначення системи забезпечення інформаційної безпеки, яка розуміється як сукупність правових, організаційних і технічних заходів, органів, сил, засобів та норм, спрямованих на попередження або істотне ускладнення заподіяння шкоди власнику інформації, а також перелік методів забезпечення інформаційної безпеки, який фактично є переліком методів забезпечення захисту інформації [3, с. 12]. Отже, з контексту стає очевидним, що законодавець, коли йдеться про інформаційну безпеку, акцентує увагу на необхідності залучати комплекс заходів та засобів, здатних сприяти захисту тісї чи іншої інформації.

В Указі Президента України «Про заходи щодо розвитку національної складової глобальної інформаційної мережі Інтернет та забезпечення широкого доступу до цісї мережі в Україні» від 31 липня 2000 року поняття інформаційної безпеки вже не обмежується тільки захистом інформаційного ресурсу. Так, до завдань щодо гарантування інформаційної безпеки держави належить недопущення поширення інформації, розповсюдження якої заборонено 
відповідно до законодавства. Отже, забезпечення інформаційної безпеки розуміється не тільки як захищеність інформаційного ресурсу, а й захищеність суспільства від розповсюдження «негативної» інформації (порнографія, пропаганда культу насильства та жорстокості тощо). Закон України «Про основи національної безпеки України» від 19 червня 2003 року використовує поняття «інформаційна безпека» у ще ширшому значенні. Про це свідчить зміст визначених у ньому загроз та напрямів державної політики в інформаційній сфері [3, с. 12]. Так, до загроз національній безпеці в інформаційній сфері Закон відносить: 1) прояви обмеження свободи слова та доступу громадян до інформації; 2) поширення через засоби масової інформації культу насильства, жорстокості, порнографії; 3) комп’ютерну злочинність та комп'ютерний тероризм; 4) розголошення інформації, яка становить державну та іншу передбачену законом таємницю, а також конфіденційної інформації, що $є$ власністю держави або спрямована на забезпечення потреб та національних інтересів суспільства і держави; 5) намагання маніпулювати суспільною свідомістю, зокрема шляхом поширення недостовірної, неповної або упередженої інформації. Основними ж напрямами державної політики з питань національної безпеки Закон визначає: 1) забезпечення інформаційного суверенітету України; 2) удосконалення державного регулювання розвитку інформаційної сфери шляхом створення нормативно-правових та економічних передумов для розвитку національної інформаційної інфраструктури та ресурсів, впровадження новітніх технологій у цій сфері, наповнення внутрішнього та світового інформаційного простору достовірною інформацією про Україну; 3) активне залучення засобів масової інформації до боротьби 3 корупцією, зловживаннями службовим становищем, іншими явищами, які загрожують національній безпеці України; 4) забезпечення неухильного дотримання конституційного права громадян на свободу слова, доступу до інформації, недопущення неправомірного втручання органів державної влади, органів місцевого самоврядування, їх посадових осіб у діяльність засобів масової інформації, дискримінації в інформаційній сфері та переслідування журналістів за політичні позиції; 5) вжиття комплексних заходів щодо захисту національного інформаційного простору та протидії монополізації інформаційної сфери України [3, с. 13]. Не можна ігнорувати той факт, що на сьогодні інформація - це один із потужних засобів впливу на суспільство. Саме інформаційна війна часто призводить до всесвітніх колапсів та здійснює деструктивний вплив на політичну та економічну систему держави.

Логічним продовженням такого підходу законодавця $є$ визначення інформаційної безпеки, яке подано в Законі України «Про основні засади розвитку інформаційного суспільства в Україні на 2007-2015 роки» від 9 січня 2007 року: це «стан захищеності життєво важливих інтересів людини, суспільства і держави, при якому запобігається нанесення шкоди через: неповноту, невчасність та невірогідність інформації, що використовується; негативний інформаційний вплив; негативні наслідки застосування інформаційних технологій; несанкціоноване розповсюдження, використання і порушення цілісності, конфіденційності та доступності інформації». Таке тлумачення достатньо чітко фіксує відхід законодавця від вузького розуміння інформаційної безпеки як технічного захисту інформації, її визначення сформульоване як стан захищеності від загроз інформаційного та технологічного характеру [3, с. 14]. Підтримуємо запропоновану дефініцію, оскільки вона охоплює максимальну кількість варіантів посягання на інформаційну безпеку.

Указом Президента України № 514/2009 від 8 липня 2009 року було затверджено Доктрину інформаційної безпеки України. Як слушно зазначає О. Г. Братель, цей документ становить «сукупність офіційних поглядів на мету, функції, принципи та методи забезпечення національної безпеки України в інформаційній сфері» [4, с. 37]. Розглянемо детальніше його положення. По-перше, підкреслюється подвійне значення інформаційної безпеки: 1) як невід'ємної складової кожної зі сфер національної безпеки; 2) як самостійної сфери національної безпеки. По-друге, класифікація життєво важливих інтересів в інформаційній сфері здійснюється за суб'єктом, тобто доктриною виокремлюються інтереси особи, суспільства та держави. До інтересів особи в доктрині віднесено: забезпечення конституційних прав i свобод людини на збирання, зберігання, використання та 
розповсюдження інформації; недопущення несанкціонованого втручання у зміст, процеси обробки, передачі та використання персональних даних; захищеність від негативного інформаційно-психологічного впливу [3, с. 14]. Необхідно звернути увагу на те, що апріорі наша держава основною метою створення системи захисту інформації насамперед убачає реалізацію плану дій із забезпечення національної безпеки. Утім, на нашу думку, захист інформації, яка належить судовій системі, $є$ не менш важливим та може розглядатися як один із напрямів захисту нашої держави. Варто зазначити, що популяризація терміна «інформаційна безпека» почала відбуватися з розвитком засобів масової інформації (особливо інтернетмережі), переходом до автоматизації документообігу в Україні та загальної діджиталізації. Не можна ігнорувати той факт, що комп'ютеризація значно спрощує процес ведення тих чи інших справ, робить доступ до необхідних документів максимально швидким та зручним. Саме так український законодавець наближається до європеїзації, розбудовуючи державу та враховуючи інтереси іiі громадян.

У загальному сенсі інтереси суспільства полягають у збереженні та примноженні духовних, культурних і моральних цінностей українського народу; забезпеченні суспільнополітичної стабільності, міжетнічної та міжконфесійної злагоди; формуванні й розвитку демократичних інститутів громадянського суспільства. Тлумачення поняття «державні інтереси» сформульовано так: недопущення інформаційної залежності, інформаційної блокади України, інформаційної експансії з боку інших держав та міжнародних структур; ефективна взаємодія органів державної влади та інститутів громадянського суспільства під час формування, реалізації та коригування державної політики в інформаційній сфері; побудова та розвиток інформаційного суспільства; забезпечення економічного та науковотехнологічного розвитку України; формування позитивного іміджу України; інтеграція України у світовий інформаційний простір. По-третє, у доктрині визначено основні реальні й потенційні загрози інформаційній безпеці в певних сферах та основні напрями протидії їм. Таким чином, аналіз національного законодавства дає підстави стверджувати, що наявною $\epsilon$ тенденція до розширення змісту законодавчого визначення поняття «інформаційна безпека». 3 розвитком інформатизації суспільства та вдосконаленням нормативно-правового забезпечення цих процесів розуміння інформаційної безпеки на законодавчому рівні пройшло шлях від вузького, найпростішого ії визначення як технічного захисту інформації до складної розгалуженої системи [3, с. 15]. На нашу думку, 3 кримінально-правової точки зору інформаційну безпеку необхідно розуміти як сукупність кримінально-правових засобів та заходів, які створюють алгоритм активної протидї протиправному посяганню на права, свободи та законні інтереси фізичних і юридичних осіб, а також держави та суспільства в цілому шляхом нанесення шкоди через негативний інформаційний вплив (курсив мій. - А. Щ.). До того ж необхідно чітко усвідомити принципову різницю між інформаційною безпекою та безпекою інформації. На наш погляд, безпекою інформації є стан захисту тих чи іниих даних від несанкиіонованого доступу з метою внесення неправдивих та/або несвоєчасних відомостей (курсив мій. - А. Щ.). У межах досліджуваної ст. 376-1 чинного КК України, яка передбачає кримінальну відповідальність за незаконне втручання в роботу автоматизованої системи документообігу суду, доцільніше говорити про посягання саме на безпеку інформації. Варто також зазначити, що вказана стаття є новелою кримінального законодавства, яка стала логічним завершенням процесу прийняття низки нормативно-правових актів як 3 питань захисту інформації та інформаційної безпеки, так і вдосконалення роботи судової системи України.

Програмою інтеграції України до Свропейського Союзу (далі - Програма), схваленої Указом Президента № 1072/2000 від 14.09 .2000 p., було визначено пріоритетність співробітництва України з Європейським Союзом (далі - СС), зокрема і стосовно судової системи, та закріплено вирішення питання щодо запровадження в Україні системи органів адміністративної юстиції, у тому числі адміністративних судів, а також прийняття адміністративного процесуального законодавства. Серед іншого, Програма передбачала здійснення Україною дій для поліпшення доступу до інформації стосовно рішень судів [5]. 
Якщо починати розгляд законодавчої ієрархії зверху, то можна помітити основні засади такого інформаційного забезпечення як будь-яких державних установ, так й адміністративного судочинства в Конституції України від 28 червня 1996 року. Переважно в ії приписах містяться загальні та непорушні права людини і громадянина та завдання держави, які формують іiі пріоритетну й основну політику забезпечення інформаційної безпеки та встановлення ії основоположною функцією держави (ч. 1 ст. 17), кожному гарантується право вільного доступу до інформації про стан довкілля, про якість харчових продуктів і предметів побуту, а також право на її поширення (ч. 2 ст. 50) тощо. Однак Конституція України не визначає основ інформаційного забезпечення адміністративного судочинства, таке явище більш поширене на рівні законів України [1]. Серед законодавства, яке створює базис для формування інформаційного забезпечення тих самих окружних адміністративних судів України, слід виокремити Кодекс адміністративного судочинства України, який поступово з перебігом часу та нововведень умістив у себе основу інформаційної політики судового апарату, а також Закон України «Про судоустрій і статус суддів», що визначив організацію судової влади на всіх рівнях та в різних правових сферах правосуддя України [6; 7]. Отже, як бачимо, розвиток автоматизованої системи документообігу суду було розпочато ще до прийняття у 2001 році Кримінального кодексу України. Це було спрямовано насамперед на захист документації, яка належить судовій системі, а також на спрощення самого процесу документообігу.

Закон України «Про внесення змін до деяких законодавчих актів України щодо запровадження автоматизованої системи документообігу в адміністративних судах» від 5 червня 2006 року започаткував та передбачив функціонування такої автоматичної системи, яка позитивно вплинула на діяльність судового апарату [7]. Додатком до цього Закону можна назвати Положення про автоматизовану систему документообігу суду, яке було затверджено Радою суддів України від 26 листопада 2010 року. Згідно з цим положенням автоматизована система документообігу суду становить сукупність комп'ютерних програм і відповідних програмно-апаратних комплексів судів та Державної судової адміністрації України, що забезпечує функціонування документообігу суду, обіг інформації між судами різних інстанцій та спеціалізацій, передачу інформації до центральних баз даних залежно від спеціалізації судів, захист від несанкціонованого доступу тощо [6]. Саме така система є основою для сучасної бази, яка постійно оновлюється відповідно до вимог захисту та інших необхідних для iii iснування характеристик. Пізніше саме Кодексом адміністративного судочинства було встановлено головну мету автоматизованої системи, іiі завдання та порядок функціонування в ст. 15-1, що прямо вказало на ії провідну роль у системі інформаційного забезпечення i окружних адміністративних судів. Ще одним складником системи є Єдиний реєстр судових рішень, ведення якого забезпечується Державною судовою адміністрацією України, а основні його положення та правові засади - Законом України «Про доступ до судових рішень» від 22 грудня 2005 року [7]. До речі, Єдиний реєстр судових рішень на сьогодні є достатньо популярним ресурсом, який надає доступ до найважливіших документів судів України, при цьому персональні дані, які відповідно до вимог нормативно-правових актів України не мають бути розповсюджені, надійно захищені. У реєстрі викладена виключно загальна інформація, яка не може жодним чином негативно вплинути на права та інтереси суб'єктів захисту. У цьому контексті можна стверджувати про диференційований та виважений підхід законодавця до безпеки інформації та захисту персональних даних.

Завдяки цьому адміністративне судочинство мало змогу швидко та ефективно розвивати внутрішню систему взаємозв'язків між судами, що впливало й на швидкість прийняття рішень у справах. Порядок формування та ведення реєстру було затверджено Кабінетом Міністрів України в постанові від 25 травня 2006 року [7]. У цьому документі також було визначено питання стосовно його фінансування, особливості програмного забезпечення, повноваження адміністраторів і держателів реєстру та інші умови функціонування, за яких його робота буде злагодженою та максимально ефективною в ході змін, доповнень або інших дій, які вплинуть на його існування [7]. На підставі зазначеного можна зробити висновок, що 
саме 32006 року розпочався активний розвиток автоматизованої системи документообігу суду, що зумовило необхідність кримінально-правової охорони.

Саме тому в ч. 1 Закону України від 5 червня 2009 року № 1475-VI «Про внесення змін до деяких законодавчих актів України щодо запровадження автоматизованої системи документообігу в адміністративних судах» було вказано на необхідність доповнити Кримінальний кодекс України статтею 376-1 такого змісту: «Стаття 376-1. Незаконне втручання в роботу автоматизованої системи документообігу суду. 1. Умисне внесення неправдивих відомостей чи несвоєчасне внесення відомостей до автоматизованої системи документообігу суду, несанкціоновані дії з інформацією, що міститься в автоматизованій системі документообігу суду, чи інше втручання в роботу автоматизованої системи документообігу суду, вчинене службовою особою, яка має право доступу до цієї системи, або іншою особою шляхом несанкціонованого доступу до автоматизованої системи документообігу суду, - караються штрафом від шестисот до тисячі неоподатковуваних мінімумів доходів громадян або обмеженням волі на строк від двох до п'яти років, або позбавленням волі на строк до трьох років, з позбавленням права обіймати певні посади або займатися певною діяльністю на строк від одного до трьох років. 2. Дії, передбачені частиною першою цієї статті, вчинені за попередньою змовою групою осіб, - караються обмеженням волі на строк від трьох до п'яти років або позбавленням волі на строк від трьох до шести років, 3 позбавленням права обіймати певні посади або займатися певною діяльністю на строк від двох до трьох років» [8]. Станом на 2021 рік ця редакція статті залишається актуальною та лише очікує зміни у зв'язку з прийняттям відповідних нормативно-правових актів.

Законом України «Про внесення змін до Господарського процесуального кодексу України, Цивільного процесуального кодексу України, Кодексу адміністративного судочинства України та інших законодавчих актів» від 3 жовтня 2017 року в роботу адміністративного судочинства було внесено низку позитивних змін, зокрема щодо інформаційного забезпечення. Так, у вказаному Законі було ухвалено пріоритетність інформаційного забезпечення в судах та створення Єдиної судової інформаційнотелекомунікаційної системи (далі - ССITC), яка фактично бере на себе головну роль у розпорядженні судовим процесом [7]. Статтею 18 Кодексу адміністративного судочинства України було визначено порядок та умови роботи системи, наголошуючи на тому, що законодавець має на меті повністю відцифрувати та перевести в електронний формат судовий процес [7].

Висновки. Отже, розвиток автоматизованої системи документообігу суду став одним iз напрямів удосконалення процесу інформатизації та комп'ютеризації діловодства в державі, підтвердженням стрімкої еволюції технічного прогресу. На сьогодні вказана система надає можливість не тільки прискорити процес роботи, а й дозволяє отримати швидкий доступ до необхідних документів, які знаходяться у вільному користуванні через інтернет-мережу (прикладом є Єдиний реєстр досудових рішень тощо). Однак саме спрощення інформаційної взаємодії призвело до виникнення низки ситуацій, які створюють загрозу кримінальноправовій та кримінологічній безпеці України, у зв'язку з чим у 2009 році було прийнято рішення про криміналізацію незаконного втручання в роботу автоматизованої системи документообігу суду.

Необхідно зазначити, що розвиток досліджуваного феномену пройшов достатньо короткий шлях, який можна умовно поділити на декілька етапів, які його зумовили: 1) етап становлення та розвитку технічного прогресу в українській державі (1996-2001рр.) визнання забезпечення інформаційної безпеки та безпеки інформації найважливішою функцією держави; 2) етап активного нормативно-правового розвитку (2001-2009 рр.) прийняття основних нормативно-правових актів України, запровадження автоматизованої системи документообігу в судах; 3) етап загальної діджиталізації суспільства (2009 р. сьогодення) - активне використання автоматизованої системи документообігу суду, встановлення кримінально-правового захисту. 


\section{Список використаних джерел}

1. Конституція України від 28.06.1996 № 254к/96-BP. URL: http://zakon.rada.gov.ua/laws/show/254\%D0\%BA/96-\%D0\%B2\%D1\%80 (дата звернення: 19.04.2021).

2. Про Концепцію Національної програми інформатизації : Закон України від 4 лютого 1998 року № 75/98-BP. URL: https://zakon.rada.gov.ua/laws/show/75/98-вр\#Техt (дата звернення: 19.04.2021).

3. Карчевський М. В. Кримінально-правова охорона інформаційної безпеки України : монографія. Луганськ : РВВ ЛДУВС ім. Е. О. Дідоренка, 2012. 528 с.

4. Братель О. Поняття та зміст доктрини інформаційної безпеки. Право України. 2006. № 5. C. 36-41.

5. Про схвалення Програми інтеграції України до Європейського Союзу : Указ Президента України від 14 вер. 2000 р. № 1072/2000. Офіиійний вісник Президента України. URL: https://zakon.rada.gov.ua/laws/show/1072/2000\#Text (дата звернення: 19.04.2021).

6. Щодо Положення про автоматизовану систему документообігу суду : рішення Ради суддів України від 26 лист. 2010 р. № 30. Вісник Верховного Суду Украӥни. 2010. № 51. URL: https://zakon.rada.gov.ua/rada/show/v0025414-15\#Text (дата звернення: 19.04.2021).

7. Кліщенко В. О. Історико-правовий генезис інформаційного забезпечення діяльності окружних адміністративних судів України. URL: http://lsej.org.ua/2_2020/61.pdf (дата звернення: 19.04.2021).

8. Про внесення змін до деяких законодавчих актів України щодо запровадження автоматизованої системи документообігу в адміністративних судах : Закон України від 5 червня 2009 року № 1475-VI. URL: https://zakon.rada.gov.ua/laws/show/1475-17\#Tехt (дата звернення: 19.04.2021).

\section{References}

1. Konstytutsiia Ukrainy vid 28.06.1996 № 254k/96-VR [Constitution of Ukraine]. URL: http://zakon.rada.gov.ua/laws/show/254\%D0\%BA/96-\%D0\%B2\%D1\%80 (data zvernennia: 19.04.2021) [in Ukrainian].

2. Pro Kontseptsiiu Natsionalnoi prohramy informatyzatsii : Zakon Ukrainy vid 4 liutoho 1998 roku № 75/98-VR [About the concept of the National Informatization Program]. URL: https://zakon.rada.gov.ua/laws/show/75/98-вp\#Text (data zvernennia: 19.04.2021) [in Ukrainian].

3. Karchevskyi, M. V. (2012). Kryminalno-pravova okhorona informatsiinoi bezpeky Ukrainy : monohrafiia [Criminal Protection of Information Security of Ukraine : monograph]. Luhansk : RVV LDUVS im. E. O. Didorenka. 528 s. [in Ukrainian].

4. Bratel, O. (2006). Poniattia ta zmist doktryny informatsiinoi bezpeky. [The concept and content of the doctrine of information security]. Pravo Ukrainy. № 5. S. 36-41 [in Ukrainian].

5. Pro skhvalennia Prohramy intehratsii Ukrainy do Yevropeiskoho Soiuzu : Ukaz Prezydenta Ukrainy vid 14 ver. 2000 r. № 1072/2000 [On the approval of the Integration Program of Ukraine to the European Union : Decree of the President of Ukraine]. Ofitsiinyi visnyk Prezydenta Ukrainy. URL: https://zakon.rada.gov.ua/laws/show/1072/2000\#Text (data zvernennia: 19.04.2021) [in Ukrainian].

6. Shchodo Polozhennia pro avtomatyzovanu systemu dokumentoobihu sudu : rishennia Rady suddiv Ukrainy vid 26 lyst. 2010 r. № 30 [Regarding the Regulation on the Automated System of Documentation of the Court : the decision of the Council of Judges of Ukraine]. Visnyk Verkhovnoho Sudu Ukrainy. 2010. № 51. URL: https://zakon.rada.gov.ua/rada/show/v002541415\#Text (data zvernennia: 19.04.2021) [in Ukrainian].

7. Klishchenko, V. O. Istoryko-pravovyi henezys informatsiinoho zabezpechennia diialnosti okruzhnykh administratyvnykh sudiv Ukrainy [Historical and legal genesis of information 
support of the district administrative courts of Ukraine]. URL: http://lsej.org.ua/2_2020/61.pdf (data zvernennia: 19.04.2021) [in Ukrainian].

8. Pro vnesennia zmin do deiakykh zakonodavchykh aktiv Ukrainy shchodo zaprovadzhennia avtomatyzovanoi systemy dokumentoobihu v administratyvnykh sudakh : Zakon Ukrainy vid 5 chervnia 2009 roku № 1475-VI [On amendments to some legislative acts of Ukraine regarding the introduction of an automated system of document circulation in administrative courts : Law of Ukraine]. URL: https://zakon.rada.gov.ua/laws/show/1475-17\#Text (data zvernennia: 19.04.2021) [in Ukrainian].

Shcherbina Artem,

Graduate Student

(Donetsk State University of Internal Affairs, Mariupol)

ORCID: https://orcid.org/0000-0001-8600-1829

\section{GENESIS AND PREREQUISITES OF THE DEVELOPMENT OF THE AUTOMATED COURT DOCUMENT SYSTEM IN UKRAINE}

The article considers the peculiarities of the development of the automated court document management system in Ukraine. The author points out that the development of the studied phenomenon has passed a rather short way, which can be divided into several stages that led to it: 1) the stage of formation and development of technical progress in the Ukrainian state (1996-2001) - recognition of information security and information security the most important function of the state; 2) stage of active normative-legal development (2001-2009)-adoption of the basic normativelegal acts of Ukraine, introduction of the automated system of document circulation in administrative courts; 3) the stage of general digitalization of society (2009 - present) - the active use of the automated document management system of the court, the establishment of criminal protection. Attention is drawn to the fact that the development of an automated court document management system has become one of the ways to improve the process of informatization and computerization of office work in the country, confirming the rapid evolution of technical progress. Today, this system provides an opportunity not only to speed up the process, but also allows quick access to the necessary documents that are freely available via the Internet (an example is the Unified Register of pre-trial decisions, etc.). However, the simplification of information interaction has led to a number of situations that threaten the criminal law and criminological security of Ukraine, in connection with which in 2009 a decision was made to criminalize illegal interference in the automated document management system of the court. It turns out that the main purpose of creating an information protection system is, first of all, the implementation of an action plan to ensure national security. The protection of information belonging to the judiciary is no less important and can be considered as one of the areas of protection of our state. The popularization of the term «information security" began with the development of the media, the transition to document automation in Ukraine and general digitalization.

Key words: information security; Internet; criminal legislation; criminal offense; automated court document management system; digitalization. 


\title{
РОЗДІЛ ІV \\ КРИМІНАЛЬНИЙ ПРОЦЕС ТА КРИМІНАЛІСТИКА. ОПЕРАТИВНО-РОЗШУКОВА ДІЯЛЬНІСТЬ
}

УДК: 343.1

DOI: https://doi.org/10.32366/2523-4269-2021-75-2-132-139

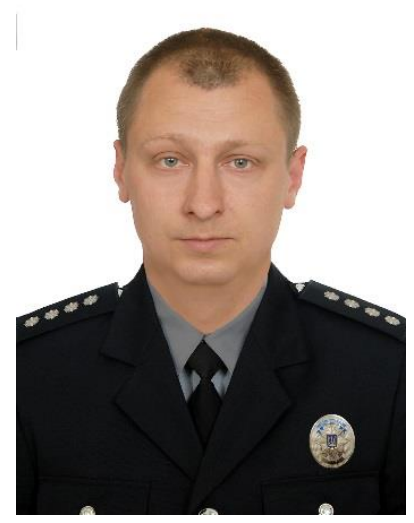

\author{
Воробей Андрій Олегович, \\ заступник начальника сектору дізнання \\ (Маріупольське районне управління полічії \\ ГУНП в Донеиькій області, м. Маріуполь) \\ ORCID: https://orcid.org/0000-0001-6629-9699
}

\section{ПРОБЛЕМНІ ПИТАННЯ ТА ПЕРСПЕКТИВИ ВДОСКОНАЛЕННЯ СПРОЩЕНОГО ДОСУДОВОГО РОЗСЛІДУВАННЯ}

\begin{abstract}
У статті розглянуто проблемні питання досудового розслідування кримінальних проступків підрозділами дізнання Національної полічії України. Вказано на проблеми процесуального статусу керівника органу дізнання та напрями його вдосконалення. Проаналізовано неузгодженості чинного кримінального процесуального законодавства в частині накладення арешту на майно та правової регламентації проведення обшуку під час здійснення дізнання. Звернуто увагу на недоліки регламентації строків досудового розслідування кримінальних проступків. Запропоновано впровадження скороченого порядку дізнання з метою реалізації принципу економії в кримінальному прочесі.
\end{abstract}

Ключові слова: інститут кримінальних проступків; дізнання; спрощене досудове розслідування; керівник органу дізнання; арешт майна.

Постановка проблеми. 01.07.2020 року набув чинності Закон України «Про внесення змін до деяких законодавчих актів України щодо спрощення досудового розслідування окремих категорій кримінальних правопорушень», яким уведено в дію інститут досудового розслідування кримінальних проступків. Незважаючи на очікувані зміни в кримінальному та кримінальному процесуальному законодавстві, науковцями і практичними працівниками було вказано на численні прогалини та неузгодженості цього закону [1]. Статистичні дані за 2020 рік свідчать, що підрозділами дізнання Національної поліції України розслідувалося близько половини всіх облікованих кримінальних правопорушень, середнє навантаження на одного штатного дізнавача Національної поліції України становило більше 100 кримінальних проваджень. Ефективність нововведення була досить низькою, оскільки за шість місяців 2020 року лише близько 7 відсотків від загальної кількості кримінальних проваджень, які знаходилися у провадженні органів дізнання Національної поліції України, спрямовувалися для розгляду до суду. Таким чином, практика застосування кримінального процесуального 
законодавства України показала суттєві недоліки вказаного закону, які виражені в неоднаковому застосуванні кримінальних процесуальних норм під час досудового розслідування у формі дізнання та неоднозначному тлумаченні цих норм суб'єктами кримінального провадження. Тому з'явилася необхідність дослідження проблемних питань, що виникають під час застосування правових норм, які регламентують досудове розслідування кримінальних проступків, та надання пропозицій щодо їх удосконалення.

Аналіз останніх досліджень та публікацій. Вивченню інституту спрощеного досудового розслідування присвячені роботи Ю. П. Аленіна, В. І. Божика, А. Ф. Волобуєва, I. В. Гловюка, Ю. М. Грошевого, К. П. Задоя, В. Т. Маляренка, В. О. Попелюшко, О. В. Сачко, О. Ю. Татарова, В. М. Трофименка, В. І. Фарінника, С. С. Чернявського та інших. Проте у працях указаних учених не досліджувалися питання правового статусу керівника органу дізнання 3 урахуванням змін до чинного законодавства, не аналізувалися процесуальні питання строків та порядку проведення окремих слідчих дій, не розглядалися питання тимчасово вилученого майна під час дізнання. На сьогодні в науці кримінального процесу немає пропозицій щодо можливості запровадження до чинного законодавства скороченої процедури проведення дізнання та взагалі можливості диференціації форм дізнання.

Метою статті $є$ виділення проблемних питань, які виникають під час досудового розслідування кримінальних проступків у діяльності підрозділів дізнання Національної поліції України, які до цього часу не були досліджені, та надання пропозицій щодо вдосконалення чинного кримінального процесуального законодавства в цій частині.

Виклад основного матеріалу. Ефективність виконання завдань кримінального судочинства перебуває у прямій залежності від належної правової регламентації діяльності суб'єктів кримінального провадження. Упровадження інституту досудового розслідування кримінальних проступків узгоджується 3 низкою концептуальних документів, зокрема Рекомендацією № 6 R (87) 18 Комітету міністрів Ради Свропи державам-членам щодо спрощення кримінального правосуддя та Концепцією реформування кримінальної юстиції в Україні, схваленої рішенням Ради національної безпеки і оборони України від 15.02.2008 і затвердженої Указом Президента України № 311/2008 від 08.04.2008 [2; 3]. Зміни до чинного законодавства в частині правового регулювання досудового розслідування кримінальних проступків повинні відбуватися з урахуванням не тільки вказаних документів, а й також напрацювань науки кримінального процесу та потреб практики. Законом України «Про внесення змін до деяких законодавчих актів України щодо спрощення досудового розслідування окремих категорій кримінальних правопорушень» Кримінальний процесуальний кодекс України (далі - КПК України) доповнено п. 7-1 ч. 1 ст. 3 КПК України, відповідно до якого керівником органу дізнання $є$ начальник підрозділу дізнання органу Національної поліції, органу безпеки, органу, що здійснює контроль за додержанням податкового законодавства, органу Державного бюро розслідувань, а в разі відсутності підрозділу дізнання - керівник органу досудового розслідування [4]. Порівнюючи зміст поняття «керівник органу досудового розслідування», яке встановлено п. 8 ч. 1 ст. 3 КПК України, 3 визначенням «керівник органу дізнання», можна зробити висновок, що законодавець не відносить осіб, які займають посади заступників керівників органів дізнання, до керівників у розумінні п. 7-1 ч. 1 ст. 3 КПК України, що є процесуальною проблемою, оскільки в більшості підрозділів дізнання Національної поліції України у штаті передбачено посади заступників. У зв'язку з цим виникає логічне запитання: чи є особи, які займають посади заступників начальників підрозділів дізнання, суб'єктами кримінального процесу? На практиці заступники начальників підрозділів дізнання користуються повноваженнями, затвердженими ст. $39^{1}$ КПК України, однак не виключено, що суди під час розгляду кримінальних проваджень, які розслідували дізнавачі на підставі доручень заступників начальника підрозділу дізнання, мають законні підстави визнати докази, отримані на підставі такого доручення, недопустимими, оскільки законодавцем не визначено повноваження вказаного суб'єкта кримінального процесу. Слід зазначити, що програмне забезпечення Єдиного реєстру досудових розслідувань (далі - СРДР) дає можливість посадовим особам, що 
займають посаду заступників начальника дізнання, призначати дізнавачів, які будуть здійснювати досудове розслідування кримінальних проступків, що, у свою чергу, не узгоджується 3 вимогами чинного кримінального процесуального законодавства. Беззаперечно, така прогалина повинна бути усунена законодавцем. Убачається доцільним п. 7-1 ч. 1 ст. 3 КПК України доповнити положенням, відповідно до якого під керівником органу дізнання потрібно розуміти не тільки начальника підрозділу, а i його заступника. Інше зауваження стосується змісту терміна «керівник органу дізнання», тому що до керівників дізнання законодавцем віднесено посадових осіб органів безпеки. Така позиція виглядає сумнівною, оскільки до підслідності Служби безпеки України взагалі не віднесено жодного складу кримінального проступку та, як наслідок, органи дізнання у вказаному правоохоронному органі взагалі не створювалися. Відповідно до ч. 3 ст. 38 КПК України дізнання здійснюють підрозділи дізнання або уповноважені особи інших підрозділів: органів Національної поліції; органів безпеки; органів, що здійснюють контроль за додержанням податкового законодавства; органів Державного бюро розслідувань; Національного антикорупційного бюро України (далі - НАБУ). Згідно з ч. 5 ст. 216 КПК України до підслідності НАБУ належать кримінальні проступки, передбачені ч. 1 ст. $366^{2}$ Кримінального кодексу України (далі - КК України) та ст. $366^{3}$ КК України, тому варто доповнити визначення «керівник органу дізнання» положенням про те, що до керівників органу дізнання відносяться начальник та заступник начальника підрозділів дізнання НАБУ. Зважаючи на викладене вище, пропонуємо таке тлумачення терміна «керівник органу дізнання»: начальник підрозділу дізнання органу Національної поліції, органу, що здійснює контроль за додержанням податкового законодавства, підрозділу Державного бюро розслідувань, підрозділу Національного антикорупційного бюро та його заступники, які діють у межах своїх повноважень, а в разі відсутності підрозділу дізнання - керівник органу досудового слідства.

Аналіз ст. $39^{1}$ КПК України, у якій визначено повноваження керівника органу дізнання, дає можливість виокремити певні проблемні питання. Так, необхідно звернути увагу на те, що законодавцем не надано повноважень керівнику дізнання визначати групу дізнавачів за кримінальним провадженням, на відміну від керівника органу досудового розслідування, який такими повноваженнями наділений. Зазначимо, що програмне забезпечення ЄРДР надає можливість керівникам підрозділів дізнання призначати за кримінальним провадженням групу дізнавачів, крім того, за певними категоріями кримінальних проступків, які мають певні складнощі в розслідуванні та вимагають проведення великого обсягу слідчих дій у короткі терміни, здійснення розслідування групою дізнавачів буде сприяти ефективному та швидкому розслідуванню. Без внесення відповідних змін до КПК України здійснення дізнання групою дізнавачів є незаконним, а суди мають усі підстави визнавати докази, отримані під час проведення слідчих дій групою дізнавачів, недопустимими, оскільки керівник підрозділу дізнання, призначаючи групу дізнавачів, виходить за межі наданих йому процесуальних повноважень. 3 огляду на зміст положень ч. 2 ст. $39^{1}$ КПК України керівник органу дізнання, на відміну від керівника органу досудового розслідування, не має повноважень здійснювати досудове розслідування, користуючись повноваженнями дізнавача. Така позиція законодавця $\epsilon$ суперечливою, тому що, по-перше, сам законодавець відносить керівника органу дізнання до сторони обвинувачення, не наділяючи при цьому правом проводити слідчі дії, по-друге, на посаду керівників дізнання, як правило, призначаються досвідчені працівники, які мають досвід слідчої роботи, а отже, на нашу думку, останні мають право та повинні здійснювати розслідування найбільш резонансних та складних кримінальних проваджень.

Аналіз судової практики щодо накладення арешту на майно, яке вилучене під час здійснення досудового розслідування у формі дізнання, вказує на неоднаковість застосування судами правової норми, передбаченої ст. $298^{3}$ КПК України. Наприклад, ухвалою слідчого судді Київського районного суду м. Одеси від 30.12 .2020 року заявнику відмовлено в клопотанні щодо повернення автомобіля, що був вилучений у межах кримінального провадження за ст. 290 КК України та визнаний речовим доказом, тому що, на думку слідчого судді, ч. 1 ст. $298^{3}$ КПК України не передбачено обов'язку сторони обвинувачення 
звертатися до слідчого судді з клопотанням про арешт стосовно майна, яке було тимчасово вилучене в результаті дізнання щодо кримінального проступку та якщо таке майно визнано речовим доказом [5]. Аналогічна точка зору висловлена в ухвалі слідчого судді Глобинського районного суду Полтавської області від 06.01.2021 року, відповідно до якої слідчий суддя дійшов висновку, що накладення арешту на майно, що визнане речовим доказом під час дізнання, нормами КПК не передбачено [6]. Протилежна позиція висловлена в ухвалі Богуславського районного суду Київської області від 06.11.2020 року, згідно з якою слідчим суддею накладено арешт на майно, що було предметом посягання за ч. 1 ст. 190 КК України на підставі вимог ст.ст. 170-173 КПК України [7]. Аналіз положень ст. $298{ }^{3}$ КПК України дає можливість стверджувати, що законодавець дійсно не вимагає від сторони обвинувачення звертатися до слідчого судді з клопотанням про арешт речових доказів у вигляді речей i документів, що $\epsilon$ знаряддям та/або засобом учинення кримінального проступку чи безпосереднім предметом посягання. Така позиція законодавця насамперед обумовлюється спрощеною формою досудового розслідування кримінальних проступків та принципом процесуальної економії. Однак, зважаючи на зміст ст. 98 КПК України, поняття речових доказів є ширшим та включає в себе не тільки речі та документи, передбачені ст. $298{ }^{3}$ КПК України, а й матеріальні об'єкти, які зберегли на собі його сліди або містять інші відомості, що можуть бути використані як доказ факту чи обставин, які встановлюються під час кримінального провадження, а також гроші, цінності та інші речі, набуті кримінально протиправним шляхом або отримані юридичною особою внаслідок учинення кримінального правопорушення. Відповідно до п. 5 ч. 1 ст. 169 КПК України тимчасово вилучене майно в кримінальному провадженні щодо кримінального проступку повертається особі, у якої було вилучене на підставі вироку суду. Вважаємо, що вказане положення закону не відповідає принципу недоторканності права власності, який закріплений ст. 16 КПК України та відповідно до якого позбавлення або обмеження права власності під час кримінального провадження здійснюється лише на підставі вмотивованого судового рішення, ухваленого в порядку, передбаченому КПК України. Отже, чинна редакція правових норм, передбачених ст.ст. 169, $298^{3}$ КПК України, надає право під час здійснення дізнання стороні обвинувачення тимчасово вилучати будь-які речі, які відповідають критеріям тимчасово вилученого майна, визначених ч. 2 ст. 167 КПК України, та утримувати таке майно до винесення вироку суду. На нашу думку, вказана позиція законодавця може та буде призводити до зловживань правоохоронних органів, оскільки надає можливість стороні обвинувачення утримувати вилучене майно необмежений проміжок часу. Слушно зазначити, що не всі кримінальні провадження щодо кримінальних проступків розслідуються в найкоротші терміни. Наприклад, кримінальні провадження щодо кримінальних проступків так званої економічної спрямованості можуть розслідуватися роками та лише деякі з них закінчуються судовим вироком. Оскільки розслідування кримінальних проступків у формі дізнання здійснюється у спрощеній формі, все ж правильним, уважаємо, є звільнення сторони обвинувачення від обов'язку звертатися до слідчого судді з клопотанням про накладення арешту на майно в судому порядку з метою збереження речових доказів. Проте з метою недопущення зловживань правоохоронних органів своїм правом, на нашу думку, у главі 25 КПК України необхідно передбачити право осіб, у яких таке майно вилучено чи яким таке майно належить, звертатися до суду з клопотанням про перевірку обгрунтованості вилучення та зберігання речових доказів стороною обвинувачення та вимагати передачі на зберігання їм таких речових доказів.

Науковцями неодноразово наголошувалося на проблемних питаннях регламентації строків досудового розслідування кримінальних проступків [1, с. 42-44; 8; 9]. На наше переконання, максимальний строк досудового розслідування у формі дізнання, передбачений ст. 219 КПК України та який становить один місяць з моменту повідомлення особі про підозру, хоч і відповідає принципу процесуальної економії, проте в кримінальних провадженнях, за якими необхідно призначити та виконати амбулаторну судово-психіатричну експертизу підозрюваного або стаціонарну судово-психіатричну експертизу, цього строку недостатньо через необхідність проведення підготовчих процесуальних дій, зокрема таких, як тимчасовий 
доступ до медичних документів підозрюваного. У разі відмови підозрюваного від участі у проведенні такої експертизи дізнавач буде змушений звертатися з клопотанням про примусове залучення такої особи до слідчого судді, що також вимагає затрати певного часу. Подібні судові експертизи проводяться у строки до 30 діб, у зв'язку з чим уважаємо правильною думку, що найбільш оптимальним законодавчо встановленим строком у цьому разі буде строк два місяці з моменту повідомлення особі про підозру в учиненні кримінального проступку, як і у випадку досудового розслідування злочинів.

У ході застосування правових норм, передбачених ст.ст. 234-236 КПК України, якими регулюється порядок отримання дозволу та порядок проведення обшуку під час дізнання, правозастосовна практика також є суперечливою. 3 одного боку, вказані норми надають дозвіл звертатися до суду з клопотанням на проведення обшуку тільки слідчому за погодженням 3 прокурором або прокурору, а також дають можливість реалізації ухвали суду щодо проведення обшуку тільки слідчому або прокурору. Проте відповідно до приписів ст. $40{ }^{1}$ КПК України дізнавач під час здійснення дізнання наділяється повноваженнями слідчого та має право звертатися за погодженням із прокурором до слідчого судді з клопотаннями проведення слідчих (розшукових) дій, негласних слідчих (розшукових) дій. Слідчі судді, розглядаючи клопотання дізнавачів щодо надання дозволу на проведення обшуку, в одних випадках відмовляють у їх задоволенні з тієї причини, що ст. 234 КПК України прямо не передбачено право дізнавача звертатися 3 таким клопотанням, в інших - задовольняють, зважаючи на приписи ст. $40{ }^{1}$ КПК України.

Автор як практичний працівник може зазначити, що досудове розслідування кримінальних проступків за своєю суттю $є$ не спрощеним, а прискореним досудовим розслідуванням. Така позиція пояснюється тим, що під час проведення дізнання дізнавачі Національної поліції України, керуючись принципом законності, повинні провести необхідні слідчі та процесуальні дії, щоб з'ясувати всі обставини кримінального правопорушення та ті, що становлять предмет доказування. Водночас строки 3 моменту повідомлення особі про підозру є скороченими та ставлять сторону обвинувачення у досить жорсткі межі для швидшого прийняття остаточного рішення. Варто погодитися 3 твердженням В. М. Трофименка, який вважає, що аналіз установленої чинним кримінальним процесуальним законодавством процесуальної форми провадження щодо кримінальних проступків є диференціацією за матеріальним (кримінально-правовим) критерієм і поєднує прискорену процедуру досудового розслідування (дізнання) та спрощену форму судового провадження в суді першої інстанції. На думку науковця, дізнання не може характеризуватися як спрощений порядок, оскільки, на відміну від сумарної процедури, що може бути під час судового провадження щодо кримінальних проступків, не передбачає істотних змін процесуальної форми та спрощення процесуального механізму гарантування прав і законних інтересів учасників кримінального провадження [10, с. 340]. Порядок спрощеного досудового розслідування кримінальних правопорушень затверджений кримінальними процесуальними законодавствами Латвії, Естонії, Республіки Казахстан, Російської Федерації, Киргизії, Швейцарії, Франції, Німеччини, США, Великобританії та інших держав [11, с. 30-36]. Законодавство деяких з цих країн передбачає кримінально-процесуальне заохочення для осіб, які визнають провину в учиненні кримінального правопорушення, відшкодували завдану шкоду, не оспорюють установлені фактичні обставини справи та заявили клопотання про спрощений розгляд, у вигляді призначення покарання значно меншого від верхньої межі покарання, що передбачено санкцією статті за вчинене кримінальне правопорушення. На наше переконання, дослідження можливості запровадження в українському кримінальному процесуальному законодавстві скороченої процедури проведення дізнання за очевидними кримінальними проступками (без проведення повного комплексу слідчих та процесуальних дій) щодо осіб, які беззаперечно визнають вину в учиненні кримінального проступку, поряд зі спрощеним судовим розглядом обвинувального акта з подальшим призначенням покарання, яке $\epsilon$ нижчим від верхньої межі покарання, встановленого санкцією відповідної статті КК України, є на сьогодні актуальним. Наявна в Україні процесуальна форма розслідування 
кримінальних проступків передбачає необхідність проведення всього комплексу слідчих та процесуальних дій у скорочені строки навіть за очевидними кримінальними правопорушеннями, коли підозрюваний беззаперечно визнає вину та відшкодував завдану шкоду, а це, враховуючи значну завантаженість підрозділів дізнання, має негативні наслідки. Упровадження скороченого порядку проведення дізнання можливе лише за чітко визначеним колом кримінальних проступків, законодавством мають бути затверджені гарантії забезпечення прав підозрюваних від зловживань правоохоронних органів та критерії, за яких скорочена форма дізнання $\epsilon$ неможливою. Вважаємо, що в українському кримінальному процесуальному законодавстві може бути встановлено принаймні два порядки розслідування кримінальних проступків: загальний та скорочений. Дослідження можливості впровадження скороченого порядку дізнання має практичне значення та $\epsilon$ актуальним напрямом для подальшого вивчення.

Висновки. На підставі проведеного дослідження було вказано на деякі проблемні питання, що виникають під час застосування правових норм, якими регулюється досудове розслідування у формі дізнання, та запропоновано шляхи їх вирішення. Зазначено, що чинне кримінальне процесуальне законодавство в частині регламентації досудового розслідування кримінальних проступків потребує вдосконалення. Автором запропоновано впровадження скороченого порядку дізнання з метою реалізації принципу економії в кримінальному процесі.

\section{Список використаних джерел}

1. Актуальні питання теорії та практики досудового розслідування кримінальних проступків : матеріали міжвідом. наук.-практ. круглого столу (Київ, 14 листоп. 2019 р.) / редкол.: В. В. Чернєй, С. Д. Гусарєв, С. С. Чернявський та ін. Київ : Нац. акад. внутр. справ, 2019. 197 c.

2. Стосовно спрощення кримінального правосуддя : рекомендації № $6 \mathrm{R}$ (87) 18 Комітету міністрів Ради Свропи державам-членам. URL: https://zakon.rada.gov.ua/laws/show/994_339 (дата звернення: 28.02.2021).

3. Концепції реформування кримінальної юстиції в Україні, схваленої рішенням Ради національної безпеки i оборони України від 15.02.2008 p. URL: https://zakon.rada.gov.ua/laws/show/311/2008 (дата звернення: 28.02.2021).

4. Кримінальний процесуальний кодекс України станом на 13.03 .2020 р. № 4651VI. URL: https://zakon.rada.gov.ua/laws/show/4651-17 (дата звернення: 28.02.2021).

5. Ухвала Київського районного суду м. Одеси від 30.12.2020 № 947/24345/20. URL: https://reyestr.court.gov.ua/Review/93958591 (дата звернення: 28.02.2021).

6. Ухвала Глобинського районного суду Полтавської області від 06.01.2021 № 527/1892/20. URL: https://reyestr.court.gov.ua/Review/94025530 (дата звернення: 28.02.2021).

7. Ухвала Богуславського районного суду Київської області від 06.11.2020 № 358/1321/20. URL: https://reyestr.court.gov.ua/Review/92686759 (дата звернення: 28.02.2021).

8. Кунтій А. I. Аспекти строку провадження дізнання в кримінальних провадженнях проти статевої свободи та статевої недоторканості дітей. Актуальні проблеми досудового розслідування та судового розгляду злочинів проти статевої свободи та статевої недоторканості дітей, шляхи їх вирішення : матеріали Міжнар. наук.-практ. конф. (Київ, 19 черв. 2020 р.) / редкол.: В. В. Чернєй, С. Д. Гусарєв, С. С. Чернявський, В. В. Корольчук. Київ: Нац. акад. внутр. справ, 2020. С. 136-138.

9. Кузубова Т. О. Законодавчі та прикладні проблемні питання строків проведення дізнання. Процесуальне та криміналістичне забезпечення досудового розслідування : тези доповідей учасників науково-практичного семінару (30 жовтня 2020 року) / упор. А. Я. Хитра. Львів : ЛьвДУВС, 2020. С. 60-63.

10. Трофименко В. М. Теоретичні та правові основи диференціації кримінального процесу України : дис. ... д-ра юрид. наук : 12.00.09. Харків, 2017. 437 с. 
11. Хавронюк М. І. Кримінальні проступки : науково-практичний коментар статей Кримінального кодексу України. Київ : ВД «Дакор», 2020. 266 с.

\section{References}

1. Aktualni pytannia teorii ta praktyky dosudovoho rozsliduvannia kryminalnykh prostupkiv [Pressing questions of theory and practice of pre-trial investigation of criminal misconducts] : materialy mizhvidom. nauk.-prakt. kruhloho stolu. Kyiv : Nats. akad. vnutr. sprav, 2019. 197 s. [in Ukrainian].

2. Stosovno sproshchennia kryminalnoho pravosuddia : rekomendatsii № 6 R (87) 18 Komitetu ministriv Rady Yevropy derzhavam-chlenam [In relation to simplification of criminal justice]. URL: https://zakon.rada.gov.ua/laws/show/994_339 (data zvernennia: 28.02.2021) [in Ukrainian].

3. Kontseptsii reformuvannia kryminalnoi yustytsii v Ukraini, skhvalenoi rishenniam Rady natsionalnoi bezpeky i oborony Ukrainy vid 15.02.2008 r. [Conceptions of reformation of criminal justice are in Ukraine]. URL: https://zakon.rada.gov.ua/laws/show/311/2008 (data zvernennia: 28.02.2021) [in Ukrainian].

4. Kryminalnyi protsesualnyi kodeks Ukrainy stanom na 13.03.2020 r. № 4651-6 [Criminal Procedure Code of Ukraine]. URL: https://zakon.rada.gov.ua/laws/show/4651-17 (data zvernennia: 28.02.2021) [in Ukrainian].

5. Ukhvala Kyivskoho raionnoho sudu m. Odesy vid 30.12.2020 № 947/24345/20 [Decision of the Kyiv District Court of Odessa of 30.12.2020 № 947/24345/20]. URL: https://reyestr.court.gov.ua/Review/93958591 (data zvernennia: 28.02.2021) [in Ukrainian].

6. Ukhvala Hlobynskoho raionnoho sudu Poltavskoi oblasti vid 06.01.2021 № 527/1892/20 [The decision of the Globinsky district court of the Poltava region from 06.01.2021 № 527/1892/20]. URL: https://reyestr.court.gov.ua/Review/94025530 (data zvernennia: 28.02.2021) [in Ukrainian].

7. Ukhvala Bohuslavskoho raionnoho sudu Kyivskoi oblasti vid 06.11.2020 № 358/1321/20 [The decision of the Boguslav district court of the Kyiv region from 06.11.2020 № 358/1321/20]. URL: https://reyestr.court.gov.ua/Review/92686759 (data zvernennia: 28.02.2021) [in Ukrainian].

8. Kuntii, A. I. (2020) Aspekty stroku provadzhennia diznannia v kryminalnykh provadzhenniakh proty statevoi svobody ta statevoi nedotorkanosti ditei [Aspects of term of realization of inquest are in criminal realizations against sexual freedom and sexual inviolability of children]. Kyiv: Nats. akad. vnutr. sprav. S. 136-138 [in Ukrainian].

9. Kuzubova, T. O. (2020) Zakonodavchi ta prykladni problemni pytannia strokiv provedennia diznannia [Legislative and applied problem questions of terms of realization of inquest]. Lviv: LvDUVS. S. 60-63 [in Ukrainian].

10. Trofymenko, V. M. (2017) Teoretychni ta pravovi osnovy dyferentsiatsii kryminalnoho protsesu Ukrainy [Theoretical and legal bases of differentiation of criminal process of Ukraine] : dys. ... d-ra yuryd. nauk : 12.00.09. Kharkiv. 437 s. [in Ukrainian].

11. Khavroniuk, M. I. (2020) Kryminalni prostupky : naukovo-praktychnyi komentar statei Kryminalnoho kodeksu Ukrainy [Criminal misconducts : research and practice comment of the articles of the Criminal code of Ukraine]. Kyiv: VD «Dakor». 266 s. [in Ukrainian]. 
Vorobey Andriy,

Deputy head of division of inquest

(Mariupol district police department Main Department

of the National Police in Donetsk region, Mariupol)

ORCID: https://orcid.org/0000-0001-6629-9699

\section{ISSUES AND PROSPECTS FOR IMPROVEMENT IN SIMPLIFYING THE PRE-TRIAL INVESTIGATION}

The article deals with the problematic issues of pre-trial investigation of criminal offenses, under investigation by the units of the National Police of Ukraine, have not been studied in the scientific literature. The author of the article points out the problems of the legal status of a head of an inquest body, the author's definition of this term is given and proposed changes to the current criminal procedural legislation, which should eliminate legal gaps. Considered the inconsistencies of the current criminal procedural legislation in terms of regulating the order of attachment for seizure of the property during the pre-trial investigation of criminal offenses. Analyzed judicial practice on this issue and proposed changes to legislation according to the needs of practice. The drawbacks are noted in establishing the terms of pre-trial investigation of criminal offenses, which are caused by the need to conduct psychiatric and other forensic examinations, it is proposed to provide in the Criminal Procedure Code of Ukraine for an inquiry period of 2 months from the moment a person is informed of suspicion. The author's specified legal inconsistencies in the issue of regulating the conduct of a search during an inquiry, it is indicated that there is a need to standardize Articles 234-236 of the Criminal Procedure Code. Due to fact that the activities of the inquest bodies of the National Police of Ukraine are noticeably inefficient, it is proposed to introduce a shortened inquiry procedure in order to implement the principle of economy in the criminal process and saving resources used during the pre-trial investigation.The current procedural form of criminal investigation in Ukraine provides for the need to conduct a full range of investigative and procedural actions in a short time, even for obvious criminal offenses, when the suspect unequivocally pleads guilty and compensates for the damage, which has negative consequences. The introduction of an abbreviated procedure for inquiry is possible only for a clearly defined range of criminal offenses, the legislation must approve guarantees to ensure the rights of suspects from law enforcement abuses and the criteria under which an abbreviated form of inquiry is impossible. The study of the possibility of implementing an abbreviated order of inquiry is of practical importance and is an important area for further study.

Key words: institute of criminal offenses; inquiries; simplified pre-trial investigation; a head of an inquest body; seizure of a property.

Надіслано до редколегії 05.03.2021

Рекомендовано до публікації 12.03.2021 


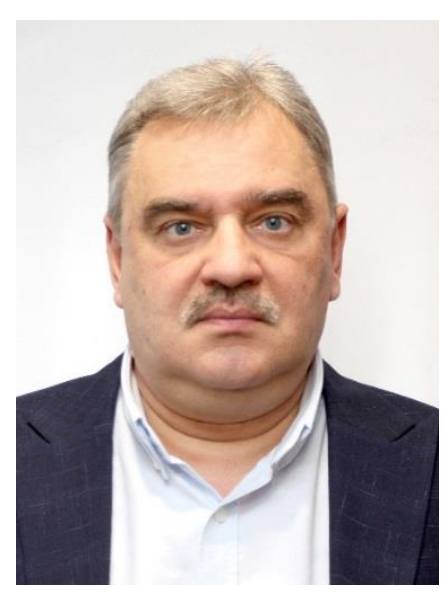

Ковальов Костянтин Миколайович, заступник директора

(Державний науково-дослідний експертнокриміналістичний иентр МВС України, м. Київ)

ORCID: https://orcid.org/0000-0003-1964-9283

\section{СПЕЦАЛЬНІ ЗНАННЯ В СУДОВІЙ ЕКСПЕРТИЗІ ВИЗНАЧЕННЯ ДАВНОСТІ ДОКУМЕНТА}

У статті сформовано кониептуальне бачення напрямів удосконалення науково-методичних засад застосування спеціальних знань у галузі криміналістичного документознавства через створення в межах судової технічної експертизи документів нової експертної спеціальності - визначення давності документа (індекс 2.4). Визначено коло спеціальних знань у галузі криміналістичного документознавства, якими має володіти експерт-документознавець. Проаналізовано погляди вчених щэодо змісту спеціальних знань у ретроспективі, узагальнено наукові підходи до виокремлення основних иілей використання спеціальних знань. На иій підставі констатовано, щуо дискусія з цуього приводу триває, зумовлюючи дочільність визначення спеціальних знань за галузями їх застосування. Сформульовано дефініцію «спеціальні знання в галузі криміналістичного документознавства».

Ключові слова:

судова експертиза; судова технічна експертиза документів; експертна спеціальність; визначення давності документа; криміналістичне документознавство; спеціальні знання; спеціальні знання в галузі криміналістичного документознавства; судовий експерт; експерт-документознавець.

Постановка проблеми. Судова експертиза визначення давності документів не втрачає свої актуальності навіть у період електронізації документообігу, що стрімко розвивається в Україні та світі. При цьому для підвищення рівня судово-експертного супроводження розслідування злочинів, пов'язаних із приховуванням і навмисною зміною часу виготовлення документа, особливої ваги набувають спеціальні знання, якими мають володіти судові експерти, виконуючи поставлені перед ними завдання.

Аналіз останніх досліджень і публікацій. Над питаннями визначення сутності спеціальних знань, їхніх характерних ознак, застосування в судочинстві працювало не одно покоління вчених-криміналістів, серед них: Л. Ю. Ароцкер, В. П. Бахін, Р. С. Бєлкін, А. І. Вінберг, В. Г. Гончаренко, О. О. Ейсман, А. В. Іщенко, Н. І. Клименко, В. К. Лисиченко, М. В. Салтевський, М. Я. Сегай. У цьому напрямі здійснюють дослідження В. В. Коваленко, Б. Є. Лук'янчиков, Є. Д. Лук'янчиков, І. В. Пиріг, К. О. Чаплинський, Ю. В. Шепітько, М. Г. Щербаковський та інші практики й теоретики.

Наразі висвітлюються різні аспекти порушеної проблематики: роль спеціальних знань у кримінальному судочинстві України [1]; особливості використання спеціальних знань у 
кримінальних провадженнях [2]; сутність, структура та цілі використання спеціальних знань у судочинстві [3]; поняття і правове регулювання використання спеціальних знань, умінь i навичок у кримінальному провадженні [4]; форми використання спеціальних знань [5]; використання спеціальних знань у кримінальних провадженнях [6; 7]; види спеціальних знань, що використовуються під час розслідування злочинів [8]; принципи застосування спеціальних знань у кримінальному провадженні [9]; поняття, сутність і форми спеціальних знань, що застосовуються під час розслідування злочинів [10]; проблемні питання призначення та проведення судової експертизи в господарському судочинстві [11]; використання спеціальних знань у судово-експертній діяльності (теоретико-правові аспекти) [12] та ін.

Зарубіжні колеги опрацьовують, зокрема, такі питання: феномен розвитку експертизи, реляційні аспекти експертизи, ефективність застосування спеціальних знань під час розслідування злочинів, спеціалізація фахівця як результат наполегливої праці і тривалого навчання тощо $[13 ; 14 ; 15 ; 16 ; 17 ; 18]$.

Але проблеми, пов'язані з використанням спеціальних знань у судовій експертизі давності документа, науково-методичні підходи до підготовки фахівців 3 такого виду дослідження, методичне забезпечення дослідження таких документів науковцями грунтовно не розглядалися, що й зумовлює актуальність обраної тематики, визначаючи напрями подальших розвідок.

Мета статті - сформувати концептуальне бачення напрямів удосконалення науковометодичних засад застосування спеціальних знань у галузі криміналістичного документознавства через створення в межах судової технічної експертизи документів нової експертної спеціальності - визначення давності документа (індекс 2.4).

Для досягнення цієї мети потрібно виконати такі завдання: надати ретроспективний аналіз наукової думки щодо змісту спеціальних знань; сформулювати дефініцію спеціальних знань у галузі криміналістичного документознавства; визначити обсяг спеціальних знань у галузі криміналістичного документознавства, яким мають володіти експерти-документознавці як окрема категорія обізнаних осіб; окреслити перспективні напрями розширення можливостей судової технічної експертизи документів із метою використання спеціальних знань під час визначення давності виготовлення документів.

Виклад основного матеріалу. Експерт, визначаючи давність документа, має послуговуватися практичними та науковими знаннями з різних галузей науки і техніки, вміло ïx застосовувати на практиці. Так, В.В. Коваленко під практичними розуміє знання, накопичені людьми в побуті та виробничій діяльності, виражені в так званих рецептурних правилах. Наукові знання, утворюючи розгалужену систему, зумовлені пізнавальною діяльністю людини на рівні теоретичного осмислення, заснованою на відповідній (спеціальній) освітній підготовці. Наукове знання спрямоване на вивчення суті явища, щоб досягти об'єктивної істини на підставі осмислення і пояснення установлених фактів [19, с. 73].

Практичні й наукові знання, що взаємозалежні і взаємозумовлені, постають базисом для спеціальних знань. Доцільно розкрити суть цього поняття.

Слово «знання» належить до загальновживаної лексики і тлумачиться як обізнаність у чому-небудь, наявність відомостей про кого-, що-небудь, володіння практичними навичками, уміння користуватися чим-небудь; сукупність відомостей з якої-небудь галузі, набутих у процесі навчання, дослідження і т. ін.; пізнання дійсності в окремих іiі виявах і в цілому, система відомостей про закономірності розвитку природи, суспільства, мислення; наука [20, c. $469 ; 21$, c. 1169$]$.

Лексема «спеціальний» має таке значення: призначений винятково для кого-, чогонебудь; який має особливе призначення; який стосується окремої галузі науки, техніки, мистецтва й т. ін.; призначений для спеціалістів (осіб, які досконало володіють певною спеціальністю, мають глибокі знання в якій-небудь галузі науки, техніки, мистецтва тощо; фахівців) цієї галузі [20, с. 1364]. У поєднанні зі словом «знання» становить термінологічне словосполучення «спеціальні знання» i, набуваючи понятійного змісту і процесуальноправового та криміналістичного значення, потребує визначення. 
Тобто спеціальними є знання (сукупність знань, певний обсяг інформації, потрібний для детального вивчення процесів і явищ, їх наслідків, умов виникнення та видозміна певних ознак, їх характеристик тощо), якими володіє конкретна особа (спеціаліст, фахівець) і які можуть використовуватися в різних сферах процесуально-правового врегулювання суспільних відносин.

О. О. Ейсман одним із перших розтлумачив поняття «спеціальні знання» як такі, що не $\epsilon$ загальнодоступними та загальновідомими, не мають масового поширення, і якими володіє обмежене коло фахівців [22, с. 90-91].

Водночас 3. М. Соколовський запропонував спеціальними знаннями вважати сукупність відомостей, отриманих у результаті професійної спеціальної підготовки, що створюють для їх власника можливість вирішувати питання у певній галузі [23, с. 202].

На думку М. В. Салтевського, «спеціальні знання - це сукупність професійних наукових, технічних чи практичних знань і навичок, якими володіє суб'єкт, що називається і використовується в кримінальному процесі як фахівець» [24, с. 78].

В. В. Коваленко визначає спеціальні знання як «наукові й практичні знання та навички, які відповідають сучасному рівню розвитку відповідних галузей людської діяльності (за винятком знань у галузі процесуального та матеріального права), використовуються (застосовуються) під час розслідування злочинів і судового розгляду кримінальних справ 3 метою сприяння слідству чи суду в збиранні та дослідженні доказів» [19, с. 45].

В. С. Кузьмічов та І. В. Пиріг спеціальні знання розглядають як «сукупність теоретичних знань і практичних умінь та навичок у галузі науки, техніки, мистецтва чи ремесла, набутих у результаті спеціальної теоретичної підготовки або професійного досвіду роботи, що використовуються з метою розкриття, розслідування та попередження злочинів» [25, с. 16].

О. А. Логвинець спеціальними вважає професійні знання в різних галузях діяльності, здобуті теоретичним навчанням та (або) практичним досвідом, використовувані під час розслідування злочинів або розгляду справ у суді [26, с. 98].

Д. А. Свірідов спеціальні знання розглядає як сукупність знань у різних галузях діяльності (теоретичній і практичній), здобутих, як правило, у межах вищої професійної освіти, що не є правовими, які використовують сторони кримінального судочинства і суд 3 метою виявлення і розслідування злочинів та запобігання їм відповідно до кримінального процесуального законодавства [27, с. 336-337].

Під спеціальними знаннями В. Ю. Шепітько розуміє «систему наукових даних (відомостей) або навичок об'єктивного характеру, отриманих у результаті вищої професійної підготовки, наукової діяльності, досвіду практичної роботи, що відповідають сучасному рівню» [28, с. 33].

На думку авторського колективу у складі О. О. Алєксєєва, В. В. Арешонкова, В. М. Атаманчука та ін., «спеціальні знання - це не пов'язані з веденням кримінального судочинства знання, які за змістом виходять за рамки загальноосвітніх та спеціальних освітніх програм, які використовуються для досягнення юридичних цілей в ході кримінального процесу» [29].

О. М. Шрамко визначає спеціальні знання як «сукупність наукових і практичних знань та навичок, якими володіють обізнані особи (спеціалісти, експерти), які відповідають сучасному рівню розвитку відповідних галузей людської діяльності (за винятком знань у галузі процесуального і матеріального права)» [8, с. 179].

I. М. Попович спеціальні знання характеризує як певну сукупність відомостей із будьякої галузі, набутих у процесі навчання та 3 досвіду практичної роботи, що ними володіє обмежене коло спеціалістів, яких використовують для отримання доказової інформації, необхідної для встановлення істини у справах, що перебувають у провадженні суду. Таким чином, судові експертизи призначаються у разі, коли для вирішення питань у справі необхідні спеціальні знання [11, с. 194-195].

А. Г. Вуйма під спеціальним знаннями розуміє знання в галузі конкретної науки i техніки, засвоєні внаслідок отримання відповідної освіти, та набуті на цій основі під час 
професійної діяльності навички, що є підставою для надання суб'єктами застосування цих знань (експертами та спеціалістами) консультацій або висновків, що стосуються обставин вчинення кримінального правопорушення [10, с. 57].

Окремий інтерес у контексті судово-експертної діяльності становить позиція, яку висловили М. Г. Щербаковський, А. В. Шмонін, О. В. Бишевець.

М. Г. Щербаковський, уважаючи спеціальними «професійні знання, навички, здобуті обізнаною особою у процесі практичної діяльності в різних галузях науки і техніки, що використовуються разом з науково-технічними засобами під час проведення експертизи [30, c. 49-50], запропонував поняття «спеціальні знання» розглядати в широкому сенсі (як знання в будь-якій сфері людської діяльності) та у вузькому (щодо галузі судочинства, коли спеціальні знання протиставляються правовим знанням осіб, які здійснюють професійні функції у кримінальному провадженні) [31, с. 42]. Згодом учений уточнив дефініцію, зазначивши, що «спеціальні знання - це систематизована інформація з різних галузей теоретичної та практичної діяльності, крім права, котру набувають в результаті професійного або самостійного навчання і досвіду з певної спеціальності, застосовують на основі умінь i навичок у процесуальній або непроцесуальній формах із метою збирання (формування), дослідження, перевірки доказів, установлення підстав для прийняття уповноваженими особами процесуальних, організаційних і тактичних рішень у судочинстві. Точний зміст, форма та ціль реалізації спеціальних знань залежать від функцій конкретного учасника судочинства, який їх використовує» [3, с. 192].

А. В. Шмонін наголошує, що спеціальні знання належать до різних галузей науки, техніки, мистецтва і ремесла, а їх застосування пов'язано з певним рівнем професійної освіти та (або) підготовки і професійним досвідом. При цьому такі знання, що не є загальновідомими, пов'язані з умінням користуватися спеціальними методами чи методиками [32, с. 3-8].

О. В. Бишевець під спеціальними знаннями розуміє «сукупність науково обгрунтованих відомостей окремого (спеціального) виду, якими володіють обізнані особи (експерти і спеціалісти) в різних галузях науки, техніки, мистецтва та ремесла і відповідно до норм законодавства використовують їх для успішного вирішення завдань кримінального провадження» [33, с. 190-191].

Проте, убачається, найбільш обгрунтовану й узагальнену дефініцію спеціальних знань, насамперед у контексті судово-експертної діяльності, сформулювали В. К. Лисиченко та В. В. Ціркаль, наголошуючи на тому, що це не загальновідомі в судочинстві наукові, технічні та практичні знання, яких набула в результаті професійного навчання чи роботи за окремою спеціальністю особа, залучувана як спеціаліст чи експерт з метою сприяння слідству або суду в 3'ясуванні обставин справи чи давання висновку з питань, вирішення яких потрібує ї застосування [34, с. 22].

3 огляду на те, що спеціальні знання застосовуються за певних обставин, В. К. Лисиченко на основі практичного досвіду й результатів наукових досліджень окреслив такі головні цілі використання наукових, практичних і спеціальних знань у досудовому розслідуванні й судовому розгляді незалежно від виду судочинства: отримання необхідних відомостей, що слугують підставою для прийняття обгрунтованих рішень у справі; використання знань спеціалістів для виявлення, закріплення, вилучення доказів і з'ясування спеціальних питань, що постають під час слідчих дій; дослідження певних об'єктів і явищ для встановлення обставин, що мають значення для вирішення справи [35, с. 50-51].

Цей перелік, поділяючи позицію, яку висловив В. М. Ковбаса [36, с. 228], можна розширити, додавши до головних цілей використання наукових, практичних і спеціальних знань ще й розроблення тактичних і технічних засобів та методів збирання доказів.

С. А. Коцюба і К. О. Чаплинський, узагальнюючи наукові думки 3 цього приводу, виокремили такі цілі використання спеціальних знань: сприяння повному і швидкому розкриттю та розслідуванню злочинів; установлення істини у кримінальній справі; дослідження певних об'єктів та явищ; отримання необхідних відомостей для встановлення обставин, що мають значення для правильних обгрунтованих рішень у справі; сприяння 
виявленню, фіксації та вилученню доказів і з'ясуванню спеціальних питань, що виникають під час слідчих дій; розроблення тактичних і технічних засобів та методів збирання доказів [2, c. 60].

Проте ця позиція, на нашу думку, потребує уточнення, оскільки варто говорити не про встановлення істини у кримінальній справі, а про встановлення істини у справі (кримінальному провадженні). Адже йдеться про кримінальне й інші види судочинства.

Тому пропонуємо таку класифікацію цілей використання спеціальних знань:

- сприяння швидкому й повному встановленню об’єктивної істини у справі (кримінальному провадженні);

- $\quad$ виявлення, фіксація, вилучення доказів і з'ясування спеціальних питань, що виникають під час слідчих дій або судового розгляду справи;

- $\quad$ розроблення тактичних і технічних засобів та методів збирання доказів;

- дослідження певних об'єктів, явищ і процесів для отримання необхідних відомостей, що мають значення для прийняття обгрунтованих рішень у справі;

- $\quad$ формування процесуальних документів, які закріплюють належне використання спеціальних знань у справі.

Зважаючи на те, що спеціальні знання не можуть існувати в абстрактній, нематеріальній формі, тобто без самої людини - суб'єкта процесуально-правових відносин, О. А. Кравченко започаткував таку класифікацію суб'єктів використання спеціальних знань: «а) державні органи й посадові особи, які ведуть процес: суд, суддя, прокурор, слідчий, начальник слідчого відділу, орган дізнання, особи, які провадять дізнання; б) фахівці, які мають процесуальні права та обов'язки, зумовлені наявністю в них спеціальних знань (спеціаліст, експерт, керівник експертної установи); в) фахівці, які не мають процесуальних прав та обов'язків (ревізор, технічний інспектор та ін.), у справі вони виступають у ролі свідків; г) інші учасники процесу (захисник, обвинувачений, потерпілий та його представник)» [37, с. 7].

Відповідно до законодавства України про судову експертизу, під судовою експертизою розуміють дослідження на основі спеціальних знань у галузі науки, техніки, мистецтва, ремесла тощо об'єктів, явищ і процесів з метою надання висновку з питань, що є або будуть предметом судового розгляду [38].

Головним суб’єктом застосування спеціальних знань у формі судової експертизи А. М. Таранова називає експерта [5, с. 201]. На наш погляд, ця позиція потребує уточнення, оскільки головним суб'єктом є судовий експерт, який має необхідні наукові, технічні або інші спеціальні знання для з'ясування обставин справи та (або) надання висновку з досліджуваних питань, а також застосовує їх повним обсягом відповідно до процесуальних повноважень та обмежень.

Поняття спеціальних знань судового експерта як суб'єкта використання спеціальних знань сформулював М. Г. Щербаковський, наголошуючи на тому, що «це систематизована інформація з різних галузей теоретичної і практичної діяльності, крім права, котру набувають експерти в результаті навчання у вищому навчальному закладі та досвіду 3 певної спеціальності, застосовують на основі умінь і навичок для проведення експертних досліджень представлених об'єктів та надання письмового висновку з питань, поставлених сторонами й судом [31, с. 65].

Судово-експертна діяльність охоплює десятки напрямів і понад 70 видів судових експертиз. Серед них і криміналістичне документознавство.

Як система знань криміналістичне документознавство складається із тісно пов'язаних між собою розділів (загальні положення криміналістичного документознавства; криміналістичне дослідження рукописів (письмового мовлення); криміналістичне дослідження рукописних текстів (почерку); техніко-криміналістичне дослідження документів), що грунтуються на досягненнях природничих і технічних наук, законодавстві та спеціальних знаннях у галузі загального документознавства, інформатики, поліграфії, історії, хімії, фізики, анатомії, медицини, психології [39, с. 13]. Тобто слід говорити про формування 
окремої категорії обізнаних осіб із професійними (спеціальними) знаннями - експертівдокументознавців у такій галузі знань, як криміналістичне документознавство [40, с. 60].

При цьому експерт-документознавець має опанувати спеціальні знання:

- $\quad$ із загальних положень криміналістичного документознавства: 3 історії писемності, передумов виникнення криміналістичного документознавства, про поняття та класифікацію документів, порядок поводження з документами та ін.;

криміналістичного дослідження рукописних текстів (почерку): стосовно дослідження змісту рукописних текстів, формування письмово-рухової навички, поняття почерку, ознак почерку, залежність почерку від віку, статі, стану виконавця, умов виконання рукописних записів та ідентифікації виконавця рукопису (підпису);

техніко-криміналістичного дослідження документів: пов'язані з технологією виготовлення документів, їхніх захисних елементів, способами поліграфічного друку, виготовлення печаток і штампів, видами підробок, способами підроблення та виявлення їх ознак, особливостями дослідження підписів щодо їх технічного підроблення, використанням матеріалів, які застосовуються для виготовлення бланків документів, оформлення реквізитів документів тощо [39, с. 13].

Отже, на часі створення принципово нового поняття спеціальних знань у галузі криміналістичного документознавства. При цьому, убачається, варто мати за основу критерії, сформовані науковцями [2, с. 59] для визначення поняття спеціальних знань (загальна мета використання спеціальних знань - сприяння вирішенню завдань кримінального судочинства, зокрема повному та швидкому розкриттю і розслідуванню злочинів; спеціальні знання грунтуються на сучасних досягненнях науки і техніки; спеціальні знання становлять сукупність теоретичних знань і практичних умінь та навичок).

3 огляду на зазначене вище пропонуємо під спеціальними знаннями в галузі криміналістичного документознавства розуміти систематизовані спеціальні професійні знання з різних галузей науки й техніки, а також практичні уміння і навички комплексного дослідження документів, яких набуває експерт чи спеціаліст під час навчання за відповідною програмою підготовки, проведення наукових досліджень і практичної роботи 3 дослідження документів, що використовуються для встановлення обставин справи та надання обгрунтованого висновку експерта на поставлені йому судом чи учасниками (сторонами) справи запитання.

Крім того, зважаючи на те, що визначення давності виготовлення документа є одним із завдань, які вирішуються криміналістичним документознавством, експерт-документознавець також повинен мати навички застосування аналітичних $\mathrm{i}$ спеціальних методів криміналістичного дослідження документів та специфічного обладнання.

Для опанування та систематизації таких знань, практичних умінь і навичок, а також навичок застосування аналітичних і спеціальних методів, визначення їх обсягу необхідно, запровадивши в межах судової технічної експертизи документів окрему експертну спеціальність - визначення давності документа (індекс 2.4), створити науковий базис і започаткувати нові підходи до підготовки судового експерта, розробивши відповідну спеціалізовану програму.

Висновки. Отже, з огляду на викладене вище можемо зробити низку висновків.

1. У результаті ретроспективного аналізу наукових позицій і поглядів учених щодо змісту спеціальних знань констатовано, що дискусія 3 цього приводу триває, зумовлюючи доцільність визначення спеціальних знань за галузями їх застосування.

2. Сформульовано дефініцію спеціальних знань у галузі криміналістичного документознавства, під якими слід розуміти систематизовані спеціальні професійні знання 3 різних галузей науки і техніки, а також практичні уміння і навички комплексного дослідження документів, яких набуває експерт чи спеціаліст під час навчання за відповідною програмою підготовки, проведення наукових досліджень і практичної роботи з дослідження документів, що використовуються для встановлення обставин справи та надання обгрунтованого висновку експерта на поставлені йому судом чи учасниками (сторонами) справи запитання. 
3. Наголошено, що колом спеціальних знань у галузі криміналістичного документознавства, якими мають володіти експерти-документознавці, становлячи окрему категорію обізнаних осіб, також мають охоплюватися навички застосування аналітичних $\mathrm{i}$ спеціальних методів криміналістичного дослідження документів та специфічного обладнання.

4. Зважаючи на обсяг спеціальних знань, якими мають володіти експертидокументознавці, науково обгрунтовано перспективні напрями розширення можливостей судової технічної експертизи документів, що передбачають створення нової експертної спеціальності - визначення давності документа (індекс 2.4) і започаткування нових підходів до підготовки судового експерта.

\section{Список використаних джерел}

1. Лазебний А. М. Роль спеціальних знань у кримінальному судочинстві України. Міжнародний юридичний вісник: збірник наукових праџь Національного університету державної податкової служби Украӥни. 2016. № 2 (4). С. 23-29.

2. Коцюба С. А., Чаплинський К. О. Особливості використання спеціальних знань у кримінальних провадженнях. Науковий вісник Дніпропетровського державного університету внутрішніх справ. Спецвип. № 1 (91) «Протидія наркозлочинності в Україні та у світі: проблеми та шляхи їх вирішення». 2018. C. 57-61. URL: http://er.dduvs.in.ua/bitstream/123456789/1863/1/3.pdf (дата звернення: 24.03.2021).

3. Щербаковський М. Г. Сутність, структура та цілі використання спеціальних знань у судочинстві. Теорія та практика судової експертизи і криміналістики. 2018. № 18. C. 184-193. DOI: https://doi.org/10.32353/khrife.2018.20.

4. Грібов М. Поняття та правове регулювання використання спеціальних знань, умінь і навичок у кримінальному провадженні. Науковий вісник Національної академії внутрішніх справ. 2019. № 1 (110). С. 13-21. DOI: https://doi.org/10.33270/01191101.13.

5. Таранова А. Форми використання спеціальних знань у розслідуванні неналежного виконання професійних обов'язків медичним або фармацевтичним працівником. Підприємництво, господарство $i$ право. 2019. № 10. C. 198-203. https://doi.org/10.32849/2663-5313/2019.10.34.

6. Лук'янчиков С. Д., Лук'янчиков Б. С., Петряєв С. Ю. Використання спеціальних знань у кримінальному провадженні. Вісник НТУУ «КПІ». Політологія. Соиіологія. Право. 2019. № 4 (44). C. 125-130. DOI: https://doi.org/10.20535/23085053.2019.4(44).199742.

7. Пілюков Ю. Використання спеціальних знань у кримінальних провадженнях. Актуальні проблеми правознавства. 2019. № 4(20). С. 240-245. DOI: https://doi.org/10.35774/app2019.04.240.

8. Шрамко О. Види спеціальних знань, що використовуються під час розслідування корупційних злочинів. Актуальні проблеми правознавства. 2019. № 2. С. 175180. URL: http://appj.wunu.edu.ua/index.php/appj/article/view/693. (дата звернення: 24.03.2021).

9. Марушев А. Д. Принципи застосування спеціальних знань у кримінальному провадженні. Актуальні проблеми держави $і$ права. 2020. № 86. C. 139-144. DOI: https://doi.org/10.32837/apdp.v0i86.2424.

10. Вуйма А. Г. Поняття, сутність та форми спеціальних знань, що використовуються під час розслідування вбивств. Вісник Луганського державного університету внутрішніх справ імені Е. О. Дідоренка. 2020. № 1 (89). С. 54-62.

11. Попович I. М. Проблемні питання призначення та проведення судової експертизи в господарському судочинстві. Теорія та практика судової експертизи $i$ криміналістики. 2019. № 20. С. 190-206. DOI: https://doi.org/10.32353/khrife.2.2019.14.

12. Надіжко М. М. Використання спеціальних знань у судово-експертній діяльності: теоретико-правові аспекти. Криміналістичний вісник. 2020. № 33 (1). C. 25-36. DOI: https://doi.org/10.37025/1992-4437/2020-33-1-25. 
13. Bourne L. E. Jr., Kole J. A., Healy A. F. Expertise: defined, described, explained. Front. Psychol. 2014. № 5. 186 p. DOI: https://doi.org/10.3389/fpsyg.2014.00186.

14. Grundmann R. The Problem of Expertise in Knowledge Societies. Minerva. 2017. № 55. P. 25-48. DOI: https://doi.org/10.1007/s11024-016-9308-7.

15. Пашутина О. С., Чеботарева И. Н. Использование знаний сведущих лиц при осуществлении защиты по уголовным делам: законодательный, доктринальный и правоприменительный аспекты. Известия Юго-Западного государственного университета. 2017. № 21 (3). C. 155-166. DOI: https://doi.org/10.21869/2223-1560-2017-21-3-155-166.

16. Koval I., Koval M., Frantsuz A., Koucherets D., Shpiliarevych V. Tactical Features of Use of Special Knowledge in the Investigation of Torture Committed by Members of the National Police of Ukraine. Journal Of Advanced Research In Law And Economics. 2019. № 10 (1). P. 263273. DOI: https://doi.org/10.14505//jarle.v10.1(39).27.

17. Littlejohn C. Truth, knowledge, and the standard of proof in criminal law. Synthese. 2020. № 197. P. 5253-5286. DOI: https://doi.org/10.1007/s11229-017-1608-4.

18. Swan R. H., Plummer K. J., West R. E. Toward functional expertise through formal education: identifying an opportunity for higher education. Education Tech Research Dev. 2020. № 68 (5). P. 2551-2568. DOI: https://doi.org/10.1007/s11423-020-09778-1.

19. Коваленко В. В. Застосування науково-технічних засобів спеціалістами при проведенні слідчих дій : монографія. Луганськ : РВВ ЛДУВС, 2007. 208 с.

20. Великий тлумачний словник сучасної української мови / за заг. ред. В. Т. Бусел. Київ, Ірпінь : Перун, 2005. 1728 с.

21. Словник української мови online. Томи 1-11. URL: https://services.ulif.org.ua/expl/Entry/index?wordid=37249\&page=1168 (дата звернення: 24.03.2021).

22. Эйсман А. А. Заключение эксперта. Структура и научное обоснование. М. : Юрид. лит., 1967. 152 с.

23. Соколовский 3. М. Понятие специальных знаний. Криминалистика и судебная експертиза. 1969. № 6. С. 199-205.

24. Салтевський М. В. Криміналістика (у сучасному викладі) : підручник. Київ : Кондор, 2005. 588 с.

25. Кузьмічов В. С., Пиріг I. В. Використання спеціальних знань при розслідуванні розкрадань вантажів на залізничному транспорті : монографія. Дніпропетровськ : Ліра ЛТД, 2008. $168 \mathrm{c}$.

26. Логвинец Е. А. О сущности специальных знаний. Научные ведомости БелГУ. Серия: Философия. Социология. Право. 2010. Вып. 12 № 8 (79). С. 98-102. URL: http://dspace.bsu.edu.ru/bitstream/123456789/3627/1/Logvinets\%20E_A_To\%20the\%20essence.pd f. (дата звернення: 24.03.2021).

27. Свиридов Д. А. К вопросу о сущности специальных знаний при расследовании преступлений. Ученье записки Таврического начионального университета им. В. И. Вернадского. Серия: Юридические науки. 2013. Т. 26 (65). № 1. С. 332-337. URL: http://www.juris.vernadskyjournals.in.ua/journals/2013/1_2013/54.pdf (дата звернення: 24.03.2021).

28. Шепітько В. Ю. Проблеми використання спеціальних знань крізь призму сучасного кримінального судочинства в Україні. Судова експертиза. 2014. № 1. С. 11-18.

29. Алєксєєв О. О., А Арешонков В. В., А Атаманчук В. М., Весельський В. К., Іщенко А. В., Юсупов В. В. Криміналістика : мультимедійний підручник. Київ : НАВС, 2015. URL: https://arm.naiau.kiev.ua/books/kruminalist/info/autors.html (дата звернення: 24.03.2021).

30. Щербаковський М. Г. Тактика проведення судових експертиз : лекція для усіх форм навчання / Національний ун-т внутр. справ. Харків, 2004. 60 с.

31. Щербаковський М. Г. Проведення та використання судових експертиз у кримінальному провадженні : монографія. Харків : В деле, 2015. 560 с. 
32. Шмонин А. В. Понятие и структура криминалистического обеспечения расследования преступлений. Труды Академии управления МВД России. 2010. № 1 (3). С. 3-8.

33. Бишевець О. В. Використання спеціальних знань у доказуванні в кримінальних провадженнях. Вісник кримінального судочинства. 2015. № 2. C. 187-193. URL: https://vkslaw.knu.ua/images/verstka/2_2015_Bushevec.pdf. (дата звернення: 24.03.2021).

34. Лисиченко В. К., Циркаль В. В. Использование специальных знаний в следственной и судебной практике : учеб. пособие. Киев : изд-во при КГУ, 1987. 100 с.

35. Лисиченко В. К. Использование данных естественных и технических наук в следственной и судебной практике : учеб. пособие. Киев : Вища школа, 1979. 88 с.

36. Ковбаса В. М. Криміналістична характеристика спеціальних знань. Науковий вісник Дніпропетровського державного університету внутрішніх справ. 2014. № 2. С. 224229.

37. Кравченко О. А. Застосування спеціальних знань під час збирання, дослідження та використання речових доказів : автореф. дис. ... канд. юрид. наук / Класичний приватний університет. Запоріжжя, 2012. 20 с.

38. Про судову експертизу : Закон України від 25.02.1994 № 4038-XII. URL: https://zakon.rada.gov.ua/laws/show/4038-12\#Tехt (дата звернення: 24.03.2021).

39. Бірюков В. В., Коваленко В. В., Бірюкова Т. П., Ковальов К. М. Криміналістичне документознавство : практ. посіб. / за заг. ред. В. В. Бірюкова. Київ : вид-во Паливода А. В., 2007. 332 с.

40. Тонков Е. Е., Каторгина Н. П. Понятие и признаки специальных знаний в конституционном судопроизводстве. Вестник ВГУ. Серия: Право. 2016. № 4. C. 54-66. DOI: https://doi.org/10.33766/2524-0323.89.54-62.

URL: https://www.researchgate.net/publication/338682006_PONATIE_I_PRIZNAKI_SPECIALNYH_Z NANIJ_V_KONSTITUCIONNOM_SUDOPROIZVODSTVE (дата звернення: 24.03.2021).

\section{References}

1. Lazebnyi, A. M. (2016). Rol spetsialnykh znan u kryminalnomu sudochynstvi Ukrainy. Mizhnarodnyi yurydychnyi visnyk: zbirnyk naukovykh prats Natsionalnoho universytetu derzhavnoi podatkovoi sluzhby Ukrainy [The role of special knowledge in criminal proceedings of Ukraine. International Legal Bulletin: collection of scientific works of the National University of the State Tax Service of Ukraine]. № 2 (4). S. 23-29 [in Ukrainian].

2. Kotsiuba, S. A., Chaplynskyi, K. O. (2018). Osoblyvosti vykorystannia spetsialnykh znan u kryminalnykh provadzhenniakh. Naukovyi visnyk Dnipropetrovskoho derzhavnoho universytetu vnutrishnikh sprav. [A special vicoristan of special children's knowledge at the romantics of the weddings. Science in the Day-Propetrovsic Power University]. Spetsvyp. № 1 (91) «Protydiia narkozlochynnosti v Ukraini ta u sviti: problemy ta shliakhy yikh vyrishennia». S. 57-61. URL: http://er.dduvs.in.ua/bitstream/123456789/1863/1/3.pdf (data zvernennia: 24.03.2021) [in Ukrainian].

3. Shcherbakovskyi, M. H. (2018). Sutnist, struktura ta tsili vykorystannia spetsialnykh znan u sudochynstvi. Teoriia ta praktyka sudovoi ekspertyzy i kryminalistyky [The essence, structure and objectives of using special knowledge in legal proceedings. Teoria and Practice of Forensic Expertise and Criminalistics]. № 18. S. 184-193. DOI: https://doi.org/10.32353/khrife.2018.20 [in Ukrainian].

4. Hribov, M. (2019). Poniattia ta pravove rehuliuvannia vykorystannia spetsialnykh znan, umin i navychok u kryminalnomu provadzhenni [Understands that legal regulating of the Vikoristan special known, the mind of the stalcills at the critically veiled]. Naukovyi visnyk Natsionalnoi akademii vnutrishnikh sprav. № 1(110). S. 13-21. DOI: https://doi.org/10.33270/01191101.13 [in Ukrainian].

5. Taranova, A. (2019). Formy vykorystannia spetsialnykh znan u rozsliduvanni nenalezhnoho vykonannia profesiinykh oboviazkiv medychnym abo farmatsevtychnym 
pratsivnykom. Pidpryiemnytstvo, hospodarstvo i parvo [Forms of use of special knowledge in investigating improper performance by a medical or pharmaceutical worker. Entrepreneurship, economy and law]. № 10. S. 198-203. DOI: https://doi.org/10.32849/2663-5313/2019.10.34 [in Ukrainian].

6. Lukianchykov, Ye. D., Lukianchykov, B. Ye., Petriaiev, S. Yu. (2019). Vykorystannia spetsialnykh znan u kryminalnomu provadzhenni. Visnyk NTUU «KPI». Politolohiia. Sotsiolohiia. Pravo. [Use of special knowledge in criminal proceedings. Bulletin of NTUU «KPI». Political science. Sociology. Right]. № 4 (44). S. 125-130. DOI: https://doi.org/10.20535/23085053.2019.4(44).199742.9 [in Ukrainian].

7. Piliukov, Yu. (2019). Vykorystannia spetsialnykh znan u kryminalnykh provadzhenniakh. Aktualni problemy pravoznavstva [Use of special knowledge in criminal proceedings. Actual problems of law]. № $4(20)$. S. 240-245. DOI: https://doi.org/10.35774/app2019.04.240 [in Ukrainian].

8. Shramko, O. (2019). Vydy spetsialnykh znan, shcho vykorystovuiutsia pid chas rozsliduvannia koruptsiinykh zlochyniv. Aktualni problemy pravoznavstva [Types of special knowledge used during the investigation of corruption crimes. Actual problems of jurisprudence]. № 2. S. 175-180. URL: http://appj.wunu.edu.ua/index.php/appj/article/view/693 (data zvernennia: 24.03.2021) [in Ukrainian].

9. Marushev, A. D. (2020). Pryntsypy zastosuvannia spetsialnykh znan u kryminalnomu provadzhenni. Aktualni problemy derzhavy i prava [Principles of application of special knowledge in criminal proceedings. Actual problems of the state and law]. № 86. S. 139-144. DOI: https://doi.org/10.32837/apdp.v0i86.2424 [in Ukrainian].

10. Vuima, A. H. (2020). Poniattia, sutnist ta formy spetsialnykh znan, shcho vykorystovuiutsia pid chas rozsliduvannia vbyvstv [Concepts, essences and forms of special knowledge used in homicide investigations]. Visnyk Luhanskoho derzhavnoho universytetu vnutrishnikh sprav imeni E. O. Didorenka. № 1 (89). S. 54-62 [in Ukrainian].

11. Popovych, I. M. (2019). Problemni pytannia pryznachennia ta provedennia sudovoi ekspertyzy v hospodarskomu sudochynstvi. Teoriia ta praktyka sudovoi ekspertyzy i kryminalistyky [Problematic issues of appointment and conduct of forensic examination in economic proceedings. Theory and practice of forensic examination and forensics]. № 20. S. 190-206. DOI: https://doi.org/10.32353/khrife.2.2019.14 [in Ukrainian].

12. Nadizhko, M. M. (2020). Vykorystannia spetsialnykh znan u sudovo-ekspertnii diialnosti: teoretyko-pravovi aspekty. Kryminalistychnyi visnyk [Use of special knowledge in forensic activities: theoretical and legal aspects. Forensic bulletin]. № 33 (1). S. 25-36. DOI: https://doi.org/10.37025/1992-4437/2020-33-1-25 [in Ukrainian].

13. Bourne L. E. Jr., Kole J. A., Healy A. F. Expertise: defined, described, explained. Front. Psychol. 2014. № 5. 186 p.

14. Grundmann R. The Problem of Expertise in Knowledge Societies. Minerva. 2017. № 55. P. 25-48. DOI: https://doi.org/10.1007/s11024-016-9308-7.

15. Pashutina, O. S., CHebotareva, I. N. (2017). Ispol'zovanie znanij svedushchih lic pri osushchestvlenii zashchity po ugolovnym delam: zakonodatel'nyj, doktrinal'nyj i pravoprimenitel'nyj aspekty. Izvestiya YUgo-Zapadnogo gosudarstvennogo universiteta [The use of knowledge of knowledgeable persons in the implementation of criminal protection: legislative, doctrinal and law enforcement aspects. News of Southwest State University]. № 21 (3). S. 155-166 [in Russian].

16. Koval I., Koval M., Frantsuz A., Koucherets D., Shpiliarevych V. Tactical Features of Use of Special Knowledge in the Investigation of Torture Committed by Members of the National Police of Ukraine. Journal Of Advanced Research In Law And Economics. 2019. № 10 (1). P. $263-$ 273. DOI: https://doi.org/10.14505//jarle.v10.1(39).27.

17. Littlejohn C. Truth, knowledge, and the standard of proof in criminal law. Synthese. 2020. № 197. P. 5253-5286. DOI: https://doi.org/10.1007/s11229-017-1608-4. 
18. Swan R. H., Plummer K. J., West R. E. Toward functional expertise through formal education: identifying an opportunity for higher education. Education Tech Research Dev. 2020. № 68 (5). P. 2551-2568. DOI: https://doi.org/10.1007/s11423-020-09778-1.

19. Kovalenko, V. V. (2007). Zastosuvannia naukovo-tekhnichnykh zasobiv spetsialistamy pry provedenni slidchykh dii : monohrafiia [The stagnation of the science-technical specialists in the special forces at the time of the past : monograph]. Luhansk : RVV LDUVS. $208 \mathrm{~s}$. [in Ukrainian].

20. Velykyi tlumachnyi slovnyk suchasnoi ukrainskoi movy [Large glossary of modern Ukrainian language] / za zah. red. V. T. Busel. Kyiv, Irpin : Perun, 2005. 1728 s. [in Ukrainian].

21. Slovnyk ukrainskoi movy online. Tomy 1-11. URL: https://services.ulif.org.ua/expl/Entry/index?wordid=37249\&page=1168 (data zvernennia: 24.03.2021) [in Ukrainian].

22. Eisman, A. A. (1967). Zaklyuchenie eksperta. Struktura i nauchnoe obosnovanie [Expert's opinion. Structure and scientific justification]. M. : YUrid. lit., 152 s. [in Russian].

23. Sokolovskij, Z. M. (1969). Ponyatie special'nyh znanij. Kriminalistika i sudebnaya ekspertiza [The concept of special knowledge. Criminalistics and judicial ecpertis]. № 6. S. 199-205 [in Russian].

24. Saltevskyi, M. V. (2005). Kryminalistyka (u suchasnomu vykladi) : pidruchnyk [Criminalistics (in modern presentation) : tutorial]. Kyiv : Kondor. 588 s. [in Ukrainian].

25. Kuzmichov, V. S., Pyrih, I. V. (2008). Vykorystannia spetsialnykh znan pry rozsliduvanni rozkradan vantazhiv na zaliznychnomu transporti : monohrafiia [Use of special knowledge in the investigation of cargo thefts by rail : monograph]. Dnipropetrovsk : Lira LTD. 168 s. [in Ukrainian].

26. Logvinec, E. A. (2010). O sushchnosti special'nyh znanij. Nauchnye vedomosti BelGU. Seriya: Filosofiya. Sociologiya. Pravo. [On the essence of special knowledge. BelSU scientific records. Series: Philosophy. Sociology. Right]. Vyp. 12 № 8 (79).S. 98-102.URL: http://dspace.bsu.edu.ru/bitstream/123456789/3627/1/Logvinets\%20E_A_To\%20the\%20essence.pd f (data zvernennia: 24.03.2021) [in Russian].

27. Sviridov, D. A. (2013). K voprosu o sushchnosti special'nyh znanij pri rassledovanii prestuplenij. Uchenye zapiski Tavricheskogo nacional'nogo universiteta im. V. I. Vernadskogo. Seriya: YUridicheskie nauki [On the question of the essence of special knowledge when investigating crimes. Scientists of the Tauride National University V.I. Vernadsky. Series: Legal $\begin{array}{llll}\text { Sciences].T. } 26(65) \text { № } 1 . & \text { S. 332-337. URL: }\end{array}$ http://www.juris.vernadskyjournals.in.ua/journals/2013/1_2013/54.pdf (data zvernennia: 24.03.2021) [in Russian].

28. Shepitko, V. Yu. (2014). Problemy vykorystannia spetsialnykh znan kriz pryzmu suchasnoho kryminalnoho sudochynstva v Ukraini. Sudova ekspertyza [Problems of using special knowledge through the prism of modern criminal justice in Ukraine. Judicial examination]. № 1. S. 11-18 [in Ukrainian].

29. Kryminalistyka : multymediinyi pidruchnyk [Forensics : multimedia tutorial] / O. O. Alieksieiev, V. V. Areshonkov, V. M. Atamanchuk, O. O. Vakulyk, V. K. Veselskyi, A. V. Ishchenko, V. V. Yusupov. Kyiv: $2015 . \quad$ NAVS, https://arm.naiau.kiev.ua/books/kruminalist/info/autors.html (data zvernennia: 24.03.2021) [in Ukrainian].

30. Shcherbakovskyi, M. H. (2004). Taktyka provedennia sudovykh ekspertyz : lektsiia dlia usikh form navchannia [Tactics for conducting litigation: lecture for all forms of study] / Natsionalnyi un-t vnutr. sprav. Kharkiv. 60 s. [in Ukrainian].

31. Shcherbakovskyi, M. H. (2015). Provedennia ta vykorystannia sudovykh ekspertyz u kryminalnomu provadzhenni : monohrafiia [Conducting and using judicial examinations in criminal proceedings : monograph]. Kharkiv : V dele. 560 s. [in Ukrainian].

32. SHmonin, A. V. (2010). Ponyatie i struktura kriminalisticheskogo obespecheniya rassledovaniya prestuplenij. Trudy Akademii upravleniya MVD Rossii [The concept and structure of 
criminalistic investigation of crimes. Proceedings of the Academy of Department of the Ministry of Internal Affairs of Russia]. № 1 (3). S. 3-8 [in Russian].

33. Byshevets, O. V. (2015). Vykorystannia spetsialnykh znan u dokazuvanni v kryminalnykh provadzhenniakh [Use of special knowledge in evidence in criminal proceedings]. Visnyk kryminalnoho sudochynstva. № 2. S. 187-193. URL: https://vkslaw.knu.ua/images/verstka/2_2015_Bushevec.pdf (data zvernennia: 24.03.2021) [in Ukrainian].

34. Lisichenko, V. K., Cirkal', V. V. (1987). Ispol'zovanie special'nyh znanij v sledstvennoj i sudebnoj praktike : ucheb. posobie [The use of special knowledge in investigative and judicial practice : studies allowance]. Kiev : izd-vo pri KGU. 100 s. [in Russian].

35. Lisichenko, V. K. (1979). Ispol'zovanie dannyh estestvennyh i tekhnicheskih nauk v sledstvennoj i sudebnoj praktike : ucheb. posobie [The use of these natural and technical sciences in investigative and judicial practice : studies allowance]. Kiev : Vishcha shkola. 88 s. [in Russian].

36. Kovbasa, V. M. (2014). Kryminalistychna kharakterystyka spetsialnykh znan. Naukovyi visnyk Dnipropetrovskoho derzhavnoho universytetu vnutrishnikh sprav [The characteristic of special known is critical. Scientific Bulletin of the Dnipropetrovsk State University of Internal Affairs]. № 2. S. 224-229 [in Ukrainian].

37. Kravchenko, O. A. (2012). Zastosuvannia spetsialnykh znan pid chas zbyrannia, doslidzhennia ta vykorystannia rechovykh dokaziv [Applying special knowledge during harvesting, research and use of real evidence] : avtoref. dys. ... kand. yuryd. nauk / Klasychnyi pryvatnyi universytet. Zaporizhzhia. $20 \mathrm{~s}$. [in Ukrainian].

38. Pro sudovu ekspertyzu : Zakon Ukrainy vid 25.02.1994 № 4038-12 [About the judicial examination : the Law of Ukraine dated 25.02.1994 No. 4038-12]. URL: https://zakon.rada.gov.ua/laws/show/4038-12\#Text (data zvernennia: 24.03.2021) [in Ukrainian].

39. Biriukov, V. V., Kovalenko, V. V., Biriukova, T. P., Kovalov, K. M. (2007). Kryminalistychne dokumentoznavstvo : prakt. posib. [Forensic records keeping : practical guide]. I za zah. red. V. V. Biriukova. Kyiv : vyd-vo Palyvoda A. V. 332 s. [in Ukrainian].

40. Tonkov, E. E., Katorgina, N. P. (2016). Ponyatie i priznaki special'nyh znanij v konstitucionnom sudoproizvodstve. Vestnik VGU. Seriya: Pravo. [The concept and signs of special knowledge in constitutional proceedings. Bulletin VSU. Series: Law]. № 4. S. 54-66. DOI: https://doi.org/10.33766/2524-0323.89.54-62.

URL: https://www.researchgate.net/publication/338682006_PONATIE_I_PRIZNAKI_

SPECIALNYH_ZNANIJ_V_KONSTITUCIONNOM_SUDOPROIZVODSTVE (data zvernennia: 24.03.2021) [in Russian].

\author{
Kovalov Kostiantyn, \\ Deputy Director \\ (State Scientific Research Forensic Centre, \\ MIA of Ukraine, Kyiv) \\ ORCID: https://orcid.org/0000-0003-1964-9283
}




\section{SPECIAL KNOWLEDGE IN FORENSIC EXAMINATION DETERMINATION OF THE LIMITATION PERIOD OF THE DOCUMENT}

The purpose of the article is to formulate a conceptual vision of improving the scientific and methodological foundations of the application of special knowledge in the field of forensic documentation through the formation within the forensic technical examination of documents of a new expert specialty - determining the statute of limitations (index 2.4). The reliability of the obtained results and conclusions is ensured by the use of a set of general scientific research methods. In particular, with the help of the historical-legal method the scientific opinion on the content of special knowledge in retrospect is investigated; system-analytical - generalized scientific approaches to highlighting the main objectives of the use of special knowledge; system-structural - the range of special knowledge in the field of forensic document science, which should be possessed by an expert documentologist, is defined, the definition of «special knowledge in the field of forensic document science» is formulated; system-functional-formulated a conceptual vision of ways to improve the scientific and methodological foundations of the application of special knowledge in the field of forensic document science. In addition, for practical implementation, such forms of knowledge as concepts, laws, hypotheses, theories are used, which allow to apply them further, receiving scientific approbation. The definition of «special knowledge in the field of forensic document science» is formulated and the necessity of creation within the limits of forensic technical examination of documents of a new expert specialty - definition of prescription of the document (index 2.4) is scientifically substantiated. As a result of retrospective analysis of scientific opinion on the content of special knowledge, it is stated that the discussion on this subject continues, determining the expediency of determining special knowledge by areas of application. A wide range of special knowledge in the field of forensic document science is outlined, which should be possessed by an expert document maker, forming a separate category of knowledgeable persons. Scientifically substantiated, given the amount of special knowledge that document experts should have, promising areas of expanding the possibilities of forensic technical examination of documents, providing for the creation of a new expert specialty - determining the statute of limitations (index 2.4) and initiating new approaches to forensic training.

Key words: forensic examination; forensic technical examination of documents; expert specialty; determination of prescription of documents; forensic document science; expertise; special knowledge in the field of forensic document science; forensic expert; expert documentologist.

Надіслано до редколегії 08.04.2021 Рекомендовано до публікації 16.04.2021 
DOI: https://doi.org/10.32366/2523-4269-2021-75-2-153-160

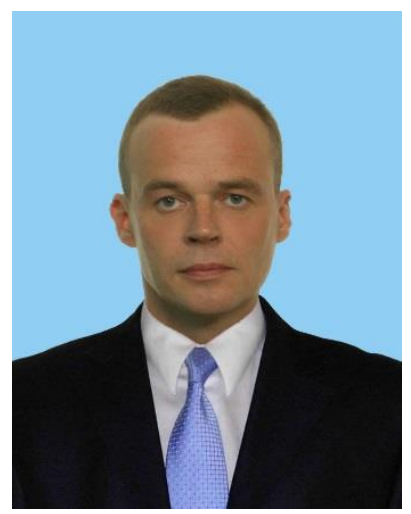

\section{Кубарсв Іван Володимирович,} кандидат юридичних наук, доцент (Донеиький державний університет внутрішніх справ, м. Кривий Ріг)

ORCID: https://orcid.org/0000-0003-1053-9758

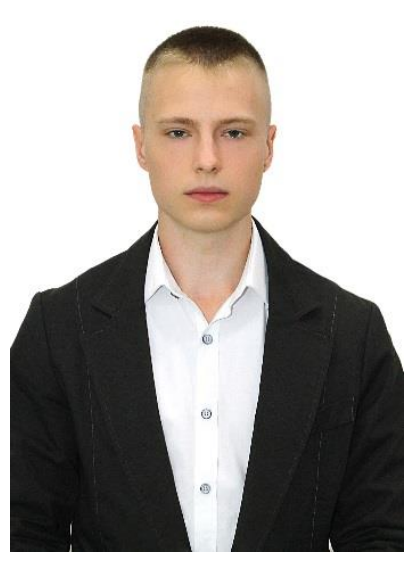

Барган Сергій Сергійович, магістр права (Донеиький державний університет внутрішніх справ, м. Кривий Ріг)

ORCID: https://orcid.org/0000-0002-1706-0355

\section{ТАКТИКА ДОПИТУ: ЗАКОРДОННИЙ ДОСВІД}

У статті розглянуто закордонний досвід проведення допиту як дієвого механізму отримання повних $i$ достовірних фактичних даних на досудовому розслідуванні. Розкрито зміст гуманістичного та наративного підходів, які вважаються провідними під час розробки нових $i$ вдосконаленні наявних прийомів допиту та спрямовані забезпечити належне виконання завдань кримінального провадження. За результатами дослідження здійснено спробу виокремити криміналістичні особливості моделей допиту, щэо застосовуються в зарубіжних краӥнах.

Ключові слова: тактика допиту; процесуальне інтерв'ю; модель РЕАСЕ; модель KREATIV; криміналістика.

Постановка проблеми. Вивчення зарубіжного досвіду щодо застосування прийомів і методів розслідування злочинів, а також доцільності їх упровадження у вітчизняну правоохоронну практику $\epsilon$, як відомо, одним 3 наукових завдань криміналістики. Це, безумовно, стосується і допиту як найбільш розповсюдженої слідчої (розшукової) дії. У зарубіжних дослідженнях у цьому напрямку констатується відчутне зниження рівня ефективності дотримання прав і свобод людини в межах кримінального провадження внаслідок застосування маніпулятивних моделей допиту, спрямованих на отримання зізнання від допитуваної особи. Зокрема, британський професор із судової психології Р. Булл указує на необхідність негайного переходу від примусового характеру комунікації на допиті до фундаментальної лібералізації процесуального спілкування [1, с. 181]. Про актуальність дослідження також свідчить доповідь спеціального доповідача Організації Об’єднаних Націй (далі - OОН) з питань катувань X. Мендеса (J. Mendez) у 2016 році, який вимагав прийняти

(C) Кубарєв Іван Володимирович,

Барган Сергій Сергійович, 2021 
універсальні методи проведення допиту, не заснованого на примусі, закликавши державичлени ООН якнайшвидше розробити міжнародні керівні принципи та настанови щодо проведення непримусових допитів і пов'язаних з ними гарантій, унаслідок чого вже через два роки відбулися перші засідання спеціально створеної Редакційної групи для обговорення змісту протоколів допиту, не пов'язаного з примусом [2, с. 35; 3]. Але, наскільки нам відомо, остаточного рішення з цього приводу досі не прийнято.

Аналіз останніх досліджень і публікацій. На проблемах домінування обвинувального підходу під час проведення допиту наголошували такі зарубіжні дослідники, як Р. Булл, Е. Гайзельмен, Г. Гейдон, С. Кассін, Р. Мілн, С. Сукара, Д. Уолш, Р. Фішер, М. Шоллум та інші. До того ж більшість із зазначених правників стверджують, що розробка нових моделей проведення допиту повинна грунтуватися на позиціях гуманізму з обов'язковим урахуванням наукових досягнень у галузі криміналістики, психології і психолінгвістики. Водночас у вітчизняній науці (В. П. Бахін, А. Ф. Волобуєв, В. О. Коновалова, Л. Д. Удалова, В. Ю. Шепітько та ін.) панівною $є$ думка про допустимість психологічного впливу на допитуваного, у тому числі завдяки тактичним прийомам створення перебільшеного уявлення про наявні докази або поінформованість слідства, організації промовок, непрямого допиту тощо. Тому значний інтерес становлять наукові підходи закордонних фахівців до тактичних прийомів допиту. Проте їх порівнянню i подальшому вдосконаленню на цій підставі достатньої уваги не приділено, а досвід зарубіжних науковців у зазначеному аспекті висвітлено фрагментарно.

Формування цілей статті. Метою дослідження є ознайомлення вітчизняних фахівців 3 теоретичними розробками закордонних криміналістів щодо тактики допиту на досудовому розслідуванні та визначення тенденцій їх розвитку.

Виклад основного матеріалу. Із позицій психології допит характеризується наявністю процесуальної форми комунікації (спілкування) між суб'єктом, який веде допит (слідчим), і допитуваним (потерпілим, свідком, підозрюваним) шляхом отримання зворотного зв'язку від останнього. У цьому питанні слушною $є$ позиція В. Ю. Шепітька, який визначає допит як складний інформаційно-психологічний процес спілкування (курсив наш. - I. К., С. Б.) осіб, котрі беруть у ньому участь, що спрямований на отримання інформації про відомі допитуваному факти, необхідні для виконання завдань кримінального провадження [4, с. 73]. Комунікативна складова допиту обумовлена тим, що без спілкування та взаємодії між учасниками кримінального провадження неможливо отримати достовірні та повні за обсягом фактичні дані про кожен елемент предмета доказування, у тому числі відомості про мотиви, мету та причини вчинення кримінального правопорушення. Водночас, як справедливо зазначають фахівці, інформація, яка зафіксована в пам'яті допитуваного під час сприйняття тих чи інших предметів або явищ, у процесі допиту відтворюється і передається слідчому у формі відповідних мовних i фонетичних конструкцій, а також невербальних засобів спілкування, що вказує на пізнавальну та когнітивну складові допиту [5, с. 352]. Схожих поглядів дотримується Р. К. Гітінов, оскільки допит за своїм психологічним і гносеологічним змістом є видом процесуального міжособистісного спілкування та обміну інформацією, що відбувається в діалоговій формі за допомогою мовних і немовних (невербальних) комунікацій головних дійових осіб [6, с. 165]. Наведені аспекти допиту обумовлюють доцільність використання як психологічних, так і лінгвістичних підходів під час розробки розробці непримусових моделей допиту.

Показовим $є$ те, що більшість зарубіжних практиків намагається обмежити термін «допит» у вживанні, адже він тісно пов'язаний з обвинувальним підходом, а також примусовою і насильницькою конотацією. Натомість вони пропонують використовувати психологічно нейтральне поняття «процесуальне інтерв'ю», яке семантично спрямоване на отримання інформації у ході розмови й опитування, що за форматом наближається до звичайного інтерв'ю. Наприклад, вирішуючи завдання щодо усунення недоліків допиту, на початку 90-х років дослідницька група Міністерства внутрішніх справ Великобританії на чолі iз британським юристом Р. Буллом (R. Bull) обгрунтували модель інтерв'ювання РЕАСЕ, 
тактика якої спирається на здобутки когнітивної психології [7, с. 40]. Абревіатура РЕАСЕ використовується для позначення п'яти етапів допиту (назви подано мовою оригіналу англійською. - I. K, C. Б.), зміст кожного з яких розкрито далі.

1. «Planning and preparation»- планування і підготовка, які є основоположними для продуктивного інтерв’ювання. Планування передбачає вивчення доступної інформації про особу допитуваного та особливості вчиненого кримінального правопорушення, визначаючи ключові проблеми та цілі.

2. «Engage and explain»- налагодження психологічного контакту та роз'яснення теми допиту. При цьому важливим елементом взаємодії, на думку розробників, є підтримання етичного рівня спілкування, а також уміння пристосовуватися до змін обставин бесіди. Рекомендується для формування правильних відносин перед початком допиту налагодити 3 допитуваним контакт. До того ж для підвищення рівня довіри варто повідомити про причини проведення інтерв'ю та оголосити його мету.

3. «Account clarification and challenge»- вільний виклад інформації допитуваним про обставини злочину. Етап спрямований на отримання від особи максимально повної деталізації обставин подій, що відбулися. Проте, як вказує Р. Булл (R. Bull), роль слідчого не $\epsilon$ цілком пасивною, оскільки для уточнення певних відомостей він повинен уміти підтримати бесіду, спрямувати іiі в необхідну сторону, а також сприяти відновленню в пам'яті забутої інформації $[8$, с. 7]. Після завершення вільної розповіді допитуваному нерідко пропонується повідомити окрему інформацію, але зі зміною хронологічного порядку чи з позиції іншого учасника події злочину. Також допускається, щоб слідчий по завершенню розповіді допитуваної особи продемонстрував ій знайдені протиріччя або невідповідності у щойно отриманих відомостях.

4. «Closure»- завершення. На цьому етапі дуже важливо, щоб усі учасники допиту усвідомили інформацію, яка була отримана під час розмови, а також те, які наслідки вона матиме в майбутньому. Допитуваному має бути надана можливість поставити будь-які питання або дати додаткові пояснення. Важливо, щоб на завершення допиту інтерв'юер підсумував результати того, що сказав допитуваний.

5. «Evaluation»- аналіз й оцінка інтерв'ю. Після завершення всіх етапів співбесіди необхідно оцінити отримані результати в цілому. Насамперед аналізу підлягають досягнуті цілі, на підставі чого визначається необхідність проведення інших досліджень або додаткового опитування. Далі відбувається співставлення отриманих відомостей 3 уже наявними фактичними даними, отриманих у ході інших слідчих заходів.

У такій техніці збору інформації будь-які форми обману не матимуть вирішального значення, оскільки кожне слово надалі важливо перевірити й порівняти з іншими доказами. Попри те, що деякі науковці критикують цей підхід за надмірну «м'якість», варто зазначити, що в одному 3 американських досліджень, проведеному в 2010 році, установлено, що застосування слідчими «жорстоких» і маніпулятивних методів нерідко призводить до значно гірших наслідків, у тому числі й до визнання доказів у суді недопустимими, руйнуючи побудовану схему обвинувачення [9, с. 12]. Тому за результатами аналізу кількості та якості фактичних даних, отриманих завдяки застосуванню моделі РЕАСЕ, консультант американської поліції М. Шоллум зробила висновок, що така модель, незважаючи на зовнішню «м'якість», демонструє значне зростання рівня неупередженості слідчого, уникаючи виникнення передчасних суджень про винуватість чи невинуватість особи, що підвищує якість отриманих показань [10, с. 33].

Таким чином, у моделі РЕАСЕ вперше було розглянуто допитувану особу 3 нейтральних позицій. Ця модель має на меті отримання достовірної інформації про подію злочину без маніпулятивних тактик, упередженості інтерв'юера про винуватість конкретної особи чи прагнень іiі звинуватити під час опитування. Особливість моделі полягає у використанні науково обгрунтованих методів, до яких належать вільна розповідь, когнітивне інтерв’ю та управління бесідою. Для їх реалізації інтерв’юери користуються прийомами активного слухання, використання пауз і тиші, відкритих запитань, активізації пам'яті тощо. 
Нейтральні прийоми опитування, як справедливо зазначає професор судової психології C. Сукара (S. Soukara), дозволяють досягти позитивних результатів, що полягають у: точному відтворенні інформації, яка зберігається в пам'яті допитуваного; збільшенні обсягу повідомленої інформації; забезпеченні якості показань внаслідок відповідей на питання відкритого типу; створенні зворотного зв'язку з допитуваним; збереженні рівня добровільних зізнань порівняно з усталеними методами допиту, але знижуючи ризик помилок [11, с. 907].

Сукупність когнітивних, комунікативно-прагматичних і мовних аспектів допиту передбачає використання комплексного підходу для отримання i, що найголовніше, осмислення інформації, яка надійшла від допитуваного. Для аналізу висловлюваних мовних одиниць закордонні правоохоронці звертаються до застосування наративної практики інтерв'ю з подальшим лінгвістичним аналізом його змісту. Наративний підхід полягає у проведенні дискурсу, завдяки якому особа усвідомлює та передає у формі розповіді власний досвід, має на меті сфокусуватися на подробицях як події в цілому, так і на іiі окремих елементах, що відіграє важливе значення для розкриття і розслідування злочинів. Весь розумовий процес за такого підходу здійснює допитувана особа, оскільки спілкування відбувається у вигляді системи «TED» (tell, explain, describe) - розкажи, поясни, опиши, тобто має характер вільної розповіді [12, с. 116]. Тому спочатку слідчий не допускає використання запитань, конструюючи свої висловлювання на зразок «розкажіть мені все, що відбувалося в той день» [1, с. 181]. Водночас інтеррогатив (відкриті запитання) виступає допоміжним мовним актом, який слугує для доповнення висловленої інформації на наступному етапі. Поряд з інтеррогативом використовуються й інші види категорій, наприклад: репрезентативні (повідомлення, переконання, твердження, осуд, прогнозування, визнання, опис); директивні (прохання, порада, попередження, загроза, застереження, вимога); коміссивні (обіцянка, гарантії); експресивні (подяка, захоплення) [13, с. 5].

У лінгвістичному значенні подальший аналіз отриманих показань залежить від хронологічного викладу історії з урахуванням того, як побудовані ії складові елементи. Так, В. Лабов і Дж. Валецькі (William Labov \& Joshua Waletzky) запропонували стандартну лінгвістичну основу для наративного аналізу. Використання цієї структури в аналізі може допомогти виділити структуру інформації, поділяючи розповідь на взаємопов'язані компоненти: 1) анотація (короткий виклад розповіді); 2) орієнтація на час, місце, осіб та їхню активність; 3) дії, що ускладнюють і надають динаміки ключовим подіям розповіді; 4) оцінка найбільш важливих відомостей; 5) осмислення минулих подій розповіді в умовах теперішнього часу $[14$, с. 18$]$.

Спроби застосування наративного підходу до тактики допиту останнім часом спостерігаються й у вітчизняній криміналістиці. Зокрема, зазначається, що у спрощеній формі структурування почутого опису подій відбувається за фрагментами: 1) стадія до вчинення кримінального правопорушення (преамбула події, початок дня, знайомство з іншими людьми); 2) стадія, що передувала злочинному посяганню (події i дії, які розгортаються перед вчиненням злочинних дій); 3) кримінальна стадія злочину (безпосереднє вчинення дій злочинного характеру); 4) посткримінальна стадія (дії, які здійснені після вчинення злочину) $[15$, с. 203]. Наратив допитуваного дозволяє визначити, за яких умов та який досвід був ним засвоєний. До того ж наявність відповідних маркерів у розповіді демонструє рівень інтеграції події, що відбулася, до структури особистісного досвіду та його усвідомлення [16, с. 29].

Нині модель РЕАСЕ успішно застосовується у Великобританії, Австралії, Новій Зеландії, Норвегії, а останнім часом - у Канаді. Інші країни - В’єтнам, Індонезія, Сінгапур, Малайзія, Республіка Ірландія - активно розглядають світову практику для поліпшення власних методик досудового розслідування [17, с. 20-21]. Незважаючи на значні досягнення у лібералізації допиту, які запропоновано в моделі РЕАСЕ, та її безумовне схвалення Бюро 3 демократичних інститутів і прав людини Організації з безпеки і співробітництва в Свропі (далі - ОБСЄ), в Україні вона залишається поза увагою правників.

Дещо інші підходи до проведення допиту рекомендуються правоохоронцями США. Там здебільшого використовують тактику REID (пряма конфронтація, відхилення, зверхність, 
перетворення заперечень на підтвердження, прояв емпатії, опрацювання різних сценаріїв, «альтернативні питання», повторення, фіксація в письмовій формі), а також 15 стратегій Кальбфляйша (залякування, ситуаційна марність зусиль, дискомфорт і полегшення, блеф, спонукання, мінімізація, протиріччя, змінена інформація, блокування у захисті, саморозкриття, виявлення сигналів обману, занепокоєння, збереження статус-кво, прямий підхід, мовчання), які є обвинувальними за своїм змістом та мають на меті отримати від особи зізнання, а не зібрати повну та об'єктивну інформацію про подію злочину [18, с. 470].

Більш сучасним варіантом альтернативного проведення допиту є модель KREATIV, яка розроблена в Норвегії на основі британської системи PEACE. Акронім KREATIV відображає основоположні цінності та принципи цього методу, зокрема (назви наводяться мовою оригіналу - норвезькою. - I. К., С. Б.):

Kommunikasjon - спілкування;

Rettssikkerhet - верховенство права;

Etikk og Empati - етичність;

Aktiv bevisstgjøring - активна свідомість;

Tillit gjennom åpenhet - довіра через відкритість;

Informasjon - змістовність інформації;

Vitenskapeligforankring - науковість [20].

Норвезька поліція розглядає модель KREATIV як операціоналізм презумпції невинуватості. Хоча презумпція невинуватості регламентується як процесуальна гарантія, вона також $є$ основою для проведення ефективних допитів у вигляді інтерв'ю. Головна роль слідчого за норвезького підходу полягає в тому, щоб зібрати якомога більше точної та достовірної інформації, а не просто дізнатися про факт винуватості чи невинуватості особи [20, с. 184]. Особливістю моделі KREATIV, на відміну від британського підходу, є наявність дослідницької фази завдяки використанню принципів SUE (стратегічного використання доказів). Дослідницька фаза містить стратегічний і тактичний рівні. Стратегічний рівень полягає в поясненні допитуваним конкретних розмежованих тем, після чого слідчий ставить запитання для їх деталізації. На завершення розгляду окремого епізоду слідчий підсумовує ключові моменти того, що сказав допитуваний. Такий відокремлений аналіз подій, на думку закордонних фахівців, дозволяє почути більш змістовні відповіді, зрозуміти рівень обізнаності особи про зібрані докази в кримінальному провадженні, побачити наявність або відсутність стратегії протидії розслідуванню, передбачити подальшу перспективу розслідування. Тактичний рівень також має декілька етапів: 1) виявлення наявних доказів у кримінальному провадженні шляхом вивчення матеріалів справи (під час підготовки важливо розглядати як інформацію, пов'язану з обвинуваченням, так і ту інформацію, яка вказує на невинуватість допитуваного); 2) визначення всіх можливих пояснень потенційних доказів, особливу увагу звернено на альтернативні пояснення (усебічність версій виникнення тих або інших доказів протидіє «тунельному баченню» розслідуваного злочину); 3) усунення альтернативних пояснень (слідчий повинен ставити запитання так, щоб допитуваний не міг зрозуміти, які саме докази $\epsilon$ в поліції); 4) тактичне пред'явлення доказів допитуваному 3 подальшими запитаннями щодо пояснення певних подій [21, с. 4].

Висновки. Отже, однією із сучасних тенденцій у розвитку тактики допиту в зарубіжних країнах $є$ iї гуманізація. Нові техніки інтерв'ювання мають на меті допомогти органам досудового розслідування досягти низки позитивних результатів, зокрема: 1) отримання повної інформації про подію злочину, що зміцнює позицію державного обвинувачення в суді; 2) належне виконання завдань кримінального провадження (засудження підозрюваного або виправдання невинуватої особи, дотримання прав і свобод людини); 3) зростання поваги громадськості до професіоналізму органів поліції і суду, а також підвищення загальної довіри до правосуддя. Сучасні підходи до розробки моделей допиту зосереджені на його психологічних та когнітивних складових, у межах яких відбувається створення і підтримання належного рівня комунікації, що сприятиме повноті та об'єктивності показань допитуваного, оминаючи обвинувальний, примусовий чи нав'язливий підходи. Доцільність імплементації 
описаних моделей у вітчизняну слідчу практику вимагає подальших наукових досліджень, але наявність у них раціональних складових, на нашу думку, є беззаперечною.

\section{Список використаних джерел}

1. Bull R., Milne R. (2004). Attempts to improve the police interviewing of suspects. In G. D. Lassiter, Interrogations, confessions and entrapment. New York : Kluwer. P. 181-196.

2. Mary Schollum. Bringing PEACE to the United States: A Framework for Investigatve Interviewing. Police Chief Magazine. 2017. P. 30-37.

3. The Association for the Prevention of Torture. Universal Protocol for Investigative Interviewing and Associated Safeguards: Drafting Process Goes Ahead. URL: https://www.apt.ch/en/news_on_prevention/universal-protocol-investigative-interviewing-andassociated-safeguards-drafting/ (дата звернення: 11.03.2021).

4. Шепитько В. Ю. Теория криминалистической тактики : монография. Харьков : Гриф, 2002. 349 с.

5. Пясковський В. В., Чорноус Ю. М., Іщенко А. В. Криміналістика : підручник. Київ : Центр учбової літератури, 2015. 544 с.

6. Гитинов Р. К. Особенности расследования мошенничества в сфере автострахования : дисс. ... канд. юрид. наук. Уфа, 2017. 238 с.

7. Walsh, D. W., Milne R. Keeping the PEACE? A study of investigative interviewing practices in the public sector. Legal and Criminological Psychology. 2008. P. 39-57.

8. Bull, R. Investigative Interviewing. NewYork : Springer Science+Business Media. 2014. 259 p.

9. Kassin, S. M., et al. Police-induced confessions: risk factors and recommendations. Law and human behavior. 2010. P. 3-38.

10. Schollum, M. Bringing PEACE to the United States: A framework for investigative interviewing. The Police Chief. 2017. P. 30-37.

11. Soukara S. Investigative interviewing of suspects: the way forward. Crime in crisis. VII. Police and Policing during Crisis. 2017. P. 902-920.

12. Heydon, G. 2012, Helping the police with their enquiries: Enhancing the investigative interview with linguistic research. The Police Journal. Vol. 85. No. 2. P. 101-122.

13. Зайцева В. В. Когнитивные, коммуникативно-прагматические и языковые особенности допроса в юридическом дискурсе : автореф. дисс. ... канд. филолог. наук. Тамбов, 2011. $24 \mathrm{c}$.

14. Labov William and Joshua Waletzky. 1967. Narrative analysis. In J. Helm (ed.), Essays on the Verbal and Visual Arts. Seattle: U. of Washington Press. P. 12-44.

15. Шаповалов В. А. Методика психологической оценки достоверности показаний в юридической практике. Актуальні питання теорії та практики використання поліграфа. 2015. С. 198-218.

16. Назарук О. М. Метод наративу як проективний метод дослідження досвіду особистості. Сучасні напрями розвитку педагогічних та психологічних наук. 2015. С. 27-31.

17. Eliminating Incentives for Torture in the OSCE Region: Baseline Study and Practical Guidance. Organization for Security and Co-operation in Europe. 2020. 89 p.

18. Kalbfleisch P. J. (1994). The language of detecting deceit. Journal of Language and Social Psychology. No. 13 (4). P. 469-496.

19. From interrogations to investigative interviewing. The NCHR international department. Rule of law. $\quad$ P. 1-2. https://www.jus.uio.no/smr/english/about/id/docs/invest_int_concept_note_nov2019.pdf (дата звернення: 14.03.2021).

20. Barela S., Fallon M., Gaggioli G., Ohlin J. (Eds.), Interrogation and torture: Research on efficacy, and its integration with morality and legality. New York : Oxford University Press. 2020. $591 \mathrm{p}$. 
21. Jakobsen K. K. Tolkning i forbindelse med politiafhøring. Problemer og mulige løsninger. Tolking i offentlig sektor. Vol. 2, No. 1. 2015. P. 1-14.

\section{References}

1. Bull R., Milne R. Attempts to improve the police interviewing of suspects. In G. D. Lassiter, Interrogations, confessions and entrapment. New York : Kluwer. 2004. P. 181-196.

2. Mary Schollum. Bringing PEACE to the United States: A Framework for Investigative Interviewing. Police Chief Magazine. 2017. P. 30-37.

3. The Association for the Prevention of Torture. Universal Protocol for Investigative Interviewing and Associated Safeguards: Drafting Process Goes Ahead. URL: https://www.apt.ch/en/news_on_prevention/universal-protocol-investigative-interviewing-andassociated-safeguards-drafting/ (data zvernennia: 11.03.2021).

4. Shepitko, V. Yu. (2002). Teoriya kriminalisticheskoj taktiki : monografiya [Theory of Forensic Tactics : monograph]. Harkov : Grif. 349 s. [in Russian].

5. Piaskovskyi, V. V., Chornous, Yu. M., Ishchenko, A. V. (2015). Kryminalistyka : pidruchnyk [Criminalistics : Textbook]. Kyiv : Tsentr uchbovoi literatury. 544 s. [in Ukrainian].

6. Gitinov, R. K. (2017). Osobennosti rassledovaniya moshennichestva v sfere avtostrahovaniya : diss. ... kand. yurid. nauk [Features of the investigation of fraud in the field of auto insurance]. Ufa. 238 s. [in Russian].

7. Walsh, D. W., \& Milne, R. (2008). Keeping the PEACE? A study of investigative interviewing practices in the public sector. Legal and Criminological Psychology. P. 39-57.

8. Bull R. Investigative Interviewing. NewYork : Springer Science+Business Media. 2014. 259 p.

9. Kassin, S. M., et al. Police-induced confessions: risk factors and recommendations. Law and human behavior. 2010. P. 3-38.

10. Schollum, M. Bringing PEACE to the United States: A framework for investigative interviewing. The Police Chief. 2017. P. 30-37.

11. Soukara S. Investigative interviewing of suspects : the way forward. Crime in crisis. VII. Police and Policing during Crisis. 2017. P. 902-920.

12. Heydon, G. Helping the police with their enquiries: Enhancing the investigative interview with linguistic research. The Police Journal. 2012. Vol. 85. No. 2. P. 101-122.

13. Zajceva, V. V. (2011). Kognitivnye, kommunikativno-pragmaticheskie i yazykovye osobennosti doprosa v yuridicheskom diskurse : avtoref. diss. ... kand. filolog. nauk [Cognitive, Communicative-Pragmatic and Linguistic Peculiarities of Interrogation in Legal Discourse]. Tambov. 24 s. [in Russian].

14. Labov William and Joshua Waletzky. 1967. Narrative analysis. In J. Helm (ed.). Essays on the Verbal and Visual Arts. Seattle : U. of Washington Press. P. 12-44.

15. Shapovalov, V. A. (2015). Metodika psihologicheskoj ocenki dostovernosti pokazanij $\mathrm{v}$ yuridicheskoj praktike [Methodology for the psychological assessment of the reliability of testimony in legal practice]. Aktualni pitannya teorii ta praktyki vykoristannya poligrafa. S. 198-218 [in Russian].

16. Nazaruk, O. M. (2015). Metod naratyvu yak proektyvnyi metod doslidzhennia dosvidu osobystosti [The method of narrative as a projective method of studying the experience of personality]. Suchasni napriamy rozvytku pedahohichnykh ta psykholohichnykh nauk. S. 27-31 [in Ukrainian].

17. Eliminating Incentives for Torture in the OSCE Region: Baseline Study and Practical Guidance. Organization for Security and Co-operation in Europe. 2020. 89 p.

18. Kalbfleisch, P. J. (1994). The language of detecting deceit. Journal of Language and Social Psychology. No. 13 (4). P. 469-496.

19. From interrogations to investigative interviewing. The NCHR international $\begin{array}{lllll}\text { department. } & \text { Rule law. } & \text { P. 1-2. } & \text { URL: }\end{array}$ 
https://www.jus.uio.no/smr/english/about/id/docs/invest_int_concept_note_nov2019.pdf

(data zvernennia: 14.03.2021).

20. Barela S., Fallon M., Gaggioli G., Ohlin J. (Eds.), Interrogation and torture: Research on efficacy, and its integration with morality and legality. New York : Oxford University Press. 2020. $591 \mathrm{p}$.

21. Jakobsen K. K. Tolkning i forbindelse med politiafhøring. Problemer og mulige løsninger. Tolking i offentlig sektor. Vol. 2, No. 1. 2015. P. 1-14.

\title{
Kubariev Ivan,
}

$\mathrm{PhD}$ in Law, Associate Professor

(Donetsk State University of Internal Affairs, Kryvyi Rih)

ORCID: https://orcid.org/0000-0003-1053-9758

\author{
Barhan Serhii, \\ Master's Student \\ (Donetsk State University of Internal Affairs, Kryvyi Rih) \\ ORCID: https://orcid.org/0000-0002-1706-0355
}

\section{INTERROGATION TACTICS: FOREIGN EXPERIENCE}

The purpose of the study is to acquaint domestic experts with the theoretical developments of foreign criminologists on the tactics of interrogation in the pre-trial investigation and determine the trends of their development. Modern trends in law must qualitative rethinking of existing methods of interrogation in the direction of humanization. New methods of interrogation, which have been developed in foreign countries, propose to ensure the observance of human rights with the fulfillment of the tasks of criminal proceedings. The study of models such as PEACE and KREATIV shows the possibility of moving from interrogation to procedural interview. A procedural interview is an effective mechanism for collecting and recording accurate, reliable and reliable information during the investigation of criminal offenses. At the same time, modern models of interrogation do not resort to torture and other violations of human rights. Modern approaches to developing interrogation models focus on psychological and cognitive components. They contribute to the preparation of complete and truthful testimony of the interrogated. Thus, the article has described the foreign experience of interrogation as an effective mechanism for obtaining complete and reliable factual data in the pre-trial investigation. Based on the analysis of foreign models, the leading role of the humanistic and narrative approaches have determined in the development of new and improvement of existing methods of interrogation, which will ensure the proper implementation of the tasks of criminal justice. Modern approaches to the development of interrogatory models are concentrated on its psychological and cognitive components, within which the creation and maintenance of the proper level of communication, which will contribute to the completeness and objectivity of indications of interrogated, omitting indictment, coercive or obsessive approaches. According to the results of the research, an attempt we have made to single out the forensic features of interrogation models used in foreign countries to increase the effectiveness of the process of detection and investigation of criminal offenses.

Key words: interrogation; procedural interview; model PEACE; model KREATIV; tactic; criminalistics.

Надіслано до редколегії 06.05.2021

Рекомендовано до публікації 13.05.2021 
УДК: 343.132.1

DOI: https://doi.org/10.32366/2523-4269-2021-75-2-161-168

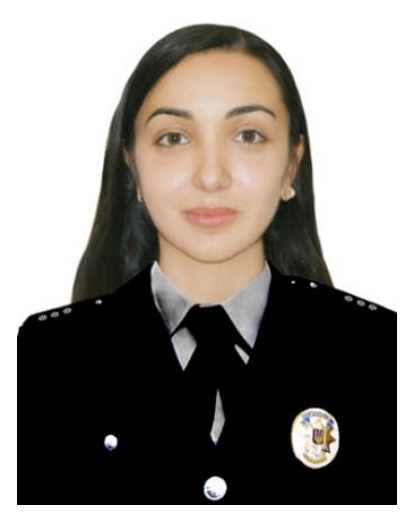

Курнасва Катерина Генійовна, ад'юнкт

(Донеиький державний університет внутрішніх справ, м. Маріуполь)

ORCID: https://orcid.org/0000-0002-4291-0497

\section{СЛІДЧИЙ ЕКСПЕРИМЕНТ У КРИМІНАЛЬНОМУ ПРОВАДЖЕННІ: ІСТОРИЧНИЙ АНАЛІЗ}

Аналізується історія формування слідчого експерименту як самостійної слідчої (розшукової) дії, історичні етапи виникнення, розвитку та визначення його місия в системі процесуальних дій у кримінальному провадженні України. Зазначається, що слідчий експеримент бере свій початок з практичної діяльності, а вже потім стає об'єктом дослідження криміналістичної та прочесуальної науки. Встановлено, щчо чіткої історичної періодизації розглянутого процесуального інституту не існує. Обгрунтовано висновок, щуо в Украӥні, незважаючи на закріплення слідчого експерименту в прочесуальному законодавстві як самостійної слідчої (розшукової) дії, досі залишаються неоднозначно тлумачені питання щэодо його регламентачіï, які потребують подальшого дослідження.

Ключові слова:

слідчий експеримент; відтворення обстановки та обставин подіі; слідча (розшукова) дія; тактичний метод; історичний аналіз; генеза.

Постановка проблеми. Кримінальний процесуальний кодекс України (далі - КПК України) 2012 р. змінив найменування слідчої (розшукової) дії, яка за КПК України 1960 р. називалася «відтворення обстановки та обставин події». Законодавець України застосував поняття «слідчий експеримент», традиційно використовуване в Російській Федерації та інших країнах пострадянського простору. При цьому було дещо змінено тлумачення сутності даної слідчої (розшукової) дії, що обумовлює необхідність дослідження цього питання, зокрема історичного аналізу появи слідчого експерименту в кримінальному провадженні.

Аналіз останніх досліджень і публікацій. Потрібно зазначити, що питанням генези слідчого експерименту протягом багатьох років приділялася певна увага, їх вивчали в різний час вітчизняні й зарубіжні вчені, такі як: Л. Е. Ароцкер, Т. М. Балицький, Р. С. Бєлкін, А. С. Рубан, М. С. Строгович, П. І. Тарасов-Родіонов та інші. Більшість цих досліджень була зосереджена на визначенні поняття слідчого експерименту, його правової природи та процесуальної регламентації. Однак кількість праць, у яких висвітлюється історичний аналіз становлення слідчого експерименту як самостійної слідчої дії, досить невелика. 3 цим, як убачається, пов'язана певна проблема, що стосується деяких процесуальних і тактичних аспектів слідчого експерименту після його регламентації в КПК України 2012 р. На сьогодні не існує його однозначного наукового тлумачення, що обумовлює необхідність історичного аналізу появи та статусу цієї слідчої дії в кримінальному провадженні.

Метою статті $\epsilon$ здійснення аналізу історичного розвитку уявлень про можливість

(C) Курнаєва Катерина Генійовна, 2021 
використання в кримінальному провадженні експериментального методу як способу отримання доказів та формулювання певних висновків, які дозволять більш ефективно використовувати його під час досудового розслідування.

Виклад основного матеріалу. Перше зародження ідеї слідчого експерименту, на думку деяких авторів, почалося ще в часи середньовіччя. Так, наприклад, в Англії після нормандського завоювання 1066 року XI ст. дуже поширеними були ордалії, або так званий «Божий суд», сутність якого полягала в процедурі пошуку істини в судовому спорі шляхом втручання надприродних сил. Як свідчать дані історичних джерел, ця процедура передбачала, що особа повинна була пройти певні випробування, у хід яких втручалося божество та видимим чином позначало винуватого та невинного. Наприклад, історик А. Ю. Золотарев у своїй праці «Ордалії в англо-нормандський час» згадує про випробування водою, окропом, залізом та вогнем. Так, сутність випробування окропом полягала в тому, що руку підсудного занурювали на глибину кулака або ліктя (проста або трійна ордалія; залежно від тяжкості злочину, який скоїв підсудний) у котел з окропом для того, щоб підсудний дістав камінь, який знаходився на дні [1, с. 314-318]. Таким чином, якщо через декілька днів на руці підсудного не було лущення або пухиря, то вважалося, що надприродні сили врятували невинного.

Згадки про перші ордалії та випробування в Україні походять із часів Київської держави XI-XII століття. У статті 85 Великої редакції «Руської правди» вина визначалася шляхом «Божого суду», а саме через випробування залізом [2, с. 9-25]. Так, випробування залізом - це спосіб очищення від вини в разі підозри в крадіжці чи вбивстві. Воно полягало в тому, що підозрюваний мусив тримати в руках розпечене залізо. Якщо опіків не було, то він визнавався невинним. У цьому випадку підозрюваний сплачував плату князеві [3, с. 200].

Поштовхом для початку розвитку слідчого експерименту як самостійної слідчої дії стає затвердження комплексної реформи судоустрою та судочинства в Російській імперії 1864 року, суть якої полягала в тому, що до кримінального процесу додали судове слідство, яке відокремили від попереднього (поліцейського) слідства та поліцейського дізнання, та, у свою чергу, відійшли від теорії формальних доказів. Отже, слідство набуло поглибленого інтересу до збору інформації, отримання та оцінювання незалежних доказів у справі. Основоположним документом реформи став Статут кримінального судочинства Російської імперії, прийнятий у 1864 році. До цієї події докази в суді оцінювалися за балами (суддя мав набрати 25 балів, до цього часу він не міг винести вирок. Визнання провини обвинуваченим оцінювалося в 25 балів, а показання селянина (свідка) - 2 бали). Формалізація доказів відбувалася в різних системах кримінального процесу. Такий підхід формував відповідні погляди на цінність тих чи інших джерел доказів [4, с. 16].

Починаючи з 30-х років XX ст., питання слідчого експерименту розглядають такі вчені, як П. П. Міхєєв і Н. Н. Семенов, роблячи акцент на тому, що перевірка показань може бути проведена спільно із зіставленням їх з іншими показаннями й обставинами справи, з оглядом, а також за допомогою дослідів і фактичних перевірок [5, с. 78]. Підсумковим стало положення, що під час проведення слідчого експерименту отримуються нові докази (як результат перевірки попередньо отриманих відомостей).

У 50-х роках минулого століття думки вчених стосовно змісту та юридичної природи слідчого експерименту розділилися. Відповідно до першої точки зору слідчий експеримент $\epsilon$ різновидом огляду. Так, Р. Д. Рахунов відзначав, що слідчий експеримент належить до комплексу заходів, що становлять зміст огляду місця події [6, с. 19-24]. М. С. Строгович також уважав, що слідчий експеримент за своєю юридичною природою є видом огляду в другій (динамічній) стадії, але при цьому зауважував про деякі його відмінності від стандартного огляду [7, с. 131]. П. І. Тарасов-Родіонов визначав слідчий експеримент як тактичний прийом розслідування та особливий вид огляду - «інсценування». На думку вказаного автора, метою слідчого експерименту є перевірка доказів та успішне з'ясування обставин злочину, а зміст вищезазначеної слідчої дії становить «штучне відтворення слідчим або судом тих чи інших обставин злочину, події або окремих його елементів, організовується для перевірки доказів $\mathrm{i}$ найкращого з'ясування окремих обставин справи» [8, с. 80; 9, с. 509]. 
Узагальнюючи наведені вище положення, можна резюмувати, що їх автори розглядали слідчий експеримент як тактичний прийом (а не самостійну слідчу дію), який використовується під час проведення інших слідчих дій, або як невід'ємну частину слідчої дії.

Іншу точку зору щодо сутності слідчого експерименту висловили та обгрунтували Є. Л. Ароцкер [10], І. Н. Гуковська [11], Р. С. Бєлкін [12] та інші, які вважали, що слідчий експеримент - це окрема самостійна слідча дія, що виходить далеко за межі інших слідчих дій, відмінною рисою якої є дослідна перевірка. Є. Л. Ароцкер у 1951 році захистив дисертацію на тему «Слідчий експеримент в радянській криміналістиці», де одним із перших надав поняття слідчого експерименту, проаналізував його значення для практики, визначив види, тактику підготовки та проведення, здійснив оцінку отриманих результатів $[10$, с. 6]. Він розглядав слідчий експеримент як «слідчу дію слідчого або суду, що полягає в проведенні випробувань у спеціально створених для цього умовах 3 метою перевірки версій слідчого, пояснень обвинуваченого, показань свідка для встановлення існування певних фактів у справі» [10, c. 15]. Також була опублікована низка праць радянських науковців, зокрема В. П. Колмакова, Ф.К. Діденка та інших, у яких визначалася самостійна юридична природа слідчого експерименту та його процесуальна сутність [13; 14].

Перше офіційне закріплення поняття «слідчий експеримент» відбулося в Юридичному словнику 1953 року, де зазначалося, що слідчий експеримент - це слідча дія, яка проводиться слідчим з метою відтворення окремих обставин або окремих фактів розслідуваного злочину. Але в цьому тлумаченні була відсутня вказівка на експериментальні та наукові досліди, які притаманні експерименту [15]. Згодом П. І. Тарасов-Родіонов опублікував монографію «Попереднє слідство» (1955р.), у якій вже посилався на те, що слідчий експеримент - це не тактичний прийом (як він уважав раніше), а особливий вид огляду, під час здійснення якого дослідження явищ, фактів та подій відбувається шляхом проведення дослідів. У цій роботі він висвітлив багато проблемних питань стосовно проведення досудового слідства, підстав, тактики та процесуального порядку проведення слідчих дій, у тому числі слідчого експерименту [16]. Напередодні прийняття нового КПК Російської Соціалістичної Федеративної Радянської Республіки (далі - РСФРР) у 1959 році Р. С. Бєлкін опублікував монографію «Теорія та практика слідчого експерименту», в якій надавалися пропозиції щодо включення слідчого експерименту до кримінально-процесуального законодавства як особливого засобу доказування [17]. На той час достовірним доказом вини підозрюваного в кримінально-процесуальній науці вважалося «визнання провини». Саме «визнання провини» зародилося завдяки переоцінці слідчих заходів, спрямованих на спростування чи підтвердження показань підозрюваного. Разом з цим закладається перевірка й уточнення доказів за допомогою слідчого експерименту.

Потрібно зазначити, що до кінця 50-х років учені та науковці так і не зуміли дійти до спільної думки щодо ролі слідчого експерименту в системі процесуальних дій: не було єдиного розуміння правової сутності слідчого експерименту. Незважаючи на це, у новий КПК РСФРР від 27.10.1960 року на законодавчому рівні була включена ст. 183, у якій визначалася можливість проведення нової самостійної слідчої дії - слідчого експерименту, а також встановлювалися правові основи іiі проведення [18]. Ця подія сприяла подальшому вдосконаленню процесуальних і тактичних аспектів проведення слідчого експерименту й більш глибокому вивченню його сутності та правової регламентації. Потрібно звернути увагу, що в КПК РСФРР містилася вказівка на дві схожі слідчі дії - «слідчий експеримент» і «перевірка показань та обставин на місці». Однак не було надано визначення на законодавчому рівні їх сутності та відмінностей.

Доцільно зауважити, що ідею формулювання такої слідчої дії, основу якої складало б використання експериментального методу пізнання, у КПК Української Радянської Соціалістичної Республіки (далі - УРСР) від 28.12.1960 року було позначено як «відтворення обстановки та обставин події» (ст. 194). Установлювалося, що з метою перевірки й уточнення результатів допиту свідка, потерпілого, підозрюваного або обвинуваченого чи даних, отриманих під час проведення огляду та інших слідчих дій, слідчий може виїхати на місце 
події і в присутності понятих, а в разі необхідності - за участю спеціаліста, свідка, потерпілого і підозрюваного або обвинуваченого відтворити обстановку та умови, в яких ті чи інші події могли відбуватися в дійсності [19]. У такий спосіб український законодавець в одній слідчій дії фактично об’єднав і «слідчий експеримент», i «перевірку показань та обставин на місці».

Також потрібно підкреслити, що праці радянських криміналістів-процесуалістів значно вплинули на розвиток інституту слідчого експерименту i в зарубіжних країнах. Так, наприклад, роботи Р. С. Бєлкіна видавалися англійською, польською, болгарською, чеською та німецькою мовами [20, с. 8-14]. Одночасно з розвитком інституту слідчого експерименту в кримінально-процесуальному законодавстві РСФРР та інших радянських республік починається розвиток цієї слідчої дії і в європейських державах.

Після проголошення незалежності України, 24 серпня 1991 року, на території всієї країни залишився дійсним раніше чинний Кримінально-процесуальний кодекс УРСР від 28.12.1960 [19], який окремої статті про слідчий експеримент не містив. Однак 13 квітня 2012 року було прийнято новий Кримінально-процесуальний кодекс України, в якому слідчий експеримент був визначений слідчою дією (ст. 240). Указувалося, що це самостійна слідча (розшукова) дія, що проводиться 3 метою перевірки й уточнення відомостей, які мають значення для встановлення обставин кримінального правопорушення. Слідчий, прокурор наділялися правом проведення слідчого експерименту шляхом відтворення дій, обстановки, обставин певної події, проведення необхідних дослідів чи випробувань [21].

Порівнюючи зміст ст. 194 КПК УРСР від 28.12.1960 року «Відтворення обстановки та обставин події» зі ст. 240 КПК України від 13.04.2012 року «Слідчий експеримент», переконуємося, що частково зміст ст. 240 КПК України було взято зі ст. 194 КПК УРСР. Головною метою в обох випадках визначалася перевірка й уточнення певних відомостей шляхом відтворення обстановки певної події. Тому поняття «відтворення» $є$ домінуючим елементом змісту обох статей. Водночас у ст. 240 КПК України 2012 р. законодавець додав, що, крім відтворення, слідчий експеримент може бути проведено шляхом «необхідних дослідів чи випробувань».

У зв’язку з цим потрібно зазначити, що поняття експерименту тлумачиться як один 3 основних методів наукового дослідження, в якому вивчення явищ відбувається за допомогою доцільно вибраних або штучно створених умов [22]. Однак слідчий у своїй практичній діяльності не може проводити саме наукові дослідження, адже для цього потрібні знання зі спеціальної галузі. Отже, він лише проводить дослідні дії, які грунтуються на його навичках та досвіді, хоча може залучати для допомоги і спеціалістів. Тому слідчий саме шляхом відтворення проводить перевірку й уточнення відомостей для встановлення обставин кримінального правопорушення. Адже відтворення грунтується на перевірці, виявленні чи встановленні певних відомостей дослідним шляхом.

На підставі наведеного вище потрібно зауважити, що окремими авторами запропонована певна періодизація становлення слідчого експерименту як самостійної слідчої (розшукової) дії, що знайшло відображення в кримінальному процесуальному законодавстві України. Так, Т. М. Балицький виділив чотири основні історичні етапи становлення слідчого експерименту:

1) середина XIX століття - кінець $30-\mathrm{x}$ років XX століття (у цей період почалося формування поняття експерименту, визначалася його правова природа, методи та способи реалізації, функції, цілі та завдання);

2) 40-50-ті роки ХХ ст. (відбувалося відокремлення експериментального методу від змісту інших слідчих дій);

3) 1960-2012 роки (відбулося законодавче закріплення слідчого експерименту як самостійної слідчої дії та вдосконалення його процесуальної регламентації і понятійного апарату);

4) 313 квітня 2012 р. (дата прийняття нового КПК України) і дотепер [23, с. 103$104]$. 
У зв'язку з наведеною періодизацією Т. М. Балицького зазначимо, що в цілому вона $є$ обгрунтованою. Проте варто звернути увагу, що з отриманням суверенітету Україною i реформуванням іiі кримінального процесуального законодавства, його наближенням до демократичних стандартів, четвертий етап не $\epsilon$ закінченим: низка положень і рекомендацій щодо підготовки та проведення слідчого експерименту, попередньо сформульованих у наукових працях і навчальних посібниках, потребує ретельного аналізу та вдосконалення.

Висновок. Підсумовуючи викладене щодо генези слідчого експерименту, потрібно зробити висновок, що названа слідча дія пройшла складний і суперечливий шлях свого розвитку, сформувавшись на основі багаторічного практичного досвіду. Саме як метод практичної діяльності щодо дослідження (перевірки) доказів експеримент став об'єктом вивчення наук кримінального процесу та криміналістики, тільки після цього він отримав нормативне закріплення у статусі окремої слідчої (розшукової) дії. Спочатку це була одна 3 найбільш трудомістких за своєю структурою і змістом дій, яка потребувала чіткого засвоєння iї сутності та завдань у процедурі збирання доказів з урахуванням ситуацій, які виникають під час кримінального провадження. Тому визначення окремих форм використання слідчого експерименту під час досудового розслідування, їх процесуальної регламентації в сучасних умовах, а отже і формулювання практичних рекомендацій щодо прийняття рішення про його проведення, підготовку й реалізацію потребують подальшого наукового аналізу. Саме це, на нашу думку, і $є$ завданням четвертого етапу в генезі слідчого експерименту.

\section{Список використаних джерел}

1. Золотарев А. Ю. Ордалии в англо-нормандское время. Известия Саратовского университета. Новая серия. Серия «История. Международные отношения». 2018. Т. 18. Вып. 3. C. 314-318. DOI: 10.18500/1819-4907-2018-18-3-314-318.

2. Титов Ю. П. Русская Правда. Пространная редакция. Хрестоматия по истории государства и права России / под. ред. Ю. П. Титова, О. И. Чистякова. М., 2007. С. 9-25.

3. Гайдай Л. І. Історія України в особах, термінах, назвах і поняттях. Луцьк: Вежа, $2000.436 \mathrm{c}$.

4. Пилявец С. В. Современные проблемы проведения проверки показаний на месте: уголовно-процессуальные и криминалистические аспекты : дисс. ... канд. юрид. наук : 12.00 .09 «Уголовный процесс и криминалистика; судебная экспертиза». Калининград, 2004. $198 \mathrm{c.}$

5. Михеев П. П., Семенов Н. Н. Криминалистика. Уголовный и уголовнопроцессуальный кодексы: в вопросах и ответах : пособие для внешкольной подготовки сотрудников милиции и уголовного розыска. М. : Авторское издание, 1927. 112 с.

6. Рахунов Р. Д. Прямые и косвенные доказательства. Социалистическая законность. 1959. № 7. С. 19-24.

7. Строгович М. С. Курс советского уголовного процесса. М.: издательство «Наука», 1970. Том 2 : Порядок производства по уголовным делам по советскому уголовнопроцессуальному праву. $161 \mathrm{c.}$

8. Александров Г. Н., Апурин А. И., Арзуманян Т. М., Арсеньев Б. Я. и др. Настольная книга следователя / под общ. ред. Г. И. Сафонова; редкол.: С. Я. Розенблид, П. И. Тарасов-Родионов, Л. Р. Шейнин. М.: Горюриздат, 1949. 879 с.

9. Тарасов-Родионов П. И. Криминалистика. Техника и тактика расследования преступлений. М.: Юрид. изд-во НКЮ СССР, 1938. 509 с.

10. Ароцкер Л. Е. Следственный эксперимент в советской криминалистике : автореф. дисс. ... канд. юрид. наук : 12.00.09. Х., 1951. 35 с.

11. Гуковская Н. И. Следственный эксперимент : пособие для следователей. М., 1957. $233 \mathrm{c}$.

12. Белкин Р. С. Эксперимент в следственной, судебной и экспертной практике. М., 1953. $330 \mathrm{c}$. 
13. Колмаков В. П. Тактика производства следственного осмотра и следственного эксперимента. Х., 1956. 48 с.

14. Диденко Ф. К. Следственный эксперимент в практике органов военной юстиции. М., 1957. 32 с.

15. Государственное издательство юридической литературы / С. Н. Братусь, Н. Д. Казанцев, С. Ф. Кечекьян, Ф. И. Кожевников, В. Ф. Коток, П. И. Кудрявцев, В. М. Чхиквадзе. М., 1953. 784 с.

16. Тарасов-Родионов П. И. Предварительное следствие / под ред.: Г. Н. Александрова, С. Я. Розенблита. М. : Госюриздат, 1955. 247 с.

17. Белкин Р. С. Теория и практика следственного эксперимента / под общ. ред. А. И. Винберга. М.: ВШ МВД СССР, 1959. 171 с.

18. Уголовно-процессуальный кодекс РСФСР от 27.10.1960. URL: http://www.kremlin.ru/acts/bank/1/page/10 (дата звернення: 20.01.2021).

19. Кримінально-процесуальний кодекс УРCP від 28.12.1960. URL: http://zakon2.rada.gov.ua/laws/show/1002-05/page4 (дата звернення: 20.01.2021).

20. Россинская Е. Р. К 95-летию профессора Р. С. Белкина. Краткий биографический очерк. Теория и практика судебной экспертизы. 2017. Том 12. № 3. С. 8-14.

21. Кримінальний процесуальний кодекс України : Закон України від 13.04.2012 № 4651-VI. Верховна Рада України. URL: https://zakon.rada.gov.ua/laws/show/4651-17 (дата звернення: 20.01.2021).

22. Новий тлумачний словник української мови. Київ : вид-во «Аконіт», 2006. Т. 1 : A-K. 926 c.

23. Балицький Т. М. Виникнення та розвиток ідеї слідчого експерименту. Науковий вісник Міжнародного гуманітарного університету. Серія: Юриспруденція. 2013. Випуск 6-3. Том 2. C. 103-104.

\section{References}

1. Zolotarev, A. YU. (2018). Ordalii v anglo-normandskoe vremya. Izvestiya Saratovskogo universiteta. Novaya seriya. Ser. «Istoriya. Mezhdunarodnye otnosheniya» [Ordals in English-Norman Time]. T. 8. Vyp. 3. S. 314-318. DOI: 10.18500/1819-4907-2018-18-3-314-318 [in Russian].

2. Titov, YU. P. (2007). Russkaya Pravda. Prostrannaya redakciya. Hrestomatiya po istorii gosudarstva $i$ prava Rossii [Reader on the history of state and law of Russia]. M. S. 9-25 [in Russian].

3. Haidai, L. I. (2000). Istoriia Ukrainy v osobakh, terminakh, nazvakh i poniattiakh [History of Ukraine in persons, terms, names and concepts]. Lutsk: Vezha. 436 s. [in Ukrainian].

4. Pilyavec, S. V. (2004). Sovremennye problemy provedeniya proverki pokazanij na meste: ugolovno-processual'nye i kriminalisticheskie aspekty : diss. ... kand. yurid. nauk : 12.00.09 «Ugolovnyj process i kriminalistika; sudebnaya ekspertiza» [Current challenges in on-site verification of readings]. Kaliningrad. 198 s. [in Russian].

5. Miheev, P. P., Semenov, N. N. (1927). Kriminalistika. Ugolovnyj i ugolovnoprocessual'nyj kodeksy: v voprosah i otvetah : posobie dlya vneshkol'noj podgotovki sotrudnikov milicii i ugolovnogo rozyska [Forensic science. Criminal and criminal procedure codes: in questions and answers]. M. : Avtorskoe izdanie. 112 s. [in Russian].

6. Rahunov, R. D. (1959). Pryamye i kosvennye dokazatel'stva [Direct and indirect evidence]. Socialisticheskaya zakonnost'. № 7. S. 19-24 [in Russian].

7. Strogovich, M. S. (1970). Kurs sovetskogo ugolovnogo processa [Soviet Criminal Procedure Course]. M. : izdatel'stvo «Nauka». Tom 2 : Poryadok proizvodstva po ugolovnim delam po sovetskomu ugolovno-processual'nomu pravu. 161 s. [in Russian]. 
8. Aleksandrov, G. N., Apurin, A. I., Arzumanyan, T. M., Arsen'ev, B. YA. i dr. (1949). Nastol'naya kniga sledovatelya [Investigator's Handbook] / pod obshch. red. G. I. Safonova; redkol.: S. YA. Rozenblid, P. I. Tarasov-Rodionov, L. R. SHejnin. M.: Goryurizdat. 879 s. [in Russian].

9. Tarasov-Rodionov, P. I. (1938). Kriminalistika. Tekhnika i taktika rassledovaniya prestuplenij [Forensics: Technique and tactics of crime investigation]. M. : YUrid. izd-vo NKYU SSSR. 509 s. [in Russian].

10. Arocker, L. E. (1951). Sledstvennyj eksperiment v sovetskoj kriminalistike : avtoref. diss. ... kand. yurid. nauk : 12.00 .09 [Investigative experiment in Soviet forensics]. H. $35 \mathrm{~s}$. [in Russian].

11. Gukovskaya, N. I. (1957). Sledstvennyj eksperiment : posobie dlya sledovatelej [Investigative experiment: a guide for investigators]. M. 233 s. [in Russian].

12. Belkin, R. S. (1953). Eksperiment v sledstvennoj, sudebnoj i ekspertnoj praktike [Experiment in investigative, forensic and expert practice]. M., $330 \mathrm{~s}$. [in Russian].

13. Kolmakov, V. P. (1956). Taktika proizvodstva sledstvennogo osmotra i sledstvennogo eksperimenta [Tactics of production of investigative examination and investigative experiment]. Har'kov. 48 s. [in Russian].

14. Didenko, F. K. (1957). Sledstvennij eksperiment v praktike organov voennoj yusticii [Investigative experiment in the practice of military justice bodies]. Moskva. $32 \mathrm{~s}$. [in Russian].

15. Gosudarstvennoe izdatel'stvo yuridicheskoj literatury [State publishing house of legal literature] / S. N. Bratus', N. D. Kazancev, S. F Kechek'yan, F. I. Kozhevnikov, V. F Kotok, P. I. Kudryavcev, V. M. CHkhikvadze. M., 1953. 784 s. [in Russian].

16. Tarasov-Rodionov, P. I. (1955). Predvaritel'noe sledstvie [Preliminary investigation] / pod red.: G. N. Aleksandrova, S. YA. Rozenblita. M. : Gosyurizdat. 247 s. [in Russian].

17. Belkin, R. S. (1959). Teoriya i praktika sledstvennogo eksperimenta [Theory and practice of the investigative experiment] / pod obshch. red. A I. Vinberga. M.: VSH MVD SSSR. 171 s. [in Russian].

18. Ugolovno-processual'nyj kodeks RSFSR ot 27.10.1960 [Criminal Procedure Code of the RSFSR]. URL: http://www.kremlin.ru/acts/bank/1/page/10 (data zvernennia: 20.01.2021) [in Russian].

19. Kryminalno-protsesualnyi kodeks URSR vid 28.12.1960 [Criminal Procedure Code of the USSR]. URL: http://zakon2.rada.gov.ua/laws/show/1002-05/page4 (data zvernennia: 20.01.2021) [in Ukrainian].

20. Rossinskaya, E. R. (2017). K 95-letiyu professora R. S. Belkina. Kratkij biograficheskij ocherk [To the 95th anniversary of Professor R. S. Belkin. Brief biographical sketch]. Teoriya i praktika sudebnoj ekspertizy. Tom 12. № 3. S. 8-14 [in Russian].

21. Kryminalnyi protsesualnyi kodeks Ukrainy : Zakon vid 13.04.2012 № 4651-VI. Verkhovna Rada Ukrainy [Criminal Procedure Code of Ukraine]. URL: https://zakon.rada.gov.ua/laws/show/4651-17 (data zvernennia: 25.01.2021) [in Ukrainian].

22. Novyi tlumachnyi slovnyk ukrainskoi movy [New explanatory dictionary of the Ukrainian language]. Kyiv: vyd-vo «Akonit», 2006. T. 1 : A-K. 926 s. [in Ukrainian].

23. Balytskyi, T. M. (2013). Vynyknennia ta rozvytok idei slidchoho eksperymentu [The emergence and development of the idea of an investigative experiment]. Naukovyi visnyk Mizhnarodnoho humanitarnoho universytetu. Seriia: Yurysprudentsiia. Vypusk 6-3. Tom 2. S. 103104 [in Ukrainian]. 


\section{Kurnaieva Kateryna,}

Postgraduate

(Donetsk State University of Internal Affairs, Mariupol)

ORCID: https://orcid.org/0000-0002-4291-0497

\section{INVESTIGATIVE EXPERIMENT IN CRIMINAL PROCEEDINGS: HISTORICAL ANALYSIS}

The article is devoted to the genesis of the investigative experiment as an independent investigative (search) action. The author analyzes the historical stages of origin, development, and determination of the place of the investigative experiment in the system of procedural actions in Ukraine. It is noted that the investigative experiment as a way to verify the evidence arose in the practice of pre-trial investigation. And then it became the object of study of legal science research. It is noted that the basis of the investigative experiment is the use of the method of scientific research method-testing to verify certain information. This is a sign of the introduction of truly scientific methods in the activities of law enforcement agencies. In this way the obtained evidence is given signs of belonging and admissibility. The testimony of the participants in the criminal proceedings and the investigative versions are checked by conducting an investigative experiment. Thus the reliability of the received information and the maintenance of a criminal offense is established. That is why the investigative experiment became widespread in the pre-trial investigation. Investigative experiment is a way to verify and to obtain evidence, but one of the most complex in its preparation and content. It is established that there is no detailed clear historical periodization of this procedural institution. The article compares the content of art. 194 of the Criminal Procedure Code of the Ukrainian Soviet Socialist Republic dated 28.12.1960 «Reproduction of the situation and circumstances of the event» from art. 240 of the Criminal Procedure Code of Ukraine dated 13.04.2012 "Investigative experiment». The conclusion that the investigative experiment is an independent investigative (investigative) action is substantiated, but some questions concerning its conduct remain ambiguous. Currently, this is the basis for discussions, which indicates the relevance of this procedural institution and its development.

Key words: investigative experiment; reproduction of the situation and circumstances of the event; investigative (search) action; tactical method; historical analysis; genesis.

Надіслано до редколегії 26.02.2021

Рекомендовано до публікації 05.03.2021 
УДК: 343.13

DOI: https://doi.org/10.32366/2523-4269-2021-75-2-169-174

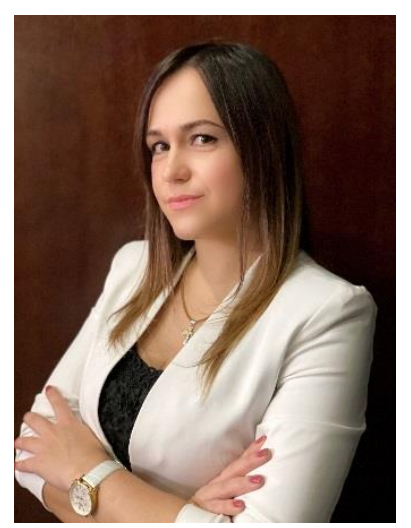

\author{
Савчук Марина Анатоліївна, \\ викладач \\ (Донецький державний університет \\ внутрішніх справ, м. Кривий Ріг) \\ ORCID: https://orcid.org/0000-0002-3467-4690
}

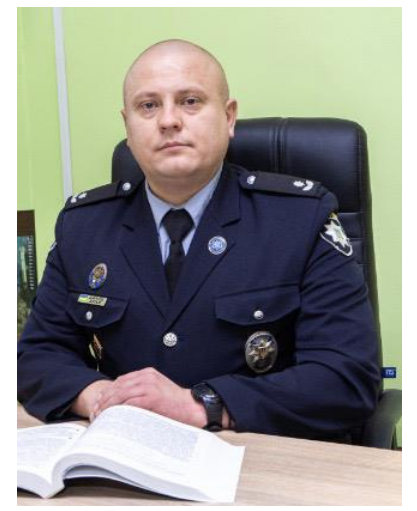

Шапарь Артем Олександрович, кандидат юридичних наук (Донеиький державний університет внутрішніх справ, м. Кривий Ріг)

ORCID: https://orcid.org/0000-0001-5327-701X

\title{
ОБГРУНТОВАНІСТЬ ПІДОЗРИ ЯК УМОВА ЗАСТОСУВАННЯ ЗАХОДІВ ЗАБЕЗПЕЧЕННЯ КРИМІНАЛЬНОГО ПРОВАДЖЕННЯ
}

Наукова стаття містить відомості щзодо визначення сутності поняття «обгрунтованість підозри», дослідження слідчим суддею доказів, які обтрунтовують підозру під час застосування заходів забезпечення кримінального провадження. Проаналізовано основні ознаки обтрунтованості підозри як стандарту доказування $у$ кримінальному провадженні. Розглянуто наукові прачі із зазначеної тематики, рішення Свропейського суду з прав людини та норми національного законодавства. Зроблено висновок, щуо повідомлення особи про підозру жодним чином не може обтрунтовувати застосування заходів забезпечення кримінального провадження.

Ключові слова: повідомлення про підозру; обтрунтованість підозри; заходи забезпечення кримінального провадження; досудове розслідування; рішення суду.

Постановка проблеми. Важливу роль у вирішенні завдань кримінального процесу відіграє інститут заходів забезпечення кримінального провадження. Ураховуючи, що такі заходи обмежують права підозрюваного (обвинуваченого), законодавець визначив відповідну правову регламентацію, зокрема застосування для низки з них «обгрунтованості підозри». Водночас аналіз практики свідчить, що суди не приділяють достатньої уваги цій умові, не завжди наводять доводи щодо обгрунтування підозри під час застосування заходів забезпечення кримінального провадження. Причинами цього є незначна кількість наукових

(C) Савчук Марина Анатоліївна,

Шапарь Артем Олександрович, 2021 
розробок категорії обгрунтованості підозри та недостатність їі закріплення у кримінальнопроцесуальному законодавстві.

Аналіз останніх досліджень та публікацій. Питання застосування заходів забезпечення кримінального провадження та обгрунтованості підозри розглядалися у працях таких українських учених, як Н. В. Глинська, І. В. Гловюк, М. С. Громова, Л. М. Лобойко, Т. В. Лукашкіна, М. А. Макаров, О. І. Марочкін, Ю. Д. Москалюк, А. І. Палюх, В. В. Рожнова, А. Е. Руденко, Д. О. Савицький, С. М. Смоков, О. Ю. Татаров, О. І. Тищенко, А. Р. Туманянц, Л. Д. Удалова, О. Ю. Хабло, А. Я. Хитра, С. Л. Шаренко, О. Г. Шило та ін. У роботах цих авторів висвітлено питання правової природи заходів забезпечення та особливості нормативної регламентації, порядок застосування, а також проблемні питання розгляду слідчим суддею та судом відповідних клопотань. Проте ще залишаються окремі аспекти, які потребують дослідження.

Метою статті $\epsilon$ визначення ролі обгрунтованості підозри у прийнятті рішення під час застосування заходів забезпечення кримінального провадження.

Виклад основного матеріалу. Дослідження поняття «обгрунтованість підозри» відбувається 3 урахуванням того, що цей термін пов'язаний 3 такими категоріями у кримінально-процесуальному законодавстві: доказами як підставою для визнання підозри обгрунтованою або ні; юридичними властивостями доказів (належність, допустимість, достовірність, достатність); підозрюваним як учасником кримінального провадження, якому на підставі зібраних доказів повідомлено про підозру; заходами забезпечення кримінального провадження шляхом застосування до підозрюваного певних обмежувальних заходів під час розслідування.

У будь-якому разі такий тісний взаємозв'язок з іншими кримінально-процесуальними категоріями лише підтверджує актуальність цієї теми та необхідність ії дослідження.

У положеннях ст. 131 Кримінально-процесуального кодексу України (далі КПК України) є чіткий перелік заходів забезпечення кримінального провадження: 1) виклик слідчим, дізнавачем, прокурором, судовий виклик і привід; 2) накладення грошового стягнення; 3) тимчасове обмеження у користуванні спеціальним правом; 4) відсторонення від посади; $4^{1}$ ) тимчасове відсторонення судді від здійснення правосуддя; 5) тимчасовий доступ до речей і документів; 6) тимчасове вилучення майна; 7) арешт майна; 8) затримання особи; 9) запобіжні заходи [1].

У частині 3 ст. 132 КПК України зазначено, що застосування заходів забезпечення кримінального провадження не допускається, якщо слідчий, дізнавач, прокурор не доведе, що: 1) існує обгрунтована підозра щодо вчинення кримінального правопорушення такого ступеня тяжкості, що може бути підставою для застосування заходів забезпечення кримінального провадження; 2) потреби досудового розслідування виправдовують такий ступінь втручання у права і свободи особи, про який ідеться в клопотанні слідчого, дізнавача, прокурора; 3) може бути виконане завдання, для виконання якого слідчий, дізнавач, прокурор звертається 3 клопотанням.

Однією $з$ підстав правомірного застосування заходів забезпечення кримінального провадження $є$ наявність обгрунтованої підозри. Указана норма свідчить, що жоден із заходів забезпечення кримінального провадження не може бути вжитий без доведення обгрунтованості підозри щодо вчинення кримінального правопорушення. Оцінка критерію «обгрунтована підозра» здійснюється судом, а під час розгляду клопотань про застосування заходів забезпечення кримінального провадження - слідчим суддею.

У законодавстві України відсутнє чітке тлумачення поняття «обгрунтованість підозри», тому виникають правові неточності у вирішенні процесуальних питань. Деякі науковці пропонують надати визначення цього терміна та нормативно його закріпити.

Як зазначає М. Є. Громова, обгрунтованою слід вважати підозру за наявності таких принципових обставин: вручення письмового повідомлення про підозру 3 обов'язковим посиланням на докази вчинення особою кримінального правопорушення; наявності у матеріалах кримінального провадження доказів, що підтверджують вчинення особою 
кримінального правопорушення; доведення перед судом вагомості та достатності наявних доказів про вчинення особою кримінального правопорушення; оцінювання судом доказів вчинення особою кримінального правопорушення [2].

О. З. Гладун, О. В. Зелінський уважають, що обгрунтованість підозри є обов'язковим предметом судового контролю під час розгляду клопотань щодо застосування запобіжного заходу, вирішення питання про арешт майна. До того ж суд не приймає рішення про скасування повідомлення про підозру, але може відмовити в задоволенні відповідних клопотань через те, що особа не набула статусу підозрюваного [3].

У разі вирішення питання про застосування заходу забезпечення кримінального провадження причетність особи до вчинення кримінального правопорушення не повинна мати категоричного висновку, а свідчити лише про їі можливість. Слідчий суддя в жодному разі не повинен установлювати причетність особи поза розумним сумнівом, тому що обгрунтована підозра має підтверджуватися конкретними фактами та обставинами, що можуть переконати об'єктивного спостерігача, тобто непрофесіонала у сфері права, у наявності зв'язку між діями особи та подією. Такі фактичні обставини повинні бути чіткими та зрозумілими i відображатися у відповідному рішенні компетентного органу [4].

Також обгрунтованість підозри у кримінальному провадженні варто застосовувати 3 урахуванням не тільки норм національного законодавства, а й практики Європейського суду 3 прав людини (далі - ССПЛ).

На підставі аналізу Єдиного державного реєстру судових рішень з'ясовано, що найчастіше в судових рішеннях поняття «обгрунтована підозра» не визначене в національному законодавстві. 3 огляду на положення ч. 5 ст. 9 КПК України доцільно розглянути позицію ЄСПЛ, яка відображена в пункті 175 рішення у справі «Нечипорук і Йонкало проти України» від 21 квітня 2011 року, відповідно до якої термін «обгрунтована підозра» означає, що існують факти або інформація, які можуть переконати об'єктивного спостерігача в тому, що особа, про яку йдеться, могла вчинити правопорушення, і згідно 3 якою вимога розумної підозри передбачає наявність доказів, які об'єктивно пов'язують підозрюваного з певним злочином, вони не повинні бути достатніми, щоб забезпечити засудження, але мають бути достатніми, щоб виправдати подальше розслідування або висунення звинувачення (рішення у справі «Мюррей проти Об’єднаного Королівства» від 28 жовтня 1994 року, «Фокс, Кемпбелл і Гартлі проти Сполученого Королівства» від 30 серпня 1990 року) [5].

У п. 80 рішення у справі № 33492/96 «Яблонський проти Польщі» від 21 грудня 2000 року зазначено, що подальше існування обгрунтованої підозри в учиненні затриманою особою злочину $\epsilon$ обов'язковою i неодмінною умовою (sine qua non) належності iі продовжуваного тримання під вартою. Але через певний час така підозра припиняє сама по собі бути виправданням для позбавлення особи свободи, тому судові органи повинні вмотивовувати свої рішення про продовження тримання ії під вартою іншими підставами.

Варто також звернути увагу на рішення у справах «Котій проти України» (п. 42), «Нечипорук і Йонкало проти України» (п. 175), «Iglar Mammadov v. Azerbaijan» (п. 88), «Erdagos v. Turkey» (п. 51), «Cebotari v. Moldova» (п. 4), де ЄСПЛ відповідно до своєї прецедентної практики вказує на те, що саме в Конвенції розуміють як обгрунтовану підозру, а також зазначає, що для обгрунтованої підозри необхідними $є$ факти або інформація, які б переконали неупередженого спостерігача в тому, що ця особа, імовірно, вчинила злочин.

Цікавим є рішення ЄСПЛ у справі «Серявін та інші проти України» від 10 лютого 2010 року, де в пункті 58 зазначено, що згідно з його усталеною практикою, яка відображає принцип належного здійснення правосуддя, у рішеннях судів та інших органів 3 вирішення спорів мають бути належним чином зазначені підстави, на яких ці рішення грунтуються. Призначення обгрунтованого рішення полягає в тому, щоб продемонструвати сторонам, що вони були почуті. Крім того, умотивоване рішення дає стороні можливість оскаржити його та здійснити перегляд у вищій інстанції. Лише за умови винесення обгрунтованого рішення можна забезпечити публічний контроль за здійсненням правосуддя. 
Попри все зазначене, слідчі судді під час розгляду вказаного критерію зауважують, що на стадії досудового розслідування слідчий суддя не має права вирішувати питання допустимості та належності доказів, тому фактично не здійснюють перевірку та оцінку доказів на підтвердження обгрунтованості підозри, перевіряючи саме наявність документа.

Згідно зі ст. 94 КПК України слідчий, прокурор, слідчий суддя, суд за своїм внутрішнім переконанням, яке грунтується на всебічному, повному й неупередженому дослідженні всіх обставин кримінального провадження, керуючись законом, оцінюють кожний доказ з точки зору належності, допустимості, достовірності, а сукупність зібраних доказів - 3 точки зору достатності та взаємозв'язку для прийняття відповідного процесуального рішення [1].

На нашу думку, саме зміст ст. 94 КПК України вимагає кожного разу здійснювати оцінку доказів, у тому числі щодо перевірки обгрунтованості підозри, оскільки наявність процесуального документа (повідомлення про підозру) не $\epsilon$ обов’язковою гарантією іiї фактичної обгрунтованості.

Дослідження доказів під час досудового розслідування $\epsilon$ важливим чинником дотримання прав та свобод учасників процесу, а також недопущення прорахунків зі сторони слідства та прокурора під час збирання доказів. Саме докази забезпечують достовірне знання фактичних обставин, які входять до предмета доказування у кримінальному провадженні. Зважаючи на це, законодавець у ч. 5 ст. 132 КПК України передбачив, що під час розгляду питання про застосування заходів забезпечення кримінального провадження сторони кримінального провадження повинні подати слідчому судді або суду докази обставин, на які вони посилаються [1]. Через це не можна недооцінювати вплив доказів на підтвердження обгрунтованості підозри як необхідну умову забезпечення законних рішень.

Для учасників процесу судове рішення повинно бути не лише зрозумілим, але й обов'язково обгрунтованим та вмотивованим, а також переконливим як у частині встановлення фактичних обставин на основі перевірених та належних і допустимих доказів, так і в їхній правовій оцінці. Ухвала суду - результат справедливого процесу, наслідок перевірки й оцінки доказів і конкретного застосування принципів та норм права.

Наголошуючи на вагомості дослідження слідчим суддею наявності обгрунтованої підозри, І. В. Гловюк, Ю. А. Жовтан, Д. К. Пономаренко визнають, що «перевірка слідчим суддею саме обгрунтованості підозри має стати бар'єром для необгрунтованого кримінального переслідування та засобом належної реалізації загальних завдань кримінального провадження» [6].

Формальне ставлення та недосягнення мети судового контролю може призвести до зниження рівня авторитету правосуддя. Однією з причин цього є ненадання до суду доказів, достатніх для висновку про обгрунтовану підозру. Крім того, ухвали повинні бути оріснтовані на єдиний підхід - справедливий для всіх сторін, а не конкретний результат щодо підтримки сторони обвинувачення.

За наслідками розгляду справи важливо не лише формально отримати ухвалу, а й досягти юридичної визначеності проблеми з метою захисту прав чи інтересів сторони, якщо їх порушено (на думку учасника процесу). Реалізація цісї мети неможлива без перевірки обгрунтованості підозри, оскільки встановлено, що обгрунтована підозра $є$ необхідною умовою забезпечення обгрунтованості судових рішень.

Водночас варто наголосити, що, на нашу думку, саме факт повідомлення особи про підозру жодним чином не може обгрунтовувати застосування заходів забезпечення кримінального провадження.

Висновки. Отже, можна констатувати, що наявність повідомлення про підозру не є тотожним поняттю «обгрунтованість підозри». Для обгрунтування підозри сторони кримінального провадження зобов'язані надати слідчому судді докази обставин, на які вони посилаються. У свою чергу, обов'язком слідчого судді та суду є перевірка цих доказів та надання їм оцінки. До того ж наявність підозри не є підставою для висновку про застосування запобіжного заходу. 
Уважаємо, що більш ретельному підходу слідчого, прокурора та слідчого судді до оцінки обгрунтованості підозри під час застосування заходів забезпечення кримінального провадження сприятиме закріплення критеріїв у кримінально-процесуальному законі.

\section{Список використаних джерел}

1. Кримінальний процесуальний кодекс України. Відомості Верховної ради. 2013. № 9-10, № 11-12, № 13. Ст. 88. URL: https://zakon.rada.gov.ua/laws/show/4651-17\#n5941 (дата звернення: 19.04.2021).

2. Громова М. С. Обгрунтована підозра як підстава застосування запобіжних заходів. Часопис Академії адвокатури Украӥни. 2015. № 2 (27). С. 40-43.

3. Гладун О., Зелінський О. Повідомлення про підозру: кримінальна процесуальна дихотомія. Вісник Національної академії прокуратури України. 2018. № 2 (54). С. 58-72.

4. Гловюк I. В., Степаненко А. С. Стандарт доказування «обгрунтована підозра» у кримінальному провадженні. Правова позиція. 2018. № 1 (20). С. 19.

5. Ухвала Київського апеляційного суду від 26.04.2021 року. URL: https://reyestr.court.gov.ua/Review/96680107 (дата звернення: 19.04.2021).

6. Гловюк I., Жовтан Ю., Пономаренко Д. Перевірка слідчим суддею обгрунтованості підозри як засіб протидії необгрунтованому кримінальному переслідуванні. URL: $\quad$ https://unba.org.ua/publications/print/5251-perevirka-slidchim-suddeyu-obuntovanostipidozri-yak-zasib-protidii-neobuntovanomu-kriminal-nomu-peresliduvannyu.html (дата звернення: 19.04.2021).

\section{References}

1. Kryminalnyi protsesualnyi kodeks Ukrainy. Vidomosti Verkhovnoi rady Ukrainy [Criminal Procedure Code of Ukraine. Information of the Verkhovna Rada]. 2013. № 9-10, № 1112, № 13. St. 88. URL: https://zakon.rada.gov.ua/laws/show/4651-17\#n5941 (data zvernennia: 19.04.2021) [in Ukrainian].

2. Hromova, M. Ye. (2015). Obgruntovana pidozra yak pidstava zastosuvannia zapobizhnykh zakhodiv. Chasopys Akademii advokatury Ukrainy [Substantiated suspicion as a basis for the use of precautionary measures. The magazine of the Academy of Advocacy of Ukraine]. № 2 (27). S. 40-43 [in Ukrainian].

3. Hladun, O., Zelinskyi, O. (2018). Povidomlennia pro pidozru: kryminalna protsesualna dykhotomiia. Visnyk Natsionalnoi akademii prokuratury Ukrainy [Notification of suspicion: criminal procedural dichotomy. Bulletin of the National Academy of Prosecutor's Office of Ukraine]. № 2 (54). S. 58-72 [in Ukrainian].

4. Hloviuk, I. V., Stepanenko, A. S. (2018). Standart dokazuvannia «obgruntovana pidozra» u kryminalnomu provadzhenni. Pravova pozytsiia [The standard of proof is «grounded suspicion» in criminal proceedings. Legal position]. № 1 (20). S. 19 [in Ukrainian].

5. Ukhvala Kyivskoho apeliatsiinoho sudu vid 26.04.2021 roku [Decree of the Kyiv Appeal Court of 26.04.2021]. URL: https://reyestr.court.gov.ua/Review/96680107 (data zvernennia: 19.04.2021) [in Ukrainian].

6. Hloviuk, I., Zhovtan, Yu., Ponomarenko, D. Perevirka slidchym suddeiu obgruntovanosti pidozry yak zasib protydii neobgruntovanomu kryminalnomu peresliduvanni [Checking the investigative judge of reasonableness of suspicion as a means of counteracting unfounded criminal prosecution]. URL: https://unba.org.ua/publications/print/5251-perevirkaslidchim-suddeyu-obuntovanosti-pidozri-yak-zasib-protidii-neobuntovanomu-kriminal-nomuperesliduvannyu.html (data zvernennia: 19.04.2021) [in Ukrainian]. 


\title{
Savchuk Maryna,
}

Lecturer

(Donetsk State University of Internal Affairs, Kryvyi Rih)

ORCID: https://orcid.org/0000-0002-3467-4690

\author{
Shapar Artem, \\ $\mathrm{PhD}$ in Law \\ (Donetsk State University of Internal Affairs, Kryvyi Rih) \\ ORCID: https://orcid.org/0000-0001-5327-701X
}

\section{JUSTIFICATION OF SUSPICION DURING THE APPLICATION OF CRIMINAL PROCEEDING MEASURES}

The scientific article contains information on the study of the concept of «reasonableness of suspicion», the study by the investigating judge of the evidence that substantiates the suspicion during the application of precautionary measures. The article analyzes scientific works on certain topics, decisions of the European Court of Human Rights and national legislation. The main problem is identified, which is related to the fact that the investigating judge in most cases, when considering a request for a measure of restraint, ignores the need to examine the evidence related to the examination of suspicion. The result of the above material is the fact that the notification of a person of suspicion can in no way justify the application of measures to ensure criminal proceedings. An important procedural step, which plays a crucial role in the pre-trial investigation stage, is the notification of a person of suspicion. Suspicion is presented to a person only on the basis of proper, admissible, sufficient and reliable evidence, it allows to suspect a person of committing a criminal offense. The pre-trial investigation body does not always establish all sufficient grounds for such a suspicion, so the question arises as to its validity. After the notification of suspicion, it is possible to apply one of the measures to ensure criminal proceedings, namely: a precautionary measure. The norms of the criminal procedure law oblige the court, when choosing a measure of restraint, to take into account the data underlying such a decision. The presence of a notice of suspicion is not an identical notion of the validity of the suspicion. In order to substantiate the suspicion, the parties to the criminal proceedings are obliged to provide the investigating judge with evidence of the circumstances to which they refer, which in turn entails the duty of the investigating judge, the court to verify and evaluate the evidence. The presence of risks does not justify the suspicion. The need to comply with the rule on the verification of «reasonableness of suspicion» is realized by establishing criteria that should be investigated and established by the investigating judge during the consideration of motions for the application of measures to ensure criminal proceedings.

Key words: notification of suspicion; validity of suspicion; measures to ensure criminal proceedings; pre-trial investigation; court decision.

Надіслано до редколегії 17.05.2021

Рекомендовано до публікації 24.05.2021 


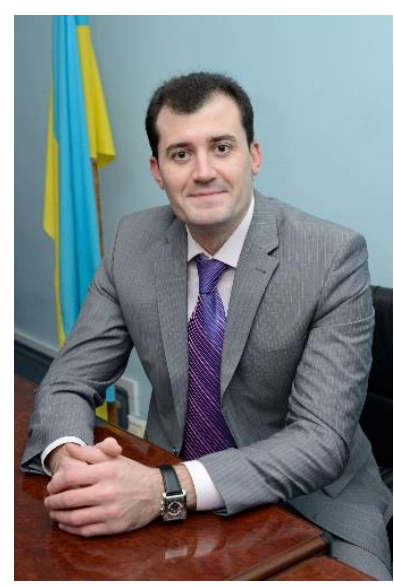

\section{Смирнов Максим Іванович,} кандидат юридичних наук, доцент

(Національний університет «Одеська юридична академія», M. Odeca)

ORCID: https://orcid.org/0000-0002-4563-5902

\section{ВІДЕОКОНФЕРЕНЦІЯ ЯК ПРОЦЕСУАЛЬНА ФОРМА ВИКОРИСТАННЯ ІНФОРМАЦІЙНИХ ТЕХНОЛОГІЙ У КРИМІНАЛЬНОМУ ПРОВАДЖЕННІ УКРАЇНИ}

У статті розглянуто окремі питання, пов'язані з особливостями використання відеоконференції у кримінальному провадженні в цілому та на окремих його стадіях, а також обтрунтовано власні висновки та пропозищіі, спрямовані на подальще вдосконалення кримінального прочесуального законодавства України щзодо зазначеної проблеми. Досліджено сутність, значення, переваги, сучасний стан та перспективи використання відеоконференції в кримінальному провадженні України. Проаналізовано підстави, прочесуальний порядок і сформульовано особливості використання відеоконферениії в кримінальному провадженні України.

Ключові слова: відеоконференція в кримінальному провадженні; допит иляхом проведення ВК; проиесуальній порядок та особливості використання ВК.

Постановка проблеми. Відеоконференція (далі - ВК) у кримінальному провадженні України, хоч і становить значний теоретичний та практичний інтерес, все-таки належить до категорії недостатньо досліджених наукових питань. Проблема застосування ВК у кримінальному провадженні комплексна та має фінансову, організаційну, технічну, правову, процесуальну і навіть психологічну сторони.

Крім того, недостатність досвіду застосування ВК у кримінальному провадженні в цілому та на окремих його стадіях, а іноді заперечення такого використання з боку практичних працівників негативно позначаються на ефективності іiі реалізації на практиці. Ще однією 3 причин такого стану $\epsilon$ відсутність фундаментальних теоретичних розробок щодо використання інформаційних технологій у кримінальному провадженні, зокрема i ВК. Унаслідок цього багато актуальних питань щодо використання ВК продовжують бути невирішеними на законодавчому рівні. Цей факт міг би залишитися простою констатацією, якби не перспектива застосування розглянутої технології в кримінальному провадженні України.

Аналіз останніх досліджень і публікацій. Питання, пов'язані з особливостями використання ВК у кримінальному провадженні в цілому та на окремих його стадіях, у кримінальних провадженнях, ускладнених іноземним елементом, перебували в центрі уваги науковців та практиків. 3 цього питання свою фахову позицію висловлювали Ю. П. Аленін, Т. С. Гавриш, І. В. Гловюк, В. Т. Маляренко, М. І. Пашковський та інші. 
Метою статті $є$ розгляд окремих дискусійних питань, пов'язаних з особливостями використанням ВК у кримінальному провадженні, а також обгрунтування власних висновків та пропозицій, спрямованих на подальше вдосконалення кримінального процесуального законодавства України щодо зазначених проблем.

Виклад основного матеріалу дослідження. Використанню ВК у кримінальному провадженні України присвячені ст.ст. 232, 336 та 567 Кримінального процесуального кодексу України (далі - КПК України). Якщо ст. 567 КПК України передбачає впровадження ВК у сферу міжнародної правової допомоги (проведення допиту за запитом компетентного органу іноземної держави шляхом ВК), то ст.ст. 232 та 336 КПК України регламентують використання ВК у національному кримінальному провадженні, неускладненому іноземним елементом. Зокрема, КПК України дозволяє проведення в режимі ВК таких дій: допиту осіб, у тому числі одночасного допиту двох чи більше вже допитаних осіб; пред'явлення для впізнання осіб та речей; проведення процесуальних дій у режимі ВК під час судового провадження.

Відомо, що зміст та форма кримінального провадження повинні відповідати загальним засадам кримінального провадження. Використання ВК у кримінальному провадженні незначною мірою впливає лише на засаду безпосередності дослідження показань, речей $\mathrm{i}$ документів. Це обумовлено тим, що проведення процесуальних дій у режимі ВК має деякі особливості, наприклад, застосування ВК дає змогу учасникам «бути присутніми» під час проведення слідчої (розшукової) дії або судового засідання, не перебуваючи безпосередньо у приміщенні органу досудового розслідування, суду, використовуючи термінали, які розташовані в інших приміщеннях.

Однак факт перебування підозрюваного, потерпілого, свідка або іншої особи в приміщенні органу досудового розслідування, суду або іншому місці проведення процесуальної, слідчої (розшукової) дії суттєво не впливає на здатність слідчого, прокурора, слідчого судді, суду відрізняти правдиві показання від неправдивих. Слідчий, прокурор, слідчий суддя або суд, отримуючи свідчення шляхом ВК, може враховувати майже всі нюанси поведінки, які виявляються під час особистого спілкування, тому використання ВК не має істотних недоліків у порівнянні з традиційними порядком проведення слідчих (розшукових) дій та не має кардинальних відмінностей в оцінці їх показань.

Отже, застосування ВК цілком узгоджується із засадами кримінального провадження, а сама ВК $є$ процесуальною формою використання інформаційних технологій у кримінальному провадженні та призначається для проведення заходу, учасники якого територіально віддалені один від одного, а тому спілкування між ними відбувається завдяки використанню технічних засобів зв'язку, що забезпечують передачу зображення і звуку в режимі реального часу.

Проведення слідчих (розшукових) дій у режимі ВК може застосовуватися за рішенням слідчого, прокурора, слідчого судді або суду в кожному конкретному випадку з урахуванням обставин кримінального провадження та наявності підстав, зокрема: неможливості безпосередньої участі певних осіб у досудовому провадженні за станом здоров'я або з інших поважних причин; необхідності забезпечення безпеки осіб; проведення допиту малолітнього або неповнолітнього свідка, потерпілого; необхідності вжиття таких заходів для забезпечення оперативності досудового розслідування; наявності інших підстав, визначених слідчим, прокурором, слідчим суддею достатніми.

Наведений перелік не $\epsilon$ вичерпним, оскільки в п. 5 ч. 1 ст. 232 КПК України зазначено про «наявність інших підстав, визначених слідчим, прокурором, слідчим суддею достатніми». Наявність хоча б однієї з названих обставин буде достатньою підставою для проведення слідчої (розшукової) дії в режимі ВК.

Аналогічні підстави, які передбачені в ч. 1 ст. 232 КПК України, вказані в ч. 1 ст. 336 КПК України щодо проведення судового провадження в режимі ВК.

Частина 2 ст. 232 КПК України передбачає, що рішення про проведення слідчої (розшукової) дії в режимі ВК приймається слідчим, прокурором, слідчим суддею (в разі 
проведення в режимі ВК допиту згідно зі ст. 225 КПК України) з власної ініціативи або за клопотанням сторони кримінального провадження чи інших учасників кримінального провадження.

Слідчий суддя приймає рішення про проведення допиту в режимі ВК з власної ініціативи або на підставі клопотання сторони кримінального провадження у виняткових випадках, пов'язаних із необхідністю отримання показань свідка чи потерпілого під час досудового розслідування, якщо через існування небезпеки для життя і здоров'я свідка чи потерпілого, їх тяжкої хвороби, наявності інших обставин, що можуть унеможливити їхній допит у суді або вплинути на повноту чи достовірність показань.

Відповідно до вимог КПК України, рішення слідчого та прокурора приймається у формі постанови, яка виноситься у випадках, визначених цим Кодексом, а також коли слідчий, прокурор визнає це доцільним. Частина 2 ст. 232 КПК України передбачає винесення спеціальної постанови (ухвали) про проведення слідчої (розшукової) дії в режимі ВК тільки в тому разі, коли проти цього заперечує сторона кримінального провадження чи потерпілий. Отже, якщо $є$ заперечення з боку сторони кримінального провадження чи потерпілого щодо проведення слідчої (розшукової) дії в режимі ВК, а слідчий, прокурор чи слідчий суддя вважають за необхідне проведення допиту чи впізнання в режимі ВК, вони повинні обгрунтувати своє рішення у вмотивованій постанові чи ухвалі.

Оскільки для підозрюваного давання показань є правом, а не обов'язком, проведення слідчої (розшукової) дії за його участю, коли він проти цього заперечує, не допускається.

Деякі особливості має процесуальний порядок проведення слідчих (розшукових) дій у режимі ВК, що відрізняють його від загального порядку проведення зазначених дій. Так, особливості процесуального порядку виконання слідчої (розшукової) дії в режимі ВК залежать від місця перебування особи, яка братиме участь у здійсненні слідчої (розшукової) дії за допомогою ВК. Така особа може знаходитися: у приміщенні, розташованому на території, яка перебуває під юрисдикцією органу досудового розслідування, або на території міста, в якому він розташований; у приміщенні, розташованому поза територією, яка перебуває під юрисдикцією органу досудового розслідування, або поза територією міста, в якому він розташований.

Учасниками слідчої (розшукової) дії в режимі ВК можуть бути свідки (у тому числі малолітні або неповнолітні), потерпілі, підозрювані. 3 огляду на те, що допит особи та пред'явлення для впізнання осіб чи речей у режимі ВК здійснюються за правилами ст.ст. 225227 та 228-229 КПК України, то в ході їх проведення можуть брати участь представник, захисник, спеціаліст, експерт, перекладач, педагог, психолог й інші особи, потреба в яких виникає у зв'язку з особливостями проведення слідчої (розшукової) дії.

Уважаємо, що проведення слідчих (розшукових) дій у режимі ВК не може здійснюватися щодо осіб, які страждають на дефекти мови, зору чи слуху.

Проведення допиту в режимі ВК за рішенням слідчого судді здійснюється згідно 3 положеннями ст. 232 та ч. 4-5 ст. 336 КПК України.

Під час проведення слідчої (розшукової) дії в режимі ВК слід забезпечити належну якість зображення і звуку, а також інформаційну безпеку. Тому слідчий, прокурор чи слідчий суддя повинні залучити до участі в проведенні слідчої (розшукової) дії в режимі ВК спеціаліста, який володіє спеціальними знаннями та навичками застосовування відповідних технічних засобів і технологій. Метою залучення спеціаліста $є$ забезпечення належної якості передачі зображення і звуку, безперервного і стабільного сеансу зв'язку та інформаційної безпеки ВК.

КПК України не дає визначення термінів «належна якість зображення і звуку» та «інформаційна безпека». Під належною якістю зображення слід розуміти зображення, що дає змогу ідентифікувати особу за ії зовнішністю всіма учасниками слідчої (розшукової) дії і зафіксувати це зображення технічними засобами з подальшою можливістю ідентифікації учасника слідчої (розшукової) дії за зображенням. Під належною якістю звуку передбачається звук, який дозволяє чітко і розбірливо розрізнити показання особи за іiі голосом усіма 
учасниками слідчої (розшукової) дії і зафіксувати його технічними засобами з подальшою можливістю ідентифікації учасника слідчої (розшукової) дії за його голосом. «Інформаційну безпеку телекомунікаційних мереж» визначають як здатність технічних засобів і технологій забезпечувати захист від знищення, перекручення, блокування інформації, iii несанкціонованого витоку або від порушення встановленого порядку іiї маршрутизації [1].

Перед початком проведення слідчої (розшукової) дії в режимі ВК необхідно переконатися, що ніщо не перешкоджає особі вільно давати показання, заявляти клопотання, надавати докази, що сприяє уникненню так званого впливу «поза кадром». Проведення слідчої (розшукової) дії у режимі ВК повинно бути організоване так, щоб було видно не тільки ії учасників, але й усе приміщення, у якому вона здійснюється, а також усіх осіб, що беруть участь або присутні під час іiї проведення, з метою спостереження за їхньою реакцією на конкретні показання або поставлені запитання.

Учасникам слідчої (розшукової) дії повинна бути забезпечена можливість ставити запитання та отримувати відповіді осіб, які беруть участь у слідчій (розшуковій) дії в режимі ВК, реалізовувати інші надані їм процесуальні права та виконувати процесуальні обов'язки, передбачені КПК України.

Оскільки відповідно до ч. 6 ст. 224 КПК України допитувана особа має право використовувати під час допиту власні документи й нотатки, якщо іiї показання пов'язані 3 будь-якими обчисленнями та іншими відомостями, які важко зберегти в пам'яті, то в ході допиту в режимі ВК потрібно забезпечити можливість передати інформацію, яка міститься в таких документах і нотатках. Для цього в місці перебування допитуваної особи слід установити сканер, а в місці перебування слідчого, прокурора, слідчого судді та інших учасників слідчої (розшукової) дії - принтер.

3 метою забезпечення безпеки особи вона може бути допитана в режимі ВК з такими змінами зовнішності та голосу, за яких ї̈ неможливо було б упізнати. Для цього застосовуються спеціальні акустичні ефекти, що змінюють голос, а також візуальні перешкоди технічного характеру, або іншим чином змінюється зовнішність особи. У такому разі обмін відеоінформацією в режимі ВК не здійснюється, а отримана від допитуваної особи аудіоінформація змінюється за допомогою програмно-апаратних засобів [2].

Слід зауважити, що під час проведення вербальних слідчих (розшукових) дій у режимі ВК знижується рівень комунікативного контакту з його учасником, встановлення якого $\epsilon$ важливим складником ефективності слідчої (розшукової) дії. Ця обставина зумовлена необхідністю одержати особисте, безпосереднє враження від допитуваного та врахувати всі нюанси його поведінки під час давання показань, а також відсутністю прямого (тобто віч-навіч) спілкування слідчого, прокурора або слідчого судді з учасником слідчої (розшукової) дії; технічною складністю передачі всього обсягу інформації; відсутністю сприятливої для спілкування атмосфери слідчої (розшукової) дії.

Зниження рівня комунікативного контакту під час проведення слідчих (розшукових) дій у режимі ВК не варто розглядати як суттєву перешкоду для іï використання у кримінальному провадженні. Вважаємо, що ВК слід визначати як «технічного посередника» між слідчим, прокурором, слідчим суддею - 3 одного боку, і допитуваним - 3 іншого. ВК передбачає мінімум впливу на безпосереднє враження від допитуваного, не створює нездоланного бар'єру для ефективної комунікації між учасниками слідчої (розшукової) дії.

У ч. 1 ст. 104 КПК України встановлюється, що у випадках, визначених цим Кодексом, хід і результати проведення процесуальної дії фіксуються у протоколі. Стаття 232 КПК України не містить прямої вказівки щодо фіксації ходу й результатів допиту, проведеного в режимі ВК, у протоколі. Водночас у КПК України є низка непрямих вказівок, які свідчать про необхідність складання протоколу допиту, проведеного в режимі ВК, зокрема: ч. 2 ст. 104 КПК України передбачає, що текст показань може не вноситися до відповідного протоколу, якщо допит фіксувався за допомогою технічних засобів; у такому разі в протоколі зазначається, що показання зафіксовані на носії інформації, який додається до нього; п. 3 ч. 2 ст. 105 КПК України встановлює, що додатком до протоколу є відеозапис процесуальної дії, 
який долучається до нього; ч. 5 ст. 224 КПК України визначає, що під час допиту може застосовуватися відеозапис. Отже, під час проведення допиту в режимі ВК має складатися протокол.

Частина 9 ст. 232 КПК України передбачає, що хід і результати слідчої (розшукової) дії, проведеної в режимі ВК, одержують певну фіксовану форму за допомогою технічних засобів відеозапису. Технічні засоби відеозапису ходу і результатів слідчої (розшукової) діїце сукупність програмно-апаратних засобів та приладів, що забезпечують належне фіксування, зберігання, копіювання (дублювання) і використання інформації, яка відображає процес ВК [2]. Відео- та аудіозаписи, які сформовані безпосередньо під час проведення ВК і записані за допомогою технічних засобів відеозапису, $\epsilon$ вихідним матеріалом для виготовлення робочої та архівної копій.

У матеріалах кримінального провадження обов'язково зберігаються оригінальні примірники технічних носіїв інформації зафіксованої процесуальної дії, резервні копії яких зберігаються окремо.

Згідно 3 ч. 6 ст. 107 КПК України незастосування технічних засобів фіксування кримінального провадження в обов'язкових випадках призводить до недійсності відповідної процесуальної дії та отриманих унаслідок їі вчинення результатів.

Висновки. Використання ВК у кримінальному провадженні незначною мірою впливає лише на засаду безпосередності дослідження показань, речей і документів. Це обумовлено тим, що проведення процесуальних дій у режимі ВК має деякі особливості, наприклад, застосування ВК дає змогу учасникам «бути присутніми» під час проведення слідчої (розшукової) дії або судового засідання, не перебуваючи безпосередньо в приміщенні органу досудового розслідування, суду, використовуючи термінали, які розташовані в інших приміщеннях. Хід і результати слідчої (розшукової) дії або судового засідання, проведених у режимі ВК, відображаються як у пам'яті присутніх і тих осіб, що брали участь у їхньому проведенні, так і одержує певну фіксовану форму за допомогою технічних засобів відеозапису.

Використання ВК у судовому провадженні не суперечить змагальності, що передбачає самостійне обстоювання стороною обвинувачення і стороною захисту їхніх правових позицій, прав, свобод і законних інтересів (ст. 22 КПК України).

Факт перебування підсудного, потерпілого, свідка, експерта або іншої особи в приміщенні суду або іншому місці проведення процесуальної дії суттєво не впливає на здатність суду, прокурора або захисника відрізняти правдиві показання від неправдивих. Суд, отримуючи показання в режимі ВК, може враховувати майже всі нюанси поведінки, які виявляються під час особистого спілкування, тому використання ВК цілком узгоджується із засадою безпосередності дослідження доказів (ст. 23 КПК України) та не має суттєвих недоліків у порівнянні з традиційними способами одержання показань, не створює нездоланного бар'єру для ефективної комунікації між учасниками процесуальної дії, не має кардинальних відмінностей в оцінці показань. Підсудний, потерпілий, свідок та інші особи доступні суду, стороні захисту та стороні обвинувачення і можуть бути допитані за всіх обставин, що мають значення для кримінального провадження. Особа безпосередньо не знаходиться в приміщенні, у якому перебуває суд, однак іiі віддалена присутність забезпечується ВК. Вона надає можливість заявляти клопотання, подавати докази, брати участь у їхньому дослідженні.

Використання ВК як заходу безпеки може бути пов'язане з обмеженням процесуальних гарантій, прав інших учасників кримінального провадження. У зв'язку з цим уважаємо за необхідне звернути увагу на таке: використання розглянутого процесуального заходу безпеки в кримінальному провадженні у разі дотримання певних умов $\epsilon$ сумісним із засадою безпосередності дослідження доказів і правом підозрюваного (обвинувачуваного) на захист; проведення допиту в режимі ВК в умовах, що виключають ідентифікацію особи, $\epsilon$ допустимим, якщо зі справжніми даними особи, щодо якої здійснюється захист, під час досудового розслідування або судового розгляду можуть ознайомитися прокурор, що здійснює нагляд за додержанням законів і суд; показання анонімних свідків мають бути 
отримані судом із дотриманням засади змагальності. Обвинувачуваний (підсудний) при цьому повинен мати можливість бути присутнім під час допиту та спостерігати за поведінкою свідка. Недотримання цього порядку є порушенням права конфронтації, передбаченого п. «d» ч. 3 ст. 6 Конвенції про захист прав людини й основоположних свобод від 04.11.1950 р. [3]. Надання обвинувачуваному можливості ставити запитання анонімним свідкам у письмовий формі через суддю є недостатньою мірою для забезпечення права обвинувачуваного на допит; обгрунтування обвинувачення виключно на показаннях анонімних свідків $є$ недопустимим. Вони повинні бути підтверджені іншими доказами; показання анонімного свідка підлягають ретельній перевірці; рішення про проведення допиту в режимі ВК в умовах, що виключають ідентифікацію свідка, потерпілого, іншого учасника процесу, повинно бути обгрунтованим.

Порядок проведення судового провадження в режимі ВК має деякі особливості, що відрізняють його від загального порядку судового розгляду. Під час спілкування за допомогою ВК необхідно переконатися, що ніщо не перешкоджає особі вільно давати показання, заявляти клопотання, надавати докази тощо. Ця обставина має суттєве значення для допустимого використання в кримінальному провадженні доказів, отриманих завдяки ВК. Проведення процесуальної дії в режимі ВК повинно бути організоване так, щоб було видно не тільки їі учасників, але й усе приміщення, у якому вона здійснюється, а також усіх осіб, що беруть участь або присутні під час його проведення, з метою спостереження за їхньою реакцією на конкретні показання або поставлені питання. Учасникам кримінального провадження має бути забезпечена можливість чути та бачити хід судового провадження, ставити запитання та отримувати відповіді, реалізовувати інші надані їм процесуальні права й виконувати процесуальні обов'язки, передбачені КПК України.

Сучасні технології ВК дають змогу бачити не тільки учасника процесуальної дії, але й усе приміщення, у якому він перебуває, що дозволяє уникнути так званого впливу «поза кадром».

\section{Список використаних джерел}

1. Про телекомунікації : Закон України від 18.11.2003 p. № 1280-IV. URL: https://zakon.rada.gov.ua/laws/show/1280-15 (дата звернення: 17.02.2021).

2. Інструкція про порядок роботи з технічними засобами відеозапису ходу i результатів процесуальних дій, проведених у режимі відеоконференції під час судового засідання (кримінального провадження) : затв. наказом Державної судової адміністрації України від 15.11.2012 р. № 155. URL: https://zakon.rada.gov.ua/rada/show/v0155750-12 (дата звернення: 17.02.2021).

3. Конвенція про захист прав людини й основоположних свобод від 04.11.1950 p. URL: https://zakon.rada.gov.ua/laws/show/995_004 (дата звернення: 17.02.2021).

\section{References}

1. Pro telekomunikatsii : Zakon Ukrainy vid 18.11.2003 r. № 1280-4 [On
[On Telecommunications]. URL: https://zakon.rada.gov.ua/laws/show/1280-15 (data zvernennia: 17.02.2021) [in Ukrainian].

2. Instruktsiia pro poriadok roboty $\mathrm{z}$ tekhnichnymy zasobamy videozapysu khodu i rezultativ protsesualnykh dii, provedenykh u rezhymi videokonferentsii pid chas sudovoho zasidannia (kryminalnoho provadzhennia) : zatv. nakazom Derzhavnoi sudovoi administratsii Ukrainy vid 15.11.2012 r. № 155 [Instructions on the procedure for working with technical means of video recording of the course and results of procedural actions carried out in the mode of videoconference during the court session (criminal proceedings)]. URL: https://zakon.rada.gov.ua/rada/show/v0155750-12 (data zvernennia: 17.02.2021) [in Ukrainian]. 
3. Konventsiia pro zakhyst prav liudyny i osnovopolozhnykh svobod vid 04.11.1950 r. [Convention for the protection of human rights and fundamental freedoms]. URL: https://zakon.rada.gov.ua/laws/show/995_004 (data zvernennia: 17.02.2021) [in Ukrainian].

Smyrnov Maksym,

$\mathrm{PhD}$ in Law, Associate Professor

(National University «Odessa Law Academy», Odessa)

ORCID: https://orcid.org/0000-0002-4563-5902

\section{VIDEOCONFERENCE AS A PROCEDURAL FORM OF USING INFORMATION TECHNOLOGIES IN CRIMINAL PROCEEDINGS OF UKRAINE}

The article deals with specific controversial issues concerning features of using videoconferencing in criminal proceedings in general as well as at its specific stages; also own conclusions and propositions are justified which are aimed at further development of criminal procedural legislation of Ukraine with the regard to the questions raised. The essence, meaning, advantages, current state, and perspectives of using videoconferencing in criminal proceedings of Ukraine and the area of international cooperation among the states in criminal justice are examined. The state of legal regulation of using videoconferencing in criminal proceedings is analyzed. Code of Criminal Procedure of Ukraine provides for using videoconferencing both in criminal proceedings of Ukraine and criminal proceedings with a foreign element. Based on the analysis of grounds and procedure of video-conferencing features of its usage both in criminal proceedings of Ukraine and in the area of international cooperation among the states in criminal justice are identified. Videoconferencing can be used based on the decision of an investigator, prosecutor, investigative judge, or court in each case taking into account circumstances of criminal proceedings and subject to grounds provided for by the Code of Criminal Procedure of Ukraine. Before the start of investigative (search) action or court session using video-conferencing one shall ensure that nothing prevents a person from giving testimony, making motions, providing evidence, etc. This fact is essential for the admissibility of evidence used in criminal proceedings obtained using videoconferencing. Conducting requested procedural actions by video-conferencing ensure that an accused person, a victim, and other participants have an opportunity to express themselves on the raised issues, make arguments aimed to rebut the conclusions of the opposing party, provide evidence and make motions during pre-trial investigation or trial. Specificities of conducting a questioning using videoconferencing in the area of international cooperation as well as advantages of obtaining testimony from individuals put into custody or serving a sentence in a foreign state using videoconferencing compared to traditional means are formulated. The issue of interrelation between videoconferencing and principles of criminal proceedings is examined and it is showed that using videoconferencing is fully consistent with principles of criminal proceedings. Videoconferencing is one of the procedural forms of using information technologies in criminal proceedings and is used to conduct an action, participants of which are geographically separated one from another and thus communication among them are conducted using the communication technologies that support real-time image and voice transmission.

Key words: videoconferencing in criminal proceedings; questioning by having a videoconference; procedure and features of using videoconferencing. 


\title{
РОЗДІЛ V \\ ПІДГОТОВКА ФАХІВЦІВ СИСТЕМИ ПРОФЕСІЙНОЇ ЮРИДИЧНОЇ ОСВІТИ В ЗАКЛАДАХ ВИЩОЇ ОСВІТИ ЗІ СПЕЦИФІЧНИМИ УМОВАМИ НАВЧАННЯ
}

\author{
УДК: 378.6:37.014.24:061.2
}

DOI: https://doi.org/10.32366/2523-4269-2021-75-2-182-191

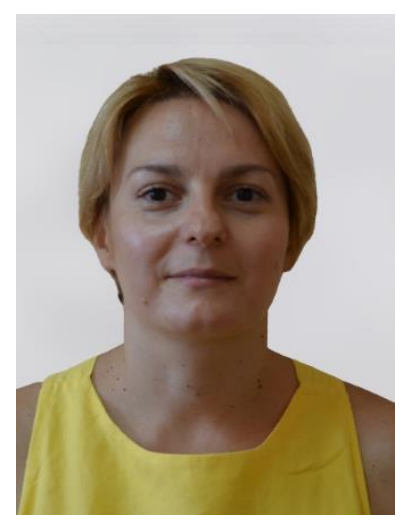

\section{Сальнікова Наталія Валеріївна,} кандидат історичних наук

(Донецький державний університет внутрішніх справ, м. Маріуполь)

ORCID: https://orcid.org/0000-0003-4931-0491

\section{ЗАБЕЗПЕЧЕННЯ ЯКОСТІ ОСВІТИ У ВІДОМЧИХ ЗВО: СПІВПРАЦЯ 3 МІЖНАРОДНИМИ ГРОМАДСЬКИМИ ОРГАНІЗАЦІЯМИ}

Розвиток якісної вищої освіти залишається пріоритетом сучасної державної політики Украӥни. Для впровадження стандартів якості вищої освіти, які прийняті в Свропейському просторі вищої освіти, украӥнські відомчі університети адаптують європейський досвід, формуючи внутрішню систему забезпечення якості. Одним з ї елементів $\epsilon$ співпраия із зовнішніми стейкхолдерами, зокрема громадськими організаціями різного рівня. На основі аналізу прикладів взаємодії відомчих закладів вищої освіти України та міжнародних громадських організащій, розміщених на сайтах відповідних закладів, зроблено висновок про дискретний характер співпраці та недостатній ступінь ї̈ висвітлення.

Ключові слова: $\quad$ вища освіта; забезпечення якості; внутрішнє забезпечення якості; відомчі університети; міжнародні організації.

Постановка проблеми. Професійна самореалізація людини здійснюється, окрім іншого, на основі знань, які було отримано в закладі вищої освіти (далі - 3ВО). Вища освіта - це соціальний інститут, що має принципове значення не лише для професійного розвитку окремого індивіда, а і є ключовим елементом соцієтального розвитку сучасного суспільства. Особливість вищої освіти як соціального інституту полягає у можливості, з одного боку, відтворювати та передавати, а 3 іншого - створювати нові знання, норми та цінності суспільства, що гарантує сталий розвиток, збереження традицій та розробку інновацій.

Забезпечення сталого функціонування університетів, їх розвиток та підвищення якості освітніх послуг $\epsilon$ актуальним для всіх 3ВО, у тому числі для закладів із вузькою спеціалізацією. Для досягнення зазначених цілей було розширено коло учасників, які здатні впливати на інститут вищої освіти. Так, сучасна політика у сфері вищої освіти для забезпечення якості передбачає залучення до розробки освітніх програм, навчальної діяльності, перегляду навчальних матеріалів, проведення семінарських і практичних занять та інших видів діяльності різних груп учасників, серед яких можуть бути: експерти, аналітики, практики, представники громадських об’єднань, місцевих громад та місцевих 
муніципалітетів, роботодавці, батьки абітурієнтів та здобувачів вищої освіти, випускники тощо. Це дослідження присвячено вивченню ролі одного з таких учасників, як громадські об'єднання, бо саме вони є організованими формами стейкхолдерів, що здатні здійснювати системний вплив на розвиток університетів. У сучасній науковій літературі замість терміна «учасник» частіше використовують «стейкхолдер». Поняття «стейкхолдер» наведено у Стандартах і рекомендаціях щодо забезпечення якості у Свропейському просторі вищої освіти $[1$, с. 7]. Цей термін тлумачиться як «учасники (суб'єкти) у межах закладу, включаючи студентів і персонал, а також зовнішні стейкхолдери, такі як працедавці та зовнішні партнери закладу» [2, с. 308].

Поняття «громадське об'єднання» наведено у ст. 1 Закону України «Про громадські об'єднання»: «громадська організація - це громадське об'єднання, засновниками та членами (учасниками) якого є фізичні особи» [3].

Аналіз останніх досліджень і публікацій. Актуальність дослідження впливу неурядових організацій на функціонування та забезпечення якості освіти вищої школи підтверджується низкою міжнародних документів.

Українські дослідники, аналізуючи джерелознавчу базу з цього питання, звертають увагу на вплив різних стейкхолдерів на вищу освіту. Так, у частині звіту «Бенчмаркінг ефективності системи вищої освіти» під назвою «Вища освіта та ширший соціальний та економічний контекст» зазначено, що вища освіта $є$ частиною середовища, у якому вона існує, та має ключове значення для соціально-економічного розвитку, будучи пов'язаною з різними галузями та стейкхолдерами [4, с. 309].

У моніторинговому звіті Світового банку щодо розвитку українських 3ВО «Review of the education sector of Ukraine: moving towards effectiveness, equity and efficiency» («Дослідження сфери освіти в Україні: до більшої результативності, справедливості та ефективності». - H. C.) наголошено на необхідності розширення кола дійсних учасників процесу реформування вищої школи України, у тому числі залучення представників громадських організацій [5].

У звіті «Education at a Glance. OECD Indicators» («Погляд на освіту 2020. Індикатори Організації економічного співробітництва та розвитку». - H. C.) у розділі «Access to education, participation and progress» («Доступ до освіти, участь та розвиток». - H. C.) вказано, що у Європейському просторі вищої освіти участь у забезпеченні та моніторингу якості вищої освіти беруть і спеціалізовані агентства, до яких належать міжнародні громадські організації [6].

Актуальність вивчення впливу громадських організацій на забезпечення якості вищої освіти підтверджено також активною науковою дискусією із зазначеної проблематики. Наявність вітчизняних та закордонних наукових праць із дослідження проблем функціонування вищої освіти та забезпечення ії̈ якості свідчить про актуальність та стійкий науковий інтерес до цієї тематики. Серед українських спеціалістів дослідженням відповідних процесів займаються С. Калашнікова, В. Луговий, О. Слюсаренко, Ж. Таланова та інші, які вивчають особливості функціонування системи вищої освіти України та механізми забезпечення іiї якості. Вплив різних стейкхолдерів, а саме громадських організацій, на якість вищої освіти грунтовно досліджується такими закордонними вченими, як І. Блеклі, С. Епп, Д. Барраган, Б. Гілфілан та інші.

Оцінюючи вітчизняний стан розвитку забезпечення якості вищої освіти, українські дослідники В. Луговий та Ж. Таланова зазначають: «В Україні культура якості, що базується на збалансованому поєднанні стандартів забезпечення мінімуму і стандартів покращення максимуму якості вищої освіти із тенденцією домінування других, знаходиться на початковій стадії становлення». Водночас світова практика «в умовах розширення автономії університетів» демонструє «тенденцію до поширення стандартів другого роду, що базуються на застосуванні рейтингів та акредитації реалізації освітніх програм і діяльності закладів освіти» $[7$, с. 68$]$.

Описуючи сучасні українські ЗВО, С. Калашникова стверджує, що університети діють 
в умовах відкритості та партнерства на основі нової моделі управління вищою освітою (врядування), яка «включає багато рівнів і багато акторів (учасників); правила, процедури i механізми їхньої взаємодії для досягнення спільних цілей» і «спричиняє зміну ролі держави в управлінні вищою освітою (від регулятора до фасилітатора) та делегування / перерозподіл іiі владних повноважень серед нових акторів (учасників) процесу управління» [8, с. 18].

Українська дослідниця взаємодії громадських організацій та закладів вищої освіти К. Трима вказує на те, що «закордонний досвід функціонування незалежних громадських організацій для самодіагностики, самооцінювання та обміну досвідом, які не є державними структурами та агенціями, є поширеною практикою в багатьох країнах світу» [9, с. 108]. Залучення громадських організацій до забезпечення якості вищої освіти сприяє «утворенню нових суспільних форм контролю за освітніми просторами. Участь громадських організацій в освітній діяльності стає інструментом громадського контролю, що об'єктивно підвищує якість діяльності закладів вищої освіти, робить ії більш прозорою та підзвітною суспільству, тому що різні стейкхолдери отримують можливість брати участь у процесі формування змісту та функціонування системи освіти» [9, с. 109].

Б. Гілфілан та А. Фі в роботі «Shaping participation: an international NGO implementing a government participation policy» («Формування участі: міжнародна неурядова організація, що реалізує політику взаємодії з урядом». - H. C.) визначають механізми впливу неурядових організацій на функціонування закладів освіти через спільні програми та проєкти для задоволення потреб місцевих громад [10].

Аналіз історіографії та джерел підтверджує активну академічну дискусію щодо проблеми впливу стейкхолдерів на розвиток вищої освіти, що актуалізує дослідження особливостей впливу громадських організацій на забезпечення якості вищої освіти, зокрема у відомчих закладах вищої освіти, тому що саме цей аспект недостатньо висвітлено в науковій літературі.

Формування мети статті. Метою статті $є$ аналіз впливу міжнародних громадських організацій, залучених до правоохоронної діяльності, зокрема до освіти правоохоронців, на забезпечення якості вищої освіти у спеціалізованих 3ВО України.

Виклад основного матеріалу. Визначення поняття якості вищої освіти подано в Національному глосарії вищої освіти: «Якість вищої освіти - це характеристика вищої освіти, що відображає відповідність результатів навчання, освітніх процесів та інституційних умов актуальним цілям розвитку особи і суспільства. Якість вищої освіти є ключовим поняттям Болонського процесу. 3 метою ії забезпечення розроблено Рамку кваліфікацій Свропейського простору вищої освіти (2005р.), Свропейські стандарти і рекомендації щодо забезпечення якості вищої освіти (2005р.), утворено Європейську асоціацію забезпечення якості вищої освіти (2004р.) та Європейський реєстр забезпечення якості вищої освіти (2008р.)» [11, с. 87].

Закон України «Про освіту» в редакції 2017 р. (далі - Закон) надає можливість здійснювати громадський нагляд (контроль) за забезпеченням якості вищої освіти. Згідно зі ст. 71 Закону суб'єктами громадського контролю можуть бути «громадські об'єднання та інші інститути громадянського суспільства, установчими документами яких передбачено діяльність у сфері освіти та/або соціального захисту осіб з інвалідністю, професійними об'єднаннями педагогічних і науково-педагогічних працівників, об'єднаннями здобувачів освіти, об'єднаннями батьківських комітетів та органами, до яких вони делегують своїх представників» [12]. Компетенцією громадських об'єднань $\epsilon$ «право отримувати у встановленому законодавством порядку доступ до інформації на всіх етапах прийняття рішень у сфері вищої освіти і науки, вносити пропозиції та зауваження до них та погоджувати прийняття визначених законом рішень» [13].

Цей Закон регулює і діяльність закладів вищої освіти Міністерства внутрішніх справ України (далі - МВС України), оскільки вони є державними освітніми закладами, які «засновані і діють згідно із законодавством України, реалізовують відповідно до наданої ліцензії (ліцензій) освітньо-професійні програми підготовки фахівців, забезпечують навчання, виховання та професійну підготовку осіб з урахуванням нормативних вимог у 
галузі вищої освіти з метою задоволення освітніх потреб особи, суспільства і держави, а також здійснюють наукову і науково-технічну діяльність» [14].

Основною метою діяльності спеціалізованих університетів МВС України є створення всіх необхідних умов для підготовки профільних фахівців для органів і підрозділів МВС України.

Процес забезпечення та моніторингу якості вищої освіти у спеціалізованих закладах вищої освіти не відрізняється від тих підходів, які діють у стандартних українських 3ВО, та передбачає здійснення таких заходів: «щорічне оцінювання здобувачів вищої освіти шляхом проведення зрізів знань; перевірка рівня викладання дисциплін, особливо молодими викладачами (проведення опитування курсантів, слухачів і студентів); посилення вимог до якості підготовки кваліфікаційних робіт усіх рівнів та діяльність щодо запобігання академічному плагіату; обов'язкове стажування науково-педагогічних працівників» [15].

Вивчення тексту документів, якими регламентується внутрішня система забезпечення якості (Положення про систему внутрішнього забезпечення якості освітньої діяльності та якості вищої освіти Харківського національного університету внутрішніх справ [16], Львівського державного університету внутрішніх справ [17], Дніпропетровського державного університету внутрішніх справ [18], Донецького юридичного інституту Міністерства внутрішніх справ України (нині - Донецький державний університет внутрішніх справ. - H. C.) [19] та Одеського державного університету внутрішніх справ [20]), надає підстави стверджувати, що українські спеціалізовані заклади вищої освіти орієнтовані на взаємодію з громадськими об'єднаннями через наявність у відповідних положеннях норми щодо співпраці ЗВО зі стейкхолдерами, серед яких є міжнародні та українські громадські організації, діяльність яких стосується спеціалізованої освіти. Але варто зауважити, що в розглянутих положеннях $[16 ; 17 ; 17 ; 19 ; 20]$ не визначено сам механізм та правила взаємодії відомчих університетів та громадських організацій.

Аналіз інформації, що міститься на сайтах спеціалізованих ЗВО України за період 3 01.09.2020 р. по 01.03.2021 р., а саме матеріалів відділу міжнародної співпраці та розділу «Новини», дає змогу виокремити низку міжнародних організацій, з якими в різних сферах, зокрема щодо забезпечення якості освіти, співпрацюють спеціалізовані заклади вищої освіти України. Доцільно розглянути особливості кожної з міжнародних організацій.

Асоиіачія європейських полічейських коледжів (курсив мій. - H. С.) є добровільним об'єднанням профільних навчальних закладів поліції країн ЄС та сусідніх держав, що була створена 25 січня 1996 році у м. Брюссель, до іï складу зараз входить 53 заклади освіти з країнчленів ЄС та сусідніх країн [21]. Ця громадська організація виконує такі функції: координує діяльність і співпрацю щодо підготовки поліцейських у Європі; проводить дослідження та розробки у сфері поліцейської освіти; сприяє поширенню найкращих практик з підготовки поліцейських кадрів; поглиблює зв'язки між закладами освіти відповідного профілю; організовує онлайн-навчання [22].

На сайтах зазначених вище ЗВО наявна інформація про членство відповідних закладів вищої освіти в цій організації, здійснення спільних наукових заходів (круглих столів та конференцій), поширення сучасної наукової та науково-методичної літератури 3 правоохоронної проблематики, проведення онлайн-заходів для правоохоронців-практиків та здобувачів вищої освіти.

Європейський поліиійний коледж - агентство Європейського Союзу, що об’єднує старших офіцерів національних поліцій країн $\mathrm{CC}$, повноваженнями яких $\epsilon$ боротьба 3 транскордонною злочинністю, забезпечення громадської безпеки і правопорядку (курсив мій. - H. C.). До функцій організації належить: поширення інформації про особливості європейської юстиції; підготовка офіцерів поліції у країнах-кандидатах на вступ до ЄС; підготовка офіцерів у країнах-членах Європейського Союзу [23].

На сайтах Дніпропетровського державного університету внутрішніх справ, Донецького державного університету внутрішніх справ, Львівського державного університету внутрішніх справ наявна інформація про укладання партнерських договорів із вказаною організацією. 
Міжнародна асоџіаџія керівників у сфері стандартів та підготовки правоохоронних органів (курсив мій. - H. С.) підтримує інноваційний розвиток професійних стандартів громадської безпеки через спеціалізовані дослідження, надає допомогу державам та міжнародним партнерам для формування дієвих оборонних стандартів, сприяє навчанню персоналу, залученого до забезпечення громадської безпеки. Організація регулярно проводить зустрічі для обміну досвідом у сфері поширення стандартів кримінального правосуддя та навчання [24]. На сайтах відомчих університетів $\epsilon$ інформація про їхню участь у функціонуванні української секції міжнародної організації; обмін навчальними та аналітичними матеріалами, а також спільна розробка та реалізація освітніх програм для підготовки поліцейських і підвищення рівня їхньої кваліфікації, проведення навчання для керівників правоохоронних інституцій, створення кваліфікаційних вимог до співробітників правоохоронних органів, вивчення сучасних моделей управління поліцейськими організаціями.

Міжнародна асоціація начальників поліиії - це найбільша у світі професійна асоціація керівників поліції, яка налічує понад 30000 членів у більш ніж 160 країнах світу (курсив мій. - H. C.). Ця громадська організація орієнтована на підвищення рівня безпеки громади через дотримання стандартів професійної діяльності поліцейських [25]. Організація є видавцем журналу «The Police Chief» («Начальник поліції». - H. C.) для працівників правоохоронних органів, завдяки якому поширює відповідні напрацювання, а також є організатором щорічної конференції IACP (Міжнародної асоціації начальників поліції. - H. C.), найбільшої у світі освітньої та технологічної виставки.

На сайті Львівського державного університету внутрішніх справ указано про започаткування програми залучення поліцейських до вивчення іноземних мов, щоб розширювати співробітництво з міжнародними партнерами у сфері боротьби зі злочинністю.

Міжнародна полічейська організація - міжнародна неурядова організація, яка об'єднує 372 тисячі дійсних або колишніх працівників правоохоронних органів зі 100 країн світу (курсив мій. - Н. С.). До функцій організації належить: зміцнення зв'язків між правоохоронцями різних країн, сприяння міжнародному співробітництву в соціальній, культурній та професійній сферах, формування позитивного іміджу поліції [26].

У 1996 р. було створено українську секцію Міжнародної поліцейської асоціації (далі УС МПА), яка об'єднує близько 7 тисяч членів, серед котрих представники українських спеціалізованих ЗВО. Український осередок організовує різноманітні заходи для поглиблення професійних навичок правоохоронців.

На сайтах розглянутих відомчих закладів вищої освіти в розділі «Новини» $є$ посилання на участь УС МПА у проведенні локальних заходів (круглих столів, спільних виступів тощо).

На основі аналізу інформації з офіційних сайтів відомчих закладів вищої освіти України співпрацю ЗВО та міжнародних громадських організацій можна охарактеризувати як таку, що має дискретний характер.

Міжнародні громадські організації $\epsilon$ партнерами та співорганізаторами університетських заходів, проте детальна інформація, яка дозволяє оцінити внесок громадських організацій у діяльність закладів вищої освіти та визначити їхній потенціал щодо вдосконалення освітніх програм, переважно відсутня. Але така співпраця виконує важливу функцію: міжнародні громадські організації професійного спрямування здатні забезпечити обмін найкращими практиками у профільній правоохоронній освіті.

Висновки й перспективи подальших розвідок. Проблема забезпечення якості вищої освіти у спеціалізованих закладах вищої освіти залишається одним із пріоритетних напрямів освітньої політики держави. Ефективне забезпечення якості освітніх послуг у таких 3ВО передбачає впровадження показників якості освіти, що використовуються в інших країнах світу, насамперед у Свропейському просторі вищої освіти.

Роль різних стейкхолдерів, зокрема представників громадських організацій (наприклад професійних асоціацій правників), у процесі забезпечення якості вищої освіти $\epsilon$ важливим інструментом поширення інноваційних практик та стандартів у галузі освіти. Аналіз новин, 
розміщених на сайтах відповідних ЗВО, підтверджує тенденцію щодо поглиблення зв'язків спеціалізованих 3ВО з міжнародними громадськими організаціями, діяльність яких стосується правоохоронної справи.

Інформація про співпрацю ЗВО та громадських організацій є також доступною на сайтах відповідних спеціалізованих закладів вищої освіти та надає загальне уявлення про спільні наукові заходи та освітню діяльність, тренінги, конференції і круглі столи, підвищення кваліфікації окремих працівників.

Серед подальших наукових розвідок доцільним $є$ моніторинг впливу міжнародних громадських організацій на забезпечення якості вищої освіти у спеціалізованих 3ВО та розробка окремих нормативних документів у закладах освіти для систематизації цієї взаємодії. На нашу думку, адаптація позитивної практики та участь у заходах міжнародних організацій $\mathrm{i}$ надалі сприятиме поліпшенню забезпечення якості вищої освіти в українських відомчих закладах вищої освіти.

\section{Список використаних джерел}

1. Стандарти і рекомендації щодо забезпечення якості в Свропейському просторі вищої освіти. Київ, 2015. 35 с.

2. Трима К. Вплив громадських організацій на політику якості вищої освіти: аналіз провідного зарубіжного та вітчизняного досвіду. Аналіз провідного вітчизняного та зарубіжного досвіду щзодо оцінювання якості вищої освіти в умовах євроінтеграції: аналітичні матеріали у двох частинах. Київ : Прінтеко, 2020. Ч. 1. С. 308-315.

3. Про громадські об'єднання : Закон України від 22.03.2012 р. № 4572-VI. URL: https://zakon.rada.gov.ua/laws/show/4572-17 (дата звернення: 21.01.2021).

4. Трима К. Вплив громадських організацій на політику якості вищої освіти: аналіз провідного зарубіжного та вітчизняного досвіду. Аналіз провідного вітчизняного та зарубіжного досвіду щуодо оцінювання якості вищої освіти в умовах євроінтеграції: аналітичні матеріали у двох частинах. Київ : Прінтеко, 2020. Ч. 2. С. 308-315.

5. Review of the education sector of Ukraine: moving towards effectiveness, equity and efficiency. P.77. URL: https://openknowledge.worldbank.org/handle/10986/32406 (дата звернення: 27.03.2021).

6. OECD (2020), Education at a Glance 2020: OECD Indicators, OECD Publishing, Paris. URL: https://www.oecd-ilibrary.org/education/education-at-a-glance-2020_69096873-en (дата звернення: 30.04.2021).

7. Аналіз провідного вітчизняного та зарубіжного досвіду гуманізації вищої освіти як засобу забезпечення iї якості : аналітичні матеріали (частина II) / за ред. В. Лугового, Ж. Таланової. К. : ІВО НАПН України, 2016. 111 с.

8. Розвиток інституційного потенціалу університетів у контексті глобального лідерства. Київ : Інститут вищої освіти НАПН України, 2017. 205 с.

9. Трима К. Вплив громадських організацій на забезпечення якості вищої освіти. Молодий вчений. 2018. № 10. С. 107-114.

10. Gilfillan B., Fee A. Shaping participation: an international NGO implementing a government participation policy. Development in Practice. 2017. 27:8. P. 1035-1049.

11. Національний освітній глосарій: вища освіта. К. : ТОВ «Видавничий дім «Плеяди», 2011. 100 с.

12. Про вищу освіту : Закон України від 01.07.2014 p. № 1556-VII. URL: https://zakon.rada.gov.ua/laws/show/1556-18 (дата звернення: 28.01.2021).

13. Про освіту : Закон України від 05.09.2017 p. № 2145-VIII. URL: http://zakon3.rada.gov.ua/laws/show/2145-19. (дата звернення: 28.01.2021).

14. Про затвердження Положення про вищі навчальні заклади МВС : наказ MBC України № 62 від 14.02.2008 p. URL: https://zakon.rada.gov.ua/laws/show/z019308/conv/print (дата звернення: 23.12.2020). 
15. Про вищу освіту : Закон України від 01.07.2014 p. № 1556-VII. URL: https://zakon.rada.gov.ua/laws/show/1556-18 (дата звернення: 28.01.2021).

16. Положення про систему внутрішнього забезпечення якості освіти Харківського національного університету внутрішніх справ. URL: http://univd.edu.ua/files/generaldocs/quality_education_KhNUVS.pdf (дата звернення: 24.12.2020).

17. Положення про систему внутрішнього забезпечення якості освіти Львівського державного університету внутрішніх справ. URL: http://www2.lvduvs.edu.ua/documents_pdf/normat_doc/norm_doc_lvduvs/polozh_pro_syste my_vnytr_zabezp.pdf (дата звернення: 18.12.2020).

18. Положення про систему внутрішнього забезпечення якості освіти Дніпропетровського державного університету внутрішніх справ. URL: https://dduvs.in.ua/wpcontent/uploads/files/nmc/polog/nakaz301.pdf (дата звернення: 20.12.2020).

19. Положення про систему внутрішнього забезпечення якості освіти Донецького юридичного інституту Міністерства внутрішніх справ України. URL: https://www.dli.donetsk.ua/education/education-reglament (дата звернення: 21.12.2020).

20. Положення про систему внутрішнього забезпечення якості освіти Одеського державного університету внутрішніх справ. URL: http://oduvs.edu.ua/wpcontent/uploads/2016/09/Polozhennya-pro-sistemu-vnutrishnogo-zabezpechennya-yakostivishhoyi-osviti-3.pdf (дата звернення: 10.12.2020).

21. Association of European Police Colleges. URL: https://www.aepc.net/missionstatement/ (дата звернення: 26.02.2021).

22. Association of European Police Colleges. URL: https://www.aepc.net/missionstatement/ (дата звернення: 26.02.2021).

23. European Union Agency for Law Enforcement Training. URL: https://www.cepol.europa.eu/who-we-are/european-union-agency-law-enforcementtraining/mission-vision-values (дата звернення: 15.02.2021).

24. International Association of Law Enforcement Leaders Standards and Training. URL: https://www.iadlest.org/about-us/about (дата звернення: 15.02.2021).

25. International Association of Chiefs of Police. URL: https://www.theiacp.org/aboutіаср (дата звернення: 23.02.2021).

26. International Police Association. URL: https://www.ipa-international.org/IPAStatutes (дата звернення: 14.02.2021).

\section{References}

1. Standarty i rekomendatsii shchodo zabezpechennia yakosti v Yevropeiskomu prostori vyshchoi osvity [Standards and recommendations for quality assurance in the European Higher Education Area]. Kyiv, 2015. 35 s. [in Ukrainian].

2. Tryma, K. (2020). Vplyv hromadskykh orhanizatsii na polityku yakosti vyshchoi osvity: analiz providnoho zarubizhnoho ta vitchyznianoho dosvidu [The influence of public organizations on the quality policy of higher education: an analysis of leading foreign and domestic experience]. Analiz providnoho vitchyznianoho ta zarubizhnoho dosvidu shchodo otsiniuvannia yakosti vyshchoi osvity $v$ umovakh yevrointehratsii: analitychni materialy u dvokh chastynakh. Kyiv. Ch. 1. S. 308-315 [in Ukrainian].

3. Pro hromadski obiednannia : Zakon Ukrainy vid 22.03.2012 r. № 4572-VI [About public associations : Law of Ukraine dated 22.03.2012]. URL: https://zakon.rada.gov.ua/laws/show/4572-17 (data zvernennia: 21.01.2021) [in Ukrainian].

4. Tryma, K. (2020). Vplyv hromadskykh orhanizatsii na polityku yakosti vyshchoi osvity: analiz providnoho zarubizhnoho ta vitchyznianoho dosvidu [The influence of public organizations on the quality policy of higher education: an analysis of leading foreign and domestic experience]. Analiz providnoho vitchyznianoho ta zarubizhnoho dosvidu shchodo otsiniuvannia 
yakosti vyshchoi osvity v umovakh yevrointehratsii: analitychni materialy u dvokh chastynakh. Kyiv. Ch. 2. S. 308-315 [in Ukrainian].

5. Review of the education sector of Ukraine: moving towards effectiveness, equity and efficiency. P. 77. URL: https://openknowledge.worldbank.org/handle/10986/32406 (data zvernennia: 27.03.2021).

6. OECD (2020), Education at a Glance 2020: OECD Indicators, OECD Publishing, Paris. URL: https://www.oecd-ilibrary.org/education/education-at-a-glance-2020_69096873-en (data zvernennia: 30.04.2021).

7. Analiz providnoho vitchyznianoho ta zarubizhnoho dosvidu humanizatsii vyshchoi osvity yak zasobu zabezpechennia yii yakosti: analitychni materialy (chastyna II) [Analysis of the leading domestic and foreign experience of humanization of higher education as a means of ensuring its quality: analytical materials (part II)] / za red. V. Luhovoho, Zh. Talanovoi. K. : IVO NAPN Ukrainy, 2016. 111 s. [in Ukrainian].

8. Rozvytok instytutsiinoho potentsialu universytetiv u konteksti hlobalnoho liderstva [Development of institutional capacity of universities in the context of global leadership]. Kyiv : Instytut vyshchoi osvity NAPN Ukrainy, 2017. 205 s. [in Ukrainian].

9. Tryma, K. (2018). Vplyv hromadskykh orhanizatsii na zabezpechennia yakosti vyshchoi osvity [The influence of public organizations on ensuring the quality of higher education]. Molodyi vchenyi. № 10. S. 107-114 [in Ukrainian].

10. Gilfillan B., Fee A. Shaping participation: an international NGO implementing a overnment participation policy. Development in Practice. 2017. 27:8. P. 1035-1049.

11. Natsionalnyi osvitnii hlosarii: vyshcha osvita [National Education Glossary: Higher Education]. K. : TOV «Vydavnychyi dim «Pleiady», 2011. 100 s. [in Ukrainian].

12. Pro vyshchu osvitu : Zakon Ukrainy vid 01.07.2014 r. № 1556-VII [About Higher Education : Law of Ukraine dated 01.07.2014]. URL: https://zakon.rada.gov.ua/laws/show/1556-18 (data zvernennia: 28.01.2021).

13. Pro osvitu : Zakon Ukrainy vid 05.09.2017 r. № 2145-VIII [About Education : Law of Ukraine dated 05.09.2017]. URL: http://zakon3.rada.gov.ua/laws/show/2145-19 (data zvernennia: 28.01.2021) [in Ukrainian].

14. Pro zatverdzhennia Polozhennia pro vyshchi navchalni zaklady MVS : nakaz MVS Ukrainy № 62 vid 14.02.2008 r. [On Approval of the Regulations on Higher Educational Institutions of the Ministry of Internal Affairs : Order of the Ministry of Internal Affairs of Ukraine No. 62 dated 14.02.2008]. URL: https://zakon.rada.gov.ua/laws/show/z0193-08/conv/print (data zvernennia: 23.12.2020) [in Ukrainian].

15. Pro vyshchu osvitu : Zakon Ukrainy vid 01.07.2014 r. № 1556-VII [About Higher Education : Law of Ukraine dated 01.07.2014]. URL: https://zakon.rada.gov.ua/laws/show/1556-18 (data zvernennia: 28.01.2021) [in Ukrainian].

16. Polozhennia pro systemu vnutrishnoho zabezpechennia yakosti osvity Kharkivskoho natsionalnoho universytetu vnutrishnikh sprav [Regulations on the system of internal quality assurance of education of Kharkiv National University of Internal Affairs]. URL: http://univd.edu.ua/files/generaldocs/quality_education_KhNUVS.pdf (data zvernennia: 24.12.2020) [in Ukrainian].

17. Polozhennia pro systemu vnutrishnoho zabezpechennia yakosti osvity Lvivskoho derzhavnoho universytetu vnutrishnikh sprav [Regulations on the system of domestic quality of education of the Lviv State University of Internal Affairs]. URL: http://www2.lvduvs.edu.ua/documents_pdf/normat_doc/norm_doc_lvduvs/polozh_p ro_systemy_vnytr_zabezp.pdf (data zvernennia: 18.12.2020). [in Ukrainian].

18. Polozhennia pro systemu vnutrishnoho zabezpechennia yakosti osvity Dnipropetrovskoho derzhavnoho universytetu vnutrishnikh sprav [Regulations on the system of internal quality assurance of education Dnipropetrovsk State University of Internal Affairs]. URL: https://dduvs.in.ua/wp-content/uploads/files/nmc/polog/nakaz301.pdf (data zvernennia: 20.12.2020) [in Ukrainian]. 
19. Polozhennia pro systemu vnutrishnoho zabezpechennia yakosti osvity Donetskoho yurydychnoho instytutu Ministerstva vnutrishnikh sprav Ukrainy. [Regulations on the system of internal quality assurance of education of the Donetsk Law Institute of the Ministry of Internal Affairs of Ukraine]. URL: https://www.dli.donetsk.ua/education/education-reglament (data zvernennia: 21.12.2020) [in Ukrainian].

20. Polozhennia pro systemu vnutrishnoho zabezpechennia yakosti osvity Odeskoho derzhavnoho universytetu vnutrishnikh sprav [Regulations on the system of domestic quality of education of the Odessa State University of Internal Affairs]. URL: http://oduvs.edu.ua/wpcontent/uploads/2016/09/Polozhennya-pro-sistemu-vnutrishnogo-zabezpechennya-yakostivishhoyi-osviti-3.pdf (data zvernennia: 10.12.2020) [in Ukrainian].

21. Association of European Police Colleges. URL: https://www.aepc.net/missionstatement/ (data zvernennia: 26.02.2021).

22. Association of European Police Colleges. URL: https://www.aepc.net/missionstatement/ (data zvernennia: 26.02.2021).

23. European Union Agency for Law Enforcement Training. URL: https://www.cepol.europa.eu/who-we-are/european-union-agency-law-enforcement-

training/mission-vision-values (data zvernennia: 15.02.2021).

24. International Association of Law Enforcement Leaders Standards and Training. URL: https://www.iadlest.org/about-us/about (data zvernennia: 15.02.2021).

25. International Association of Chiefs of Police. URL: https://www.theiacp.org/aboutiacp (data zvernennia: 23.02.2021).

26. International Police Association. URL: https://www.ipa-international.org/IPAStatutes (data zvernennia: 14.02.2021).

Salnikova Natalia,

$\mathrm{PhD}$ in History

(Donetsk State University of Internal Affairs, Mariupol)

ORCID: https://orcid.org/0000-0003-4931-0491

\section{ENSURING THE QUALITY OF EDUCATION IN HIGHER EDUCATION INSTITUTIONS : THE INFLUENCE OF INTERNATIONAL ORGANIZATIONS}

The development of the quality of higher education is a priority for the modern state policy of Ukraine. To implement the quality standards of higher education adopted in the European Higher Education Area, Ukrainian departmental universities are adapting the European experience, forming an internal quality assurance system. Departmental universities have been establishing an internal system of quality assurance since 2016. At this stage, the relevant provisions on the level of the universities have been developed to regulate the distribution of powers between different departments of the HEI. Another direction of quality assurance is cooperation with external stakeholders, in particular public organizations of various levels. Based on the analysis of examples of interaction between departmental higher education institutions of Ukraine and international non-governmental organizations available on the websites of relevant institutions, a conclusion was made about the discrete nature of cooperation and the lack of public information about the cooperation. According to information on the sites the universities and international NGOs cooperate in the form of joint public events of academic character, they organise training, conferences and round tables. International non-governmental organizations have great potential to ensure the quality of specialized higher education, in particular, in the joint development and revision of educational programs with universities, educational activities involving international experts, conducting international seminars and workshops, joint projects. Moreover, non-governmental organizations can provide educational services of non-formal education; to carry out projects addressed to local 
communities in partnership with higher education institutions. The author considers nongovernmental organizations to be an important mechanism for articulating public interests and requests of citizens and local communities which is critically important for the departmental universities. To realize this potential of cooperation, it is necessary to establish additional documents (regulations, concepts), which will detail the mechanism of cooperation between the departmental university and the non-governmental organization.

Key words: higher education; quality assurance; internal quality assurance; departmental universities; international organizations.

Надіслано до редколегії 05.05.2021

Рекомендовано до публікації 12.05.2021 
УДК: 378.147

DOI: https://doi.org/10.32366/2523-4269-2021-75-2-192-200

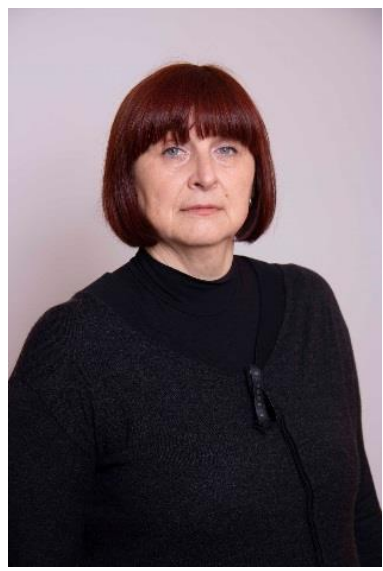

\section{Уткіна Галина Анатоліївна,}

кандидат економічних наук, доцент

(Донецький державний університет

внутрішніх справ, м. Кривий Ріг)

ORCID: http://orcid.org/0000-0001-7513-4407

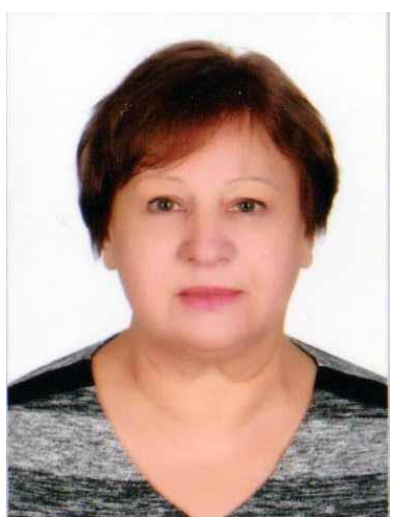

Дацюк Тетяна Кузьмівна,

кандидат історичних наук

(Донеиький державний університет

внутрішніх справ, м. Кривий Ріг)

ORCID: http://orcid.org/0000-0002-1708-076X

\section{ДЕЯКІ АСПЕКТИ РЕФОРМУВАННЯ ЮРИДИЧНОЇ ОСВІТИ В УКРАЇНI}

У статті проаналізовано сучасний стан реформування юридичної освіти в Україні. Розглянуто напрями та методи реформування вітчизняної системи правничої освіти з урахуванням вимог проєвропейського вектору розвитку вищої освіти України. Здійснено критичний аналіз деяких положень проєкту Концепції реформування юридичної освіти, оприлюдненого для громадського обговорення на сайті Міністерства освіти $i$ науки Украӥни. Зроблено висновок, що поступове переорієнтування вітчизняного ринку освітніх послуг на європейські стандарти якості зумовило реформування системи юридичної освіти відповідно до найкращих світових практик, але не варто забувати про власні традиції та побудову національного законодавства, нехтувати своїм потенціалом та досвідом побудови унікальних вітчизняних правничих шкіл.

Ключові слова: освітня політика держави; вища освіта; юридична освіта; правнича освіта; реформування.

Постановка проблеми. Юридична освіта є частиною системи спеціалізованої освіти, яка забезпечує підготовку юристів (правознавців) для роботи в державному апараті, судах, адвокатурі, народному господарстві, правоохоронних органах.

Розвиток вищої юридичної освіти в Україні бере свій початок від заснування юридичних факультетів у складі університетів, за винятком найдавнішого Львівського

(C) Уткіна Галина Анатоліївна,

Дацюк Тетяна Кузьмівна, 2021 
університету (1661), які з'явилися в ХІХ ст. у Харкові (1805), Києві (1835), Одесі (1865), Чернівцях (1875).

Сьогочасний стан вищої юридичної освіти має суперечливі характеристики, кількість закладів вищої освіти (далі - ЗВО), які надають правничу освіту в Україні, сягає майже 300 закладів, тоді як до 1991 року їх було лише 6. Для порівняння: у Польщі таких ЗВО налічується 25 (з них 10 приватні), у Німеччині - 42 (один приватний), у Франції - 80, у Великій Британії - 97, у Сполучених Штатах Америки - менше 200. Необхідно зазначити, що юридична освіта не є винятком, така тенденція характерна для всього сектора вищої освіти в Україні: нині у Великій Британії існує близько 100 університетів, у Франції - близько 80, в Італії - близько 60, у Польщі - 11, а в Україні- 904 [7].

Поступове переорієнтування українського ринку надання освітніх послуг на європейські стандарти діяльності вимагає реформування системи основних принципів надання юридичної освіти.

Аналіз останніх досліджень і публікацій. Сучасним проблемам реформування української системи освіти приділялася увага в працях відомих фахівців, серед яких роботи професора, члена Національної команди експертів з реформування вищої освіти Володимира Бахрушина, першого заступника директора ДНУ «Інститут освітньої аналітики» Оксани Денисюк, провідного лектора Києво-Могилянської академії Оксани Кирієнко, кандидата економічних наук, доцента Київського національного університету імені Тараса Шевченка Максима Ситницького, наукового співробітника відділу статистики та аналітики вищої освіти ДНУ «Інститут освітньої аналітики» Оксани Чумак та багато інших. Питання реформування юридичної освіти були висвітлені в роботах провідних теоретиків у сфері освіти та практиків, зокрема, їх вивчали: Ірина Єфремова (Голова Наглядової ради Харківського національного університету внутрішніх справ, кандидат юридичних наук, доцент), Роман Шандра (доцент Львівського національного університету імені Івана Франка), Юлія Гришина (народний депутат України від політичної партії «Слуга народу», голова підкомітету з питань вищої освіти Комітету Верховної Ради з питань освіти, науки та інновацій) та інші. Проте аналіз джерельної бази та сучасні тенденції реформування системи вищої юридичної освіти в Україні вказують на недостатній рівень розробленості теми, що обумовлює ії актуальність.

Метою цієї статті $\epsilon$ аналіз стану реформування юридичної освіти в Україні та виокремлення найбільш дискусійних аспектів цього процесу.

Виклад основного матеріалу. Незважаючи на те, що термін «вища юридична освіта» широко використовується в Конституції України та законодавстві, його зміст залишається невизначеним і в різних законах тлумачиться по-різному. Переважно вищу юридичну освіту розуміють як вищу освіту магістерського рівня за спеціальностями 081 «Право» та 293 «Міжнародне право». На думку В. Бахрушина, недоцільно тлумачити поняття вищої юридичної освіти за назвами спеціальностей. Більш обгрунтованим і відповідним до практики провідних держав було б визначення: вищою юридичною освітою (на підставі норм Конституції та законів, що містять це поняття) є вища освіта, здобута за певними освітніми програмами, які під час акредитації визнані такими, що надають освіту, яка відповідає кваліфікаційним вимогам до обіймання певних посад. При цьому можуть бути передбачені особливі умови акредитації таких програм, зокрема врахування результатів єдиного державного іспиту та залучення до оцінювання програм представників професійного співтовариства [3].

На сьогодні юридична освіта має високий рейтинг на ринку освітніх послуг та розглядається абітурієнтом як запорука отримання престижних високооплачуваних професій та можливостей для роботи у сфері державного управління, судочинства та правоохоронних органах, набуття таких професій, як суддя, адвокат, прокурор. Таке ставлення спричиняє підвищений попит на ці професії, а відповідно і створює феномен множення спеціальностей юридичного спрямування в непрофільних ЗВО (рис.1). До 1991 р. правників в Україні готували 6 закладів (усі державні), 1995 р. - 96 (65 - державної і 31 - інших форм власності), 2000 р. - 163 (відповідно 116 і 47), 2002-2003 pp. - 189 (134; 55) [10]. 


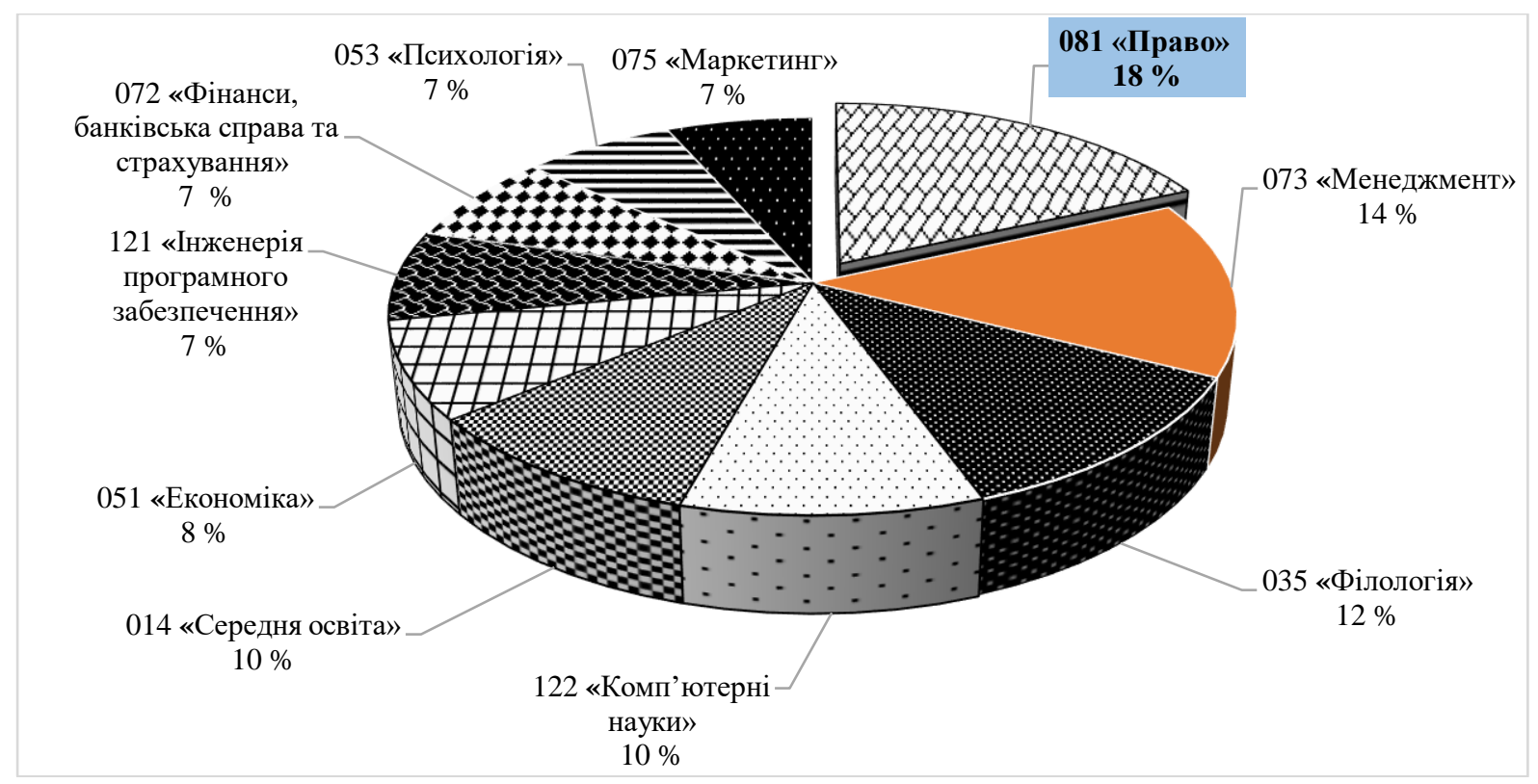

Рис. 1. Десять найбільш популярних спеціальностей за кількістю поданих заяв під час вступної кампанії 2020 року

Однак правові спеціальності потребують неабияких зусиль від здобувача, зокрема уважності, знання Конституції України й чинного законодавства, методів криміналістики, психології, цивільного, трудового, кримінального, фінансового, адміністративного права, основ економіки, організації праці, управління і виробництва, уміння використовувати комп'ютерну техніку на рівні досвідченого користувача тощо. Важливими для юриста є такі якості: відповідальність, розвинене логічне мислення, ініціативність, наполегливість, старанність, емоційна стійкість. Випускник будь-якого юридичного фаху потребує напрацювання досвіду та визначення власної спеціалізації для подальшої роботи. Ці труднощі не стають перешкодою для абітурієнтів, чисельність яких збільшується, як наслідок упродовж останніх років відбувається зростання кількості ЗВО, які надають відповідні освітні послуги, передусім на контрактній основі. Багато фахівців уважають, що саме комерціалізація юридичної освіти стала наслідком падіння іiї якості, тому що більшість непрофільних 3ВО відкривали юридичні факультети без належного кадрового забезпечення.

Серед ЗВО, які нині здійснюють підготовку юристів в Україні, є:

1) класичні вузи - це, зокрема, Київський національний університет імені Тараса Шевченка, Львівський національний університет імені Івана Франка, Національний університет «Києво-Могилянська академія», Одеський національний університет імені I. I. Мечникова, Донецький національний університет (м. Вінниця), Дніпропетровський національний університет імені Олеся Гончара, Східноукраїнський національний університет імені Володимира Даля, Харківський національний університет імені В. Н. Каразіна, Запорізький національний університет, Сумський державний університет, Ужгородський національний університет, Східноєвропейський національний університет імені Лесі Українки, Херсонський державний університет, Чернівецький національний університет імені Юрія Федьковича, Закарпатський державний університет та ін.;

2) профільні юридичні вузи - це, наприклад, Одеська національна юридична академія, Національний юридичний університет імені Ярослава Мудрого, Академія адвокатури України, Київський університет права Національної академії наук України, Дніпропетровський державний університет внутрішніх справ, Донецький юридичний інститут Міністерства внутрішніх справ України (нині - Донецький державний університет внутрішніх справ). Крім того, готують правознавців і такі 3ВО, як Львівський державний університет 
внутрішніх справ, Харківський національний університет внутрішніх справ, Луганський державний університет внутрішніх справ імені Е. О. Дідоренка, Національна академія Служби безпеки України, Одеський державний університет внутрішніх справ, Харківський національний університет внутрішніх справ та ін.;

3) непрофільні вузи - технічні, економічні, педагогічні, транспортні та ін. Варто зазначити, що 3-поміж 3ВО, які нині випускають юристів, значну частину становлять так звані непрофільні та інші вузи [5].

За регіонами розподіл загального ліцензійного обсягу за спеціальністю «Право» показано на рис. 2.

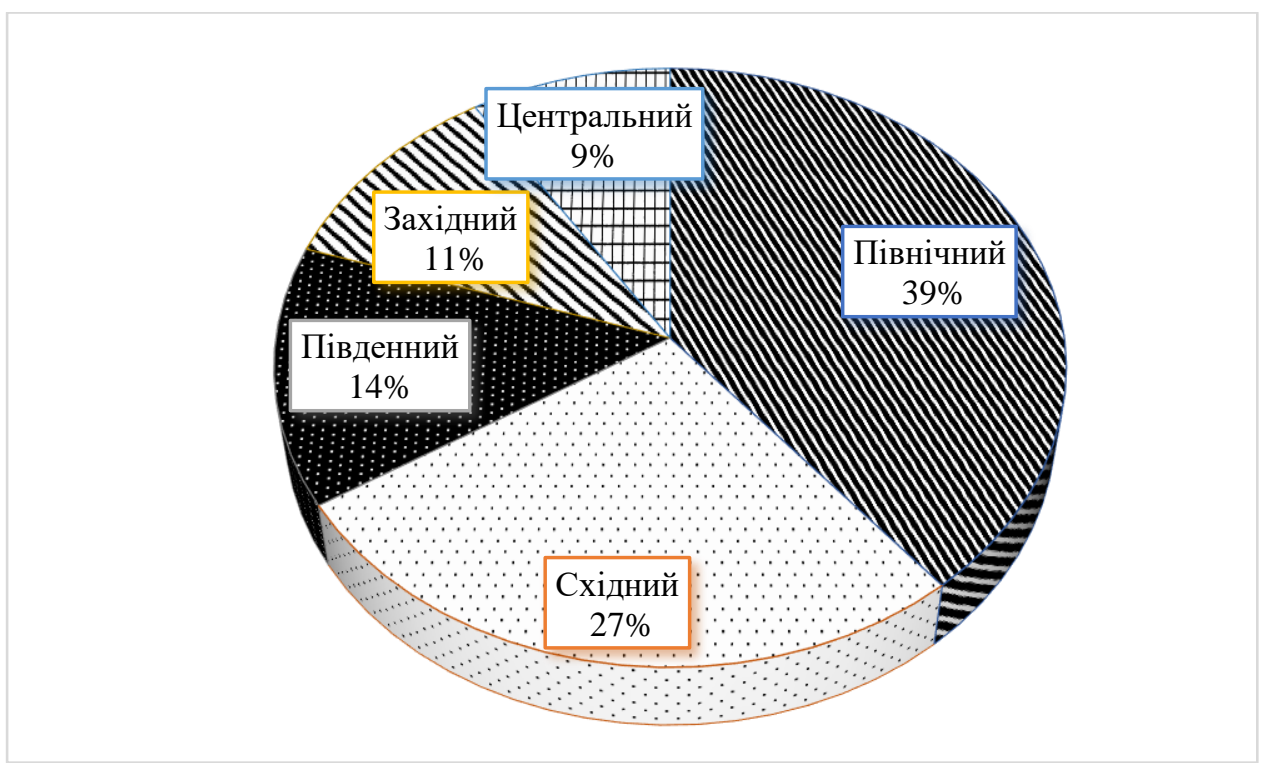

Рис. 2. Розподіл ліцензійного обсягу за регіонами України за спеціальністю «Право» станом на 2020 рік

3 метою вирішення проблем якості юридичної освіти та збалансування попиту на ринку освітніх послуг Міністерством освіти і науки України (далі - МОН України) було прийнято низку новацій, а саме: збільшено прохідний бал (за умовами 3ВО у 2020 році мінімальний прохідний бал на бюджетну форму навчання за спеціальністю «Право» був визначений 150 , що на 25 балів вище ніж на інші спеціальності), зменшено ліцензований обсяг відповідних спеціальностей, розроблено проєкт Концепції розвитку юридичної освіти.

Ще одним механізмом регулювання попиту та створення рівних умов на ринку освітніх послуг стало впровадження індикативної вартості навчання. Згідно з Постановою Кабінету Міністрів України № 191 від 03.03.2020 року «Деякі питання запровадження індикативної собівартості» (далі - Постанова) було розпочато поступове досягнення цінового паритету між вартістю, що сплачує держава за навчання 1 здобувача вищої освіти, та вартістю навчання за контрактом, що сплачує здобувач вищої освіти за встановленими ЗВО цінами. Індикативна вартість була застосована для 121 спеціальності у 160 закладах вищої освіти, що підпорядковані МОН України, у тому числі для спеціальності «Право». Відповідно до Постанови здійснюється поступове вирівнювання та фіксація вартості освітніх послуг 3 унеможливленням здешевлення. Так, у 2020 році вона становить $60 \%$ від держфінансування на 1 здобувача вищої освіти в університеті, у 2021 році буде складати $70 \%$, у 2022 році-80\%.

Ексзаступник міністра освіти і науки Сгор Стадний (2019-2020 рр.) зазначив: «Справедлива ціна на контракти дозволить підвищити якість освіти. Більше грошей - це можливість університетам інвестувати в лабораторії, а також платити вищу зарплату кращим викладачам. Водночас установлення індикативної собівартості на популярні спеціальності 
дозволить мотивувати вступників йти на менш популярні програми, наприклад інженерні. Вони затребувані на ринку праці» [11].

Зі зростанням вартості освітніх послуг здійснюється також і зменшення ліцензійних обсягів на спеціальність «Право»: за період 2017-2020 рр. відбулося зменшення на 1,2 \%.

Запропонована Концепція розвитку юридичної освіти (далі - Концепція) має низку суперечливих та дискусійних положень. Найбільш радикальним убачаємо новий зміст правничого фаху стосовно поділу юридичних професій на категорії. До першої категорії належать «регульовані види правничої діяльності» (суддя, прокурор, адвокат). У другу групу автоматично потрапляють усі інші напрями правничого фаху, а саме: робота на посаді нотаріуса, юридичного радника, слідчого; керівників юридичних служб державних органів, підприємств, установ. Третій напрям становить підготовка наукових кадрів вищої категорії. Основною метою поділу правничих професій на групи є підвищення якості підготовки фахівців, які по закінченню юридичного ЗВО будуть практикувати у сфері регулювання правничої діяльності та зможуть реалізовуватися за обраною спеціальністю.

3 огляду на такий поділ виникає проблема відомчої освіти. ЗВО зі спеціальними умовами навчання забезпечують підготовку фахівців за вузькими спеціалізаціями в межах галузі знань «Право» та «Правоохоронна діяльність». Серед них 3ВО, що функціонують у системі Міністерства внутрішніх справ України (далі - МВС України), Служби безпеки України, Державної фіскальної служби, Державної пенітенціарної служби України.

У контексті запропонованої Концепції відбувається дискусія: чи достатньо майбутнім поліцейським професійної освіти, чи на посадах середнього та старшого офіцерського складу органів поліції повинні працювати юристи з вищою освітою? Проблеми фахової підготовки рядового й офіцерського складу МВС України активно обговорюються у зв'язку зі створенням у 2015 році Національної поліції. На тлі цих дискусій з'явилися досить радикальні бачення реформування ЗВО зі специфічними умовами навчання в системі МВС України. Так, Асоціація українських моніторів дотримання прав людини в діяльності правоохоронних органів пропонує ліквідацію всіх ЗВО в системі МВС України та створення на базі ліквідованих ЗВО мережі поліцейських шкіл, які не надають вищу освіту, а здійснюють первинну підготовку поліцейських (від шести місяців до одного року) як для тих посад в поліції, де не потрібна вища юридична освіта, так і для тих, де необхідна юридична освіта, а також проводять регулярні заходи з підвищення кваліфікації для всіх поліцейських [6].

Член Вищої ради правосуддя, професор, доктор юридичних наук Андрій Бойко переконаний, що фах правника наділений професійною незалежністю та відповідальністю і не може здобуватися в закладах, де все будується на підпорядкуванні вищому за званням та субординації: «Правник є носієм верховенства права. Він служить суспільству, у нього інша місія. Він повинен навчатися там, де гарантуються академічні права та свободи. Цього не може бути в подібних закладах» [9]. Однак він погоджується з тим, щоб у таких вишах створювалися потужні правничі школи, і не варто необдумано знищувати все [9].

Отже, у Концепції пропонується, що «...готувати юристів зможуть тільки юридичні школи («правничі»), що перебувають у підпорядкуванні $\mathrm{MOH}$ України (класичні університети, профільні університети), і приватні вищі учбові заклади, що отримали ліцензію, а відомчі вузи в цьому законопроєкті взагалі не розглядаються i, вочевидь, на переконання його авторів, мають взагалі зникнути... Автори проєкту мали б знати, що нині найбільшим роботодавцем і так званим споживачем юридичних кадрів є саме Міністерство внутрішніх справ. Цікаво й те, що юридичними професіями в цьому законопроєкті визнаються лише такі, як суддя, адвокат, прокурор та нотаріус, і рівень їхньої освіти має відповідати рівню кваліфікації магістра права. Щодо юридичної професії, то оперативні працівники, слідчі, юрисконсульти підприємств - це вже не юристи, і обіймати ці посади можуть будь-які спеціалісти 3 будь-якою освітою», - наголошує у своій статті Сергій Гусаров, доктор юридичних наук, професор, член-кореспондент Національної академії правових наук України, академік Інженерної академії України, заслужений юрист України [4]. 
Досить часто науковці порівнюють вітчизняну юриспруденцію 3 механізмами отримання вищої юридичної освіти таких держав, як Німеччина, Англія, США. Виникає питання доречності та можливості перенесення цих схем на реалії освіти України загалом. Зараз інститути зі специфічними умовами навчання є потужними конгломератами, що об'єднують не тільки спеціальності поліцейського спрямування, а й професії за спеціальностями 081 «Право», 262 «Правоохоронна діяльність», 051 «Економіка» (спеціалізація - економічна безпека), 21.05 «Інформаційна безпека держави» та інші, які надаються в межах контрактної форми навчання тим, хто виявив бажання отримати цей фах. Згідно зі статистичними даними прийому студентів до ЗВО за джерелами фінансування станом на 2018 рік заклади, що знаходяться у підпорядкуванні МВС України, за контрактною формою здійснюють підготовку 52 \% від загального обсягу слухачів. Необхідно наголосити, що всі абітурієнти, незважаючи на форму фінансування, добровільно та цілеспрямовано обрали саме ці заклади вищої освіти для отримання освіти. Отже, розгляд ЗВО зі специфічними умовами навчання як закладів, «де все будується (освітній процес) на покорі перед вищим за званням та субординації» [9], є обмежений і такий, що призводить до порушення принципу вільного доступу до освіти та надає саме цим закладам дискримінаційного статусу, незважаючи на потужний викладацький склад, який забезпечує високий рівень викладання.

Традиційною залишається ступенева освіта для здобуття доступу до інших видів правничої діяльності. Спочатку навчання за освітньо-професійною програмою бакалавра, потім проходження єдиного державного кваліфікаційного іспиту (далі - СДКІ) - вступ до магістратури зі складанням єдиного вступного іспиту з іноземної мови та єдиного фахового вступного випробування. Після закінчення навчання в магістратурі також складається СДКІ, за результатами якого випускник отримує кваліфікацію «магістр» за спеціальністю «Право / міжнародне право» з обов'язковим зазначенням спеціалізації. Проте необхідно зауважити, що сьогодні активно відбувається обговорення питання впровадження принципу наскрізної магістратури.

Висновки. Підсумовуючи, можна зробити висновок, що юридична освіта є складовою вищої освіти України та відповідає запитам суспільства. Сучасна державна політика України має проєвропейський вектор розвитку. Поступове переорієнтування вітчизняного ринку освітніх послуг на європейські стандарти якості зумовило реформування системи юридичної освіти відповідно до найкращих світових практик, але не варто забувати про свої традиції та формування національного законодавства, нехтувати власним потенціалом та досвідом побудови унікальних вітчизняних правничих шкіл.

Водночас необхідно наголосити, що реформа юридичної освіти $\epsilon$ на сьогодні актуальною та необхідною для забезпечення змін у всій правовій системі держави з метою створення потужного апарату захисту державницьких інтересів, прав і свобод кожного громадянина України.

\section{Список використаних джерел}

1. Проєкт Закону про юридичну (правничу) освіту і загальний доступ до правничої професіï. URL: http://w1.c1.rada.gov.ua/pls/zweb2/webproc4_1?pf3511=62613 (дата звернення: 10.05.2021).

2. Проєкт Концепції реформування юридичної освіти. URL: https://mon.gov.ua/ua/ news/mon-proponuye-dlya-gromadskogo-obgovorennya-napracovanij-spilno-zministerstvomyusticiyi-ukrayini-proekt-koncepciyi-reformuvannya (дата звернення: 10.05.2021).

3. Бахрушин В. Що можна вважати вищою юридичною освітою. URL: http://education-ua.org/ua/articles/897-shcho-mozhna-vvazhati-vishchoyu-yuridichnoyu-osvitoyu (дата звернення: 10.05.2021). 
4. Гусаров С. М. MBC без юристів - кому це вигідно? URL: http://www.golos.com.ua/article/294627 (дата звернення: 10.05.2021).

5. Опришко В. Ф. Особливості підготовки юристів у непрофільних вищих навчальних закладах України: сучасний стан i шляхи подальшого розвитку. Правове регулювання економіки. 2013. Вип. 13. C. 6-27. URL: http://nbuv.gov.ua/UJRN/pre_2013_13_3 (дата звернення: 10.05.2021).

6. Реформувати систему поліцейської освіти. URL: http://umdpl.info/policeexperts.info/legislation/education/ (дата звернення: 10.05.2021).

7. Стан юридичної освіти та науки в Україні (результати досліджень) / ОБСЄ. URL: http://www.osce.org/ uk/ukraine/108309?download=true (дата звернення: 10.05.2021).

8. Чумак О. В. Модернізація державного механізму фінансування вищої освіти в умовах їі реформування. Теорія та практика держсавного управління : збірник наукових праџь ХарРІ НАДУ. 2017. № 3. С. 56-72.

9. Якуша В. Запасний аеродром. Закон $i$ бізнес. 2021. № 7 (1513). URL: https://zib.com.ua/ua/print/146684-

mvs_uchat_lishe_koritisya_tomu_pravnikiv_u_pogonah_bilshe_html (дата звернення: 10.05.2021).

10. Вища юридична освіта в Україні. Проблема розвитку та вдосконалення. URL: https://bookster.com.ua/vyshcha-iurydychna-osvita-v-ukraini-problema-rozvytku-tavdoskonalennia/ (дата звернення: 10.05.2021).

11. Вартість контрактного навчання має відповідати фактичним витратам університету - уряд ухвалив постанову про індикативну собівартість. URL: https://mon.gov.ua/ua/news/vartist-kontraktnogo-navchannya-maye-vidpovidati-faktichnimvitratam-universitetu-uryad-uhvaliv-postanovu-pro-indikativnu-sobivartist (дата звернення: 10.05.2021).

\section{References}

1. Proekt Zakonu pro yurydychnu (pravnychu) osvitu i zahalnyi dostup do pravnychoi profesii [Draft law on legal education and general access to the legal profession]. URL: http://w1.c1.rada.gov.ua/pls/zweb2/webproc4_1?pf3511=62613[in Ukrainian].

2. Proekt Kontseptsii reformuvannia yurydychnoi osvity [Draft Concept of Legal Education Reform]. URL: https://mon.gov.ua/ua/ news/mon-proponuye-dlya-gromadskogoobgovorennya-napracovanij-spilno-zministerstvom-yusticiyi-ukrayini-proekt-koncepciyireformuvannya [in Ukrainian].

3. Bakhrushyn, V. (2017). Shcho mozhna vvazhaty vyshchoiu yurydychnoiu osvitoiu [What can be considered higher legal education]. URL: http://education-ua.org/ua/articles/897shcho-mozhna-vvazhati-vishchoyu-yuridichnoyu-osvitoyu (data zvernennia: 10.05.2021) [in Ukrainian].

4. Husarov, S. M. (2017). MVS bez yurystiv - komu tse vyhidno? [The Ministry of Internal Affairs without lawyers _ who benefits from it?]. URL: http://www.golos.com.ua/article/294627 [in Ukrainian].

5. Opryshko, V.F. (2013). Osoblyvosti pidhotovky yurystiv u neprofilnykh vyshchykh navchalnykh zakladakh Ukrainy: suchasnyi stan i shliakhy podalshoho rozvytku [Features of training of lawyers in non-core higher educational institutions of Ukraine: current state and ways of further development]. Pravove rehuliuvannia ekonomiky. № 13. S. 6-27. URL: http://nbuv.gov.ua/UJRN/pre_2013_13_3 (data zvernennia: 10.05.2021) [in Ukrainian].

6. Reform the police education system [Reform the police education system]. URL: http://umdpl.info/police-experts.info/legislation/education [in Ukrainian]. 
7. Stan yurydychnoi osvity ta nauky v Ukraini (rezultaty doslidzhen) / OBSIe [The state of legal education and science in Ukraine (research results) / OSCE]. URL: http://www.osce.org/uk/ukraine/108309?download=true [in Ukrainian].

8. Chumak, O. V. (2017). Modernizatsiia derzhavnoho mekhanizmu finansuvannia vyshchoi osvity $\mathrm{v}$ umovakh yii reformuvannia [Modernization of the state mechanism of financing higher education in the conditions of its reform]. Teoriia ta praktyka derzhavnoho upravlinnia: zbirnyk naukovykh prats KharRI NADU. № 3. S. 56-72 [in Ukrainian].

9. Iakusha, V. (2021). Zapasnyi aerodrom [Spare airfield]. Zakon i biznes. № 7 (1533). URL: https://zib.com.ua/ua/print/146684_mvs_uchat_lishe_koritisya_tomu_pravnikiv_u_pogonah_ bilshe_.html (data zvernennia: 10.05.2021) [in Ukrainian].

10. Vyshcha yurydychna osvita v Ukraini. Problema rozvytku ta vdoskonalennia [Higher legal education in Ukraine. The problem of development and improvement]. URL: https://bookster.com.ua/vyshcha-iurydychna-osvita-v-ukraini-problema-rozvytku-ta-vdoskonalennia (data zvernennia: 10.05.2021) [in Ukrainian].

11. Vartist kontraktnoho navchannia maie vidpovidaty faktychnym vytratam universytetu - uriad ukhvalyv postanovu pro indykatyvnu sobivartist [The cost of contract tuition should correspond to the actual costs of the university - the government has adopted a resolution on the indicative cost]. URL: https://mon.gov.ua/ua/news/vartist-kontraktnogo-navchannya-mayevidpovidati-faktichnim-vitratam-universitetu-uryad-uhvaliv-postanovu-pro-indikativnu-sobivartist (data zvernennia: 10.05.2021) [in Ukrainian].

\title{
Utkina Galina,
}

$\mathrm{PhD}$ in Economics

(Donetsk State University of Internal Affairs, Kryvyi Rih)

ORCID: http://orcid.org/0000-0001-7513-4407

\author{
Datsiuk Tetiana, \\ $\mathrm{PhD}$ in History \\ (Donetsk State University of Internal Affairs, Kryvyi Rih) \\ ORCID: http://orcid.org/0000-0002-1708-076X
}

\section{SOME ASPECTS OF THE LEGAL EDUCATION REFORM IN UKRAINE}

The article analyzes the current state of the legal education reform in Ukraine. It also considers the directions and methods of reforming of the domestic system of legal education, which takes into account the requirements of the pro-European vector of development of higher education in Ukraine. The article reviews the work of leading theorists and practitioners on reforming higher legal education. It also considers different points of view and the author expresses personal point of view of the problem. Analysis of the source base and current trends in reforming the system of higher legal education in Ukraine indicates an insufficient level of development of the topic, which determines its relevance. The Ministry of Education and Science of Ukraine acts as a regulator of the education market and takes a number of measures to optimize it. Thus, a draft Concept of Legal Education Reform for legal education has been developed. A critical analysis of some of the project's provisions revealed contradictory provisions that could negatively affect the state of legal education in Ukraine. The authors emphasize that in Ukraine, free educational institutions with specific training conditions, in particular those that are in the system of Interior Ministry of Ukraine, should continue to coexist with classical legal institutions of higher education. These institutions have already become powerful educational conglomerates for the training applicants for higher education for their further employment in the police, as well as in public and private institutions in various specialties - 
economic security, information security, management. The article also focuses on the inappropriateness of the full transfering of the educational experience of economically powerful countries to Ukraine. It has led to a conclusion that the gradual reorientation of the domestic market to European quality standards gave impetus to reform of the legal education system to the best world practices, but our traditions, national legislation, potential and experience in building unique domestic law schools should not be forgotten or neglected.

Key words: state educational policy; higher education; legal education; reforming.

Надіслано до редколегії 17.05.2021

Рекомендовано до публікації 21.05.2021 


\section{РОЗДІЛ VI \\ АКТУАЛЬНІ ПИТАННЯ ПОЛЦЕЙСЬКОЇ ДІЯЛЬНОСТІ \\ ТА ПІДГОТОВКИ КАДРІВ ДЛЯ ПІДРОЗДІЛІВ \\ НАЦІОНАЛЬНОЇ ПОЛІЦЇ̈ УКРАЇНИ}

УДК: 342.951:351.74(477)

DOI: https://doi.org/10.32366/2523-4269-2021-75-2-201-210

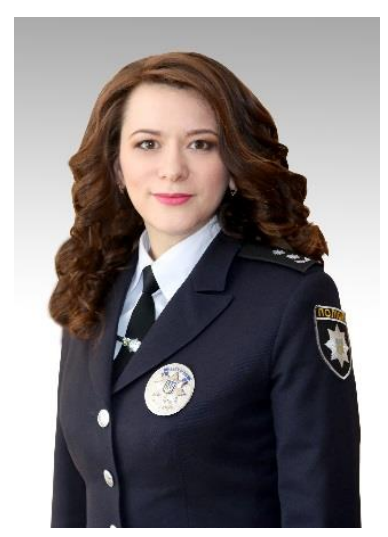

Мердова Ольга Миколаївна, кандидат юридичних наук, доцент (Донецький державний університет внутрішніх справ, м. Маріуполь) ORCID: https://orcid.org/0000-0003-0769-2364

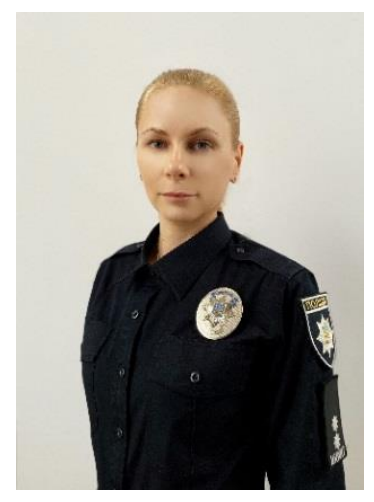

Філіпенко Анастасія Юріївна, здобувач освітнього ступеня «магістр» (Донецький державний університет внутрішніх справ, м. Маріуполь) ORCID: https://orcid.org/0000-0003-2370-2497

\section{МЕТОДИ ОЦІНЮВАННЯ ЕФЕКТИВНОСТІ ПОЛІЦЕЙСЬКОЇ ДІЯЛЬНОСТІ}

У статті проаналізовано наявні методи оцінювання ефективності полічейської діяльності. Доведено, щцо сучасна система методів оцінювання ефективності поліцейської діяльності повинна складатися з традииійних методів, характерних для діяльності поліиії, та нетрадиційних, запроваджених з інших сфер. Зроблено висновок про те, щзо на сьогодні актуальним питанням $\epsilon$ застосування під час оцінки ефективності поліцейської діяльності методів (методик), що використовуються в недержавному секторі для оиінювання ефективності діяльності різних установ, підприємств, організацій, а також методи оцінки персоналу, щуо вдало апробовані та реалізуються в управлінні, недержавних структурах, які є достатньо різноманітними.

Ключові слова: полічія; полічейська діяльність; оцінювання ефективності; методи оцінювання.

Постановка проблеми. Тривалий час у нашій країні існувала так звана «палочна» система оцінювання ефективності діяльності підрозділів міліції (нині - поліції), яка довела

(C) Мердова Ольга Миколаївна,

Філіпенко Анастасія Юріївна, 2021 
свою недієвість. Після реформування зазначеного правоохоронного органу та створення замість нього Національної поліції України одночасно було проголошено нові підходи щодо оцінювання ефективності поліцейської діяльності. У їі основу покладено оцінку рівня довіри населення до поліції, проте, як засвідчив аналіз правозастосовної практики, разом із новим підходом у відомчій системі оцінювання поліцейської діяльності збереглися певні елементи кількісного оцінювання поряд із запровадженими новими методами.

На сьогодні оцінювання ефективності діяльності поліції є необхідним інструментом процесу управління. Система оцінки дозволяє визначати пріоритети, формулювати актуальні завдання та напрями корекції поліцейської діяльності, зрештою забезпечувати ефективність роботи поліції. Одним із актуальних питань цього процесу є аналіз і переосмислення сучасної системи методів оцінювання ефективності поліцейської діяльності, основу якої повинні становити нові прогресивні методи (методики), що можуть бути запроваджені з інших сфер публічного адміністрування, менеджменту тощо, що обумовлює необхідність наукових досліджень у цій галузі з виробленням науково обгрунтованих підходів.

Аналіз останніх досліджень та публікацій. Дослідженню питань оцінювання ефективності діяльності органів Національної поліції та їх посадових осіб присвячено чималу кількість наукових праць, серед яких роботи таких учених, як К. Л. Бугайчук, В. Г. Залужний, Є. О. Крапивін, Д. М. Ластосвич, О. А. Лупало, А. М. Сердюк, І. О. Святокум, В. В. Чумак та інших, однак питання щодо методів оцінювання зазначеної діяльності висвітлено в них фрагментарно.

Формування цілей статті (постановка завдання). Мета статті полягає у здійсненні комплексного аналізу наявних методів оцінювання ефективності поліцейської діяльності, їхньої дієвості та визначення можливості розширення їхньої системи.

Виклад основного матеріалу. За своєю суттю оцінювання ефективності поліцейської діяльності $\epsilon$ своєрідним дослідженням, яке передбачає застосування певних методів. Загальновідомо, що метод - це сукупність прийомів і способів, за допомогою яких здійснюється який-небудь процес. Це цілком стосується й оцінювання ефективності поліцейської діяльності. Методами оцінювання ефективності поліцейської діяльності $\epsilon$ сукупність прийомів і способів, завдяки яким воно здійснюється.

На сьогодні в положеннях чинних нормативно-правових актів використання відсутня пряма вказівка на застосування певних методів оцінювання ефективності поліцейської діяльності. Що ж стосується наукових поглядів учених, то вони характеризуються плюралізмом позицій щодо системи методів оцінювання ефективності поліцейської діяльності.

Так, деякі вчені зазначають, що методи оцінювання ефективності діяльності поліції, що застосовуються сьогодні на практиці, умовно слід поділити на три групи:

1) методи якісної оцінки (описовий метод), які пов'язані з вивченням та узагальненням інформації про діяльність підрозділів та посадових осіб, їх найбільш важливих досягнень та недоліків у роботі;

2) методи кількісних показників, що передбачають накопичення та узагальнення тільки даних оперативної статистики - відсоток розкриття злочинів, показники, які характеризують якість профілактичної роботи, продуктивність праці, стан злочинності та охорони громадського порядку на території обслуговування тощо. Ця оцінка вимірюється кількісними (цифровими) показниками: балами, коефіцієнтами;

3) комбіновані методи, які полягають у використанні обох згаданих методів одночасно. Це сумарні оцінки, результати тестування та опитування, анкетування [1, с. 116; 2 , c. 191].

На нашу думку, такі методи властиві тільки відомчому оцінюванню ефективності поліцейської діяльності. У свою чергу, громадському оцінюванню переважно притаманні методи, що застосовуються в соціології.

О. В. Батраченко до методів оцінювання ефективності забезпечення Національною поліцією публічної безпеки і порядку відносить: 
1) моніторинг звітів щодо діяльності поліції у відповідній сфері;

2) проведення атестування поліцейських, у тому числі тих, які займають керівні посади;

3) здійснення опитування серед співробітників поліцейських органів шляхом анкетування для визначення проблем та недоліків організації роботи в підрозділах, оцінки методів керівництва, визначення клімату в робочому колективі;

4) проведення анкетування користувачів поліцейських послуг (заявників, потерпілих від правопорушень, правопорушників тощо) 3 метою визначення якісних характеристик діяльності поліції та іїі окремих підрозділів;

5) вивчення громадської думки, рівня довіри населення (соціологічні дослідження) $[3$, c. 62].

3 огляду на це цілком правильною та аргументованою вважаємо позицію В. Г. Залужного, який зазначає, що залежно від виду оцінювання службової діяльності поліцейських законодавчо обгрунтованим є виокремлення двох груп методів. Першу групу становлять методи, які застосовуються під час оцінювання поліцейських громадськістю і які використовуються для отримання інформації про оцінку населенням: якості виконання органами і підрозділами Національної поліції покладених на них завдань і функцій; відповідності роботи поліцейських очікуванням населення; виявлення тенденцій зміни рівня довіри та факторів, що на них впливають (спостереження, опитування, вільна коефіцієнтна оцінка). До другої групи належать методи, що застосовуються під час відомчого оцінювання: якісні - співбесіда, моніторинг, описовий, аналіз конкретних ситуацій, документальний; кількісні - стандартні оцінки, задана бальна шкала, матричний, градації; комбіновані тестування, сумарних оцінок [4, с. 12]. Однак назвати таку класифікацію вичерпною убачається передчасним, адже на сьогоднішній день відомі й інші методи оцінювання ефективності діяльності поліції. Проаналізуємо їх докладніше.

Наприклад, здійснюючи щорічне узагальнене оцінювання територіальних служб поліції, у Великобританії застосовують методику PEEL. Відповідно до неї оцінюються три базові показники діяльності поліції:

1) ефективність - відповідно до цього показника оцінюється, наскільки повно територіальна поліцейська служба виконує поставлені перед нею завдання;

2) доцільність - за цим показником з'ясовується, наскільки ефективно територіальна поліцейська служба використовує наявні в неї ресурси. Під час оцінки згаданого напряму визначається ефективність управління ресурсами, наявними у службі, доцільність планування та здійснення фінансової діяльності тощо;

3) легітимність - згідно з цим показником можна охарактеризувати ступінь довіри населення до поліцейського підрозділу. За цим напрямом оцінюється робота підрозділу із забезпечення дотримання його працівниками норм професійної етики, а також стан взаємодії підрозділу з населенням, ступінь довіри до нього [5, с. 26].

Останнім часом більш активно обговорюється питання доцільності застосування під час оцінки ефективності діяльності органів державної влади методів (методик), що використовуються в недержавному секторі для оцінювання ефективності діяльності різних установ, підприємств, організацій.

Протягом останніх 20 років з'явилося багато різних методів оцінки й удосконалення діяльності органів влади, як правило, запозичених із практики приватного сектора. Зокрема, це такі технології, як бенчмаркінг, реінжиніринг, використання моделей оцінки якості роботи (наприклад, тотальне управління якістю, ISO-9000, формування «робочих мереж», функціональний аналіз, менеджмент-аудит тощо) [6, с. 277].

Одним 3 найперспективніших методів внутрішнього оцінювання ефективності поліцейської діяльності, на нашу думку, є бенчмаркінг.

Бенчмаркінг на сьогодні застосовується в багатьох сферах. Стверджувати, що бенчмаркінг безпосередньо є методом оцінювання діяльності, немає підстав, оскільки його 
сутність полягає в тому, що визначається певний еталон діяльності, якому повинна відповідати діяльність, що оцінюється, і визначається, наскільки вона відповідає еталону.

Наприклад, для оцінювання ефективності поліцейської діяльності його можна застосовувати так. Серед територіальних підрозділів поліції у ході оцінки їхньої діяльності визначається еталонна (найбільш ефективна) діяльність, з'ясовуються іï показники та дії, процеси, які до них призвели. Після чого діяльність інших підрозділів повинна бути спрямована на досягнення саме таких результатів. І. С. Педак зазначає: «У центрі уваги бенчмаркінгу - запитання: чому інші працюють успішніше, ніж ми? Основний зміст і мета бенчмаркінгу полягає в ідентифікації відмінностей з порівнювальним аналогом (еталоном), визначенні причин цих відмінностей та виявленні можливостей щодо вдосконалення об'єктів бенчмаркінгу» [7, с. 53].

Слід зауважити, що нині метод бенчмаркінгу активно застосовується для аналізу ефективності правоохоронних органів США. 3 цією метою навіть створено спеціальний Портал порівняльного аналізу та аналізу ефективності правоохоронних органів [8]. Портал $\epsilon$ ресурсом для порівняльного аналізу 3 аналогічними агентствами і $€$ безкоштовним для користування.

Крім того, у зарубіжній практиці активно використовується метод збалансованої системи показників, запозичений із корпоративного управління. Збалансована система показників $є$ системою стратегічного менеджменту, заснованою на певних показниках, яка дозволяє узгодити діяльність організації з ії стратегією та здійснювати моніторинг досягнення стратегічних цілей. Для оцінки поліції у цій системі пропонується оцінювати такі аспекти діяльності:

- зниження рівня віктимізації;

- $\quad$ притягнення правопорушників до відповідальності;

- $\quad$ зниження відчуття страху та підвищення персональної безпеки;

- забезпечення безпеки в публічних місцях (включаючи безпеку дорожнього

pyxy);

- $\quad$ чесне, ефективне та доцільне використання фінансових ресурсів;

- $\quad$ чесне, ефективне та доцільне застосування засобів впливу;

- $\quad$ задоволення потреб споживачів поліцейських послуг [9, с. 28-29].

Зазначимо, що найбільш поширеними альтернативними джерелами інформації для оцінки ефективності діяльності поліції, що застосовуються під час відомчого оцінювання, є:

1) анкетування працівників поліції - ця методика дає змогу оцінити моральнопсихологічний стан співробітників у підрозділі, виявити проблеми з управлінням тощо;

2) пряме спостереження передбачає дослідження спеціально підготовленими спостерігачами окремих аспектів роботи поліції або ії наслідків (наприклад, спостереження за контактами поліцейських 3 громадянами в повсякденних ситуаціях, станом законності у проблемних районах міста тощо). Цей метод уважається ефективним для незалежної оцінки роботи поліції, однак, ураховуючи необхідність спеціальної підготовки персоналу, є достатньо затратним;

3) метод симуляцій, на відміну від попереднього методу, характеризується тим, що дослідники не є пасивними спостерігачами, а симулюють певні типові ситуації (наприклад звернення до поліції з повідомленням про злочин). Проте зазначений метод залишається суперечливим, особливо коли йде мова про симуляції, що схиляють поліцейських до незаконних дій [5, с. 18-19].

Варто наголосити, що відомче оцінювання ефективності поліцейської діяльності може проводитися і щодо конкретних працівників поліції. Що ж стосується методів оцінювання ефективності поліцейської діяльності окремих співробітників поліції, то вони значно відрізняються від методів загальної оцінки.

Найбільш розповсюдженим методом так званого персонального оцінювання ефективності поліцейської діяльності є атестація, щорічне оцінювання, піврічне, квартальне та щоденне оцінювання [10, с. 273]. 
В. Г. Залужний здійснює класифікацію методик оцінювання службової діяльності поліцейських залежно від мети та визначає такі види:

1) ті, що застосовуються під час оцінювання поліцейських громадськістю (оцінка рівня довіри населення до діяльності поліції), тобто сукупність способів та методів, серед яких: а) спостереження; б) опитування; в) вільна коефіцієнтна оцінка;

2) ті, що застосовуються під час відомчого оцінювання, передбачають використання таких методів, як: а) співбесіда; б) моніторинг; в) описовий; г) матричний; г) стандартних оцінок; д) аналіз конкретних ситуацій; е) документальний; є) тестування; ж) заданої бальної оцінки; з) градації [4, с. 16-17].

На сьогодні в розпорядженні керівників поліції перебувають як традиційні: анкетування (самооцінка), інтерв'ю (співбесіда), групова дискусія, аналіз документів, тестування, метод експертних оцінок, спостереження тощо [11, с. 228], так і новітні методи оцінювання персоналу: ділова гра, самозвіт (виступ), метод комітетів, метод незалежних суддів тощо [12, с. 318-319].

Поряд із традиційними для поліцейської системи методами персонального оцінювання ефективності поліцейської діяльності, на нашу думку, сьогодні доцільно застосовувати методи оцінки персоналу, що вдало апробовані та реалізуються в управлінні, недержавних структурах, які є достатньо різноманітними.

У науковій літературі [13; 14, с. 46-50; 15] виділяють такі види методів оцінки персоналу, які також можуть бути прийнятними і для персоналу Національної поліції:

- традиційні методи (біографічний метод; метод заданої бальної оцінки; ранжування; метод попарних порівнянь; метод еталону; метод графічного профілю; метод за результатами);

сучасні методи (метод «360 людських ресурсів; метод управління цілями; метод оцінки за ключовими показниками ефективності діяльності).

Безумовним є те, що використання зазначених методів потребує спеціальних знань суб'єктів, які їх застосовують. Саме тому одним із головних завдань сучасної системи управління Національною поліцією повинно бути визначено підготовку управлінських кадрів, здатних застосовувати сучасні методи оцінки персоналу.

Щодо громадського оцінювання ефективності поліцейської діяльності, то для його реалізації використовують інші методи. Аналіз змісту Порядку проведення оцінки рівня довіри населення до Національної поліції [16] свідчить про те, що незалежна соціологічна служба проводить оцінку у формі опитувань. У свою чергу, вони можуть здійснюватися різними методами.

Слід зазначити, що серед багатьох фахівців, особливо практиків, поширені песимістичні погляди на здатність «непрофесіоналів» об'єктивно оцінити як стан правопорядку, так і рівень ефективності діяльності поліцейської системи. Причина цього побоювання підміни критеріїв, які обов'язково повинні включати одиниці виміру ефективності й результативності такої діяльності. На думку деяких учених, використання тільки методу соціологічних опитувань або іншого моніторингу, ймовірніше, відображатиме загальні тенденції в суспільстві, ніж надасть якісну або кількісну оцінку поліцейської діяльності. Такий метод насамперед спрямований визначити рівень соціального рейтингу, іміджу системи, який не завжди залежить від ефективності або результативності поліцейської діяльності [17].

Наголосимо, що найбільш розповсюдженим методом громадського оцінювання ефективності поліцейської діяльності вважається метод соціологічного опитування, який $є$ «методом збирання інформації за допомогою постановки запитань певній групі людей (респондентів), відібраних за певним принципом - так, щоб ця відібрана сукупність за основними параметрами репрезентувала генеральну сукупність - тобто ту спільноту, на яку надалі поширюватимуться висновки опитування» [18, с. 7]. 
Безумовно, метод соціологічних опитувань має значний потенціал. Природно, що його слід застосовувати у такий спосіб, щоб максимально позбавитися від можливого безпосереднього втручання 3 боку персоналу Національної поліції, 3 огляду на це законодавець поклав його реалізацію на незалежні соціологічні служби.

Ще одним розповсюдженим методом є метод особистого інтерв’ю (face-to-face, або $\mathrm{F} 2 \mathrm{~F}$ ), який є одним із найдавніших і достатньо гнучким методом опитування. У цьому методі збору соціологічної інформації інтерв'юер опитує респондентів на основі заздалегідь розробленої анкети. Цей метод охоплює всю вибіркову сукупність, а також забезпечує максимальну взаємодію та спілкування між респондентом та інтерв'юером. Інтерв'ю F2F часто асоціюється 3 високою якістю даних та багатьма дослідниками розглядається як найкращий метод збору даних для значної кількості тем опитувань. Однак в останні десятиліття ця точка зору почала спростовуватися переважно через помилки вимірювання, які пов'язані із сенситивними тематиками досліджень. Але список тем збільшується у зв'язку з негативним впливом інтерв'юера, що може виникнути в процесі опитування [19, с. 189].

Доцільно підкреслити, що за допомогою зазначеного методу Харківським інститутом соціальних досліджень у 2018 році було проведено соціологічне опитування 19500 респондентів в Україні щодо оцінки діяльності Національної поліції, яке спрямовувалося на вирішення таких завдань:

- $\quad$ вивчити й надати суспільству та керівництву Національної поліції України чітке уявлення про те, як населення країни сприймає поліцію, яким є рівень довіри до неї;

- $\quad$ 3'ясувати, якими є основні показники успішності поліції в країні та регіонах;

- $\quad$ запропонувати доповнення до наявної системи оцінювання рівня злочинності та діяльності поліції, щоб зробити ії більш об'єктивною [20, с. 7].

Згаданий вище метод дослідження було застосовано і для оцінки рівня довіри населення до поліції у 2020 році [21].

На думку А. П. Казанжи, метод face-to-face має низку переваг, пов'язаних із можливістю проведення складних інтерв'ю та підвищення якості зібраних даних. Проте водночас найбільш серйозною проблемою цього методу збору даних $є$ значні матеріальні витрати, додаткові потенційні відхилення у відповідях, обумовлені впливом інтерв'юера та фальсифікаціями інтерв'ю [22, с. 76].

Із розвитком інтернет-технологій останнім часом доволі розповсюдженим є метод інтернет-опитування. До переваг використання такого кількісного методу збору соціологічної інформації належать:

- $\quad$ висока швидкість збору даних;

- $\quad$ відсутність впливу інтерв’юера - у відповідях респондентів рідше трапляються соціально бажані відповіді. Зокрема, респонденти на відкриті питання дають більш щирі, детальні та розгорнуті відповіді, ніж під час традиційного анкетування, а тому інтернетдослідження дозволяють отримати достатньо повну та змістовну інформацію;

- $\quad$ широта охоплення предмета дослідження - інтернет-мережа дає можливість вивчати приватні та закриті для публічного обговорення теми (більшість людей не погодилася б обговорювати такі теми в особистому інтерв’ю);

- $\quad$ організаційна гнучкість - респондент сам обирає зручний для нього час і місце заповнення анкети;

- строга логіка опитування - зберігається чіткість переходів від питання до питання. Наступне запитання не може бути поставленим, якщо не отримана відповідь на попереднє;

- $\quad$ використання більш складних опитувальників з аудіо- чи відеоматеріалами та графічними зображеннями [22, с. 77-78].

На сьогодні такий метод оцінювання рівня довіри населення до поліції активно використовується компанією ТОВ «Тейлор Нельсон Софрез Україна» (Kantar Україна) представником світового лідера в галузі маркетингових досліджень - компанії «Kantar», яка 3 
2015 року в межах дослідження Kantar online TRACK проводить регулярне вимірювання рівня довіри до різних інституцій та якості їхньої роботи, включно з поліцією [23].

Висновки. Отже, підсумовуючи, зазначимо, що сучасна система методів оцінювання ефективності поліцейської діяльності повинна складатися з традиційних методів, характерних для діяльності поліції, та нетрадиційних, запроваджених з інших сфер. До того ж слід зауважити, що не існує універсальних методів оцінювання, їх застосування повинно здійснюватися комплексно з урахуванням різних обставин: виду оцінювання, його мети, об'єкта оцінювання, суб'єктів, що залучаються до оцінювання, та їх навичок у використанні конкретних методів, наявних ресурсів тощо. На сьогодні актуальним питанням є застосування під час оцінки ефективності поліцейської діяльності методів (методик), що використовуються в недержавному секторі для оцінювання ефективності діяльності різних установ, підприємств, організацій, а також методи оцінки персоналу, що вдало апробовані та реалізуються в управлінні, недержавних структурах, які є достатньо різноманітними.

\section{Список використаних джерел}

1. Організація діяльності міліції громадської безпеки : навчальний посібник / кол. авт.; кер. д-р юрид. наук, проф., засл. юрист України О. В. Негодченко. Київ : МВС України, 2010. 148 c.

2. Основи управління в органах внутрішніх справ : навчальний посібник / О. М. Бандурка, В. М. Бевзенко, Р. А. Калюжний та ін. Харків : ХНУВС, 2011. 591 с.

3. Батраченко О. В. Удосконалення системи оцінювання ефективності забезпечення Національною поліцією України публічної безпеки та порядку. Право.иа. 2016. № 1. С. 58-63.

4. Залужний В. Г. Оцінювання службової діяльності поліцейського в Україні: теорія, правове регулювання, практика : автореф. дис. ... канд. юрид. наук : 12.00 .07 / Національний університет «Одеська юридична академія». Одеса, 2019. 24 с.

5. Закордонний досвід оцінки ефективності поліцейської діяльності та перспективи його використання в Україні : наук.-метод. рекомендації / К. Л. Бугайчук, I. О. Святокум, В. В. Чумак. Харків : Харк. нац. ун-т внутр. справ, 2016. 52 с.

6. Олійник Д. Сучасні методи оцінки ефективності діяльності органів державного управління. Ефективність держсавного управління. 2013. Вип. 34. С. 275-283.

7. Педак I. С. Бенчмаркінг як механізм порівняльного аналізу та запорука майбутнього регіонів. Вчені записки ТНУ імені В.І. Вернадського. Серія «Державне управління». 2017. № 1. Том 28 (67). С. 52-56.

8. The Law Enforcement Benchmarking and Performance Analytics Portal. URL: https://www.theiacp.org/benchmarking (дата звернення: 21.03.2021).

9. Roberts, David J. Law Enforcement Tech Guide for Creating Performance Measures That Work: A Guide for Executives and Managers. Washington, D.C.: U.S. Department of Justice Office of Community Oriented Policing Services, 2006. 168 p.

10. Управління органами Національної поліції України : підручник / за заг. ред. дра юрид. наук, доц. В. В. Сокуренка. Харків : Стильна типографія, 2017. 580 с.

11. Крушельницька О. В., Мельничук Д. П. Управління персоналом : навчальний посібник. Київ : Кондор, 2003. 296 с.

12. Балабанова Л. В., Сардак О.В.Управління персоналом : підручник. Київ : Центр учбової літератури, 2011. 468 с.

13. Дідур К. М. Сучасні методи оцінки персоналу. Ефективна економіка: електронний журнал. 2011. № 1. URL: http://www.economy.nayka.com.ua/?op=1\&z=776 (дата звернення: 29.03.2021).

14. Миронова Л. Г. Сучасні методи оцінювання персоналу підприємств. Культура народов Причерноморья. 2011. № 214. С. 46-50. 
15. Григор'єва Н. О. Оцінка якості персоналу в системі ефективного управління. Сучасність, наука, час. Взаємодія та взаємовплив : матеріали VIII Міжнародної науковопрактичної інтернет-конференції (23-25 листопада 2011 р.) URL: http://intkonf.org/grigorevano-otsinka-yakostipersonalu (дата звернення: 29.03.2021).

16. Про затвердження Порядку проведення оцінки рівня довіри населення до Національної поліції : Постанова Кабінету Міністрів України від 07 лютого 2018 року № 58. Офічійний вісник Украӥни. 2018. № 16. Ст. 552.

17. Сердюк А. А. Моніторинг правоохоронної діяльності - перспективи відомчої соціології. URL: file:///C:/Users/1/Downloads/y1vnK9QYr7gIKrXFNnulY5GH5n6-ins\%20(2).pdf (дата звернення: 30.03.2021).

18. Опитування громадської думки : посібник для журналістів / укладачі: Ірина Бекешкіна, Юрій Горбань, Ірина Філіпчук. Київ : Фонд «Демократичні ініціативи» імені Ілька Кучеріва, 2020. 110 с.

19. Biemer, P.P. Introduction to Survey Quality. 2003. 404 p. URL: http://books.google.com.ua/books?id=Etcyd75g9SYC\&pg=PA1\&lpg=PA1\&dq=Introduction+to+S urvey+Quality\&source=bl\&ots=hl0_CuGFRu\&sig=k76BrcN9cYIUv7qsvxyfiQbzj4\&hl=en\&sa=X \&ei=a6cXUdjNIMrHtAb8q4GYAg\&ved=0CDIQ6AEwAjgK (дата звернення: 01.04.2021).

20. Кобзін Д., Щербань С., Коренева К., Черноусов А. Оцінка діяльності Національної поліції України за допомогою опитування громадської думки (національний звіт). Харків : Харківський інститут соціальних досліджень (ХІСД), 2019. 52 с.

21. Оцінка роботи Нацполіції в 2020 році: результати соціологічного дослідження. URL: https://ua.interfax.com.ua/news/blog/731177.html (дата звернення 18.03.2021).

22. Казанжи А. П. Поняття і значення «ефекту від методу» в «mixed-mode» дослідженнях. Актуальні проблеми соиіології, психології, педагогіки. 2015. № 2 (27). С. 73-81.

23. Сприйняття поліції та оцінка іï роботи. URL: https://ns-ua.com/news/spriynyattyapolitsiyi-ta-otsinka-yiyi-roboti (дата звернення: 01.04.2021).

\section{References}

1. Orhanizatsiia diialnosti militsii hromadskoi bezpeky [Organization of militia of public safety] : navchalnyi posibnyk / kol. avt.; ker. d-r yuryd. nauk, prof., zasl. yuryst Ukrainy O. V. Nehodchenko. Kyiv : MVS Ukrainy, 2010. 148 s. [in Ukrainian].

2. Osnovy upravlinnia v orhanakh vnutrishnikh sprav [Basics of management in internal affairs bodies] : navchalnyi posibnyk / O. M. Bandurka, V. M. Bevzenko, R. A. Kaliuzhnyi ta in. Kharkiv : KhNUVS, 2011. 591 s. [in Ukrainian].

3. Batrachenko, O. V. (2016). Udoskonalennia systemy otsiniuvannia efektyvnosti zabezpechennia Natsionalnoiu politsiieiu Ukrainy publichnoi bezpeky ta poriadku [Improvement of the system for assessing the development of the National Police of Ukraine Public Security and Procedure]. Pravo.ua. № 1. S. 58-63 [in Ukrainian].

4. Zaluzhnyi, V. H. (2019). Otsiniuvannia sluzhbovoi diialnosti politseiskoho v Ukraini: teoriia, pravove rehuliuvannia, praktyka [Assessment of police officer in Ukraine: theory, legal regulation, practice] : avtoref. dys. ... kand. yuryd. nauk : 12.00.07 / Natsionalnyi universytet «Odeska yurydychna akademiia». Odesa. 24 s. [in Ukrainian].

5. Zakordonnyi dosvid otsinky efektyvnosti politseiskoi diialnosti ta perspektyvy yoho vykorystannia v Ukraini [Foreign experience of assessing the effectiveness of police activity and prospects for its use in Ukraine] : nauk.-metod. rekomendatsii / K. L. Buhaichuk, I. O. Sviatokum, V. V. Chumak. Kharkiv : Khark. nats. un-t vnutr. sprav, 2016. 52 s. [in Ukrainian].

6. Oliinyk, D. (2013). Suchasni metody otsinky efektyvnosti diialnosti orhaniv derzhavnoho upravlinnia [Modern methods for assessing the effectiveness of public administration bodies]. Efektyvnist derzhavnoho upravlinnia. Vyp. 34. S. 275-283 [in Ukrainian].

7. Pedak, I. S. (2017). Benchmarkinh yak mekhanizm porivnialnoho analizu ta zaporuka maibutnoho rehioniv [Benchmarking as a mechanism of comparative analysis and the key to the 
future regions]. Vcheni zapysky TNU imeni V. I. Vernadskoho. Seriia «Derzhavne upravlinnia». № 1. Tom 28 (67). S. 52-56 [in Ukrainian].

8. The Law Enforcement Benchmarking and Performance Analytics Portal. URL: https://www.theiacp.org/benchmarking (data zvernennia: 21.03.2021).

9. Roberts, David J. Law Enforcement Tech Guide for Creating Performance Measures That Work: A Guide for Executives and Managers. Washington, D.C.: U.S. Department of Justice Office of Community Oriented Policing Services, 2006. 168 p.

10. Upravlinnia orhanamy Natsionalnoi politsii Ukrainy [Management of the National Police Authorities of Ukraine] : pidruchnyk / za zah. red. d-ra yuryd. nauk, dots. V. V. Sokurenka. Kharkiv : Stylna typohrafiia, 2017. 580 s. [in Ukrainian].

11. Krushelnytska, O. V., Melnychuk, D. P. (2003). Upravlinnia personalom [Human resource management] : navchalnyi posibnyk. Kyiv : Kondor. 296 s. [in Ukrainian].

12. Balabanova, L. V., Sardak, O. V. (2011). Upravlinnia personalom [Human resource management] : pidruchnyk. Kyiv : Tsentr uchbovoi literatury. 468 s. [in Ukrainian].

13. Didur, K. M. (2011). Suchasni metody otsinky personalu [Modern methods of personnel evaluation]. Efektyvna ekonomika: elektronnyi zhurnal. № 1. URL: http://www.economy.nayka.com.ua/?op=1\&z=776 (data zvernennia: 29.03.2021) [in Ukrainian].

14. Myronova, L. H. (2011). Suchasni metody otsiniuvannia personalu pidpryiemstv [Modern methods of evaluation of personnel of enterprises]. Kultura narodov Prychernomoria. № 214. S. 46-50 [in Ukrainian].

15. Hryhorieva, N. O. (2011). Otsinka yakosti personalu v systemi efektyvnoho upravlinnia [Assessment of the quality of personnel in the system of effective management]. Suchasnist, nauka, chas. Vzaiemodiia ta vzaiemovplyv: materialy VIII Mizhnarodnoi naukovopraktychnoi internet-konferentsii (23-25 lystopada 2011 r.). URL: http://intkonf.org/grigoreva-nootsinka-yakostipersonalu (data zvernennia: 29.03.2021) [in Ukrainian].

16. Pro zatverdzhennia Poriadku provedennia otsinky rivnia doviry naselennia do Natsionalnoi politsii [On approval of the Procedure for assessing the level of public trust in the National Police] : Postanova Kabinetu Ministriv Ukrainy vid 07 liutoho 2018 roku № 58. Ofitsiinyi visnyk Ukrainy. 2018. № 16. St. 552 [in Ukrainian].

17. Serdiuk, A. A. Monitorynh pravookhoronnoi diialnosti - perspektyvy vidomchoi sotsiolohii [Monitoring of law enforcement activities - prospects of departmental sociology]. URL: file:///C:/Users/1/Downloads/y1 vnK9QYr7gIKrXFNnulY5GH5n6-in-s\%20(2).pdf (data zvernennia: 30.03.2021) [in Ukrainian].

18. Opytuvannia hpomadskoi dumky [Opinion poll] : posibnyk dlia zhurnalistiv / ukladachi: Iryna Bekeshkina, Yurii Horban, Iryna Filipchuk. Kyiv : Fond «Demokratychni initsiatyvy» imeni Ilka Kucheriva, 2020. 110 s. [in Ukrainian].

19. Biemer, P. P. Introduction to Survey Quality, 2003. 404 p. URL: http://books.google.com.ua/books?id=Etcyd75g9S YC\&pg=PA1\&lpg=PA1\&dq=Introduction+to+S urvey+Quality\&source=bl\&ots=hl0_CuGFRu\&sig=k76BrcN9cYIUv7qsvxyfiQbzj4\&hl=en\&sa=X \&ei=a6cXUdjNIMrHtAb8q4GYAg\&ved=0CDIQ6AEwAjgK (data zvernennia: 01.04.2021).

20. Kobzin, D., Shcherban, S., Koreneva, K., Chernousov, A. (2019). Otsinka diialnosti Natsionalnoi politsii Ukrainy za dopomohoiu opytuvannia hromadskoi dumky (natsionalnyi zvit) [Assessment of the Activities of the National Police of Ukraine through an opinion poll (national report)]. Kharkiv : Kharkivskyi instytut sotsialnykh doslidzhen (KhISD). 52 s. [in Ukrainian].

21. Otsinka roboty Natspolitsii v 2020 rotsi : rezultaty sotsiolohichnoho doslidzhennia [Assessment of the work of the National Police in 2020 : results of a sociological survey]. URL: https://ua.interfax.com.ua/news/blog/731177.html (data zvernennia 18.03.2021) [in Ukrainian].

22. Kazanzhy, A. P. (2015). Poniattia i znachennia «efektu vid metodu» v «mixed-mode» doslidzhenniakh [The concept and meaning of the «effect from the method» in «mixed-mode» studies]. Aktualni problemy sotsiolohii, psykholohii, pedahohiky. № 2 (27). S. 73-81 [in Ukrainian]. 
23. Spryiniattia politsii ta otsinka yii roboty [Perception of the police and assessment of its work]. URL: https://tns-ua.com/news/spriynyattya-politsiyi-ta-otsinka-yiyi-roboti (data zvernennia: 01.04.2021) [in Ukrainian].

\author{
Merdova Olha, \\ $\mathrm{PhD}$ in Law, Associate Professor \\ (Donetsk State University of Internal Affairs, Mariupol) \\ ORCID: https://orcid.org/0000-0003-0769-2364 \\ Filipenko Anastasia, \\ Master's degree \\ (Donetsk State University of Internal Affairs, Mariupol) \\ ORCID: https://orcid.org/0000-0003-2370-2497
}

\title{
METHODS OF EVALUATION OF POLICY EFFICIENCY
}

The article analyzes the existing methods of evaluating the effectiveness of policing. It is proved that the modern system of methods for evaluating the effectiveness of policing should consist of traditional methods specific to policing and non-traditional methods introduced from other areas. It is concluded that the current issue is the use in assessing the effectiveness of policing methods (techniques) used in the private sector to assess the effectiveness of various institutions, enterprises, organizations, as well as methods of evaluating staff, successfully tested and implemented in management, nongovernmental structures, which are quite diverse. Today, the performance of the police is a necessary tool in the management industry. We see the application of benchmarking in the system of evaluating the effectiveness of police activities as promising, and the biographical method for personnel evaluation; the method of a given score; ranking; method of pairwise comparisons; standard method; graphic profile method; method by results; method «360 certification»; assessment center method; human resources analysis; goal management method; method of evaluation of key performance indicators. The authors emphasize that the use of these methods requires special knowledge of the subjects who use them, which is why one of the main tasks of the modern management system of the National Police should be to train managers capable of using modern methods of personnel evaluation. It is worth emphasizing that the departmental evaluation of efficiency of police activity can be carried out in relation to specific police officers. As for methods for evaluation of efficiency of police activity of individual police officers, they are significantly different from the methods of general assessment. It is concluded that there are no universal methods of evaluation, they, as well as criteria, evaluation should be carried out comprehensively taking into account various circumstances: the type of evaluation, its purpose, the object of evaluation, the subjects involved in evaluation, and their skills in the application of specific methods, available resources, etc.

Key words: police; policing; performance evaluation; evaluation methods.

Надіслано до редколегії 11.05.2021

Рекомендовано до публікації 18.05.2021 


\section{ВИМОГИ ЩОДО ОФОРМЛЕННЯ ТА ПОДАННЯ СТАТЕЙ ДО ЗБІРНИКА НАУКОВИХ ПРАЦЬ «ПРАВОВИЙ ЧАСОПИС ДОНБАСУ»}

\section{1. Загальні положення}

Для публікації у збірнику наукових праць автори подають результати особистих (або в співавторстві) оригінальних наукових і науково-практичних досліджень, які не були раніше опубліковані та не надіслані до публікації в інші видання, підготовлені українськоюмовою та відповідають установленим вимогам до кваліфікованих наукових праць.

У статті повинно бути відображено наукову новизну в галузі досліджень.

Редколегія журналу залишає за собою право відхиляти ті статті, що не відповідають його тематиці, технічним та етичним стандартам; повертати на доопрацювання та редагувати їх.

2. Структура наукових статей:

- постановка проблеми в загальному вигляді та іï зв'язок із важливими науковими чи практичними завданнями;

- $\quad$ аналіз останніх досліджень і публікацій, у яких започатковано розв'язання визначеної проблеми і які взято за основу автором; під час опису вкладу попередників у розкриття тематики статті не допускається лише перелік їхніх прізвищ, без вказівки на не вирішені ними раніше частини загальної проблеми та причинно-наслідковий зв'язок їхніх робіт із метоюстатті. Достатньо залишити 3-4 прізвища попередніх дослідників (прізвища згадувати в алфавітному порядку), але стисло зазначити внесок кожного, зробивши посилання у квадратних дужках; бажано включити й аналіз наукових робіт 2-3 іноземних авторів за тематикою статті;

- формування цілей статті (постановка завдання);

- $\quad$ виклад основного матеріалу з повним обгрунтуванням отриманих наукових результатів;

- $\quad$ висновки на підставі проведеного дослідження та перспективи подальших розвідок у цьому напрямку.

3. Вимоги до оформлення тексту наукових статей:

- $\quad$ стаття готується в текстовому редакторі MS Word, шрифт - Times New Roman (основний текст статті розміром 14 pt 3 інтервалом 1,5), без переносів;

- рекомендований обсяг тексту статті (без списку використаних джерел та анотацій) - 8-10 сторінок;

- $\quad$ перший рядок (ліворуч) - УДК статті;

- $\quad$ другий рядок (праворуч) - прізвище, ім'я, ім'я по батькові автора (співавторів) (шрифт напівжирний);

- $\quad$ третій (за необхідності й четвертий) рядок (праворуч) - науковий ступінь, учене звання, почесне звання, членство в НАН України, НАПрН України чи інших галузевих АН (за наявності), місце роботи автора (співавторів);

- $\quad$ на наступному рядку - інформація про ORCID автора;

- $\quad$ н $\quad$ нижче (посередині рядка) назва статті великими літерами (шрифтнапівжирний);

- $\quad$ д далі - анотація (500 друкованих знаків) та ключові слова (4-8 слів) українською

мовою;

- $\quad$ через інтервал - текст статті;

- $\quad$ посилання на використані джерела робиться у квадратних дужках із зазначенням номера джерела та конкретних сторінок, наприклад [1, с. 25-26], а самі назви джерел наводяться в розділі «Список використанихджерел» у порядку згадування в тексті;

- $\quad$ бібліографічний опис джерел подається відповідно до ДСТУ 8302:2015;

- після розділу «Список використаних джерел» оформлюється References (за міжнародним стандартом APA). Онлайн-транслітерація українськомовних джерел 
здійснюється відповідно до ukrlit.org/transliteratsiia, онлайн-транслітерація російськомовних джерел - відповідно до translit-online.ru.

У кожному транслітерованому джерелі у квадратних дужках подається переклад на англійську мову найбільш значущих фрагментів бібліографічного опису (назва матеріалу, назва періодичного видання, нормативно-правового джерела тощо). Не допускається використання символів «/» та римських цифр (замінити на арабські). Не українсько- та не російськомовні джерела не транслітеруються. Наприкінці бібліографічного опису кожного джерела у квадратних дужках позначається мова, на якій воно надруковано - [in Ukrainian] чи [in Russian];

- якщо описувана публікація має DOI (система DOI $є$ міжнародним ISO стандартом), цей ідентифікатор обов'язково вказується в References (наприкінці), оскільки саме він $\epsilon$ найбільш точним джерелом інформації про статтю і за ним здійснюється зв'язка «посилання - публікація»;

- $\quad$ наприкінці подається розширена англомовна анотація (не менше 1800 знаків) та ключові слова (4-8 слів). Відомості про авторів статті та їі назва також оформлюються англійською мовою (прізвище та ім'я автора - за зразком написання в паспорті для виїзду за кордон; назва підрозділу та організації має точно відповідати їхній офіційній назві англійською мовою).

Звертаємо Вашу увагу: розширену англомовну анотацію має бути засвідчено підписом фахівця (підпис, ПІБ та контактні дані перекладача).

\section{4. Вимоги щодо подання матеріалів у редакцію:}

- $\quad$ електронний варіант статті, довідку про автора, фото автора та розширену англомовну анотацію необхідно надіслати на адресу: dui55@ukr.net;

- $\quad$ у довідці про автора (співавторів) зазначити ПІБ (повністю); науковий ступінь; учене звання; членство в НАН України, НАПрН України чи інших галузевих АН (за наявності); місце роботи й посаду; інформацію про ORCID автора; контактний номер телефону; електронну пошту; відділення «Нової пошти» чи «Укрпошти», на яке необхідно надіслати примірник збірника; розділ збірника, у який доцільно розмістити статтю;

- $\quad$ фото автора у форматі jpg;

- якщо автор не має наукового ступеня, необхідно подати рецензію наукового керівника.

Відповідальність за достовірність поданої інформації, наведених цитат, прізвищ, оформлення списку використаних джерел покладається на авторів.

Усі матеріали підлягають обов'язковому внутрішньому сліпому рецензуванню членами редакційної колегії.

Електронна копія збірника безоплатно розміщується у відкритому доступі на сайті Національної бібліотеки України імені В. І. Вернадського НАН України у розділі «Наукова періодика України», а також на вебсайті видання за адресою: https://ljd.dli.donetsk.ua/ljdarchive.

Вимоги щодо оформлення статей та References розміщено за посиланням: https://ljd.dli.donetsk.ua.

Редакційна колегія збірника 


\section{ВІДОМОСТІ ПРО АВТОРІВ}

\section{Барган Сергій Сергійович,}

магістр права

sergiusbargan@gmail.com

(Донецький державний університет внутрішніх справ, м. Кривий Ріг)

\section{Воробей Андрій Олегович,}

заступник начальника сектору дізнання

A.Vorobey11@ukr.net

(Маріупольське районне управління поліиії ГУНП в Донецькій області, м. Маріуполь)

\section{Голобутовський Роман Зіновійович,} доктор юридичних наук larysa-nalyvaiko@ukr.net

(Дніпропетровський державний університет внутрішніх справ, м. Дніпро)

\section{Данилевська Юлія Олександрівна,}

кандидат юридичних наук, старший науковий співробітник

yuladan83@gmail.com

(Донецький державний університет внутрішніх справ, м. Маріуполь)

\section{Данилевський Андрій Олександрович,}

кандидат юридичних наук, доцент

danilevsky4@gmail.com

(Донеиький державний університет внутрішніх справ, м. Маріуполь)

\section{Дацюк Тетяна Кузьмівна,}

кандидат історичних наук, доцент

t.k.datsiuk@gmail.com

(Донеиький державний університет внутрішніх справ, м. Кривий Ріг)

\section{Демчишин Дмитро Анатолійович,}

викладач

demdimdem@gmail.com

(Донеиький державний університет внутрішніх справ, м. Маріуполь)

\section{Спринцев Пилип Сергійович,}

кандидат юридичних наук, доцент

efs8111@ukr.net

(Донецький державний університет внутрішніх справ, м. Кривий Ріг)

\section{Ковальов Костянтин Миколайович,}

заступник директора

tedp@ukr.net

(Державний науково-дослідний експертно-криміналістичний центр МВС Украӥни, м. Київ)

\section{Коміссарова Наталя Олександрівна,}

кандидат юридичних наук, доцент

kominata@ukr.net

(Донецький державний університет внутрішніх справ, м. Кривий Ріг) 
Коміссаров Микола Леонідович, кандидат юридичних наук, доцент nikkorov@ukr.net (Донеиький державний університет внутрішніх справ, м. Кривий Ріг)

Кубарсв Іван Володимирович, кандидат юридичних наук, доцент kurt76@ukr.net (Донецький державний університет внутрішніх справ, м. Кривий Ріг)

\section{Курнасва Катерина Генійовна,}

ад'юнкт

katya.kurnaieva@gmail.com

(Донеиький державний університет внутрішніх справ, м. Маріуполь)

Макарчук Віталій Володимирович, кандидат юридичних наук makarchuk.v@btsau.edu.ua (Білочерківський начіональний аграрний університет, м. Біла Церква)

\section{Мердова Ольга Миколаївна,} кандидат юридичних наук, доцент olga.merdova@ukr.net (Донеиький державний університет внутрішніх справ, м. Маріуполь)

\section{Назимко Єгор Сергійович,} доктор юридичних наук, старший науковий співробітник nazumuch@ukr.net (Донецький державний університет внутрішніх справ, м. Маріуполь)

\section{Пересада Ольга Михайлівна,} кандидат юридичних наук, доцент peresada.olga@gmail.com (Донеиький державний університет внутрішніх справ, м. Маріуполь)

\section{Савчук Марина Анатоліївна,} викладач advokat.sma@gmail.com (Донецький державний університет внутрішніх справ, м. Кривий Ріг)

\section{Сальнікова Наталія Валеріївна,} кандидат історичних наук natalisalnikova2601@gmail.com (Донецький державний університет внутрішніх справ, м. Маріуполь)

\section{Семенишина-Фіголь Богдана Миколаївна,} здобувач danusy7777@gmail.com (Донецький державний університет внутрішніх справ, м. Маріуполь) 


\section{Синюшко Дмитро Андрійович,}

аспірант

boss2k2003@ukr.net

(Національна академія внутрішніх справ, м. Київ)

\section{Смирнов Максим Іванович,}

кандидат юридичних наук, доцент

smirnov_maksim@ukr.net

(Начіональний університет «Одеська юридична академія», м. Одеса)

\section{Терехова Тамара Олексіївна,}

аспірантка

terekhova879@gmail.com

(Національний юридичний університет імені Ярослава Мудрого, м. Харків)

\section{Тіточка Тетяна Ігорівна,}

кандидатка юридичних наук

tatianaponomarova@ukr.net

(Донецький державний університет внутрішніх справ, м. Маріуполь)

\section{Уткіна Галина Анатоліївна,}

кандидат економічних наук, доцент

utkina.ga@gmail.com

(Донецький державний університет внутрішніх справ, м. Кривий Ріг)

\section{Філіпенко Анастасія Юріївна,}

здобувач освітнього ступеня «магістр»

nastyafilipenko88@gmail.com

(Донецький державний університет внутрішніх справ, м. Маріуполь)

\section{Цуркан Олексій Петрович,}

кандидат юридичних наук

curivan69@gmail.com

(Донецький державний університет внутрішніх справ, м. Кривий Ріг)

\section{Червінчук Андрій Васильович,}

кандидат юридичних наук

chervin_a@ukr.net

(Донеиький державний університет внутрішніх справ, м. Кривий Ріг)

\section{Шапарь Артем Олександрович,}

кандидат юридичних наук

shapar-artem@ukr.net

(Донеиький державний університет внутрішніх справ, м. Кривий Ріг)

\section{Шеховцова Вікторія Володимирівна,}

кандидат економічних наук

schech_vita@ukr.net

(Донецький державний університет внутрішніх справ, м. Кривий Ріг)

\section{Щербіна Артем Валентинович,}

аспірант

535475@ukr.net

(Донецький державний університет внутрішніх справ, м. Маріуполь) 


\section{Наукове видання ПРАВОВИЙ ЧАСОПИС ДОНБАСУ № 2 (75) 2021}

Відповідальна за випуск: Оксана Рутвян Редактори: Ольга Пластун, Юлія Ухальська Дизайн обкладинки: ВД «Дакор»

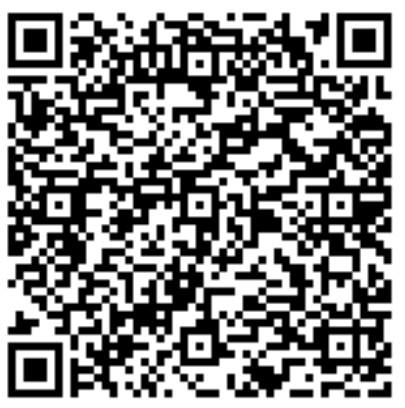

Видавеиь

Донецький державний університет внутрішніх справ

Донецька обл., м. Маріуполь, просп. Луніна, 89 https://dnuvs.in.ua/

Свідоцтво про державну реєстрацію друкованого засобу масової інформації КВ № 22764-12661 ПР від 30.05.2017

Підп. до друку 28.05.2021. Формат 60x84 1/8. Друк офсет.

Папір офсет. Ум. друк. арк. 27. Обл.-вид. арк. 16,9.

Наклад 60 прим. Зам. № 29\19

Виготовлювач

ФОП Маринченко С. В., вул. Героїв АТО, 81-А, оф. 109, м. Кривий Ріг Свідоцтво про державну реєстрацію ВО2 № 030567 від 19.01.2007 p. 